
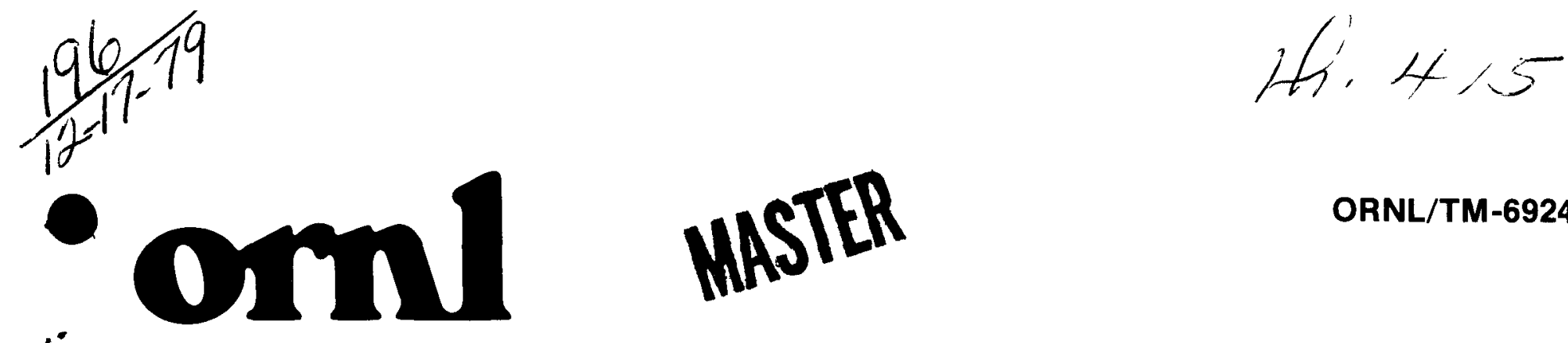

ORNL/TM-6924

\title{
Gel-Sphere-Pac Reactor Fuel Fabrication and Its Application to a Variety of Fuels
}
A. R. Olsen
R. R. Judkins

OPERATED BY

UNION CARBIDE CORPORATION FOR THE UNITED STATES DEPARTMENT OF ENERGY 


\section{Printed in the United States of America. Available from National Technical Information Service \\ U.S. Department of Commerce \\ 5285 Port Royal Road, Springfield, Virginia 22161 \\ NTIS price codes-Printed Copy: Al4 Microfiche A01}

This report was prepared as an account of work sponsored by an agency of the United States Government Nelther the United States nor any agency thereof, nor any of their employees, makes any warranty, expressed or implied, or assumes any legal liability or responsibility for any third party's use or the results of such use of any information, apparatus, product or process disclosed in this report. or represents that its use by such thırd party would not infringe privately owned rights 


\section{DISCLAIMER}

This report was prepared as an account of work sponsored by an agency of the United States Government. Neither the United States Government nor any agency Thereof, nor any of their employees, makes any warranty, express or implied, or assumes any legal liability or responsibility for the accuracy, completeness, or usefulness of any information, apparatus, product, or process disclosed, or represents that its use would not infringe privately owned rights. Reference herein to any specific commercial product, process, or service by trade name, trademark, manufacturer, or otherwise does not necessarily constitute or imply its endorsement, recommendation, or favoring by the United States Government or any agency thereof. The views and opinions of authors expressed herein do not necessarily state or reflect those of the United States Government or any agency thereof. 


\section{DISCLAIMER}

Portions of this document may be illegible in electronic image products. Images are produced from the best available original document. 
ORNL/TM-6924

Distribution

Categories UC-77,

$79 \mathrm{~b},-\mathrm{c}$, and 83

Contract No. W-7405-eng-26

METALS AND CERAMICS DIVISION

\begin{abstract}
GEL-SPHERE-PAC REACTOR FUEL FABRICATION AND
ITS APPLICATION TO A VARIETY OF FUELS
\end{abstract}

Compiled by A. R. Olsen and R. R. Judkins

Contributors
A. J. Caputo
R. R. Judkins
R. E. Norman
A. R. O1sen

R. R. Suchomel

Date Published: December 1979

NOTICE This document contains information of a preliminary nature. It is subject to revision or correction and therefore does not represent a final report.

Research sponsored by the Nuclear Power and Development Division, U.S. Department of Energy under contract W-7405-eng-26 with the Union Carbide Corporation and Purchase Order 64357AG from Battelle-Pacific Northwest Laboratories.

\author{
OAK RIDGE NATIONAL LABORATORY \\ Oak Ridge, Tennessee 37830 \\ operated by \\ UNION CARBIDE CORPORATION \\ for the \\ DEPARTMENT OF ENERGY
}

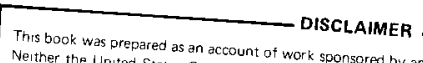

Ne ther the United States Government nor any agency thy an agency of the United States Governonent
warranty express or

completeness or or implied or assu mes agny legal tabul nor any of their employses makes any

represents that ts use winess of any intormation apoaratus or responsiblitity for the accuracy

commercial product process or serwinge privately owned rights Reterence process disclosed or

not necessarlly corstitute or imply its endore name tradernark manufacturer or to any specitic

States Government or any agency thereof The vement recommendation or favorno by the does 
The authors wish to acknowledge the assistance provided by many others in the preparation of this report: M. A. Patrizio and

H. R. Livesey for the preparation of the drawings; R. L. Beatty, E. S. Bomar, Jr., and L. Abraham for the many helpful comments provided in the review of this report; and especially the editing of the manuscript provided by S. Peterson and B. G. Ashdown and the efforts of M. R. Hill and the personnel in the Metals and Ceramics Division Reports office who prepared the manuscript for reproduction. 
ACKNOWLEDGMENTS . . . . . . . . . . . . . . . .

ABSTRACT . . . . . . . . . . . . . . . . . . . xiii

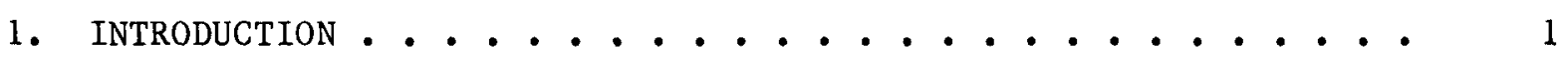

2. DEFINITION OF THE GEL-SPHERE-PAC LWR PLUTONIUM RECYCLE FUEL

FABRICATION PLANT ....................... 3

2.1 MAJOR ACTIVITIES . . . . . . . . . . . . . 3

2.2 Plant DESIGN CHARACTERISTICS . . . . . . . . . . 5

2.3 OPERATING PHILOSOPHY . . . . . . . . . . . . . 6

2.4 IN-PROCESS INVENTORY REQUIREMENTS . . . . . . . . . 7

3. FABRICATION PROCESSES ...................... 9

3.1 PRODUCT MANUFACTURE . . . . . . . . . . . . . . 9

3.1.1 Flowsheet and Process Descriptions........ 9

3.1.2 Product Control Processes . . . . . . . . 17

3.2 SCRAP AND WASTE PROCESSING AND DISPOSAL . . . . . . 18

3.2.1 Scrap Handling . . . . . . . . . . . 18

3.2.2 Waste Processing and Disposal ......... 18

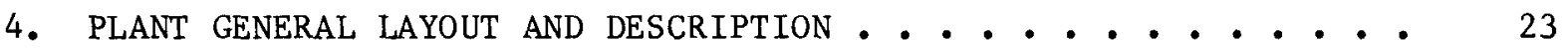

4.1 General LAYOUT . . . . . . . . . . . . . . 23

4.1.1 Site Perimeter ................ 23

4.1.2 Controlled Area . . . . . . . . . . . 23

4.1.3 Process Areas ............. 25

4.2 GENERAL DESCRIPTION . . . . . . . . . . . . 25

4.2.1 Operational Support Building . . . . . . . 25

4.2.2 Process Building . . . . . . . . . . 26

4.2.3 Fabrication Process Support Areas . . . . . . 30

4.2.4 Waste Treatment Building . . . . . . . . 31 


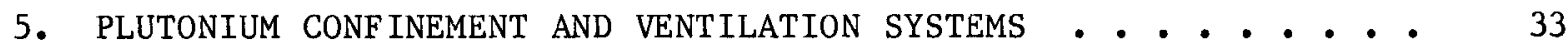

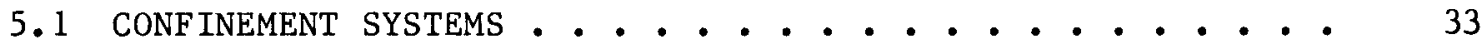

5.2 VEnTILATION SYSTEMS . . . . . . . . . . . 33

6. SAFETY AND PROTECTION MEASURES . . . . . . . . . . . . 37

6.1 PROTECTION AGAINST CRITICALITY . . . . . . . . . 37

6.1.1 Prevention ................ 37

6.1.2 Detection and Alarm ............ 37

6.1.3 Evacuation ....................... 37

6.2 DOSIMETRY . . . . . . . . . . . . . . . 38

6.2.1 Plant Design . . . . . . . . . . 38

6.2.2 Plant Monitoring . . . . . . . . . . 39

6.3 SAFETY AND LICENSABILITY . . . . . . . . . . . . . 39

6.4 ENVIRONMENTAL ASSESSMENT . . . . . . . . . . . 40

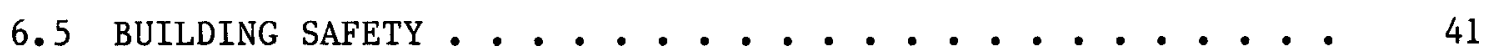

6.5.1 Prevention ................ 41

6.5.2 Fire Detection and Alarm Systems . . . . . . . 42

6.5.3 Fire Suppression Agents and Techniques ....... 43

6.6 SAFEGUARDS . . . . . . . . . . . . 43

6.6.1 Physical Protection System . . . . . . . . 44

6.6.2 Materials Measurement and Accountability System
(MMAS) . . . . . . . . . . . 45

6.6.3 System Structure .............. 46

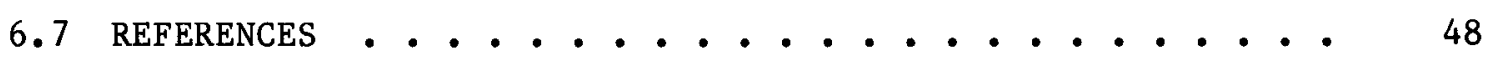

7. OPERATIONAL PERSONNEL AND ORGANIZATION OF THE PLANT . . • • • 49

8. GENERAL STATUS OF TECHNOLOGY . . . . . . . . . . . 51

8.1 TECHNOLOGY STATUS AND DEVELOPMENT REQUIREMENTS BY PROCESS

FUNCTIONS ...................... 
8.1.1 Receiving and Storage . . . . . . . . . 55

8.1.2 Fuel Production ............. 56

8.1.3 Fuel Rod Fabrication . . . . . . . . . 64

8.1.4 Fue1 Element Assembly . . . . . . . . . . 68

8.1.5 Scrap Handling . . . . . . . . . . 69

8.1.6 Waste Processing and Disposal ......... 70

8. 2 RESEARCH, DEVELOPMENT, AND DEMONSTRATION RESOURCE

REQUIREMENTS ESTIMATES ............... 71

8.3 REFERENCES . . . . . . . . . . . . 76

9. COMMERCIAL AND TECHNICAL FEASIBILITY OF VARIOUS REACTOR FUEL

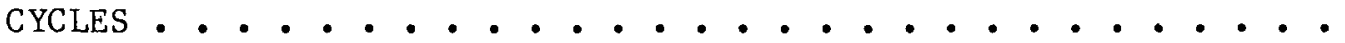

9.1 NASAP CASE $1.2-$ PWR- $\left({ }^{235} \mathrm{U}, \mathrm{U}\right) \mathrm{O}_{2}$ EXTENDED BURNUP

[PWR LEU(5) - MOD OT] . . . . . . . . . . 87

9.1.1 Fuel Cycle Description . . . . . . . . . 87

9.1.2 Applicability to Current Fuel Element Design . . . 87

9.1.3 Definition of Plant Production Requirements and

Design Capacity ...............

9.1.4 Estimates of Surge Storage Requirements, Scrap

Production Rates, and Processing Rates for

Functiona1 Steps . . . . . . . . . . • •

9.1.5 Analysis of Functional Technology Status, Research and Development Requirements, Cost, and Schedule..

9.1.6 Preliminary Cost Estimate for Construction and Operation of a Commercial-Scale Plant . . . . .

9.2 NASAP CASE 1.3 - PWR SPIKED (U, Pu)O 2 REFABRICATION

[PWR LEU(5)-Pu SPIKED RECYCLE] . . . . . . . . .

9.2.1 Fuel Cycle Description . . . . . . . . . 98

9.2.2 Applicability to Current Fuel Element Design . . . 98

9.2.3 Definition of Plant Production Requirements and Design Capacity ...............

9.2.4 Estimates of Surge Storage Requirements, Scrap Production Rates, and Processing Rates for Functional Steps . . . . . . . . . . . • 
9.2.5 Analysis of Functional Technology Status, Research and Development Requirements, Cost, and Schedule . .

9.2.6 Preliminary Cost Estimate for Construction and Operation of a Commercial-Scale Plant . . . . 103

9.3 NASAP CASE 1.4 - PWR $(233 \mathrm{U}, \mathrm{U}, \mathrm{Th}) \mathrm{O}_{2}$ FABRICATION AND REFABRICATION [PWR DU(3)-Th RECYCLE DU(3)] . . . . . . 108

9.3.1 Fuel Cycle Description . . . . . . . . . 108

9.3.2 Applicability to Current Fuel Element Design . . . 108

9.3.3 Definition of Plant Production Requirements and Design Capacity ...............

9.3.4 Estimates of Surge Storage-Requirements, Scrap Production Rates, and Processing Rates for

Functional Steps ...............

9.3.5 Analysis of Functional Technology Status, Research and Development Requirements, Cost, and Schedule •.

9.3.6 Preliminary Cost Estimate for Construction and Operation of a Commercial-Scale Plant . . . . .

9.4 NASAP CASE 1.5 - PWR ( $\mathrm{Pu}, \mathrm{U}) \mathrm{O}_{2}$ REFABRICATION [PWR-U-Pu] • • 118

9.4.1 Fuel Cycle Description . . . . . . . . . 118

9.4.2 Applicability to Current Fuel Element Design . • • 118

9.4.3 Definition of Plant Production Requirements and Design Capacity . . . . . . . . . . • •

9.4.4 Estimates of Surge Storage Requirements, Scrap Production Rates, and Processing Rates for

Functional Steps ...............

9.4.5 Analysis of Functional Technology Status, Research and Development Requirements, Cost, and Schedule . .

9.4.6 Preliminary Cost Estimate for Construction and Operation of a Commercial-Scale Plant ......

9.5 NASAP CASE $2.1-$ HWR $\left(235_{U}, U\right) O_{2}$ FABRICATION [HWR LEU(5)-OT)] . . . . . . . . . . . 128

9.5.1 Fuel Cycle Description . . . . . . . . . 128

9.5.2 Applicability to Current Fuel Element Design . . • 128 
vii

9.5.3 Definition of Plant Production Requirements and Design Capacity ..............

9.5.4 Estimates of Surge Storage Requirements, Scrap Production Rates, and Processing Rates for

Functional Steps ................

9.5.5 Analysis of Functional Technology Status, Research and Development Requirements, Cost, and Schedule..

9.5.6 Preliminary Cost Estimate for Construction and Operation of a Commercial-Scale Plant . . . . .

9.6 NASAP CASE 3.1.1 - LWBR MEU(5)-Th RECYCLE, PWR BACKFIT PREBREEDER

9.6.1 Fuel Cycle Description .............

9.6.2 Applicability to Current Fuel Element Design . . .

9.7 NASAP CASE 3.1.2 - LWBR HEU(3)-Th, RECYCLED U(3), ADVANCED BREEDER . • . . . . . . . . . . . . . . . . .

9.7.1 Fuel Cycle Description . . . . . . . . . 141

9.7.2 Applicability to Current Fuel Element Design . . . 141

9.7.3 Definition of Plant Production Requirements and Design Capacity ..............

9.7.4 Estimates of Surge Storage Requirements, Scrap Production Rates, and Processing Rates for Functional Steps ...............

9.7.5 Analysis of Functional Technology Status, Research and Development Requirements, Cost, and Schedule..

9.7.6 Preliminary Cost Estimate for Construction and Operation of a Commercial-Scale Plant . . . . .

9.8 NASAP CASE 3.2.1, LWBR MEU(5)-Th, PREBREEDER CONCEPT BASED ON TYPE I MODULES ...................

9.8.1 Fuel Cycle Description . . . . . . . . . 145

9.8.2 Applicability to Current Fuel Element Design . . • 145

9.9 NASAP CASE 3.2.2, LWBR HEU(3)-Th BREEDER CONCEPT BASED ON LWBR TYPE I MODULES . . . . . . . . . . . . . . . 
9.9.2 Applicability to Current Fuel Element Design ...

147

9.9.3 Definition of Plant Production Requirements and

Design Capacity . . . . . . . . . . . .

9.9.4 Estimates of Surge Storage Requirements, Scrap

Production Rates, and Processing Rates for

Functional Steps . . . . . . . . . 150

9.9.5 Analysis of Functional Technology Status, Research and Development Requirements, Cost, and Schedule.

9.9.6 Preliminary Cost Estimate for Construction and Operation of a Commercial-Scale Plant . . . . .

9.10 NASAP CASE 3.3.1, LWBR HEU(5), Th BACKF IT PREBREEDERS • • 153

9.10.1 Fuel Cycle Description . . . . . . . . 153

9.10.2 Applicability to Current Fuel E1ement Design . . . 153

9.10.3 Definition of Plant Production Requirements and Design Capacity . . . . . . . . . . . •

9.10.4 Estimates of Surge Storage Requirements, Scrap Production Rates, and Processing Rates for Functional Steps ............ 155

9.10.5 Analysis of Functional Technology Status, Research and Development Requirements, Cost, and Schedule.

9.10.6 Preliminary Cost Estimate for Construction and Operation of a Commercial-Scale Plant . . . . .

9.11 NASAP CASE 3.3.2, LWBR HEU(3)-Th/Th SEED BLANKET BREEDER • 164

9.11.1 Fuel Cycle Description ............ 164

9.11.2 Applicability to Current Fuel Element Design . . . 164

9.11.3 Definition of Plant Production Requirements and Design Capacity ................

9.11.4 Estimates of Surge Storage Requirements, Scrap Production Rates, and Processing Rates for Functional Steps ............ 167

9.11.5 Analysis of Functional Technology Status, Research and Development Requirements, Cost, and Schedule.

9.11.6 Preliminary Cost Estimate for Construction and Operation of a Commercial-Scale Plant ...... 
9.12 NASAP CASE 5.1, GCFR U(5)-Pu/Th RECYCLE . . . . . . 170

9.12.1 Fuel Cycle Description . . . . . . . . . 170

9.12.2 Applicability to Current Fuel Element Design . • 170

9.12.3 Definition of P1ant Production Requirements and Design Capacity ............. . 172

9.12.4 Estimates of Surge Storage Requirements, Scrap Production Rates, and Processing Rates for Functional Steps ............ 173

9.12.5 Analysis of Functional Technology Status, Research and Development Requirements, Cost, and Schedule.

9.12.6 Preliminary Cost Estimate for Construction and Operation of a Commercial-Scale Plant . . . . .

9.13 NASAP CASE 6.1, LMFBR U-Pu/U/U RECYCLE (GENERAL ELECTRIC REFERENCE )

9.13.1 Fuel Cycle Description . . . . . . . . . 182

9.13.2 Applicability to Current Fuel Element Design . . . 182

9.13.3 Definition of Plant Production Requirements and Design Capacity ................

9.13.4 Estimates of Surge Storage Requirements, Scrap Production Rates, and Processing Rates for Functional Steps ...............

9.13.5 Analysis of Functional Technology Status, Research and Development Requirements, Cost, and Schedule •

9.13.6 Preliminary Cost Estimate for Construction and Operation of a Commercial-Scale Plant ..... .

9.14 NASAP CASE 6.2.1, LMFBR U-Pu/U SPIKED RECYCLE (WESTINGHOUSE REFERENCE) - HETEROGENEOUS CORE DESIGN . . . .

9.14.1 Fuel Cycle Description .............. 194

9.14.2 Applicability to Current Fuel Element Design . . . 194

9.14.3 Definition of P1ant Production Requirements and Design Capacity ...............

9.14.4 Estimates of Surge Storage Requirements, Scrap Production Rates, and Processing Rates for Functional Steps . . . . . . . . . . . 
9.14.5 Analysis of Functional Technology Status, Research and Development Requirements, Cost, and Schedule.

9.14.6 Preliminary Cost Estimate for Construction and Operation of a Commercial-Scale Plant ...... 203

9.15 NASAP CASE 6.2.2, LMFBR U-Pu/U SPIKED RECYCLE (GENERAL ELECTRIC REFERENCE) HOMOGENEOUS CORE DESIGN . . . . . . 206

9.15.1 Fuel Cycle Description . . . . . . . . 206

9.15.2 Applicability to Current Fuel Element Design • • 207

9.15.3 Definition of Plant Production Requirements and Design Capacity . . . . . . . . . . 207

9.15.4 Estimates of Surge Storage Requirements, Scrap Production Rates, and Processing Rates for Functional Steps ...............

9.15.5 Analysis of Functional Technology Status, Research and Development Requirements, Cost, and Schedule • 209

9.15.6 Preliminary Cost Estimate for Construction and Operation of a Commercial-Scale Plant . . . . 215

9.16 NASAP CASE 6.3.1, LMFBR U-Pu/Th SPIKED RECYCLE, WESTINGHOUSE TRANSMUTER: HETEROGENEOUS CORE DESIGN • • • 218

9.16.1 Fuel Cycle Description ............. 218

9.16.2 Applicability to Current Fuel Element Design . . 219

9.16.3 Definition of P1ant Production Requirements and Design Capacity ................

9.16.4 Estimates of Surge Storage Requirements, Scrap Production Rates, and Processing Rates for Functional Steps ................

9.16.5 Analysis of Functional Technology Status, Research and Development Requirements, Cost, and Schedule.

9.16.6 Preliminary Cost Estimate for Construction and Operation of a Commercial-Scale Plant . . . . .

9.17 NASAP CASE 6.3.2, LMFBR U-Pu/Th, SPIKED RECYCLE, GENERAL ELECTRIC TRANSMUTER, HOMOGENEOUS CORE DESIGN . . . .

9.17.1 Fuel Cycle Description . . . . . . . . 230

9.17.2 Applicability to Current Fuel Element Design . . . 231 
9.17.3 Definition of Plant Production Requirements and Design Capacity ................

9.17.4 Estimates of Surge Storage Requirements, Scrap Production Rates, and Processing Rates for Functiona1 Steps . . . . . . . . . . .

9.17.5 Analysis of Functional Technology Status, Research and Development Requirements, Cost, and Schedule

9.17.6 Preliminary Cost Estimate for Construction and Operation of a Commercial-Scale Plant . . . . .

9.18 NASAP CASE 6.4, LMFBR Th-Pu/Th, SPIKED RECYCLE, GENERAL ELECTRIC TRANSMUTER [LMFBR $(\mathrm{Pu}, \mathrm{Th}) \mathrm{O}_{2} \mathrm{WITH} \mathrm{ThO}_{2}$ BLANKETS] • 242

9.18.1 Fuel Cycle Description . . . . . . . . 242

9.18.2 Applicability to Current Fuel Element Design . . 243

9.18.3 Definition of Plant Production Requirements and Design Capacity ............ 243

9.18.4 Estimates of Surge Storage Requirements, Scrap Production Rates, and Processing Rates for Functional Steps . . . . . . . . . . .

9.18.5 Analysis of Functiona1 Technology Status, Research and Development Requirements, Cost, and Schedule.

9.18.6 Preliminary Cost Estimate for Construction and Operation of a Commercial-Scale Plant . . . . 251

9.19 NASAP CASE 6.5, LMFBR DU(3)/Th RECYCLE . . . . . . 256

9.19.1 Fuel Cycle Description ........... 256

9.19.2 Applicability to Current Fuel Element Design . . 256

9.19.3 Definition of Plant Production Requirements and Design Capacity . . . . . . . . . 258

9.19.4 Estimates of Surge Storage Requirements, Scrap Production Rates, and Processing Rates for Functional Steps ................

9.19.5 Analysis of Functional Technology Status, Research and Development Requirements, Cost, and Schedule.

9.19.6 Preliminary Cost Estimate for Construction and Operation of a Commercial-Scale Plant . . . . . 
9. 20 REFERENCES . . . . . . . . . . . . . 268

10. SUMMARY AND CONCLUSIONS . . . . . . . . . . . 269

10.1 PROCESS DESCRIPTION . . . . . . . . . . 270

10.2 TECHNOLOGY STATUS . . . . . . . . . . . . 273

10.3 COST ESTIMATES FOR COMMERCIAL FACILITIES • • • • • • 275

10.4 CONCLUSIONS . . . . . . . . . . . . . 278

10.5 REFERENCE ..................... 278

APPENDIX: DESCRIPTION OF THE SPHERE CONVERSION PROCESS. • • . . 279

A. 1 FLOWSHEET AND PROCESS DESCRIPTION . . . . . . . . 279

A.1.1 Receiving and Storage ............ 281

A.1.2 Vacuum Evaporation and Acid Adjustment . . . . . 281

A.1.3 Mixing (Broth Preparation) .......... 281

A.1.4 Forming and Washing of Spheres.......... 281

A.1.5 Drying of Spheres . . . . . . . . . 281

A. 1.6 Sphere Inspection ............ 281

A.2 STATUS OF TECHNOLOGY AND RESEARCH AND DEVELOPMENT
REQUIREMENTS . . . . . . . . . . . . . . . 283

A.2.1 Scope .................. 283

A.2.2 Status............... 283

A. 2.3 Development Required .......... 283

A. 2.4 Research and Development Cost Estimate...... 284

A. 3 REFERENCES . . . . . . . . . . . . . . . 284 
We have evaluated the gel-sphere-pac fuel fabrication option and its possible application to commercial scale fuel fabrication for 19 fuel element designs that use oxide fuel in metal clad rods.

The ge1-sphere-pac process uses high-density spheres of the required fuel composition. The dry gel spheres are prepared at the reprocessing plant as an alternative product conversion step. In the fabrication plants described in this report these dry gel spheres are calcined, sintered, inspected, and are then loaded into fuel rods and packed by low-energy vibration. The resulting fuel bed, made of two or three sizes of spheres, will achieve a fuel smear density of 83 to $88 \%$ of theoretical.

We have defined and evaluated all fuel fabrication process steps from fuel receiving to finished fuel element shipping. Our evaluation also covers the feasibility of the process, the current status of technology, estimates of the required time and cost to develop the technology to commercial status, and the safety and licensability of commercial scale plants.

The primary evaluation was for a Light-Water Reactor fuel element containing (U, $\mathrm{Pu})_{2}$ fuel. The other 18 fuel element types -3 for LightWater Reactors, 1 for a Heavy-Water Reactor, 1 for a Gas-Cooled Fast Reactor, 7 for Liquid-Metal-Cooled Fast Breeder Reactors, and 3 pairs for Light-Water Prebreeder and Breeder Reactors - were evaluated by comparing them with the Light-Water Reactor.

The gel-sphere-pac option was found applicable to 17 of the 19 element types; the characteristics of a commercial scale plant were defined for these. These characteristics were then used as a basis for making cost estimates for such plants. These cost estimates include both capital costs and operating costs. When subjected to a financial analysis, these cost estimates provide estimated prices for the commercial fabrication of such fuel elements. These estimated prices are then suitable for comparison with similar estimates made previously for fabrication using the conventional pellet process. 
xiv

Our evaluation clearly shows the gel-sphere-pac process to be a viable fuel fabrication option. For the contact operated and contact maintained facilities and the remotely operated and contact maintained facilities, the estimates suggest only minor cost advantages for the gelsphere-pac process (in one instance a minor cost advantage is indicated for the pellet process). Based on our confidence in the estimates, we feel that no significant differences in costs exist for these cases. However, the estimates indicate a significant potential fabrication cost advantage for the gel-sphere-pac process if a remotely operated and remotely maintained fuel fabrication plant is required. 


\section{INTRODUCTION}

This report addresses the fuel fabrication option of using the ge1sphere-pac process for fabricating metal clad oxide fuels for a variety of reactor-fuel cycles. To provide a complete plant characterization in the generic description, it was necessary to select a specific cycle that would be representative and would allow the definition of mass flows throughout the plant. For the representative cycle we chose refabrication* of pressurized-water reactor (PWR) fuel elements with simultaneous production of fuel using three different enrichments, all with a spike to maximize proliferation resistance. This requires a plant that is remotely operated and maintained. Modifications to the plant to adapt it to other reactor type fuel elements and other fuels are addressed separately in Sect. 9.

The gel-sphere-pac process uses high-density spheres of the required fuel, which are loaded into the fuel cladding and packed by low-energy vibration to give a high smear density [about 83 to $88 \%$ T.D. (theoretical density)] fue1 rod. Dry gel spheres are prepared at the reprocessing plant during the product conversion step for the fissile material. This process - sphere conversion - is described briefly in the Appendix. Dry gel fissile spheres are received at the fuel fabrication plant where they are calcined, sintered to high density (greater than $98 \%$ T.D.), and loaded into fuel rods along with fertile fine spheres. The sintered fertile fine spheres are purchased from cold fabrication plants ready for use; this fabrication process is very similar to that described in the Appendix for larger spheres.

The sphere-pac process requires three size fractions to produce highdensity fuel rods. The fissile spheres are prepared in coarse (nominal 1200- $\mu$ m-diam) and medium (nominal 200- $\mu$ m-diam) sizes. The fertile fine spheres are prepared with a nominal diameter of $40 \mu \mathrm{m}$ and provide about $20 \%$ of the total heavy metal (HM).

*In this report, refabrication refers to the fabrication of bred fuel materials. 
This report also addresses the anticipated research, development, and demonstration ( $R D \& D)$ required to bring the sphere-pac process to a level suitable for commercial application. Since the basic process is essentially independent of the type of fuel being loaded, the RD\&D requirements are defined first for the generic process, and modifications only are provided in the specific cases. 


\section{DEFINITION OF THE GEL-SPHERE-PAC LWR PLUTONIUM RECYCLE FUEL FABRICATION PLANT}

\subsection{MAJOR ACTIVITIES}

The plant design concept in the generic portion of this report addresses only those processes directed toward the refabrication of fue 1 assemblies that contain $(\mathrm{U}, \mathrm{Pu})_{2}$ and that are designed for use in a light-water reactor. The processes are limited to the production of sintered $(\mathrm{U}, \mathrm{Pu})_{2}$ spheres, loading of fuel rods, assembly of these rods into a finished assembly, and the supporting activities necessary to perform these steps in a safe licensable commercial facility.

Since this refabrication plant is an integral part of the overall fuel cycle, it must interface with other activities within the cycle and is supported by external sources of supplies and materials. Figure 2.1 shows both the primary external process interfaces and some of the supporting activities within the plant.

The sphere-pac process depends on the reprocessing plant conversion product for its primary fuel component input (as does the pellet process). However, this feed material differs in form from the pellet process. The pellet process uses dry powders of $\mathrm{UO}_{2}$ and $\mathrm{PuO}_{2}$, which are subsequently blended and conditioned for process feed within the fabrication plant. The sphere-pac process feed is free-flowing, spherical, homogeneous $(\mathrm{U}, \mathrm{Pu})_{2}$ particles, which are formed in the product conversion process step of the reprocessing plant and which need only sintering to high density to be suitable for fuel rod loading. The $(\mathrm{U}, \mathrm{Pu}) \mathrm{O}_{2}$ spheres are obtained in two sizes, coarse (nominal $1200 \mu \mathrm{m}$ in diameter) and medium (nominal $200 \mu \mathrm{m}$ in diameter). In addition, natural (or depleted) $\mathrm{UO}_{2}$ in the form of very small (nominal 40- $\mu$-diam) dense spheres are used in the process. These "fertile fines" can be produced with an auxiliary process support activity in the refabrication plant or purchased from a supplier, as shown in Fig. 2.1. Hardware components, such as fuel rod cladding and material for the assembly skeletons, are also purchased from outside suppliers. 


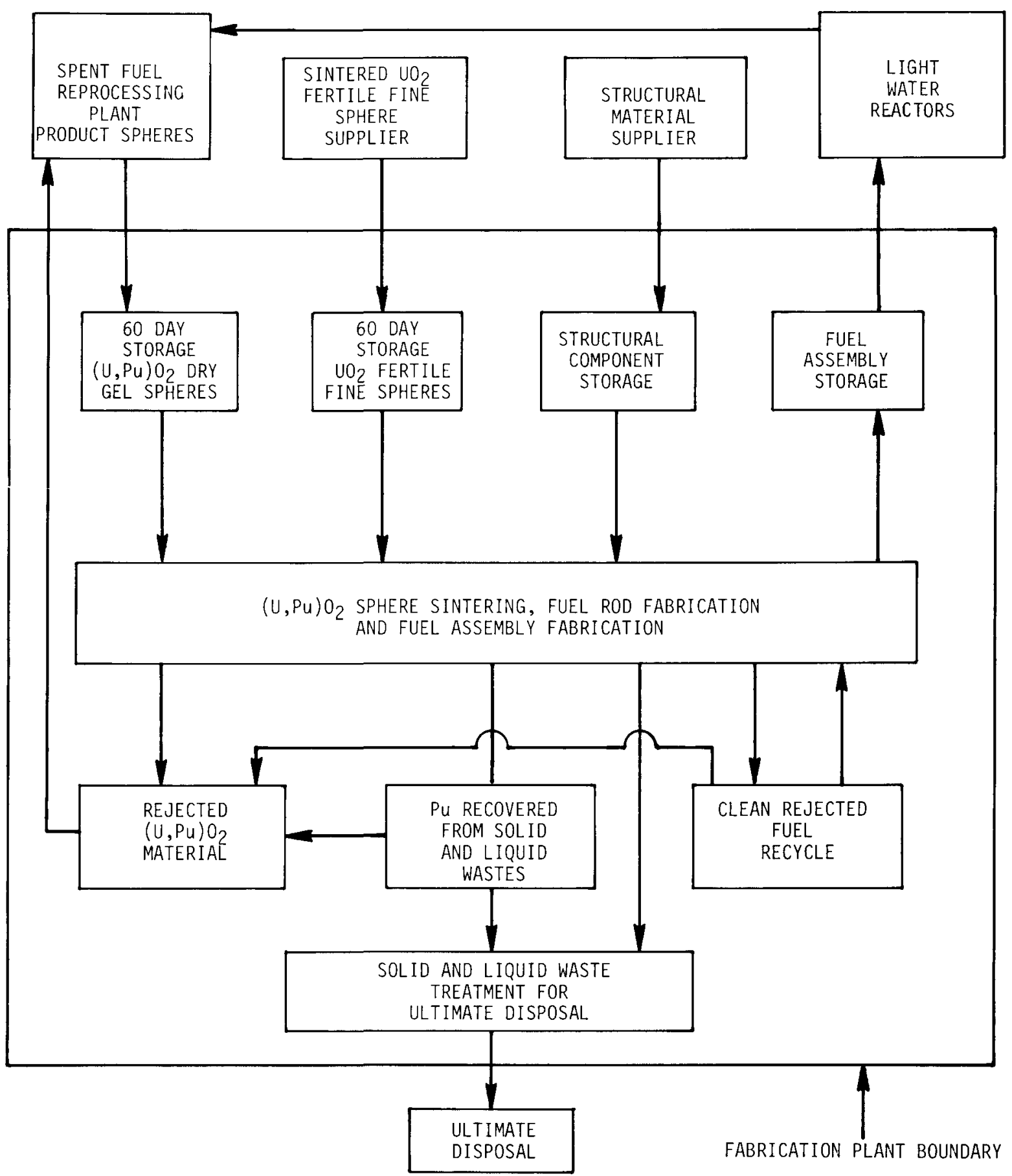

Fig. 2.1. LWR Recycle Plutonium Fuel Fabrication Plant. 
In the primary processing operation material is rejected by the quality control inspection functions. For the sphere-pac process rejected material is from two main sources: sphere inspection and fuel rod loading. The material rejected during fuel rod loading is internally recyclable with a minimum amount of rework (i.e., only size classification). The material rejected during sphere inspection is collected, weighed, assayed, and returned to the reprocessing plant for recycle. In addition to this clean scrap there are contaminated materials, both solid and liquid, which must be treated for ultimate disposal. Such treatment includes processing to recover plutonium (where possible), volume reduction, and conversion of the remaining waste to a form suitable for ultimate disposal.

\subsection{PLANT DESIGN CHARACTERISTICS}

To quantitatively evaluate the refabrication plant described in this report we must define certain design characteristics as follows:

1. The fuel element design is comparable to a current Combustion Engineering (CE) System 80 pressurized-water reactor element.

2. The plant production capacity is $480 \mathrm{t} \mathrm{HM} /$ year with the capability of simultaneously producing three enrichments.

3. The plant factor is 240 effective ful1-production days per year.

4. Plant design capacity:

Overal1

Each line of three
$730 \mathrm{t} \mathrm{HM} /$ year

about 5 fuel assemblies/d

$243 \mathrm{t} \mathrm{HM} /$ year

$0.67 \mathrm{tHM} / \mathrm{d}$

369 fuel rods/d

1.6 fue1 assemblies/d

5. Process design capacities are based on the line design capacities, equipment availability, and the scrap and sample losses.

6. The facilities are designed to discharge no liquid waste other than treated sanitary sewage.

7. All process buildings and critical auxiliary support are designed and constructed in accordance with the current U.S. Nuclear 
Regulatory Commission licensing requirements. Shielding is provided to limit dose rates to operating and maintenance personnel to $0.25 \mathrm{millirem} / \mathrm{h}$.

In addition to these basic assumptions we assumed that production from each fuel rod line is campaigned to provide a full reload segment for a single 1270-MWe (net) PWR before changing enrichments. Thus, the total HM output for a given campaign is $34.3 \mathrm{t}$, and each campaign requires about 51 effective full-production days ( 78 calendar days). The total facility can support about 14 reactors by using only $(\mathrm{U}, \mathrm{Pu}) \mathrm{O}_{2}$ fuel.

\subsection{OPERATING PHILOSOPHY}

For the remotely operated and remotely maintained facility (RO/RM) we assumed that the spike was introduced into the $(\mathrm{U}, \mathrm{Pu}) \mathrm{O}_{2}$ feed material at the reprocessing plant. We also assumed that the spike material and quantity would not affect subsequent process variables.

The plant is operated as a commercial facility with three shifts per day, seven days per week. Both operating and maintenance personnel are available on all four shifts, although there are some increases in the day-shift complement five days per week. Administrative and engineering personnel are involved only for day-shift operation five days per week.

All process operations in the facilities are to be mechanized for remote control by the operators. Internally recycled scrap materials are reworked within a designated process area for each fuel rod line to prevent possible mixing of enrichments. All fuel materials recovered in the waste treatment process are recovered as a mixed uranium-plutonium product and converted to a solid oxide before return to the reprocessing plant.

Personnel access to the feed materials storage area and the finished fuel element storage area is physically difficult, and material access ports are protected by multiple permission controls for safeguards considerations. On1y qualified plant personnnel may perform operations within the entire controlled area, including the operation of transportation equipment for shipping and receiving. 


\subsection{IN-PROCESS INVENTORY REQUIREMENTS}

We performed a total in-process inventory assessment of the refabrication plant on the assumption that all three fuel rod loading lines were in full production. This is presented in Table 2.1. 
Table 2.1. Surge Storage Requirements and Normal Inventory Based on CE System 80 Fuel Element Design

\begin{tabular}{|c|c|c|c|c|c|c|}
\hline & \multirow{2}{*}{ Process Step } & \multirow{2}{*}{ Material } & \multicolumn{2}{|c|}{$\begin{array}{c}\text { Storage } \\
\text { Interval, } \\
\text { d }\end{array}$} & \multicolumn{2}{|c|}{$\begin{array}{c}\text { Normal Inventory, } \\
\mathrm{kg} \mathrm{HM}\end{array}$} \\
\hline & & & Normal & $\operatorname{Max}$ & $(\mathrm{U}, \mathrm{Pu}) \mathrm{o}_{2}^{a}$ & $\mathrm{UO}_{2}$ Fines \\
\hline A. & Feed Storage & $\begin{array}{l}\text { Dried spheres } \\
\text { Sintered spheres }\end{array}$ & $\begin{array}{l}30 \\
30\end{array}$ & $\begin{array}{l}60 \\
60\end{array}$ & 50,000 & 13,000 \\
\hline B. & Interim Storage & $\begin{array}{l}\text { Dried spheres } \\
\text { Sintered spheres }\end{array}$ & $\begin{array}{l}1 \\
1\end{array}$ & $\begin{array}{l}2 \\
2\end{array}$ & 1,660 & 440 \\
\hline c. & Furnace & $\begin{array}{l}\text { Dried to sintered } \\
\text { spheres }\end{array}$ & 1.2 & 2.4 & 2,000 & \\
\hline D. & Post Furnace & Sintered spheres & 0.5 & 1 & 830 & \\
\hline E. & Interim Storage & Sintered spheres & 0.36 & 0.72 & 600 & \\
\hline F. & Main Storage & $\begin{array}{l}\text { Sintered spheres } \\
\text { Sintered spheres }\end{array}$ & $\begin{array}{l}1.2 \\
1.5\end{array}$ & $\begin{array}{l}2.4 \\
2.9\end{array}$ & 2,100 & 660 \\
\hline G. & $\begin{array}{l}\text { Loading, Inspection, } \\
\text { Welding }\end{array}$ & Sintered spheres & 0.12 & 0.24 & 210 & 50 \\
\hline $\mathrm{H}$. & $\begin{array}{l}\text { Loaded, not inspected } \\
\text { rods }\end{array}$ & & 5 & 5 & 8,300 & 2,070 \\
\hline I. & Rework - scrap & Sintered spheres & 0.12 & 0.24 & 410 & 75 \\
\hline $\mathrm{J}$. & Completed fuel rods & $\begin{array}{l}\text { Sintered spheres } \\
\text { in rods }\end{array}$ & 5 & 5 & 8,000 & 2,000 \\
\hline K. & Assemb1y & $\begin{array}{l}\text { Rods in completed } \\
\text { assemblies }\end{array}$ & 15 & 30 & 24,000 & 6,000 \\
\hline
\end{tabular}

\footnotetext{
$a_{5.6 \% \text { nominal fissile plutonium content. }}$
} 


\section{FABRICATION PROCESSES}

This section will describe each main fuel fabrication step. Process flowsheets are included in the discussion, with a description of product control and scrap and waste processing and disposal.

\subsection{PRODUCT MANUFACTURE}

\subsubsection{Flowsheet and Process Descriptions}

A gel-sphere-pac generic functional flow diagram is shown in Fig. 3.1 . The main functions unique to the ge1-sphere-pac process are fuel production (2.0) and fuel rod fabrication (3.0). Brief process descriptions of the various functional steps are given below.

\subsubsection{Receiving and Storage}

As shown in Fig. 3.2 the containers of dried gel spheres (two sizes of each of three assay levels) of $(\mathrm{U}, \mathrm{Pu}) \mathrm{O}_{x}$ are received from the reprocessing plant, weighed, and stored. These container weights and their respective accompanying samples are the bases of inventory control of material entering the plant. Similarly, the sintered spheres of natural (or depleted) $\mathrm{UO}_{2}$ fertile fines are received, weighed, and stored. As required by the process a container is sampled and held in interim storage (pneumatic transfer hopper) until it is verified to be acceptable. It is then pneumatically transferred to fuel rod fabrication.

\subsubsection{Fue1 Production}

The purpose of the fuel production step is to convert the dry gel spheres to the high-density sintered spheres required for sphere-pac loading. This is accomplished by calcination and sintering, as shown in Fig. 3.3.

As material is required for fuel production individual containers are removed from storage and passed successively through a sampler and a 
ORNL DWG 78-13963

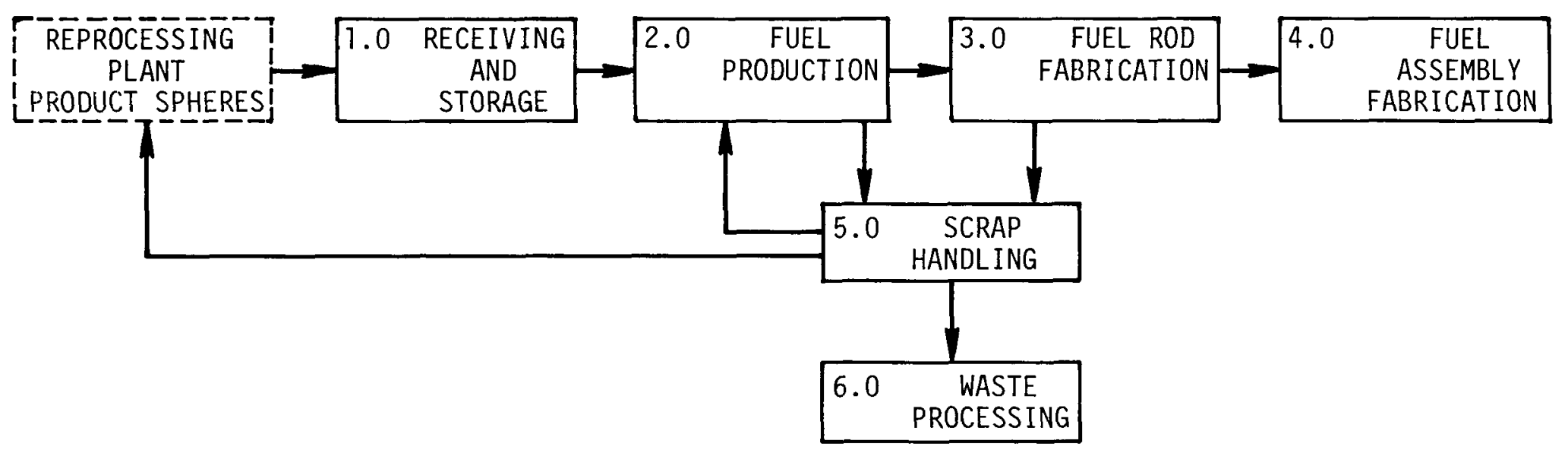

Fig. 3.1. Gel-Sphere-Pac Generic Fuel Refabrication Functional Flowsheet. 
ORNL DWG 78-13964

U-PU FISSILE LINE

$\mathrm{UO}_{2}$ "COLD" LINE

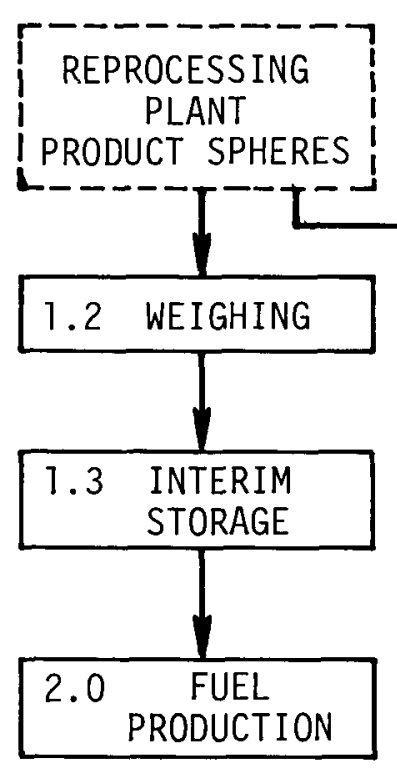

SINTERED FERTILE FINE SPHERE SUPPLY

PRODUCT SPHERES
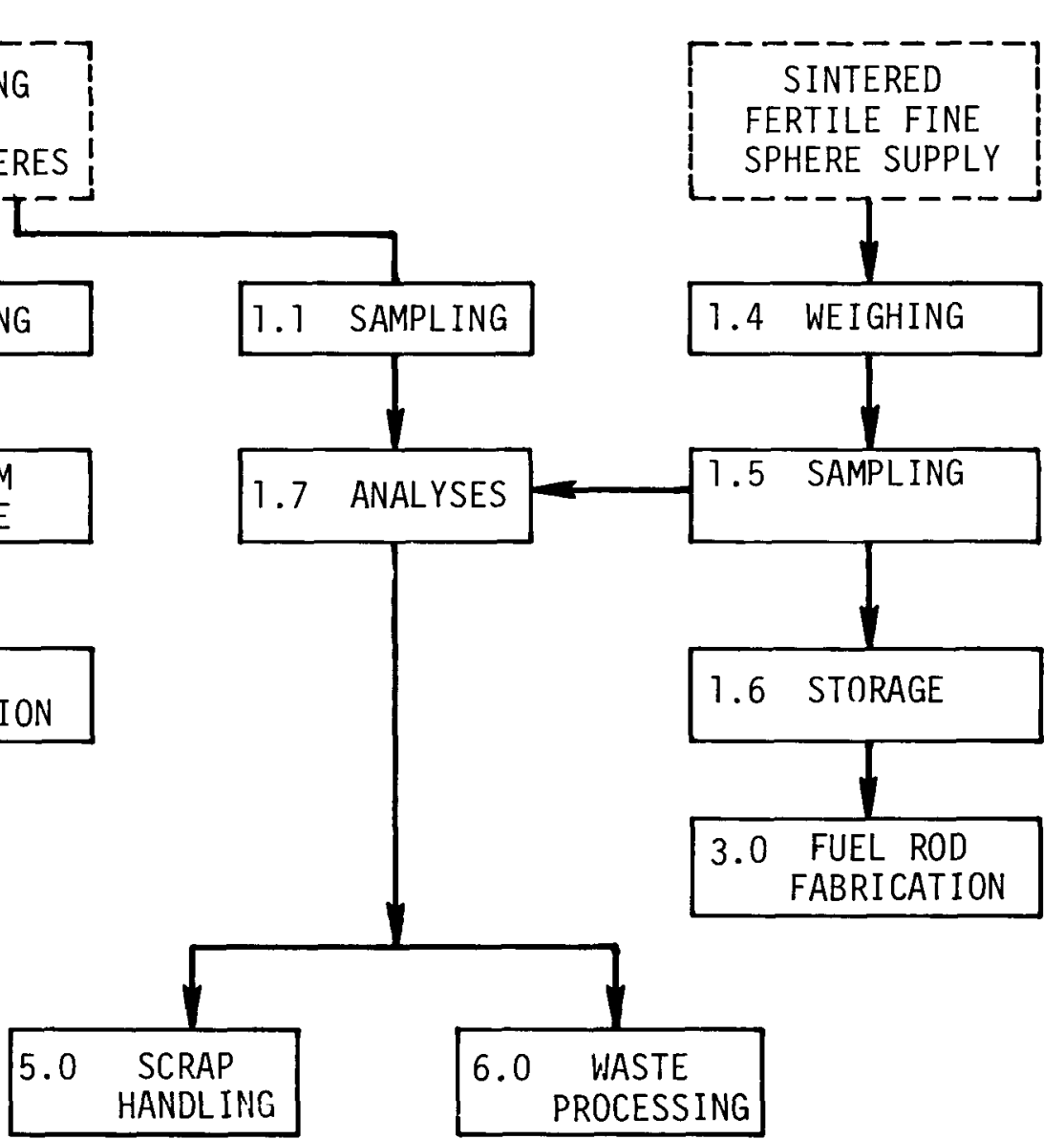

Fig. 3.2. Ge1-Sphere-Pac Generic Functional Flowsheet -1.0 , Receiving and Storage. 


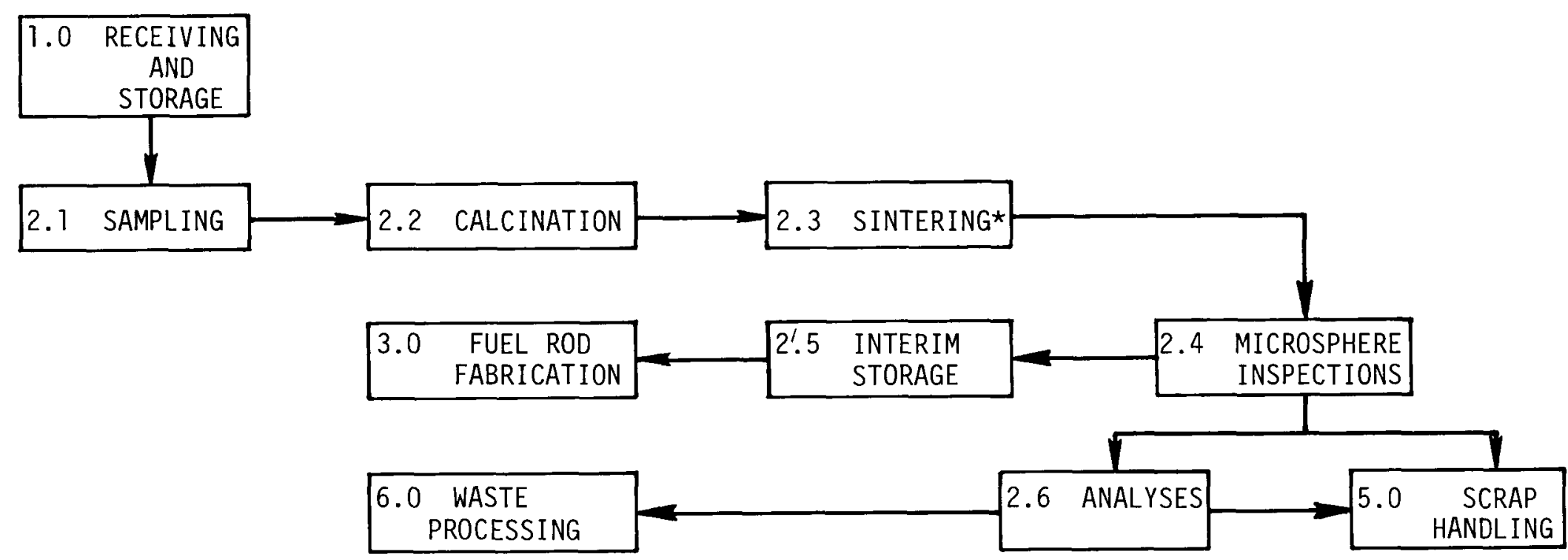

*INCLUDES O/M ADJUSTMENT

Fig. 3.3. Gel-Sphere-Pac Generic Functional Flowsheet - 2.0, Fuel Production - U, Pu Fissile Stream. 
splitter. The splitter subdivides the batch and loads it into the furnace boats. After the material is verified to be acceptable, the boats are loaded into one of the calcination-sintering furnaces. There are three main production lines (one for each assay level), each containing three furnaces.

The calcination portion of the cycle heats the particles to about $500^{\circ} \mathrm{C}$ in a reducing atmosphere to remove the volatiles and to reduce the uranium to $\mathrm{UO}_{2}$. Following calcination the particles are reduced and sintered to high density by continuing to heat them in a reducing atmosphere to a maximum temperature in the range of 1450 to $1650^{\circ} \mathrm{C}$. The as-sintered particles [now $(\mathrm{U}, \mathrm{Pu}) \mathrm{O}_{2}$ with the oxygen-to-metal ratio adjusted] are cooled, unloaded, and transferred to sphere inspection. In this step the particles are size and shape classified, sampled, and held in interim storage (pneumatic transfer hoppers) until quality control analyses are complete. Upon verification of the acceptability of the material the particles are pneumatically transferred to fuel rod fabrication. Reject material from size and shape classification and material that does not meet specifications are sent to scrap handling. Waste from laboratory analysis is routed to waste processing.

\subsubsection{Fuel Rod Fabrication}

The main purpose of the fuel rod fabrication step is to load the high-density spheres into high-density rods by using low-energy vibration. The various steps of fuel rod fabrication are shown in Fig. 3.4. The main storage hoppers receive and store acceptable sintered spheres until needed for rod loading. There are three fuel rod loading lines, one for each of the assay levels. Each fuel rod loading line has three storage hoppers for the coarse spheres, medium spheres, and fines, respectively. Each hopper provides storage for two days of operation.

The amount of each type of sphere needed for a fuel rod is volumetrically dispensed from each of the three hoppers, weighed, and transferred to the corresponding three hoppers of the loading line. The material from all three loading hoppers is simultaneously dispensed, blended, and loaded into the cladding tube. Each loading line has a 


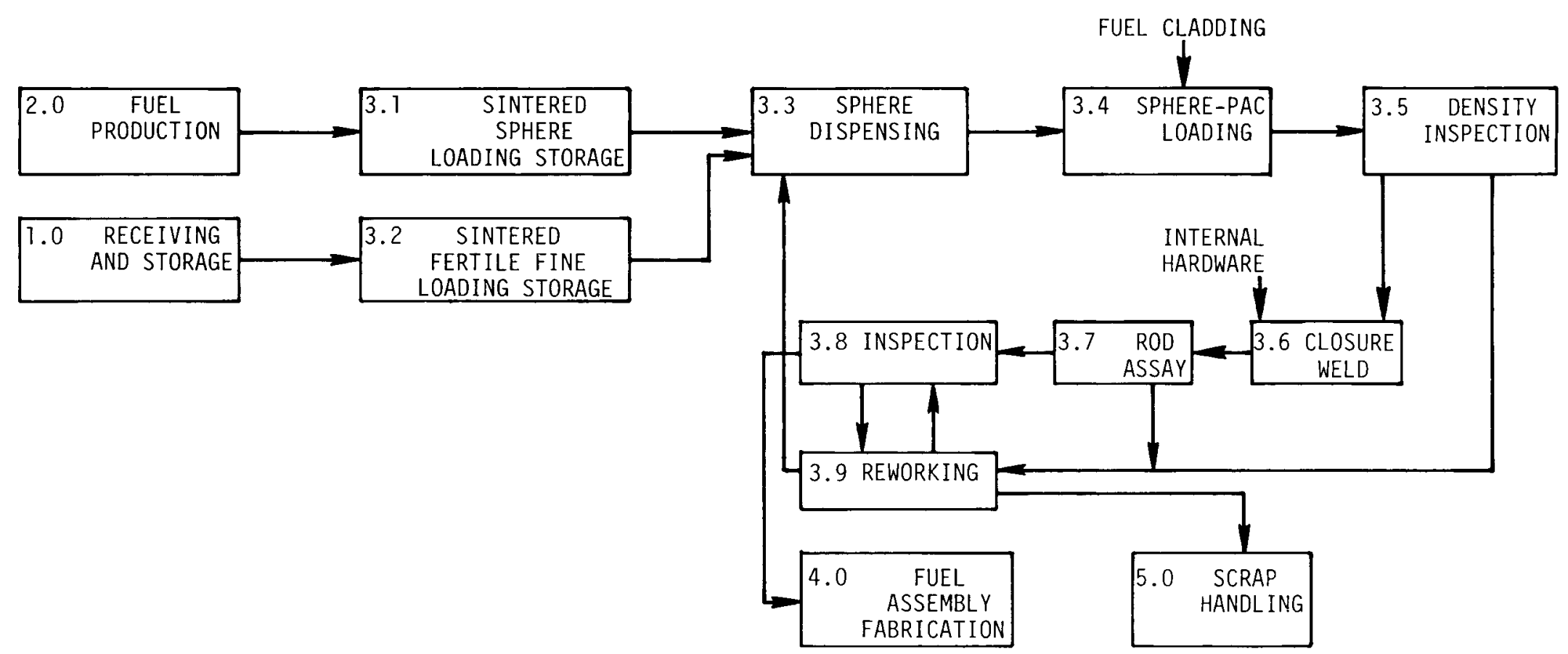

Fig. 3.4. Gel-Sphere-Pac Generic Functional Flowsheet - 3.0, Fuel Rod Fabrication. 
single blender-feeder, which alternately feeds each of three loading stations of the line by use of a rotary diverter valve. After being filled the fuel rods are vibrated to achieve the proper fuel column length and density.

The loaded rods are moved to one of the two densitometer stations where both the fuel column length and the fuel density along the length are determined. Rods that do not meet specifications are transferred to the density reject station before being sent to the rework area.

Fuel rods that meet specifications are advanced to the subsequent stations where the weld area is cleaned; the remaining top components (disk, spring, etc.) are added; and the rod is evacuated, pressurized, and welded.

The rods are rotated to a horizontal position and loaded on racks for closure weld x-ray examination. After passing the subsequent helium leak check, all rods are decontaminated and passed from the fuel rod fabrication area to the final rod inspection and fuel assembly area of the plant. Surge storage is provided at this point to permit campaigning of common assay rods through the nondestructive assay and fuel rod dimensional inspection stages. Rods that meet specifications are sent to fuel assembly fabrication, while rods that do not meet specifications are transferred to the rework area. From the rework area rods are either returned for reinspection or unloaded and the particles returned to the dispensing and loading area (following size classification). The hardware is recycled or sent to scrap handling, depending on its condition.

\subsubsection{Fuel Assembly Fabrication}

Acceptable fuel rods are stored in vaults within the fuel assembly area. A single fuel assembly line meets the production requirements and handles the output from all three fuel fabrication lines, as shown in Fig. 3.5. Identified rods of a given assay are withdrawn from storage and loaded into a magazine. The magazine is then mated with a prefabricated fuel assembly skeleton and the rods drawn into the assembly. Each assembly is then upended and subjected to a series of inspection and 
ORNL-DWG 78-13967A

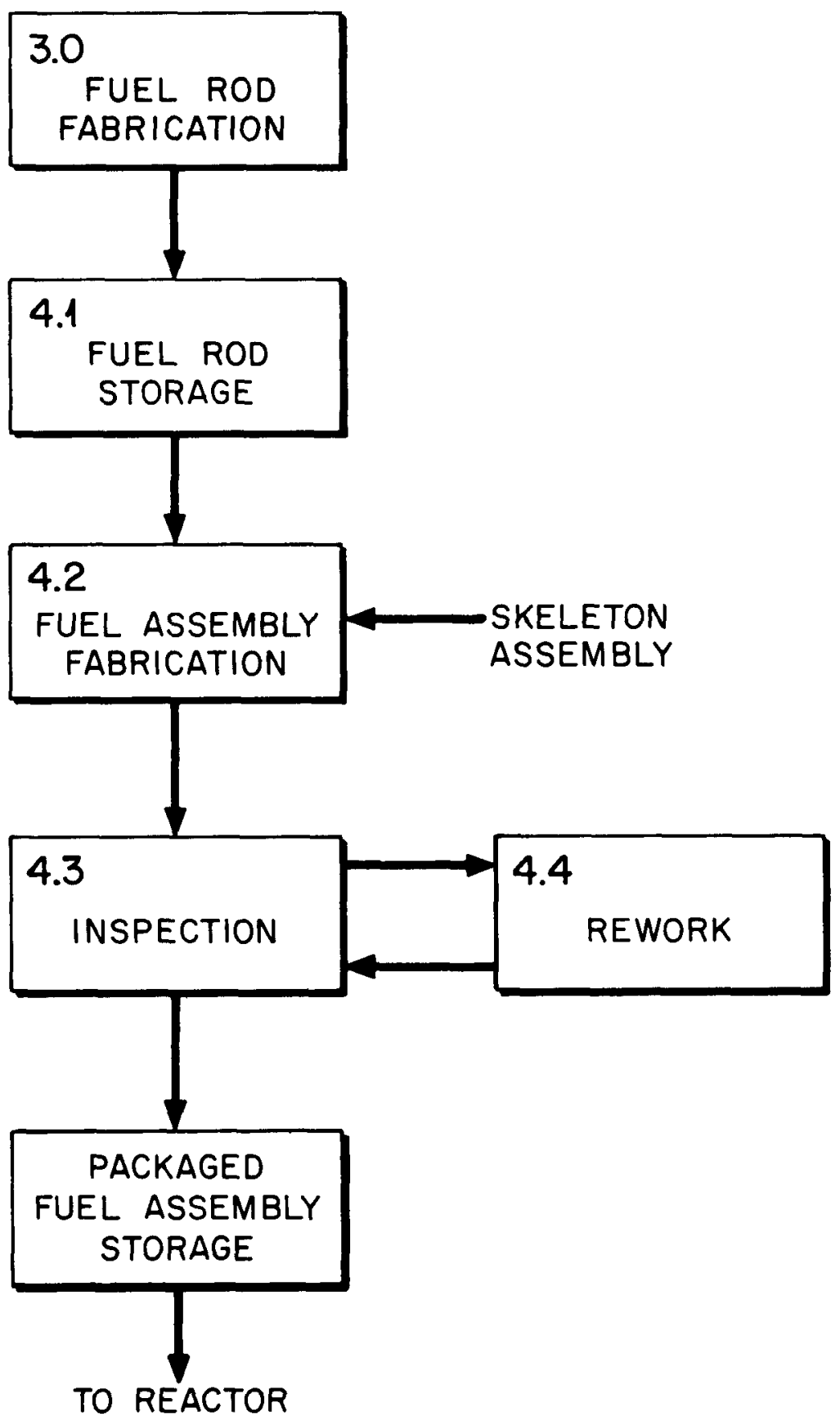

Fig. 3.5. Ge1-Sphere-Pac Generic Functional Flowsheet - 4,0, Fue1 Assembly Fabrication. 
cleaning operations before being placed in a protective package. Packaged assemblies are stored in a vault and then shipped to various reactors as required.

\subsubsection{Product Control Processes}

To ensure the production of a high-quality product, sampling and testing are performed throughout the various process steps. This includes analyzing the as-received dried spheres (coarse and medium) for accountability (heavy metal content) and quality control (impurities). After sintering particles of all three sizes receive more complete analysis since the process is complete and the particles are ready for loading. Analyses of sintered particles include total fissile content, uranium-toplutonium ratio, oxygen-to-metal ratio, impurities, gas content, moisture content, particle size distribution, and nitrogen content. After the fuel rod is loaded the total heavy metal and fissile element content and distribution along the fuel column length are determined. The various samples and tests are divided into three types of controls:

1. "In-line" controls are nondestructive controls on $100 \%$ of the product. Essentially all of the testing is of this type once the sintered particles are loaded into the fuel cladding. The contents of out-of-specification rods are recycled to the system just ahead of the rod loading step.

2. "On-1ine" controls are statistical examinations, such as extracting part of the particles for particle size distribution. In addition on-line controls include processing equipment atmosphere analyses and maintenance.

3. "Off-line" controls are statistical nondestructive and destructive controls on part of the product. The bulk of such controls are tests on control and analytical samples that have been transported (normally by pneumatic means) to the laboratory. Examples include analyses of impurities and heavy metal content (of particle samples and reject material), moisture content, particle density, plutonium-to-uranium ratio, and oxygen-to-metal ratio, and isotopic assay. 
3.2 SCRAP AND WASTE PROCESSING AND DISPOSAL

\subsubsection{Scrap Handling}

As shown in Fig. 2.1 three types of scrap material are generated in a sphere-pac mixed oxide fuel fabrication plant. These are: clean (internally recycled), rejected (externally recycled), and recoverable plutonium from solid and liquid wastes. Clean scrap occurs when a fuel rod is rejected for failure to meet mechanical (e.g., poor weld), density, or homogeneity specifications. When this occurs the spheres are poured out, sized, and returned to the appropriate storage container. Any degraded spheres are transferred to the second category of scrap material (rejected).

Re jected material consists of sintered spheres that fail to meet the sphere specifications. Rejected material is collected, assayed, and shipped back to the reprocessing plant for dissolution and conversion to gel spheres (see Fig. 3.6 for a flowsheet description).

The third type of scrap, recoverable plutonium from solid and liquid wastes, is separated from the solid and liquid wastes, converted to a solid oxide, and transferred to the rejected $(\mathrm{U}, \mathrm{Pu}) \mathrm{O}_{2}$ material.

Table 3.1 provides a quantitative evaluation of expected mass flow, yield, and scrap generation for the sphere-pac refabrication plants. As indicated the quantity of clean (internally recycled) scrap anticipated is about $8 \%$. The amount of rejected (externally recycled to the reprocessing plant) scrap is about $4 \%$. The overall product yield is about $99 \%$.

\subsubsection{Waste Processing and Disposa1}

Waste handling and disposal are shown in Fig. 3.7. As described in Sect. 3.2.1 recoverable uranium-plutonium is separated from waste as part of scrap recovery. However, some mixed oxide is not recoverable and is lost as waste to permanent disposal. This quantity is expected to be less than $0.25 \%$ of the total amount of plutonium treated. 
ORNL DWG 78-13968

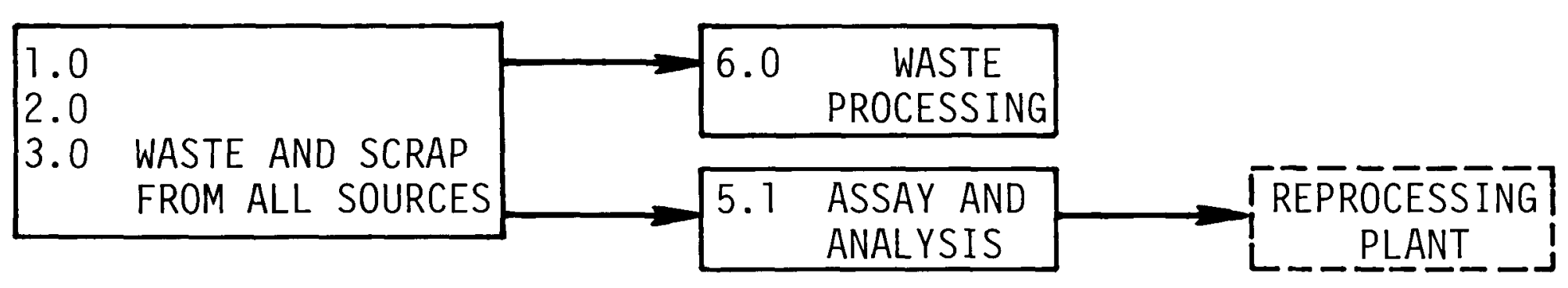

Fig. 3.6. Ge1-Sphere-Pac Generic Functional Flowsheet - 5.0, Scrap Handling. 
Table 3.1. Estimated Daily Scrap Production for a 480-t HM/year LWR Plutonium Recycle Fuel Plant

\begin{tabular}{|c|c|c|c|c|c|c|}
\hline \multirow{3}{*}{ Processing Step } & \multicolumn{6}{|c|}{ Mass Flow, $\mathrm{kg} \mathrm{HM} / \mathrm{d}$} \\
\hline & \multicolumn{2}{|c|}{ Daily Throughput } & \multicolumn{2}{|c|}{ Clean Scrap ${ }^{a}$} & \multicolumn{2}{|c|}{ Reject Scrap $b$} \\
\hline & $(\mathrm{U}, \mathrm{Pu}) \mathrm{O}_{2}{ }^{\mathrm{c}}$ & $\mathrm{UO}_{2}$ Fines & $(\mathrm{U}, \mathrm{Pu}) \mathrm{O}_{2}{ }^{\mathrm{C}}$ & $\mathrm{UO}_{2}$ Fines & $(\mathrm{U}, \mathrm{Pu}) \mathrm{O}_{2}{ }^{\mathrm{e}}$ & $\mathrm{UO}_{2}$ Fines \\
\hline Receiving and Storage & 1662.3 & $437.8^{d}$ & & & & \\
\hline Sampling and Batch Loading & 1660.6 & & & & 1.7 & \\
\hline Weighing and Sampling & & 437.4 & & & & 0.4 \\
\hline Calcining and Sintering & 1659.8 & & & & 0.8 & \\
\hline Sphere Upgrading & $1753.1^{e}$ & & & & 49.8 & \\
\hline Sphere Sampling & 1749.6 & & & & 3.5 & \\
\hline Sphere Storage & 1749.6 & 437.4 & & & & \\
\hline Fue1 Rod Loading & 1749.6 & 437.4 & & & & \\
\hline Fuel Rod Scanning & 1662.1 & 415.5 & 84.0 & 21.0 & 3.5 & 0.9 \\
\hline Top Component Insertion & 1658.4 & 414.6 & 3.3 & 0.8 & 0.3 & 0.1 \\
\hline Rod Welding and $X$ Ray & 1658.4 & 414.6 & $f$ & $f$ & $f$ & $f$ \\
\hline Leak Detection & 1658.4 & 414.6 & $f$ & $f$ & $f$ & $f$ \\
\hline Rod Assay & 1625.3 & 406.3 & 31.5 & 7.9 & 1.7 & 0.4 \\
\hline Final Rod Inspection & 1608.4 & 402.1 & 16.3 & 4.1 & 0.7 & 0.2 \\
\hline Assembly Inspection & 1600 & 400 & 8.0 & 2.0 & 0.3 & 0.1 \\
\hline Total & 200 & & 143.1 & 35.8 & 62.3 & 2.1 \\
\hline
\end{tabular}

Internally recycled.

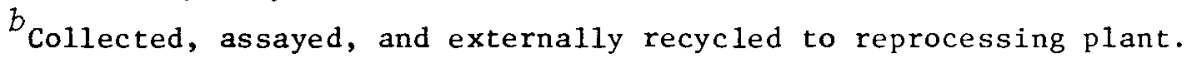

$c_{3.1 \% \text { nominal fissile plutonium. }}$

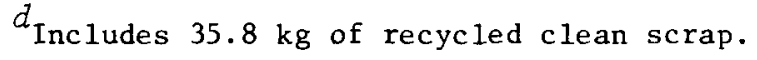

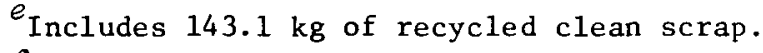

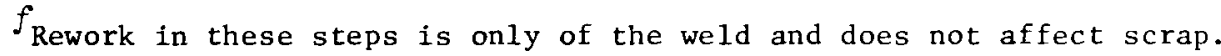


ORNL DWG 78-13969

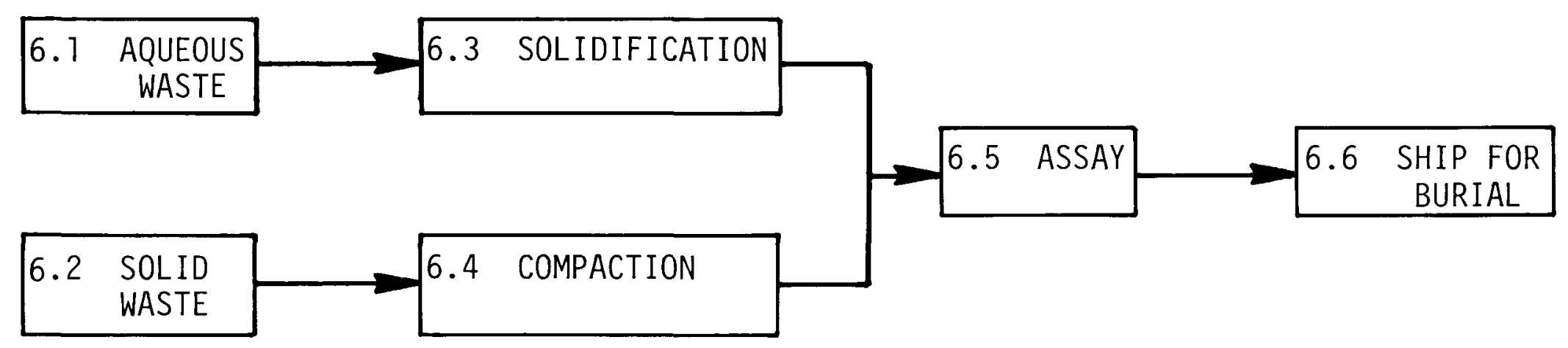

Fig. 3.7. Gel-Sphere-Pac Generic Functional Flowsheet - 6.0, Waste Processing. 
Following the plutonium recovery step aqueous wastes are concentrated and solidified while solid wastes are compacted; both are assayed and shipped for permanent disposal. 


\section{PLANT GENERAL LAYOUT AND DESCRIPTION}

4. 1 GENERAL LAYOUT

A typical site plan for a refabrication plant producing $480 \mathrm{t} \mathrm{HM} /$ year as PWR fuel elements is given in Fig. 4.1. This plan was developed to show the principal components and is not an actual concept. To provide for physical safeguards there are appropriate boundary areas with increasing control of access. The entire site is surrounded by a fence with monitoring and access control. Within this perimeter is a controlled area with appropriate fencing and intrusion monitoring. A third level of access control is then applied to process buildings, which are further subdivided for limitation of personnel access.

Only appropriately cleared personnel are allowed in the various areas; this includes operators of heavy trucks and trains within the site perimeter on the road and rail accesses shown in the site plan.

\subsubsection{Site Perimeter}

Site access through the perimeter fence is controlled through the main entrance and guard shacks at the vehicular entrances. The administration and engineering building though within the perimeter area is outside the controlled area to permit interchanges with customers and vendors and to reduce the number of personnel within the controlled area.

\subsubsection{Controlled Area}

A11 personnel access to the controlled area is through the portal entrance controlled by guards. Within the controlled area are located the manufacturing process building and critical auxiliary functions as well as an appropriately protected guard center and communications center that remotely monitors all physical protection activities. The auxiliary function areas accessible from the controlled area portal are: 


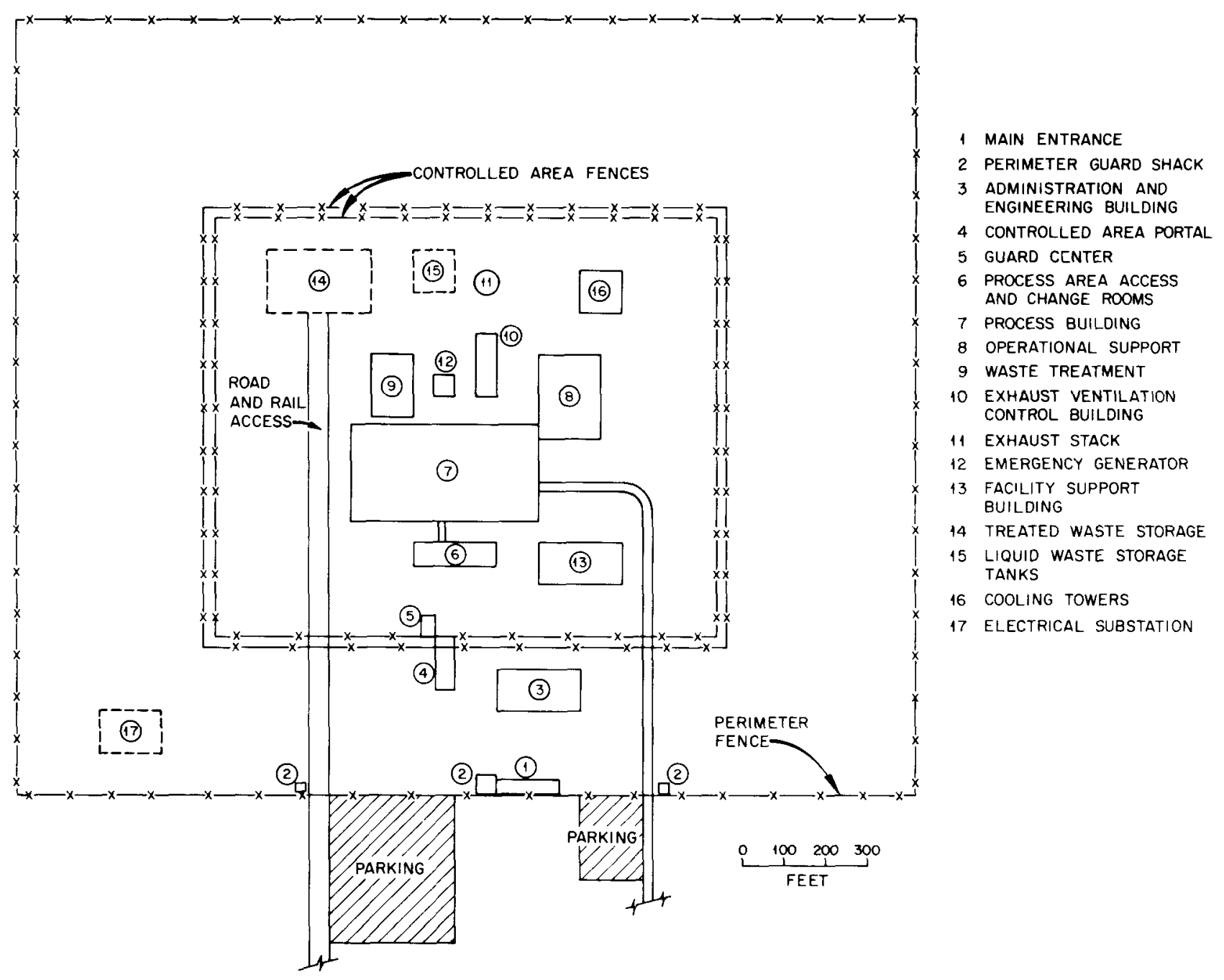

Fig. 4.1. Site P1an for 480-t HM/year Sphere-Pac LWR Fabrication Plant. 
1. the facility support building, which includes appropriate process material warehousing and general shops;

2. the exhuast ventilation control building and its associated stack;

3. the emergency electrical power generation building;

4. the cooling towers;

5. various yard facilities, including waste storage areas; and

6. limited portions of the receiving and shipping areas associated with the process areas.

\subsubsection{Process Areas}

Access to the actual processing buildings is through a separate building, which includes facilities for locker rooms and some operational management offices. All personnel entering or leaving the three interconnected process buildings must pass through appropriate guards and monitoring devices. The three process buildings provide space for:

1. the actual fuel element production,

2. the fuel element hardware manufacture and inspection together with other process support activities, and

3. the treatment of all process waste.

\subsection{GENERAL DESCRIPTION}

The fuel element manufacturing processes were described in Sect. 3. In this section attention is focused on a description of the main process buildings.

\subsubsection{Operational Support Building}

Most of the structural materials components in a finished fuel assembly, with the exception of the cladding, are manufactured within the plant. Consequently, the operational support building houses such activities as fue1 cladding storage, inspection, cleaning, bottom end-plug insertion and welding, and loading of appropriate magazines to deliver these to the 
fuel fabrication area. Element components are manufactured and assembled into finished and inspected element skeletons in a separate area. Additional equipment and space is provided to test and modify, as necessary, al1 new fixtures and replacement equipment to ensure their functional performance and interface compatibility with manufacturing process area supports, utility connections, and adjacent equipment.

\subsubsection{Process Building}

The process building houses all the actual fuel element manufacturing processes and the appropriate quality control and maintenance activities. Although actually subdivided into several smaller areas, these can be grouped by activities. The processing areas are physically separated by appropriate shielding walls but are remotely interconnected to provide for material movement. A preliminary layout for the processing areas is given in Fig. 4.2. Only the principal processing areas are shown. Remote maintenance cells are located above the processing cells together with the quality control laboratories. Additional building space houses auxiliary services and instrumentation.

\subsubsection{Mixed Oxide Receiving and Supp1y Storage}

The $(\mathrm{U}, \mathrm{Pu})_{2}$ gel spheres are received and stored in one area. Each shipment may contain several sealed containers. The identification and weight of each container are checked. The containers are individually transferred through a lock to the vault storage area and are placed in predetermined and monitored storage wells by remotely operated equipment. Separate locks are provided for the transfer of containers to the fuel processing and rod fabrication areas and for the removal of empty containers to the reprocessing plant for reuse. All activities in the vault area require multiple approval and are monitored by accountability and safeguards personnel. 


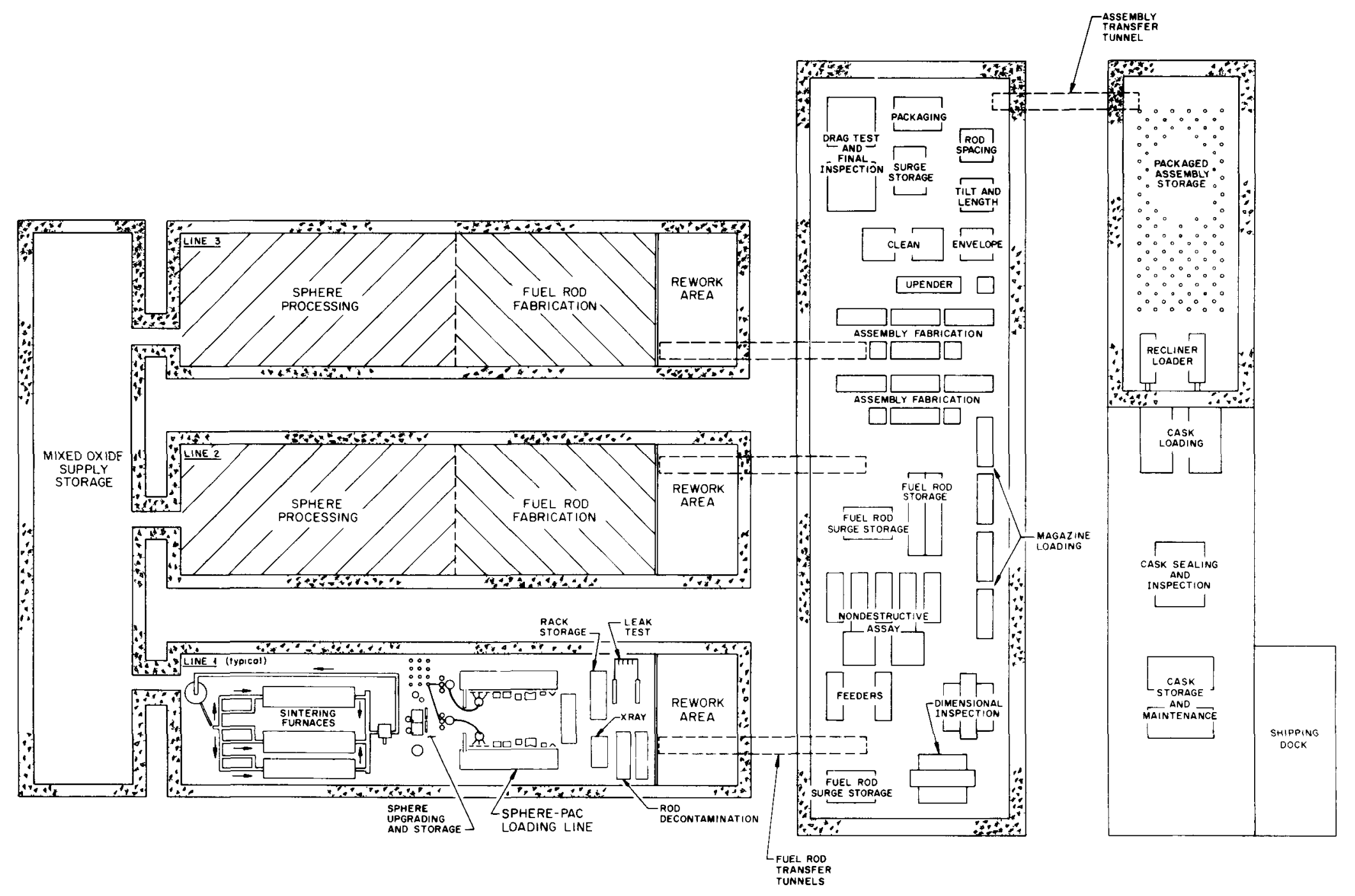

Fig. 4.2. Preliminary Layout of Processing Areas for Ge1-Sphere-Pac Fabrication of Spiked $(\mathrm{U}, \mathrm{Pu})_{2}$ LWR Fuel Assemblies. 


\subsubsection{Sphere Processing Area}

The second general area includes all equipmment to sample batches of dried spheres from the storage area, to sinter the spheres to high density, and to subsequently upgrade and sample the sintered product. Qualified product is accumulated in storage as feed to the fuel rod fabrication process. From the time the sintering boats enter the sintering furnace, all processing and transfers are conducted within confinement. Sintered spheres are transferred pneumatically between processing stations.

\subsubsection{Fuel Rod Fabrication}

The third area includes all equipment necessary to dispense spheres, load the fuel rods, and perform inspections to assure fuel rod integrity. The interface between sphere processing and fuel rod fabrication is the storage area. Three sizes of spheres are transferred from storage to the volumetric dispensing station. Material suitable for one fuel rod is transferred to the sphere-pac loading line, as shown in Fig. 4.3. Two such lines are proposed for each of the three assay areas to provide redundant capacity. Current estimates indicate that each sphere-pac line

will fabricate fuel rods at the required rate.

Fuel rods are fabricated vertically but are laid down at the $x$-ray rack loading station. Subsequent handling is horizontal with support along the length of the rod to prevent mechanical deformation. Following closure weld $x$-ray inspection and helium leak testing provisions have been made to decontaminate any rods with external surface contamination before transferring them to the final inspection and element assembly area.

\subsubsection{Rework areas}

An area for rework and internal recycle of fuel and fuel rods is provided for each fuel rod fabrication line to prevent mixing of different assay materials. This area is isolated from the fuel rod fabrication area by a thin removable barrier. Functions include removal of end plugs from 
ORNL-DWG 78-17121R

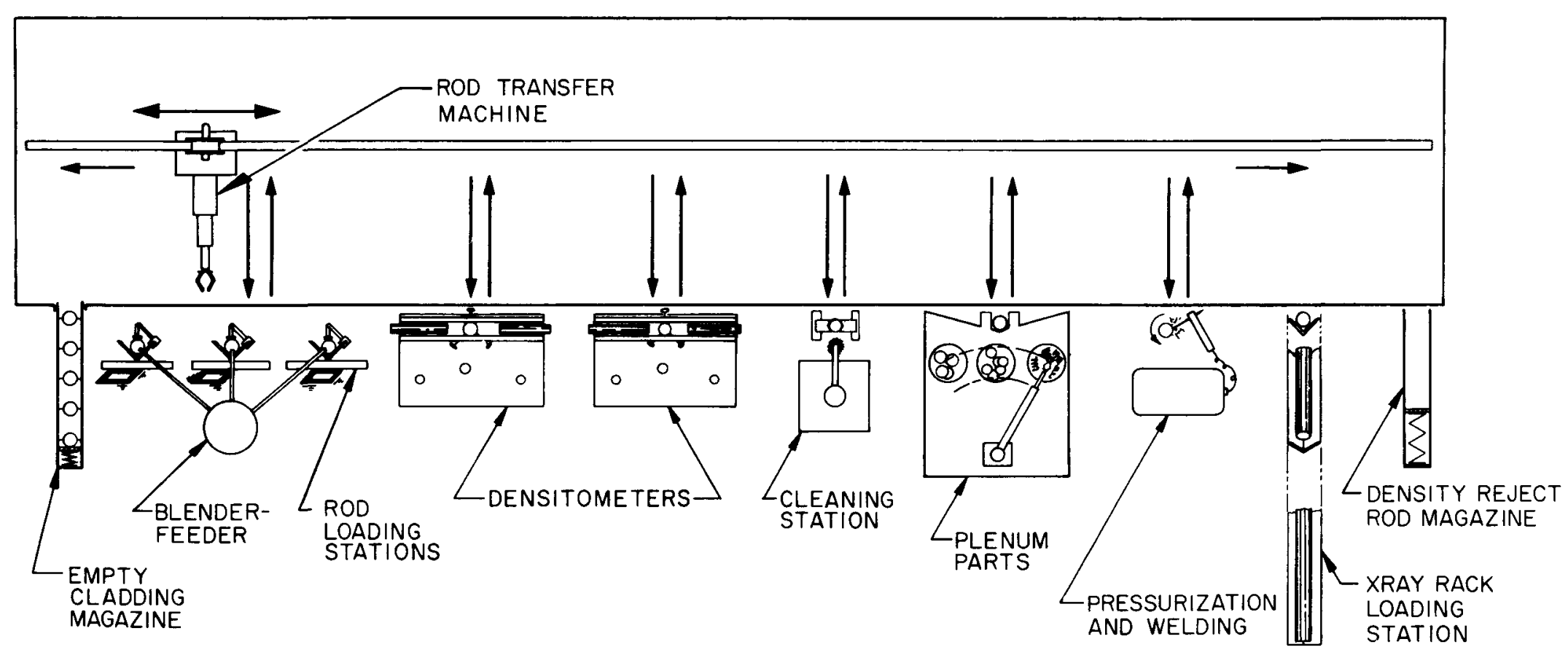

Fig. 4.3. Conceptual Sphere-Pac Loading Line. 
defective welds, total disassembly of fuel rods, recovery of fuel with subsequent screening and sorting for recycle, and accumulation of reject materials to be returned to the reprocessing plant for total recycle.

4.2.2.5 Final Fuel Rod Inspection and Element Assembly

Since only five fuel elements per day are produced at full capacity, a single manufacturing line can accommodate the output from all three fuel rod fabrication lines. Again, this area is physically separated from the fuel rod fabrication areas but remotely interconnected. This separation provides additional protection against accidental contamination of the exterior surfaces of the finished assembly. The area includes surge storage for the fuel rods as received and after final inspection as well as equipment for the final inspection and nondestructive assay. Equipment that loads the fuel rods into the assembly skeleton, inspects the assembly, and places it in a shipment support package completes the contents of this area.

\subsubsection{Assembly Storage and Shipping}

The final area in the direct manufacturing process line is the storage vault and shipping location for completed assemblies. This vault is similar to but smaller than the fuel receiving storage vault. Space and equipment for loading the shipping containers and placing these on the appropriate off-site carrier is provided near the vault.

\subsubsection{Fabrication Process Support Areas}

Although not shown on the preliminary layout drawing (Fig. 4.2), the fabrication process building includes several other functional areas. Around, above, below, and adjacent to the direct manufacturing process areas are sites for process control. These include such off-line activities as process control operating areas and analytical laboratories for sample analyses for process control, product quality assurance, and 
confirmation of plant effluent control monitoring. Significant space is required for process equipment maintenance, and these areas provide shielding, decontamination, and confinement of contamination. Space is also provided for process services including utilities, for material movements with limited local storage, and for special ventilation equipment and controls. Also located within this main process building is an area for safeguards and accountability monitoring and control with the appropriate computer capabilities and limited office space for process management personnel.

\subsubsection{Waste Treatment Building}

The waste treatment building contains both shielded and unshielded areas as required to protect operating personnel. The primary waste treatment processes in a fuel manufacturing plant involve treatment of solid wastes, both combustible and noncombustible, to reduce the volume and packaging the remaining materials into containers for off-site shipment and disposal. However, all liquid waste from activities within the controlled area are collected and monitored for plutonium and uranium content. Only the liquid from treated sewage is discharged from the plant. Other low contamination level liquids are treated for recovery and recycle. Excess water is discharged as a vapor in the ventilation exhaust. Liquids with significant quantities of heavy metal are chemically processed to recover the uranium and plutonium and to concentrate other contained solids and salts. These liquids include the analytical laboratory wastes, decontamination solutions, and solutions from leaching of highly contaminated wastes, such as the filters as well as the concentrated low-level wastes. The resulting alpha-contaminated concentrates are immobilized in concrete or glass. All solid waste is placed in appropriate shipping and disposal containers, assayed, and sent to treated waste storage before off-site shipment. All process equipment in the waste treatment area is contained within controlled areas to confine and test ali gaseous effluents before release to the plant exhaust system and the stack. 
0 


\section{PLUTONIUM CONF INEMENT AND VENTILATION SYSTEMS}

\subsection{CONFINEMENT SYSTEMS}

Various plant enclosures and their heating, ventilating, and airconditioning (HVAC) systems serve to minimize and restrict the release of plutonium-bearing materials to as low a level as practicable. Such enclosures include fuel fabrication areas; hot repair cells; decontamination areas; sphere transferring equipment; storage areas; shipping containers; and the walls, floors, and ceilings of buildings and rooms. The combination of all the various enclosures and interconnected HVAC systems of a building or of one or more rooms in a building constitutes the "confinement system" for that building, room, or set of rooms.

The three physical zones in the fuel fabrication building are:

1. restricted access - houses equipment containing special nuclear materials (SNM),

2. limited access - provides sampling and maintenance access to the restricted access zone, and

3. normal access - houses operational controls and controls normal personnel flow.

The barriers of an enclosed zone are designated by classification; that is, restricted access zones are defined by restricted access barriers, limited access zones by limited access barriers, and normal access zones by normal access barriers. The HVAC system creates and maintains different pressures in the various zones. The lowest pressure is in the restricted access zone so that leakage, if any, is always toward an area of higher contamination potential.

\subsection{VENTILATION SYSTEMS}

The principal risks of plutonium fuel fabrication plants are release and dispersal of plutonium materials. The plant ventilation systems ensure the confinement of plutonium materials during normal and abnormal conditions. These systems consist of fresh air supply, process ventilation 
and exhaust air, associated air heating units, filters, fans, dampers, ducts, fire-fighting devices, control instrumentation, and regulation devices. The air supply system draws in and conditions fresh air and distributes it throughout the plant. A portion of supply air enters the process ventilation system through process enclosures and other components and is removed together with other plant air through the exhaust ventilation system. The exhausted air is filtered through fire-resistant High Efficiency Particulate Absolute (HEPA) filters and discharged through a stack, which allows prompt, adequate dispersion in the event of an accident.

The ventilation systems serve as principal confinement barriers in the multiple confinement barrier system. These systems maintain pressure differentials between building confinement zones and also between the building confinement zones and the outside atmosphere; hence, airflow is from zones of lesser potential for contamination to zones of greater potential for contamination (see Fig. 5.1). 


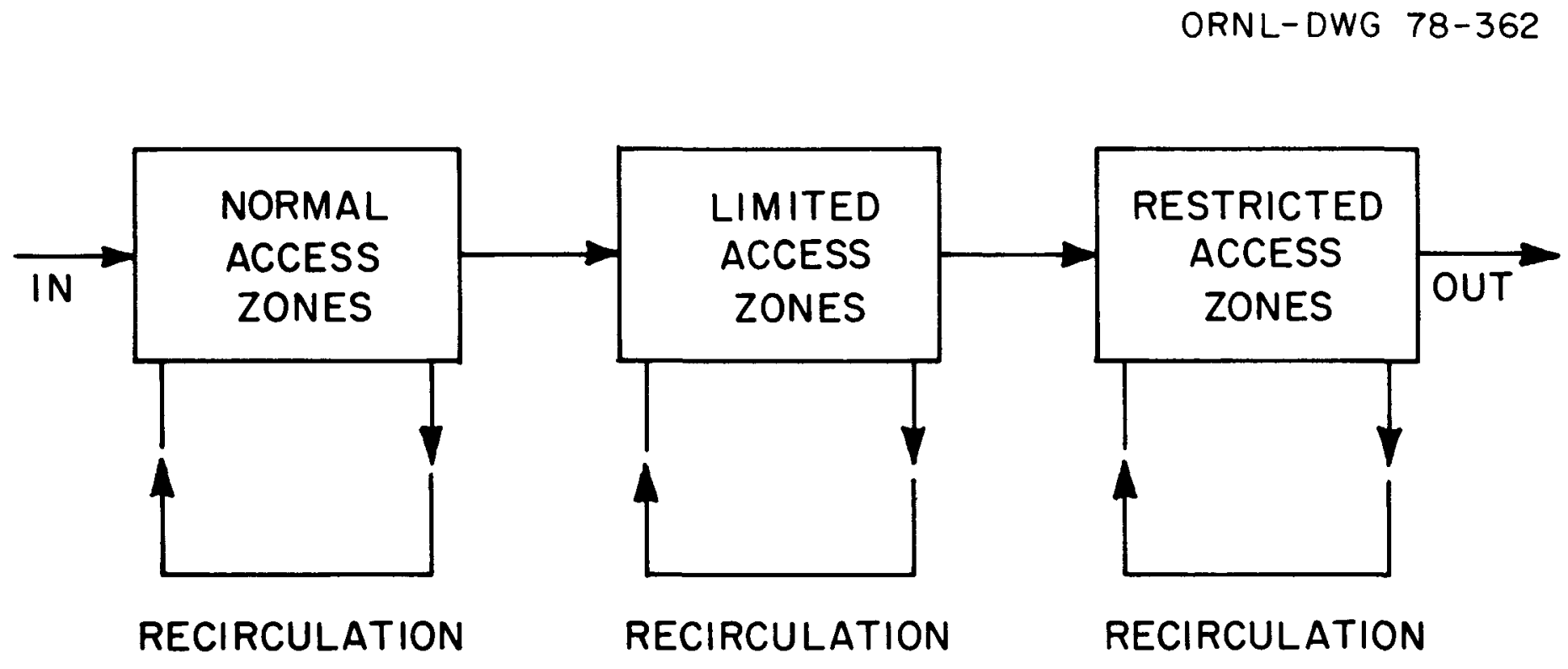

Fig. 5.1. Diagram of Fuel Fabrication Building Airflow. 
-

,

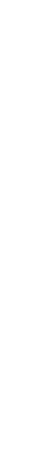




\section{SAFETY AND PROTECTION MEASURES}

\subsection{PROTECTION AGAINST CRITICALITY}

Safety relating to criticality depends on prevention, detection, and personnel evacuation. Each is discussed below.

\subsubsection{Prevention}

The prevention of criticality accidents is based on critically safe equipment and/or critically safe storage. Critically safe equipment is designed with dimensions or materials to completely eliminate criticality accidents. Critically safe storage is an area in which the quantities of fissile materials are limited to well defined safe amounts.

The dimensions of critically safe equipment as well as the authorized amounts of fissile materials in critically safe storage result from safety coefficients and from criticality calculations based on criteria and operating conditions that have been accepted by the nuclear industry.

\subsubsection{Detection and Alarm}

Detection and alarm systems are provided wherever there is a risk of accidental criticality. The criticality detectors are designed to uncover a criticality accident within a very short time. Gamma-ray detection can be used uniformly throughout the system. To avoid false alarms the detection and alarm system provides reliable single detector channels and/or concurrent response of two detectors.

\subsubsection{Evacuation}

If a criticality accident occurs all employees inside the plant have to be evacuated. Alarm units are installed in any area where an individual may be present whose immediate evacuation is essential. The 
plutonium process buildings are designed so that any individual can leave the site of an accident within a well defined time. The thick walls separating the process areas reduce radiation doses received by the operating personne1.

\subsection{DOS IMETRY}

The gel-sphere-pac PWR plutonium fuel refabrication plant is designed, constructed, tested, and operated under rigid quality assurance programs to ensure that operating people are not exposed to internal and external radiation levels that exceed current U.S. regulations. The radiation levels in all accessible areas are controlled to meet such criteria. Plant design and plant monitoring methods are used to ensure that these criteria are met. These methods are discussed below.

\subsubsection{Plant Design}

To avoid any spread of activity (either alpha for plutonium or gamma for spiked fuel) the plutonium handling operations are performed inside equipment that is located within process enclosures and maintained at a negative pressure relative to the adjacent areas of the process building. Furthermore, any suspect or slightly contaminated materials are treated or controlled in ventilated hoods. Outside the process enclosures the plutonium-bearing materials are stored and/or transferred according to well-defined procedures in leaktight devices. The individual protection of the operating personnel in the process areas mainly consists of special clothes, overshoes, and masks, where required.

The exposure of the operating personnel to gamma and neutron irradiation is limited by the use of biological shieldings and remote operating design for the fuel fabrication plant. 


\subsubsection{Plant Monitoring}

Alpha contamination. The surface contamination monitoring consists of routine or special checks in the event of an incident. These checks are made by using appropriate detectors and by measuring either the surfaces or smears with appropriate equipment.

In zones either occupied or to be occupied by workers the atmospheric contamination is continuously monitored and compared with the applicable control level to ensure that workers are not exposed to concentrations exceeding those considered safe.

\subsection{SAFETY AND LICENSABILITY}

Facilities for the refabrication of plutonium LWR recycle fuel must meet regulatory requirements for the protection of operating personnel and the general public. Current U.S. regulations governing fuel processing and fabrication facilities require that the radiation dose at the site boundary from releases from the facility be effectively less than the dose from background radiation.

All structures, systems, and components whose failure might result in doses that exceed the specified limits at the plant boundary must be designated "important to safety" and analyzed for possible failure modes and effects. Al1 structures, systems, and important-to-safety structures, systems, and components constitute the primary containment of radioactive materials. Secondary containment includes limited or noaccess areas and controlled-ventilation areas. Access is restricted by a combination of physical barriers and security measures. All structures, systems, and components important to safety are designed to withstand the effects of natural phenomena likely to occur at the specific facility site. Redundant and/or diverse emergency backup systems maintain uninterrupted operation of all systems related to containment of radioactive materials. Geometry, concentration, or administrative controls are used to prevent criticality. Combustible or explosive 
materials are handled to prevent incidents that might result in radioactive release. Volatile or leachable waste materials receive special treatment and fixation.

The principal difference between a plant fabricating spiked versus nonspiked $(\mathrm{U}, \mathrm{Pu}) \mathrm{O}_{2}$ fuel is that the shielding in the former facility must be increased for fuel process and storage to protect operating personnel. Also, the plant is designed for remote rather than contact maintenance.

\subsection{ENVIRONMENTAL ASSESSMENT}

To be licensed fabrication facilities for plutonium recycle fuel must meet regulatory requirements to ensure that the environment will be protected.

The design of the fuel fabrication facility must adhere to the concept of no releases of radioactive liquids to the environment. Aqueous solutions containing plutonium are treated for plutonium recovery, concentrated, and solidified. Noncondensables are filtered and released as gases.

Plutonium-containing solids are treated for plutonium recovery, converted to a nonleachable form, transferred to steel containers, and stored in a stable geological formation. Solids that contain small amounts of beta and gamma activity are buried at licensed sites. Gases containing radioactive and noxious materials are thoroughly cleaned before release.

In summary, a gel-sphere-pac LWR recycle plutonium fuel fabrication plant contains much less activity and generates much less liquid waste than a Purex LWR fuel reprocessing plant. It should produce less solid and liquid waste than a pellet-process LWR recycle plutonium fuel fabrication plant. It poses no new or unknown activity or solid or liquid waste problems. Therefore, it should not pose any new environmental problems. 


\subsection{BUILDING SAFETY}

In plutonium fuel fabrication plants the main risk to health and safety is the release and dispersal of plutoniun materials caused by fires or explosions. In the reference plant the fire protection system is designed to prevent, detect, extinguish, limit, and control fires and explosions and their concomitant hazards and damaging effects.

\section{5 .1 Prevention}

Plant area. The plant area is sufficiently isolated from the surroundings to limit any damage resulting from a fire originating outside the area. On the plant site sufficiently large physical barriers surrounding the buildings are built to avoid any transmission of a fire occurring in the environs.

Building construction. In general, heat-resistant and noncombustible materials are used practically throughout the reference plant. They are particularly used in the plutonium process areas and in places essential for the functioning of confinement barriers and systems, for controlling radioactive materials, and for maintaining safety control functions.

The structural shells, their supporting members, and the penetrations in these shells surrounding any area where plutonium is handled and where it could be accidentally dispersed are designed so that they will remain standing and continue to act as confinement structures during a well-defined time delay in case of failure of the fire suppression system.

Buildings are separated from each other by open areas. When separate buildings have to be interconnected, long corridors equipped with fire-resistant doors on each end are built.

Isolation of process enclosures. The plutonium materials are processed through interconnected enclosures, which are located in severa1 plutonium areas, as described earlier in Sect. 4. To avoid fire transmission to adjacent process areas, the process enclosures are equipped with fireproof locks, which are opened to allow material 
transfers. Special process enclosures that present high contamination and/or fire risks are operated under inert atmospheric conditions. Gas-handling equipment and flammable materials. Flammable materials are not introduced in buildings where plutonium is processed, except when specifically required for process reasons. The hydrogen required in the process is stored in tanks located outside the buildings. The hydrogen is diluted to a nonexplosive percentage with inert gas before being introduced in the process building.

Except for the small quantities in use solvents and other flammable liquids are stored in a separate building or in an unexposed storage area. Special control is exercised over the handling of flammable, toxic, and explosive gases, chemicals, and materials admitted to the plutonium-handling areas and process enclosures.

Exhaust filter protection. The medium-efficiency room exhaust filters are protected by a spark-arrestor flame trap and a fire-resisting prefilter. The medium-efficiency filters and the HEPA filters installed in the plutonium process building and process enclosure ventilation systems withstand high temperatures during well-defined time delays without any loss of efficiency.

\subsubsection{Fire Detection and Alarm Systems}

Provisions for fire detection and alarm systems consist of fire detectors, signaling devices, and audible and visual indicators in a constantly attended location as well as in other appropriate plant locations.

The types of fire detectors are chosen according to the possible types of fires. The fire detectors are connected to plant-wide fire detection, signal, and alarm systems that can detect and clearly locate the fire within one minute.

Manual fire alarm stations connected to the plant-wide detection systems are installed throughout the plant at immediately accessible places. 


\subsubsection{Fire Suppression Agents and Techniques}

Different fire-fighting techniques, products, and equipment are used in plutonium fuel fabrication plants, depending on the type, size, and the hazard of the potential fire.

Fire hydrants or connection points for hydrants are strategically located around a water distribution loop encircling the buildings site; hence, it is possible to spray all points of the plant area. Wet-pipe conventional automatic sprinklers are used in nonprocess areas of the facility.

For process areas if automatic water sprinkler coverage is used the sprinkler system selected minimizes the quantity of water used, the spread of contamination by water, and the possibility of criticality. Process areas not protected by automatic water sprinklers are protected by other fire suppression agents such as carbon dioxide, high-expansion foam, etc.

An automatic fire-extinguishing system is located in the process enclosures where work entailing serious risk of fire is performed. Depending on the plutonium-bearing materials or liquids being treated inside the process enclosures, fire suppression agents such as highexpansion foam or halogenated organic components are used.

As a supplementary caution portable fire extinguishers filled with various fire suppression agents are distributed throughout the plutonium plant.

\subsection{SAFEGUARDS}

Safeguards is a rapidly changing area in the U.S. Therefore the safeguards descriptions for these plants are based on future proposed systems. In this way the most up-to-date ideas are used in the design of the plants described in this report. 
Safeguards programs have the following goals:

1. to assure that special nuclear materials (SNM) are being adequately

protected,

2. to deter diversion

3. to detect diversion, and

4. to quantify diversion.

Traditionally the first goal has been the function of security organizations that use physical protection systems (PPS) of security guards, barriers, and access controls. The second has usually been the responsibility of SNM management and its materials measurement and accounting systems (MMAS), particularly for covert diversion. The third and fourth have been the responsibility of both organizations.

Detection and quantification of diversion form the basis for the MMAS. The enhanced detection capability of the MMA, relative to historic physical protection systems, would allow safeguards systems to be activated more quickly at lower levels of diversion. This would be most evident in the case of covert multiple diversion of small quantities of special nuclear materials, which might not be detected at all by less specific PPS monitoring.

\subsubsection{Physical Protection System}

The PPS controls personnel entry and exit for the facility and for restricted interior areas. The system includes 1,2

1. automated personnel identification to assure that only authorized people are in restricted areas,

2. entrance and exit SNM monitors and metals and explosive monitors to assure that sensitive materials do not move across barriers that are expected to restrict their passage,

3. presence monitors and closed-circuit television to remotely monitor sensitive areas,

4. passive and active delay systems to slow down an overt external attempt to enter a restricted area, 
5. doorway monitors and alarms to detect movement of people into sensitive areas, and

6. sufficient personnel to respond to an externally generated overt act of a specified size.

The key to the effectiveness of the system is the ability of the SNM monitors to detect small quantities of material. All commercial SNM monitors do this by measuring gamma rays emitted in the monitored space. Regardless of the true source of the gamma rays, it is assumed they come from SNM. Although this assumption might create certain operational problems, it results in highly sensitive monitors.

For unspiked fuel the natural gamma rays monitored are primarily low-energy radiations. Consequently, it would not be difficult to move larger quantities of special nuclear material through the monitored space if the materials were sufficiently shielded. Because of this unguarded monitors require incorporation of metal detectors. Available monitors, that is types used in major airports, have adequate sensitivities.

The automation of these detection capabilities allows the PPS to expand the conventional security functions, such as personnel control, to include control of selected batch-type SNM handling operations.1,2 This arrangement provides more effective protection through remote monitoring and accounting of discrete material items in handling and storage. The concept is applied to those portions of the plants, such as the shipping and receiving areas, where only item accountability is needed. They are outside the continuous flow processing lines where material flow is critical to smooth process operations. Monitored data would be automatically transferred to a computerized safeguards coordination area, bringing the PPS function under the automatic control of the safeguards system.

\subsubsection{Materials Measurement and Accountability System (MMAS)}

To achieve near-real-time (nearly continuous) materials control and accountability the plants are subdivided into physical areas, which have individual SNM accounting. These physical areas are chosen so that all 
nuclear material crossing the unit-process boundary can undergo nondestructive assay and a computation of material balance. The physical areas are chosen to localize the material within a given unit process, both in space and in time. On-line computers are used to cope with the large quantities of data collected over a short time. Materials accounting statistics are calculated and monitored for each unit process. If the value of such a statistic (or set of statistics) exceeds a specified alarm level, the materials control system alerts the appropriate authorities, and investigative action is taken.

The key to the effective development of the MMAS is the recent availability of advanced nondestructive assay (NDA) instrumentation.

These measurements use the natural radiation, neutron-induced fission, or radiation absorption properties of materials in the process stream to determine the identity of the materials and measure their abundance.

of nearly equal importance are direct automated transfer of data from these NDA instruments to a central computer and sophisticated computer programming that does real-time accounting and makes quick diversion assessments from vast quantities of NDA and other process data. Such systems are used in these plants.

\subsubsection{System Structure}

The flow of information, authorization, and control data through and between the safeguards structure and the plant process system is given in Fig. 6.1. It is based on the DYMAC ${ }^{3}$ safeguards system implemented at the Los Alamos Scientific Laboratory.

Safeguards coordination, materials measurements and accounting, and process control coordination are mainly computer-controlled automated functions. The primary technical sophistication of the safeguards system is in the automated coupling of these functions.

The basic data flow is from unit process NDA and associated monitoring sensors in the process line to the MMS. Results of real-time statistical assessments of the data to determine potential diversion 


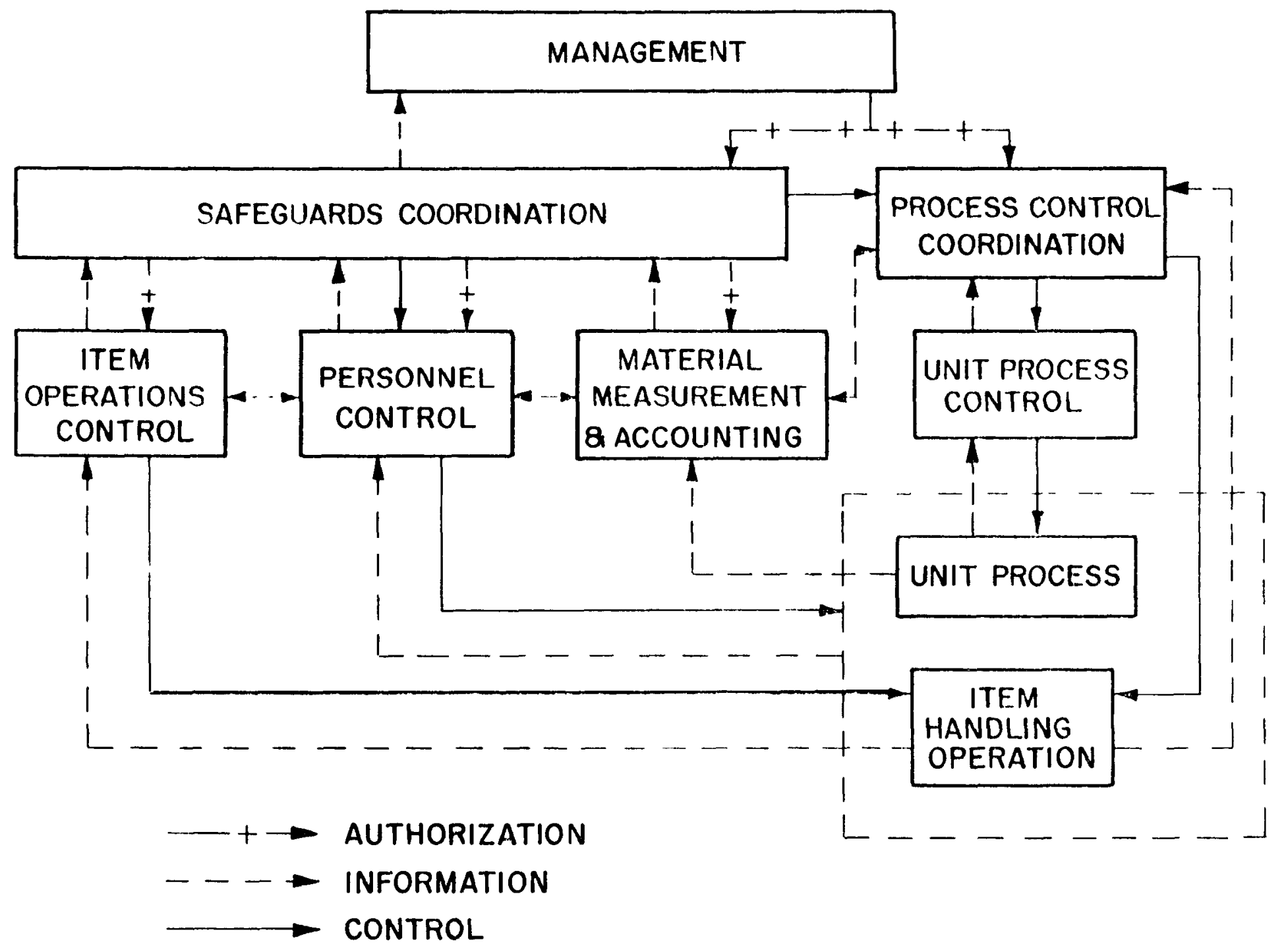

Fig. 6.1. General Structure of Safeguards System. 
are transmitted to the safeguards coordination area and at times to the process control coordination area, depending on the presence of and amount of useful process information in the assessment.

Some head-end and tail-end operations are handled by the physical protection system because items in these operations can be individually identified. Nondestructive assay (NDA) is not done, but items are accounted for by automated data transmission to the safeguards coordination area.

The components of the safeguards system described above are essentially developed. Systems integration, processing, and logic are now being laboratory tested.

\subsection{REFERENCES}

1. L. D. Chapman et a1., Development of an Engineering Safeguards System Concept for a Mixed oxide Fuel Fabrication Facility, SAND 760180 (1976).

2. J. M. de Montmollin and R. B. Walton, "The Design of Integrated Safeguards for Nuclear Facilities," Nucl. Mater. Manage. 5(3): 317-32 (1976).

3. E. A. Hakkila et al., Coordinated Safeguards of Materials Management in a Fuel Reprocessing Plant, Vol. I, LA-6881 (September 1977). 
7. OPERATIONAL PERSONNEL AND ORGANIZATION OF THE PLANT

Operation of the sphere-pac fuel fabrication plant is performed by personnel fully qualified for their respective jobs. All professional personnel have education, training, and experience commensurate with their responsibilities. Training programs are used to a greater or lesser extent for all personnel in the facility, with special emphasis on those involved in special process activities and control of the special nuclear material.

We analyzed the personnel requirements for a sphere-pac PWR fuel plant having a production capacity of $480 \mathrm{tHM} / \mathrm{year}$. We estimated that about 1,100 people are required for the operation of the $(U, \mathrm{Pu}) \mathrm{O}_{2}$ plant in which a spike has been added to the fuel.

The distribution of personnel in the various departments within the plant was based on an assessment of the level of activity and requisite skills of the personnel. We estimated personnel costs, which are presented in Table 7.1. The functions of the various departments indicated in Table 7.1 are generally self-evident, except for plant operations. The plant operations department includes the following functional areas: 1. manufacturing engineering,

2. health physics,

3. security and safeguards,

4. data processing,

5. chemical operations,

6. mechanical operations,

7. maintenance operations,

8. waste management, and

9. shipping and handiing. 
Table 7.1. Annual Personnel Costs for Sphere-Pac Plant $a$

\begin{tabular}{|c|c|c|}
\hline \multirow{2}{*}{ Department } & \multicolumn{2}{|c|}{$\mathrm{RO} / \mathrm{RM}^{b}$} \\
\hline & Fixed & Variable \\
\hline General Management & $\$ 80$ & \\
\hline Design Engineering & 180 & 640 \\
\hline Projects & 60 & 130 \\
\hline Finance & 60 & 280 \\
\hline Purchasing and Personnel & 60 & 510 \\
\hline Medical & 60 & 180 \\
\hline Plant Operations & 1500 & 16,190 \\
\hline Quality Assurance & 300 & 2,700 \\
\hline TOTALS & $\$ 2300$ & $\$ 20,630$ \\
\hline
\end{tabular}

Includes employer cost such as FICA, taxes, and insurance in thousands of dollars.

$b$ Remote operation and remote maintenance for a spiked-fuel plant. 


\section{GENERAL STATUS OF TECHNOLOGY}

The development of sphere forming and sphere-pac technology is behind pellet technology. The sphere forming and sphere-pac concepts originated in the U.S. almost 20 years ago (as "sol-gel"), and active development was pursued in this country until 1972. Ge1-sphere-pac technology at that time was thoroughly documented. $1-4$ However, several foreign countries, including the Netherlands, the United Kingdom, Germany, and Switzerland, have continued their sphere fuel development and have made significant contributions. 5-8 The U.S. gel-sphere-pac work was reinitiated in June 1977.

The status of development for the two major ge1-sphere-pac areas (ge1-sphere preparation and sphere-pac loading) is roughly the same. Gel-sphere preparation has received more attention for a longer period than sphere-pac loading, but it is significantly more complex. Therefore, their remaining overall development needs are estimated to be about equa1.

A discussion of development status and needs is conveniently organized along two standards: the scale of operation and the various functional systems involved. For processes aimed eventually at the design, construction, and successful operation of a commercial facility the following sequence is both realistic and representative of the actual number of development stages needed:

1. cold lab - to demonstrate process feasibility with low-activity substitutes;

2. hot lab - to verify process feasibility with highly gamma-active materials;

3. cold engineering - to demonstrate equipment concepts under nonradioactive conditions;

4. hot engineering - to verify equipment concepts under remote, highly gamma-active conditions; and

5. cold prototype - to demonstrate full-scale components, including integrated and/or remote operation for the more complex steps. 
In general, cold-lab work provides the basis for both hot-lab and cold-engineering work. The last two together provide the basis for both hot-engineering and cold-prototype work, which in turn provide a solid basis for a commercial-scale facility. Fuel samples for irradiation testing would normally be produced during all stages of development. In the U.S. and Europe some irradiation testing has been done with test rods of various lengths and with generally favorable results; additional tests are under way in Europe and are in preparation in the U.S.

Depending on the fuel cycle these basic research and development stages might well be augmented by operation of a pilot plant facility in which actual fuel elements are produced. Such a facility would have a production capacity of approximately $10 \%$ of the commercial facility discussed in this report. The costs of construction and operation of the pilot plant would be considered part of the research and development required.

A demonstration plant (assumed to have approximately $30 \%$ of the commercial scale plant described here) is typically the next step before the design and construction of a full-scale commercial plant. While the design studies through conceptual design are logically part of the research and development activities, the cost of detailed design, construction, and operation are considered demonstration costs; most of these will be recovered by the sale of products. Thus, we have chosen to identify these activities separately.

For this generic plant we estimated the schedule for the independent development of the sphere-pac process, as shown in Fig. 8.1. The initial program plan in this schedule is assumed to start any time after FY 1979.

While the above breakdown of activities provides a reasonable schedule, the technology status, development requirements, and costs can best be addressed by the primary process functional areas, as defined in Fig. 3.1. Sections 8.1 and 8.2 discuss these for the generic plant. Modifications required for specific reactor fuel cycles are covered in Sect. 9. Table 8.1 qualitatively summarizes the current status of technology. 
ORNL-DWG 78-21434R

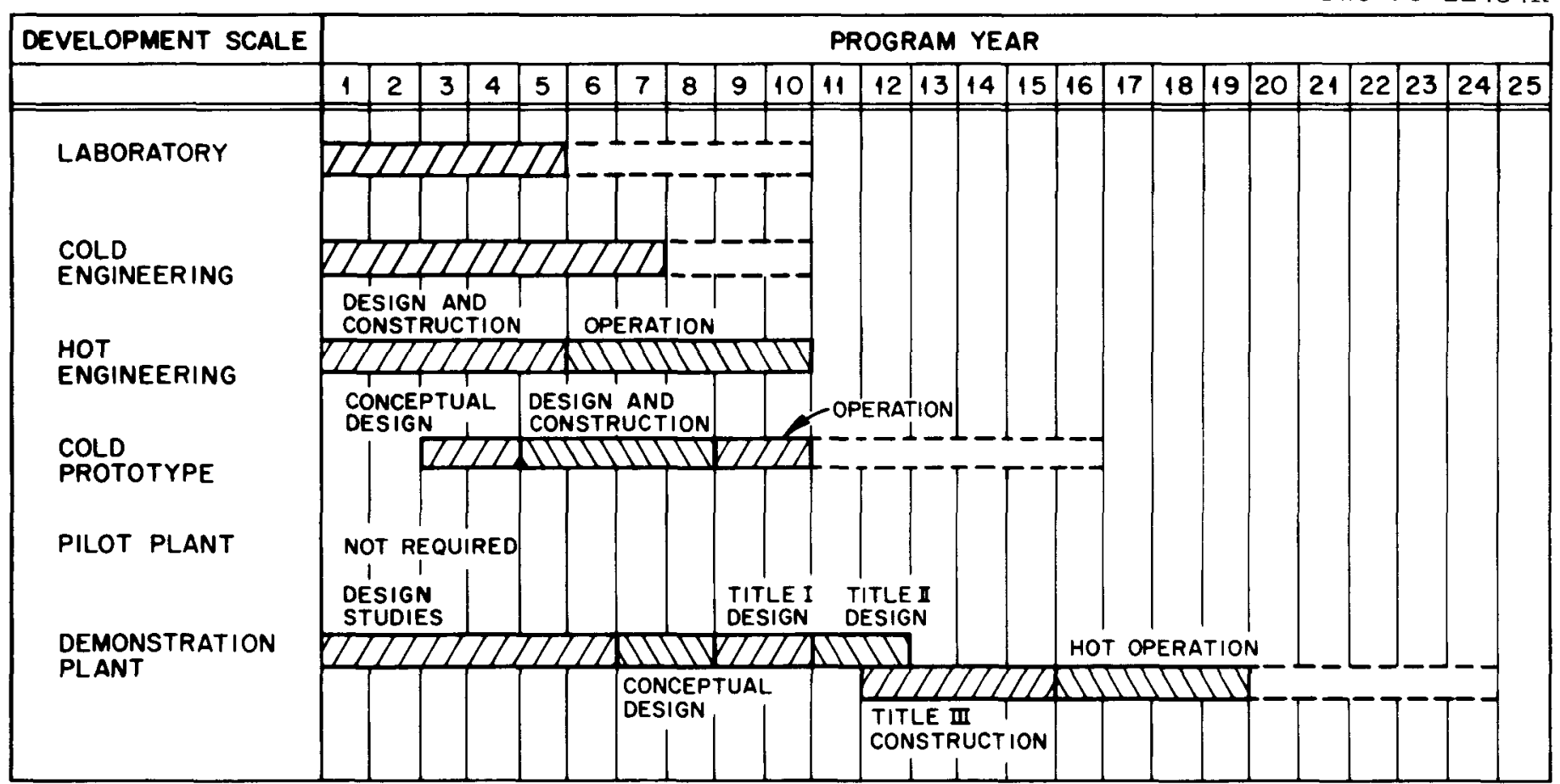

Fig. 8.1. Summary Schedule for Research and Development of Ge1-Sphere-Pac Fuel Fabrication. 
Table 8.1. Status of Technology Summary for Sphere-Pac Fabrication of LWR (U,Pu) $\mathrm{O}_{2}$ Spiked Fue1 $\mathrm{S}^{\mathrm{a}}$

\begin{tabular}{|c|c|c|c|c|c|c|c|c|c|}
\hline $\begin{array}{c}\text { Functions, Processes, or Equipment } \\
\text { from Functional Flow Sheet }\end{array}$ & $\begin{array}{c}\text { New } \\
\text { Concept }\end{array}$ & $\begin{array}{l}\text { Cold } \\
\text { Lab }\end{array}$ & $\begin{array}{l}\text { Hot } \\
\text { Lab }\end{array}$ & $\begin{array}{l}\text { Cold } \\
\text { Eng. }\end{array}$ & $\begin{array}{l}\text { Hot } \\
\text { Eng. }\end{array}$ & $\begin{array}{l}\text { Cold } \\
\text { Prototype }\end{array}$ & $\begin{array}{l}\text { Pilot } \\
\text { Scale }\end{array}$ & Demonstration & Commercial \\
\hline \multicolumn{10}{|l|}{ 1.0 Receiving and Storage } \\
\hline $\begin{array}{ll}1.1 & \text { Canister Design } \\
1.2 & \text { Weighing } \\
1.3 & \text { Samp1ing } \\
1.4 & \text { Remote Handling }\end{array}$ & $\mathrm{N}$ & $\mathrm{C}$ & & $\begin{array}{l}\mathrm{N} \\
\mathrm{P} \\
\mathrm{P}\end{array}$ & $\begin{array}{l}\mathrm{N} \\
\mathrm{N} \\
\mathrm{N}\end{array}$ & $\begin{array}{l}\mathrm{N} \\
\mathrm{N} \\
\mathrm{N} \\
\mathrm{N}\end{array}$ & & $\begin{array}{l}\mathrm{N} \\
\mathrm{N} \\
\mathrm{N}\end{array}$ & \\
\hline \multicolumn{10}{|l|}{2.0 Fuel Production } \\
\hline $\begin{array}{ll}2.1 & \text { Sampling } \\
2.2 & \text { Calcination } \\
2.3 & \text { Sintering } \\
2.4 & \text { Microsphere Inspection } \\
2.5 & \text { Interim Storage } \\
2.6 & \text { Pneumatic Transport }\end{array}$ & & $\begin{array}{l}\mathrm{C} \\
\mathrm{P} \\
\mathrm{P} \\
\mathrm{C} \\
\mathrm{C} \\
\mathrm{C}\end{array}$ & $\begin{array}{l}\mathrm{P} \\
\mathrm{P} \\
\mathrm{P}\end{array}$ & $\begin{array}{l}\mathrm{P} \\
\mathrm{N} \\
\mathrm{N} \\
\mathrm{P} \\
\mathrm{C} \\
\mathrm{P}\end{array}$ & $\begin{array}{l}\mathrm{N} \\
\mathrm{N} \\
\mathrm{N} \\
\mathrm{N} \\
\mathrm{N} \\
\mathrm{N}\end{array}$ & $\begin{array}{l}\mathrm{N} \\
\mathrm{N} \\
\mathrm{N} \\
\mathrm{N} \\
\mathrm{N} \\
\mathrm{N}\end{array}$ & & $\begin{array}{l}\mathrm{N} \\
\mathrm{N} \\
\mathrm{N} \\
\mathrm{N} \\
\mathrm{N} \\
\mathrm{N}\end{array}$ & \\
\hline \multicolumn{10}{|l|}{ 3.0 Fuel Rod Fabrication } \\
\hline 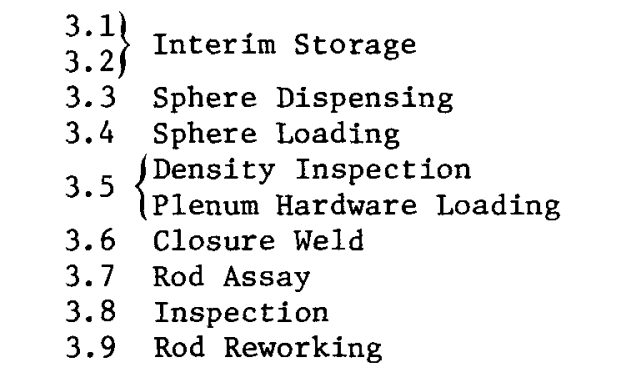 & & $\begin{array}{l}\mathrm{C} \\
\mathrm{P} \\
\mathrm{P} \\
\mathrm{P} \\
\mathrm{P}\end{array}$ & $\mathrm{N}$ & $\begin{array}{l}\mathrm{C} \\
\mathrm{P} \\
\mathrm{P} \\
\mathrm{P} \\
\mathrm{N} \\
\mathrm{P} \\
\mathrm{P} \\
\mathrm{N} \\
\mathrm{N}\end{array}$ & $\begin{array}{l}\mathrm{N} \\
\mathrm{N} \\
\mathrm{N} \\
\mathrm{N} \\
\mathrm{N} \\
\mathrm{N} \\
\mathrm{N} \\
\mathrm{N}\end{array}$ & $\begin{array}{l}\mathrm{N} \\
\mathrm{N} \\
\mathrm{N} \\
\mathrm{N} \\
\mathrm{N} \\
\mathrm{N} \\
\mathrm{N} \\
\mathrm{N} \\
\mathrm{N}\end{array}$ & & $\begin{array}{l}\mathrm{N} \\
\mathrm{N} \\
\mathrm{N} \\
\mathrm{N} \\
\mathrm{N} \\
\mathrm{N} \\
\mathrm{N} \\
\mathrm{N} \\
\mathrm{N}\end{array}$ & \\
\hline \multicolumn{10}{|l|}{4.0 Fue1 Element Assembly } \\
\hline $\begin{array}{ll}4.1 & \text { Rod Storage } \\
4.2 & \text { Assembly } \\
4.3 & \begin{array}{l}\text { Inspection } \\
\text { Packaging }\end{array}\end{array}$ & $\mathrm{N}$ & & & $\begin{array}{l}\mathrm{N} \\
\mathrm{N} \\
\mathrm{N} \\
\mathrm{N}\end{array}$ & & $\begin{array}{l}\mathrm{N} \\
\mathrm{N} \\
\mathrm{N} \\
\mathrm{N}\end{array}$ & & $\begin{array}{l}\mathrm{N} \\
\mathrm{N} \\
\mathrm{N} \\
\mathrm{N}\end{array}$ & \\
\hline 5.0 Scrap Handling & & $\mathrm{N}$ & $\mathrm{N}$ & $\mathrm{N}$ & & $\mathrm{N}$ & & $\mathrm{N}$ & \\
\hline 6.0 Waste Treatment & & $\mathrm{N}$ & $\mathrm{N}$ & $\mathrm{N}$ & & $\mathrm{N}$ & & $\mathrm{N}$ & \\
\hline
\end{tabular}

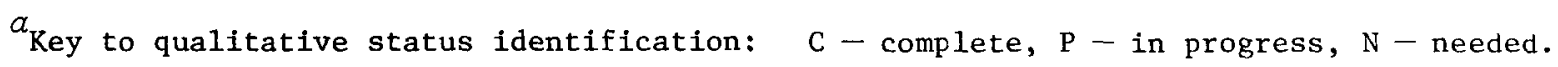




\subsection{TECHNOLOGY STATUS AND DEVELOPMENT REQUIREMENTS BY PROCESS FUNCTIONS}

Only the technology status of the sphere-pac process and its development requirements are specifically addressed in this report. However, because of the close relationship to the conversion process at a reprocessing plant, which provides the basic spherical starting material, a discussion of this process and its status has been included in the Appendix. The intimate interaction of the conversion process and the fuel production functions is recognized in the following analysis. Two recent reports have assessed the ge1-sphere-pac fuel for Fast Breeder Reactors, 9,10 and much of the following information has been extracted from those reports.

In the following sections we discuss the functional areas, as shown in Fig. 3.1. A further subdivision could be by an area of sphere-pac process functions through the completion of fuel rod fabrication and by a generic area involving the rod inspection and fuel element assembly functions, which are applicable to all metal clad oxide fuel regardless of the fuel material form.

\subsubsection{Receiving and Storage}

\subsubsection{Functional Definition}

Critically safe vessels with two sizes of dried fissile containing gel spheres are received as feed for the refabrication facility. To provide proper quality assurance and material accountability these containers must be weighed and their accompanying sample must be retrieved. These shipping vessels, which also serve as in-plant feed storage vessels, must be designed to facilitate convenient movement and storage. Fittings must be provided that allow rapid connection and discharge of particles in the facility transfer system. 


\subsubsection{Technology Status}

Criticality data are available for guidance in the design of safe storage vessels. Concepts for handling and emptying storage hoppers have been developed in unreported HTGR fuel particle handling development work at ORNL. Computer techniques are available to handle the real-time inventory of storage containers.

\subsubsection{Required Development}

The major development task is the identification of a remote weighing system for full and empty shipping vessels. Development of a computer-assisted canister retrieval system is also required.

\subsubsection{Fuel Production}

\subsubsection{Functional Definition}

This task converts dried fissile-containing spheres into near theoretically dense spherical feed for the rod loading process. The main concerns of the task are the heat treatment of the particles and the post treatment characterization. Heat treatment involves: (1) calcination, to eliminate excess volatiles; (2) sintering, to densify the material; and (3) reduction, to produce the desired oxygen-tometal ratio. Since sintering and reduction ordinarily occur simultaneously, these two steps will be considered one operation.

It is assumed that the fertile fines will be received as sintered spheres, which will not require further processing in this work task.

\subsubsection{Technology Status}

Spheres of $\mathrm{ThO}_{2}$ are easily sintered to densities in excess of $99 \%$ of theoretical at temperatures below $1450^{\circ} \mathrm{C}$. Urania and urania-plutonia spheres of various compositions have been routinely sintered to densities 
greater than $95 \%$ at $1550^{\circ} \mathrm{C}$ or below. Recently broth-derived urania spheres have been routinely sintered to over $99 \%$ T.D. However, sphere sintering has not been demonstrated for all fuel compositions being considered. Most experience is with batch operations. Plutonia experience is limited to batch sizes of several hundred grams, except for recent unreported British work that has used somewhat larger batches.

In general, most of the proposed "recipes" for producing a dense sphere of given composition vary widely among the different preparation schemes. Indeed, even within a given process (e.g., the KEMA* internal gelation process) the times, temperatures, rates, and atmospheres reportedly used for sintering vary from one report to another. This largely results from the lack of basic knowledge of the complex sintering processes occurring within the spheres; that is, whenever another sphere forming, washing, or drying process variation occurs, unanticipated changes may be required in the calcination and sintering steps.

Hence, in attempting to devise densification routines one must consider the phenomenology of the process and try to control it to one's advantage. To this end it is necessary to analyze the observable internal processes occurring in the spheres during heat treatment. These are: elimination of volatiles $\left(\mathrm{H}_{2} \mathrm{O}, \mathrm{NH}_{3}, \mathrm{NO}_{3}{ }^{-}\right.$, organic compounds), crystallite rearrangement, crystal growth, phase changes (e.g., $\mathrm{UO}_{3} \rightarrow \mathrm{U}_{3} \mathrm{O}_{8} \rightarrow \mathrm{UO}_{2}$ ), initial stage sintering, and

final stage sintering.

Unfortunately, these phenomena are not separable during the processing, as several may be occurring simultaneously. However, elimination of volatiles and phase changes are easily followed through use of differential thermal analysis, thermogravimetric analysis, of $f-g a s$ analysis, and x-ray diffraction. Normally, careful heating in a controlled atmosphere will eliminate most of the volatile constituents at temperatures be 1 ow $600^{\circ} \mathrm{C}$.

*Keuring van Electrotechnische Materialen at Arnhem, Netherlands. 
The initial stage of sintering of $\mathrm{ThO}_{2}$ has been studied by Bannister ${ }^{11}$ and of $\mathrm{UO}_{2}$ by Suzuki et al.,12,13 Landspersky et a1.,14,15 and Breschi et al.16 Bannister found that for $\mathrm{ThO}_{2}$ gel produced by the ORNL water-extraction technique, the first $4 \%$ of linear shrinkage was solely from elimination of volatiles. After this the remainder of the shrinkage was controlled by grain boundary diffusion of thorium. Particle shape did not change on sintering to $900^{\circ} \mathrm{C}$ (in air), but extensive crystal growth occurred; for example, $6.0 \mathrm{~nm}$ as received grew to $30 \mathrm{~nm}$ at $900^{\circ} \mathrm{C}$. On the other hand, Suzuki et al.12,13 found that the initial stage of sintering $\mathrm{UO}_{2}$ sol-gel material proceeded in two steps: up to $675^{\circ} \mathrm{C}\left(\right.$ in $\left.\mathrm{H}_{2}\right)$ the shrinkage was proportional to time, implying a grain rearrangement through boundary sliding (plastic flow), and from about 750 to $800^{\circ} \mathrm{C}$ volume diffusion controlled the rate. Above $800^{\circ} \mathrm{C}$ grain growth occurred normally to about $1080^{\circ} \mathrm{C}$ where grain size increased abruptly. The shape of the grains changed from spherical to polyhedral at this temperature. Above $1080^{\circ} \mathrm{C}$ normal grain growth continued and sintering proceeded.

Landspersky's 15 preliminary investigations covered $\mathrm{UO}_{2}$ produced by the KEMA process and KFA*Jülich's H-Process. Calcining in air led to removal of the majority of volatiles in the range 200 to $250^{\circ} \mathrm{C}$, which was considered to be the critical range for crack formation. If cracks were not formed in this range, there was no cracking on sintering. Spheres produced by these two processes consisted of $\mathrm{UO}_{3}$ after heating to 360 to $450^{\circ} \mathrm{C}$ in air. However, if the heating rate was too rapid and the material pore structure prohibited rapid release of the volatiles, some reduction occurred. In air $\mathrm{UO}_{3}$ was stable to 510 to $570^{\circ} \mathrm{C}$.

Landspersky's sintering study 17 on the same materials in $\mathrm{Ar}-4 \% \mathrm{H}_{2}$ elucidated an important point: With particles that had been air dried to $220^{\circ} \mathrm{C}$, then sintered in $\mathrm{Ar}-4 \% \mathrm{H}_{2}$, U(VI) was reduced to U(IV) at temperatures as low as $280^{\circ} \mathrm{C}$. If calcination in air or inert atmosphere to $\mathrm{U}_{3} \mathrm{O}_{8}$ was allowed before reduction a different microstructure was formed, resulting in different sintering rates for the materials. Apparently

* Kernfor schungsanlage 
above about $600^{\circ} \mathrm{C}$ sintering begins in either the $\mathrm{UO}_{2}$ or $\mathrm{U}_{3} \mathrm{O}_{8}$, whichever is present. In $\mathrm{UO}_{2}$ this occurs with pore elimination and shrinkage. The originally formed pore shape remains unchanged, and only the pore volume decreases. On the other hand, in $\mathrm{U}_{3} \mathrm{O}_{8}$ the porosity is redistributed, with pore size shifting to larger diameter as fine porosity is eliminated. Once formed the larger pores are retained. Several groups ${ }^{18-20}$ have used this technique to prepare sintered spheres of controlled porosity, mainly by varying the maximum calcination temperature to vary the amount or structure of $\mathrm{U}_{3} \mathrm{O}_{8}$ formed.

Final-stage sintering involves the elimination of closed porosity coincident with normal grain growth. All the materials being considered will sinter by the same type of process, which is controlled by mass transfer - usually diffusion of the cation along grain boundaries. The principal determinant of final density will then be the microstructure produced by the preceding steps. That is, given the appropriate temperature and time materials containing fine porosity and small grain size will sinter to high density. However, if large pores and/or large grains have been left in the structure, the densification will be impeded, as noted in the work on material with controlled porosity.

Considerable experience is available concerning the sintering and stoichiometry control of $(\mathrm{U}, \mathrm{Pu}) \mathrm{O}_{2-x}$ sol-gel-derived spheres. ${ }^{3}$ Generally ( $\mathrm{U}, \mathrm{Pu})_{2}$ sintered to densities greater than $95 \%$ T.D., with the remaining pores being rather large and presumably introduced during sphere forming rather than resulting from pore agglomeration during sintering. With improved sol or broth and better sphere forming higher densities are possible.

Substoichiometry was controlled in ( $\mathrm{U}, \mathrm{Pu}) \mathrm{O}_{2-x}$ batches of several hundred grams. The rate of reduction of the mixed oxides by hydrogen in argon was found 21 to be controlled by the removal of water vapor from the furnace by the gas stream; the moisture content of the furnace atmosphere is often controlled by the previous history of the furnace and not by the incoming gas.

Most of the work described in the literature was performed on small amounts of material in batch operations. However, scaling of the 
sintering processes to larger batches and continuous operation has been done with only minor problems occurring. Two problems are: (1) difficulty in controlling heat released in exothermic reactions on calcination and (2) difficulty in obtaining uniform temperatures and gas atmosphere circulation through the mass of spheres. These problems have been attacked through use of fluidized-bed techniques or use of thin beds. A large batch dryer and calciner allowing semicontinuous operation was developed and applied at ORNL for remote use. 22 For larger throughput operation a continuous vertical-tube moving-bed calciner was developed by ORNL. 23 In this device the temperature profile along the tube was controlled so that the moving charge underwent the correct temperature-time program. The countercurrent flow of gas up the tube provided excellent use of the atmosphere. A further advantage was that interparticle sticking, a potential problem particularly with fines, could be avoided. A similar device was used in a SNAM* process pilot plant. 24, 25

The KEMA process has been scaled up to pilot-plant operation. 26 Calcination was performed in shallow beds in a large forced-convection furnace. The particles were then transported in boats though a furnace, which provided atmosphere control and the required time-temperature profile. The same sort of apparatus was employed for $(\mathrm{U}, \mathrm{Th}) \mathrm{O}_{2}$ by Hobeg and $\mathrm{KFA}^{27}$ in their production plant, turning out $4 \mathrm{~kg} \mathrm{HM} / \mathrm{h}$. The SNAM 24, $258-\mathrm{kg} / \mathrm{d}$ pilot plant used a moving-bed calciner (as noted above) followed by a continuous-throughput horizontal furnace (pusher-type). Apparently particle sticking was not a problem during sintering. Thus, large batches of $\mathrm{UO}_{2}, \mathrm{ThO}_{2}$, or $(\mathrm{Th}, \mathrm{U}) \mathrm{O}_{2}$ can apparently be readily produced on a semicontinuous or continuous basis with no real problems by use of available technology. Preparation of substoichiometric $(\mathrm{U}, \mathrm{Pu}) \mathrm{O}_{2-\infty}$ requires extremely good sphere-sintering atmosphere contact to maintain a suitably high reduction potential to promote reduction, and thus scale-up for $(\mathrm{U}, \mathrm{Pu}) \mathrm{O}_{2-x}$ might require fluidized beds or other means for providing good gas-solid contact.

*SNAM Progetti S.p.A., Italy 
Analysis of the sintered particles is necessary to confirm that they will yield acceptable fuel rod density. Contact or glove-box laboratory-scale techniques have been used in the past to thoroughly characterize spheres of numerous compositions, including (U, $\mathrm{Pu}) \mathrm{O}_{2-x}$. With only a few exceptions this equipment was not remotely operable and not suitable for on-line inspection. Except for the fines sphere size distribution can currently be measured automatically by an analyzer developed for remote operation.

The following attributes of sintered particles must be determined.

\section{Density}

Since any porosity in the sintered spheres lowers the fuel rod smear density, the spheres need to be as dense as practical. The pertinent density value is the geometric density. This is readily determined on spheres larger than about $50 \mu \mathrm{m}$ in diameter by immersion in mercury at about $500 \mathrm{kPa}(75 \mathrm{psi})$. For finer spheres the void spaces between particles are very small so that higher pressures are required to penetrate them with the mercury. The key is to completely surround the particle with mercury but not penetrate any sphere porosity. The procedure is presently done in only a manual mode.

Other techniques include immersion in water or other liquids. However, care must be exercised in the use of the data since pores of nanometer size will be penetrated and falsely high density values obtained.

Another technique is size measurement (either by optical or electronic means) of a given batch along with weighing. This process is ideally suited for automation to the production line since particles can be continuously removed, measured, and returned to the line, yielding density and size data simultaneous 1 y. 28

\section{Size and Shape}

Particle size may be measured in numerous ways: sedimentation, light blockage, microscopy, radiography, etc. However, shape is only 
measured optically by comparing diameters in different orientations from a photograph. Should there be any nonspherical particles, they may be separated out by use of a tilted vibrating plate. This technique is not useful for fines smaller than about $100 \mu \mathrm{m}$, and no shape separation technique is available for these.

\section{Chemistry}

Standard techniques for chemical analysis of nuclear fuel materials have been developed, especially for pellet fuel. These can be applied to sol-gel sphere fuel since it is also a sintered solid material. However, additional specifications will be required for (U, $\mathrm{Pu}) \mathrm{O}_{2}$ fuels for breeder applications.

\section{Strength}

Loading sphere-pac fuel into full-length rods will impose considerable stress upon the spheres so that a high strength will be required. Strength is commonly determined by loading a sphere in compression between two flat steel plates. An ORNL modification 29 involves use of a steel holder plate drilled with 64 flat-bottom holes into which the particles are placed. A pin with flat ends is then put into the hole and the load applied. Crushing strength (actually load) is read from a strip-chart recorder. An automated remotely operable device for measuring crushing strength of spheres is currently being developed for HTGR fuels.

\section{Microstructure}

Particle microstructure is determined microscopically by standard mounting and polishing techniques coupled with optical or microprobe examination or by fracturing and electron microscopic examination. Several papers $12,16,30,31$ have been published illustrating the use of these techniques with sol-gel spheres.

Parameters of interest in microstructural evaluation include grain shape, size, and distribution; porosity shape, size, location, and distribution; and the presence of defects such as voids and cracks. 
8.1.2.3 Required Development

The sintering of spheres of the required composition(s) must be developed for the specific gel process(es) selected. Variables that must be considered are heating rate, sintering temperature and time, and calcining and sintering atmosphere. Development of a sintering process requiring temperatures no greater than about $1450^{\circ} \mathrm{C}$ would be of considerable benefit in that simpler more reliable heating elements could be used. While sintering furnace development can draw from previous pellet work, there may be special requirements for providing improved gas-sphere contact; for example, a fluidized bed might be advantageous. A suitable continuous or batch remote furnace with high material throughput remains to be developed.

It has been shown ${ }^{3}$ with $(\mathrm{U}, \mathrm{Pu}) \mathrm{O}_{2-x}$ sol-gel spheres that stoichiometry, moisture, and gas content can be controlled to currently specified limits for pellet fuels. However, in this earlier work the product was always handled in inert-atmosphere glove boxes following sintering. Numerous equipment items can be simpler and more reliable if they can tolerate some exposure to air and moisture. Therefore, it is important to determine the exact degree of precaution necessary in the subsequent handling of sintered spheres.

Suitable remotely operable furnaces for calcination and sintering do not exist. Similar furnaces, such as the one planned for coating of HTGR fuel particles, are at an advanced stage of development. In addition to using minimum floor space the required furnace must have atmosphere control, either oxidizing or reducing for the calcining furnace and reducing for the sintering furnace. Automated particle handling must be an integral part of such furnace systems. Particle handling schemes must be developed to efficiently charge the furnaces and to unload the particles after sintering. Samples must be automatically extracted during these operations to perform analyses on each batch. A faster technique is needed for size and shape analyses of fines. Faster techniques are needed for residual gas and moisture 
determinations. Improved techniques are needed for determination of density and oxygen-to-metal ratio. Improved specifications for sphere shape and microstructure are required.

\subsubsection{Fue1 Rod Fabrication}

\subsubsection{Functional Definition}

This functional area receives high-quality sintered spheres of three sizes as well as the hardware required for fuel rod manufacture. Spheres and internals are loaded into the cladding tubes, and the tubes are welded closed. Provisions are included for the rework of fuel rods that fail to pass the stringent density, assay, and physical inspections, which are also included in the fabrication task.

\subsubsection{Technology Status}

This task must develop the equipment technology needed to remotely operate complex equipment including particle dispensers, particle blenders, fuel rod vibrators, density scanners, end-plug welders, assay devices, and physcial inspection stations.

We are now evaluating suitable dispensers, blenders, and vibration techniques. Specialized equipment must be designed and tested for the dispensing and blending operations because of the special characteristics of the spheres. Commercially available devices do not yield optimal results. Several blending techniques have been reported in sphere-pac and vi-pac literature. Hauth ${ }^{32}$ apparently used conventional powder blending techniques to prepare vi-pac material. He then transferred a weighed amount of fuel to a small conveyor belt, which was driven by a variable-speed motor. This permitted the rod loading rate to be closely controlled. Hauth indicated that with a suitably modified feeder more than 20 rods could be compacted simultaneously. In another report hauth ${ }^{33}$ stated that both vibratory feeders and small conveyors had been used for rod filling, but that the latter device offered a 
possible advantage by allowing better control of particle-size distribution of material just before it entered the rod.

Evans and Millman 34 also used a conveyor belt to prevent segregation in their vi-pac study. They loaded each of the size fractions of powder into separate long rectangular boxes of uniform length and width. The boxes were then emptied onto a stationary conveyor belt so that the various sizes were uniformly distributed along the conveyor. Movement of the conveyor caused simultaneous loading of the different size fractions.

Currently, Oak Ridge National Laboratory is carrying out the largest U.S. development effort on the fabrication of fuel rods by the sphere-pac process. ${ }^{35}$ This program is directed toward both LWR and FBR fuel geometries. Loading has been studied by using closely sized spheres over a working range of from 20 to $1400 \mu \mathrm{m}$. Simultaneous loading of three particle sizes is accomplished with newly developed blending techniques. Published experimental results show that $85 \%$ smear density is at tainable for 5.1-mm-ID (0.200-in.) cladding (FFTF design) by using particle sizes of 1200,300 , and $30 \mu \mathrm{m}$ in a blend of 58,20 , and $22 \%$, respectively. Higher smear densities suitable for LWR designs have been achieved with proper cladding size and particle selection.

Before being loaded into the rod, spheres will have to be conveyed from the sintering area to the fuel rod loading station. For such transfers a pneumatic conveying system appears to be ideal. This type of conveying provides the greatest flexibility in the routing of transfer lines and the resulting easing of restrictions on the placement of process equipment. The system itself is amenable to scale-up; kilograms per minute can be pneumatically transferred. Flow indicators, pressure monitors, and hopper level indicators provide adequate feedback for reliable and efficient operation. Operating parameters can be readily determined. Conveying in the dilute phase - where all the material is entrained in the gas stream, with no settling out - can be accomplished with low pressure [less than $0.1 \mathrm{MPa}$ (15 psi)] and moderate flow [less than 5 liters/s $(10 \mathrm{scfm})$ ]. Also, the transfer hoppers and lines constitute a closed system. Thus, use of argon as the motive gas virtually eliminates oxidation and moisture pickup. 
Extensive development and operating experience have been acquired under the HTGR Fuel Recycle Development Program at ORNL on pneumatic conveying of nuclear fuel spheres. 36 This program has also involved the development of auxiliary sphere handling equipment, such as samplers, 37 weighers, and level sensors. The equipment has been developed with the ultimate goal of totally remote operation.

After the fuel is loaded into the cladding tube and compacted, the remainder of the fabrication process should be very similar to pellet fuel fabrication processes. The remaining steps include: (1) fuel rod outgassing, (2) placement of plenum spring, and (3) end-plug welding.

Fuel rod outgassing removes moisture and other sorbed gas contaminants from the fuel. Hauth ${ }^{35}$ chose to outgas fuel particles immediately before loading by holding them in a vacuum at $250^{\circ} \mathrm{C}$ for $2 \mathrm{~h}$. olsen et al. 38 outgassed the fuel rod after the fuel had been compacted. This was done by evacuating the rod while heating at $110^{\circ} \mathrm{C}$ for $30 \mathrm{~min}$. Most sphere-pac irradiation test rods are currently loaded while inside a helium-filled glove box. Pechin ${ }^{39}$ has described analytical methods for measuring moisture and sorbed gas content of sphere-pac fuel. Moisture content in the fuel of less than $10 \mathrm{ppm}$ was successfully measured with this technique.

Both pellets and particulate fuels can be held in place through the use of plenum springs. To restrain a sphere-pac bed a spacer disk made of alumina or thoria is placed on top of the fuel column to transmit the spring pressure. For the fabrication of irradiation test rods ORNL researchers used thoria spacers and small pieces of outgassed ceramic fiber (Fiberfrax) to prevent fuel movement during handling and shipping. 40

The procedure used for welding the top end plug should be identical for both pellet and sphere-pac fuel. Welding technology is wel1 advanced. Of course, atmosphere control is important during welding to prevent contamination and possible corrosion during irradiation.

With the completion of the end-plug welding step, the fabrication process is complete, and the assembled fuel rod is moved to an inspection station. Some inspections, such as gamma scan and heavy metal assay, are amenable to remote oepration; 41 most are not and would require 
significant development to enable the inspection to be performed economically with acceptable precision, accuracy, and speed.

Contact methods are available for inspecting rod length, diameter, wall thickness, ovality, and camber both before and after loading. Loading methods (particles versus pellets) will have little influence over these inspections. While most of these inspections are performed on the empty tubing, postloading dimensional inspections such as end-cap concentricity and final visual inspection require development of remote techniques.

Gamma ray attenuation has been used 42 to determine the density profile along sphere-pac-loaded fuel rods at ORNL. In those runs a ${ }^{60} \mathrm{Co}$ radioisotope source and $\mathrm{NaI}(\mathrm{T} 1)$ detector were used. Fuel rods loaded with a number of different thorium and uranium oxide fuels were scanned. Fue1 rods loaded with $233 \mathrm{U}$ oxide fuel were inspected in a hot-ce11 environment for the $\left(\mathrm{Th}, 23 \mathrm{U}^{\mathrm{U}} \mathrm{O}_{2}\right.$ Kilorod project at ORNL. 43

A gamma scanning device is under development at ORNL. The device will function as an accurate level-sensing device and can be used to determine the overall length of the packed bed. A weighing fixture will be required to obtain an accurate weight of the packed fuel bed. Alternative methods involving weighing the fuel before dispensing need to be evaluated to determine the smear density measuring method most compatible with the loading technique and with acountability requirements. If fuel weight determination after loading is acceptable, the procèdures may be simplified. In any case, the development needed relates more to remote operational requirements than to peculiarities of particle fuels.

Contact equipment exists for measuring fissile distribution.44-46 However, these methods would be influenced by high radiation levels. For example, if one is concerned with refabricated fuel of high gamma activity or with spiked fuels, then a delayed fission gamma ray method for detecting the distribution of the fissile material along a fuel rod may not be applicable. In such cases, the detection of prompt fission neutrons from the irradiated sample may be used. 47 


\subsubsection{Required Development}

Equipment items that are now being developed on an engineering scale must be tested at prototypic size and evaluated for service in radioactive and remote environments. To this extent equipment used or associated with loaded rods, such as end-plug welders, density scanners, and assay devices, is more advanced because of parallel development in pellet-based fuel refabrication programs. Extensive development will be required for the dispensers, weighers, blenders, and vibrators, which are unique to the sphere-pac concept.

In addition to equipment development, process development is required to determine the optimum particle sizes, blend compositions, and input vibration to achieve high loading density and short loading times.

\subsubsection{Fuel Element Assembly}

\subsubsection{Functional Definition}

The fuel element assembly task begins with the acceptance of inspected fuel rods. These rods are stored in a retrievable surge storage location until they are required for element assembly. Good record keeping and identification methods are required during storage as rods of several enrichments may be stored in the same area. These rods are then fit into an assembly, which is held together by the upper and lower end fittings, spacer grids, and guide tubes. Final assembly welds are automatically made with microprocessor control. Inspection of the finished assembly requires dimensional checks and a pressure drop test through the flow channel. Rework of defective assemblies is also provided. 


\subsubsection{Technology Status}

The work performed in this task is identical to the processing steps required for conventional pellet-based fuel element assembly. Commercial facilities exist where these operations are executed in a contact operation. Various efforts have been and continue to be sponsored to develop remote rod handling and rod and element assembly capability. $48-69$

\subsubsection{Required Development}

Cooperation between fuel element designers and fabricators is needed to develop fully remote assembly procedures. The size and weight of finished assemblies necessitate that handling be done with in-cell cranes. Fabrication specifications require unusually close tolerances for this large finished element. Remotely operable inspection devices must also be developed.

\subsubsection{Scrap Handling}

\subsubsection{Functiona1 Definition}

Three types of scrap are handled by this system. The first is generated by spheres that fail to sinter properly, are of the wrong size, are broken during processing, or are unacceptable for any reason. These particles are collected, assayed, and shipped to the reprocessing plant. All equipment needed for in-plant particle transfer, assay, and off-site shipping are supplied by this task.

The second source of scrap generation is fuel rods that fail to pass product tolerances on column height, fuel density, or axial density uniformity. Such off-specification fuel rods are received by the scrap handling system and opened to remove fuel particles. Equipment to open the rods and to size classify fuel particles and return them to feed storage hoppers of the proper enrichment is required. 
The last classification of scrap is comprised of recoverable plutonium contained in both liquid and solid wastes. In the scrap handing system the plutonium is separated from the remaining waste and returned to the reprocessing facility. This remaining material is transferred to waste processing.

\subsubsection{Technology Status}

While no work has been done to address the first two categories of scrap material, no major technological breakthroughs are required. Adequate systems can be developed with technology borrowed from other areas of the refabrication process.

The third class of scrap handling is not unique to sphere pac. Equipment and process development for plutonium recovery is in its infancy for all fuel forms except HTGR-related engineering analyses. A large quantity of thorium-uranium scrap has been processed at ORNL to

recover the ${ }^{23} 3_{\mathrm{U}}$. The recovery used a batch dissolver designed specifically for scrap, fluoride in nitric acid dissolution, and cleanup by solvent extraction and/or ion exchange. This operation was performed remotely but directly maintained after facility cleanout.

\subsubsection{Required Development}

Operating systems must be demonstrated for each category of scrap handling.

\subsubsection{Waste Processing and Disposal}

\subsubsection{Functional Definition}

In this system waste from the scrap recovery process still containing a small amount of unrecoverable mixed oxide will be processed for permanent disposal. Aqueous wastes will be concentrated and solidified, solids will be compacted, and both types will be assayed before shipping. 


\subsubsection{Technology Status}

Waste from fuel fabrication operations is currently being handled in commercial plants by compaction and packaging of solids and evaporation of liquids. The introduction of the spike will impose added restrictions on these types of activities. Combustible reprocessing waste material in plutonium handling facilities is currently being burned. The ash is assayed and treated for fissionable material recovery or disposed of with other noncombustible solids. Liquids are treated for acid recovery and concentration. The disposition of the sludge from liquid waste will depend on government requirements and regulations now being developed.

\subsubsection{Required Development}

Largely, current ongoing waste treatment development must be adapted to the processing of the relatively small quantities of waste generated in this plant. Initial development will center on the monitoring of ongoing development activities for waste treatment and the identification of waste forms generated together with predicted quantities generated in each category. Subsequent development will involve adaptation of processes developed for these categories to the sphere-pac plant requirements.

\subsection{RESEARCH, DEVELOPMENT, AND DEMONSTRATION RESOURCE REQUIREMENTS ESTIMATES}

Having established the current technology status and development requirements, we preliminarily estimated the resource requirements needed to bring the processes and equipment designs to a level suitable for commercial plant design and construction.

The estimation process involved the development of a summary work schedule in which the individual functional areas were addressed. An estimate was made on a year by year basis of the manpower, equipment, 
and facility requirements for each functional area. The resulting requirements were then reviewed, minor adjustments made to smooth out year-to-year fluctuations, and the resulting requirements summarized.

Table 8.2 presents the resource requirements based upon a functional area distribution. All operational costs including process equipment, maintenance requirements, development of controls, accountability features, etc., have been distributed to the functional areas. Since the facility requirements for the hot engineering tests and the cold prototype tests will cover all functional areas, they are listed separately. With reference to these facility costs, the following considerations apply. The hot engineering estimate is based on modification of the existing Thorium-Uranium Recycle Facility (TURF) at ORNL. The cold prototype is based on the assumed construction of a new facility and includes in its estimate equipment, such as cranes and electromechanical manipulators, that would be required to operate and maintain the process equipment. Process equipment costs for the hot engineering test are included under the special equipment estimates, while similar equipment for the cold prototype test is shown in the major project funds column.

The activities included under program management and design studies include reference process flowsheet development, feasibility studies for the overall process, conceptual design costs, overall program management, and fuel qualification monitoring.

The resource estimates for fuel qualification include test design, monitoring, postirradiation examination costs, and hardware materials costs. They exclude actual test fuel rod fabrication (which is incorporated in the specific functional areas), fissionable materials supplies (which are included in the conversion process $R \& D$ costs shown in the Appendix), and any costs that might be charged for irradiation space.

Table 8.3 shows the estimated funding requirements and manpower needs as a function of project year, excluding the fuel qualification costs. The actual research and development activities are essentially complete with the start of the Title II design for the plant in year 
Table 8.2. Research and Development Resource Requirements Estimates ${ }^{a}$ by Functional Areas

\begin{tabular}{|c|c|c|c|c|c|c|c|}
\hline \multirow{2}{*}{\multicolumn{2}{|c|}{ Functional Area }} & \multirow{2}{*}{$\begin{array}{l}\text { Program } \\
\text { Years } \\
\text { Involved }\end{array}$} & \multirow{2}{*}{$\begin{array}{l}\text { Total } \\
\text { Manpower } \\
\text { Required } \\
\text { (FTE) } b\end{array}$} & \multicolumn{2}{|c|}{ Total Operating Funds } & \multirow{2}{*}{$\begin{array}{l}\text { Major } \\
\text { Project } \\
\text { Funds }\end{array}$} & \multirow{2}{*}{$\begin{array}{c}\text { Total } \\
\text { Cost } \\
\text { Estimates }\end{array}$} \\
\hline & & & & Normal & $\begin{array}{c}\text { Special } \\
\text { Equipment }\end{array}$ & & \\
\hline 1.0 & Receiving and Storage & $1-5$ & 30 & 3.0 & 0.5 & & 3.5 \\
\hline & Fuel Production & $1-8$ & 190 & 20.0 & 3.0 & 7.0 & 30.0 \\
\hline & Fuel Rod Fabrication & $1-8$ & 350 & 35.0 & 4.5 & 15.0 & 54.5 \\
\hline & Element Assembiy & $1-10$ & 240 & 24.0 & 1.0 & 10.0 & 35.0 \\
\hline 5.0 & Scrap Recovery & $1-5$ & 30 & 3.0 & 0.4 & 2.5 & 5.9 \\
\hline 6.0 & Waste Treatment & $1-10$ & 40 & 4.0 & 0.5 & 3.0 & 7.5 \\
\hline 7.0 & Program Management and Design Studies & $1-10$ & 350 & 35.0 & & & 35.0 \\
\hline & Fuel Qualification & $1-16$ & & 20.0 & & & 20.0 \\
\hline \multicolumn{8}{|c|}{ Special Facilities } \\
\hline A. & Hot Tests & $1-5$ & & & & 10.0 & 10.0 \\
\hline \multirow[t]{2}{*}{ B. } & Cold Prototype & $5-9$ & & & & 25.0 & 25.0 \\
\hline & TOTALS & & $\overline{1230}$ & 144.0 & $\overline{9.9}$ & 72.5 & 226.4 \\
\hline
\end{tabular}

${ }^{a} \mathrm{All}$ cost estimates in millions of dollars (constant 1978).

$b_{\text {FTE }}=$ full-time equivalent in person years. 
Table 8.3. Research and Development Resource Requirements Estimates ${ }^{a}$ by Program Year

\begin{tabular}{|c|c|c|c|c|c|c|}
\hline \multirow{2}{*}{$\begin{array}{l}\text { Program } \\
\text { Years }\end{array}$} & \multirow{2}{*}{$\begin{array}{l}\text { Total } \\
\text { Manpower } \\
\text { Required } \\
\text { (FTE) } b\end{array}$} & \multicolumn{2}{|c|}{ Operating Funds } & \multicolumn{2}{|c|}{ Major Project Funds } & \multirow{2}{*}{ Tota1 } \\
\hline & & Normal & $\begin{array}{c}\text { Special } \\
\text { Equipment }\end{array}$ & Equipment & Facilities & \\
\hline 1 & 58 & 5.8 & 0.1 & & 1.2 & 7.1 \\
\hline 2 & 70 & 7.0 & 1.2 & & 1.8 & 10.0 \\
\hline 3 & 81 & 8.4 & 0.2 & & 2.4 & 11.0 \\
\hline 4 & 82 & 8.5 & 1.7 & & 3.0 & 13.2 \\
\hline 5 & 83 & 8.4 & 0.7 & 4.6 & 4.5 & 18.2 \\
\hline 6 & 89 & 9.2 & 0.9 & 6.8 & 4.6 & 21.5 \\
\hline 7 & 110 & 11.2 & 1.2 & 9.1 & 6.1 & 27.6 \\
\hline 8 & 105 & 10.6 & 1.0 & 11.4 & 7.5 & 30.5 \\
\hline 9 & 91 & 9.3 & 0.7 & 5.6 & 3.9 & 19.5 \\
\hline 10 & 85 & 8.3 & 0.5 & & & 8.8 \\
\hline 11 & 80 & 7.9 & 0.8 & & & 8.7 \\
\hline 12 & 70 & 7.0 & 0.3 & & & 7.3 \\
\hline 13 & 59 & 5.5 & 0.3 & & & 5.8 \\
\hline 14 & 56 & 5.4 & 0.1 & & & 5.5 \\
\hline 15 & 55 & 5.8 & 0.1 & & & 5.9 \\
\hline $16^{c}$ & 55 & 5.7 & 0.1 & & & 5.8 \\
\hline TOTALS & 1,230 & 124.0 & 9.9 & 37.5 & 35.0 & $206.4^{d}$ \\
\hline
\end{tabular}

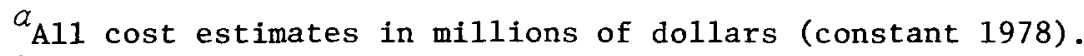

$b_{\text {FTE }}=$ full-time equivalent in person years.

cYear in which demonstration plant begins hot operation.

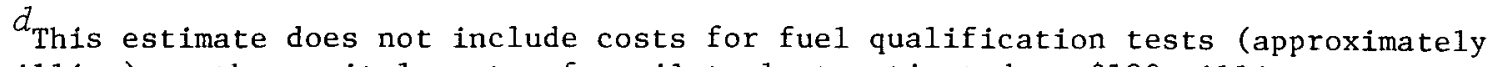
$\$ 20$ million) or the capital costs of a pilot plant estimated at $\$ 190$ million. 
ten. However, the completion of irradiation qualification testing, report writing, and support of early demonstration plant operation has been included through program year 16 to ensure a smooth transition.

Table 8.4 shows anticipated costs associated with the design, construction and first four years of operation of the demonstration plant. The estimates have been made to address two cases. The primary case is a colocated reprocessing and fabrication demonstration plant that uses shared ventilation and waste treatment facilities. The second case is a separate refabrication plant. Such a plant would probably require inclusion of the sphere forming processes to provide its own feed materials. These process additions have been added to this estimate.

Table 8.4. Estimated $\operatorname{Costs}^{\alpha}$ for a Demonstration Plant with Sphere-Pac Fabrication of LWR (U, Pu) $\mathrm{O}_{2}$ Spiked Fuel

\begin{tabular}{|c|c|c|c|c|c|}
\hline \multirow{2}{*}{$\begin{array}{l}\text { Program } \\
\text { Year }\end{array}$} & \multirow{2}{*}{ Event } & \multicolumn{2}{|c|}{$\begin{array}{l}\text { Combined Reprocessing } \\
\text { and Refabrication Plant }\end{array}$} & \multicolumn{2}{|c|}{$\begin{array}{c}\text { Separate } \\
\text { Fabrication Plant }\end{array}$} \\
\hline & & $\begin{array}{l}\text { Design and } \\
\text { Construction }\end{array}$ & Operating & $\begin{array}{l}\text { Design and } \\
\text { Construction }\end{array}$ & Operating \\
\hline 9 & $\begin{array}{l}\text { Start of } \\
\text { Detailed Design }\end{array}$ & 12.5 & 1 & 5.5 & 1 \\
\hline 10 & & 32.5 & 2 & 14.3 & 1 \\
\hline 11 & & 91.0 & 5 & 40.1 & 2 \\
\hline 12 & & 221.0 & 11 & 97.2 & 3 \\
\hline 13 & & 135.5 & 17 & 59.6 & 4 \\
\hline 14 & & 7.5 & 22 & 3.3 & 5 \\
\hline 15 & & & 22 & & 6 \\
\hline 16 & $\begin{array}{l}\text { Start of } \\
\text { Hot Operation }\end{array}$ & & 55 & & 14 \\
\hline 17 & & & 55 & & 14 \\
\hline 18 & & & 55 & & 14 \\
\hline 19 & & & 55 & & 14 \\
\hline & & 500.0 & 300 & 220.0 & 78 \\
\hline
\end{tabular}

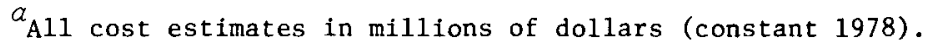




\subsection{REFERENCES}

1. Sol-Gel Processes for Ceramic Nuclear Fuels, International Atomic Energy Agency, Vienna, 1968.

2. Sol-Gel Processes and Reactor Fuel Cycles, CONF-700502 (May 4-7, 1970).

3. A. L. Lotts et a1., Fast Breeder Reactor Oxide Fuels Development Final Report, ORNL-4901 (November 1973).

4. Sol-Gel Processes for Fuel Fabrication, IAEA-161, International Atomic Energy Agency, Vienna, 1974.

5. P. F. Sens et al., "Fabrication of Vibrasol Fuel Rods," Proc. European Nuclear Conf., Paris, France (April 1975), to be published by Pergamon Press.

6. H.W.H. Lahr, "Fabrication, Properties, and Irradiation Behavior of U/Pu Particulate Fuel for Light Water Reactors," Nucl. Technol. 31: 183-90 (November 1976).

7. A. Calza-Bini et al., "Thermal Behavior of Vibrocompacted Sol-Gel Fuel Pin," pp. 247-93 in Sol-Gel Processes for Fuel Fabrication, IAEA-161, International Atomic Energy Agency, Vienna, 1974.

8. R. W. Stratton and L. Smith, "The Irradiation Behavior of Sphere-Pac Carbide Fuel," pp. 349-60 in Advanced LMFBR Fuels, Proceedings of Topical Meeting, Tuscon, Arizona (October 10-13, 1977).

9. W. J. Lackey et al., Assessment of Gel-Sphere-Pac Fuel for Fast Breeder Reactors, ORNL-5468 (October 1978).

10. R. L. Beatty, R. E. Norman, and K. J. Notz, Comps., Gel-Sphere-Pac Fuel for Thermal Reactors - Assessment of Fabrication Technology and Irradiation Performance, ORNL-5469 (in press).

11. M. J. Bannister, "Sintering Mechanisms in Thoria Ge1," J. Am. Ceram. Soc. 58(1-2): 10-14 (1975).

12. H. Suzuki, T. Hase, and T. Iseki, "A New Aspect of Grain Growth of Sol-Gel Urania," J. Nucl. Sci. Technol. 11(4): 146-52 (1974).

13. H. Suzuki et al., "Initial-Stage Sintering of Sol-Gel Urania," $J$. Nucl. Sci. Technol. 11(5): 208-15.(1974).

14. H. Landsperský and Z. Spitzer, "Changes in Pore Structure of Polyuranate Gels in Various Stages of Their Thermal Treatment: Part I - Drying and Calcination," Jad. Energ. 22(2): 59-67 (1976). 
15. H. Landsperský and I. Vaněček, "Thermal Processing of Intermediate Products Prepared by the Sol-Gel Method for the Production of Sintered Uranium Dioxide Spheres," Jad. Energ. 21(1): 11-16 (1975).

16. R. Breschi, A. Camanzi, and A. Olivi, "Changes of Microstructure on Uranium Oxides During the Sintering Process," Energ. Nucl. (Milan) 23(6): 317-22 (1976).

17. H. Landsperský and Z. Spitzer, "Changes in Pore Structure of Polyuranate Gels in Various Stages of Their Thermal Treatment: Part II - Reduction and Sintering," Jad. Energ. 23(5): 169-75 (1977).

18. R. Förthmann et a1., "Investigations on the Preparation of $\mathrm{UO}_{2}$ Microspheres by Internal Gelation of a $\mathrm{UO}_{2}$ Sol and from a Uranium(VI) Solution," pp. 551-66 in Symposium on Sol-Gel Processes and Reactor Fuel Cycles, CONF-700502 (May 1970).

19. A. Facchini and P. Gerontopulos, "Present State of the Art of the SNAM Process for the Preparation of Ceramic Nuclear Fuel Microspheres," pp. 227-45 in Sol-Gel Processes for Fuel Fabrication, IAEA-161, International Atomic Energy Agency, Vienna, 1974.

20. C. J. Hardy, K. R. Hyde, and C. E. Lyon, "Investigations on Porous $\mathrm{UO}_{2}$ Spheres Made by a Sol-Gel Process," pp. 510-20 in Symposium on Sol-Gel Processes and Reactor Fuel Cycles, CONF-700502 (May 1970).

21. R. A. Bradley and T. B. Lindemer, LMFBR Fuel Cycle Studies Prog. Rep. January 1971, ORNL/TM-3312, p. 64.

22. P. A. Haas et al., "Engineering Development of Sol-Gel Processes at the Oak Ridge National Laboratory," pp. 279-318 in I Processi Sol-Gel Per La Produzione Di Combustibili Ceramici Turin (Proc. Int. Nucl. Symp. Oct. 2-3, 1967), Comitato Nazionale Energia Nucleare, Rome, 1968.

23. C. C. Haws and J. W. Snider, A Vertical-Tube Fumace for Continuously Calcining Sol-Gel Derived $\mathrm{ThO}_{2}-\mathrm{UO}_{2}$ at a Rate of 35 Kilograms per Day, ORNL-3894 (January 1969).

24. G. Brambilla et al., "The SNAM Process for the Production of Ceramic Nuclear Fuel Microspheres," pp. 191-209 in Symposium on Sol-Gel Processes and Reactor Fuel Cycles, CONF-700502 (May 1970).

25. A. Facchini, "The SNAM Process for the Preparation of Ceramic Nuclear Fue1 Microspheres: Continuous Production Technique," Energ. Nucl. (Milan) 17(4): 225-33 (1970). 
26. Personal communication, F. de Rooy and F. W. Hamburg, ECN Petten, the Netherlands.

27. H. Huschka, R. Förthmann, and E. Zimmer, "Kernel Fabrication for Different Fuel Cycles in Germany," pp. 37-47 in Sol-Gel Processes for Fuel Fabrication, IAEA-161, International Atomic Energy Agency, Vienna, 1974.

28. J. E. Mack and W. H. Pechin, Automatic Particle-Size Analysis of HTGR Recycle Fuel, ORNL/TM-5907 (September 1977).

29. W. J. Lackey, D. P. Stinton, L. E. Davis, and R. L. Beatty, "Crushing Strength of High-Temperature Gas-Cooled Reactor Fue1 Particles," Nucl. Technol. 31(2): 191-201 (November 1976).

30. W. J. Lackey and R. A. Bradley, "Microstructure of So1-Ge1-Derived (U, Pu) $\mathrm{O}_{2}$ Microspheres and Pellets," Nucl. Technol. 14: 257-68 (1972).

31. C. J. Hardy et al., "Examination of Sol-Gel UO 2 Surfaces by Scanning Electron Microscopy," pp. 61-69 in Sol-Gel Processes for Ceramic Nuclear Fuels, International Atomic Energy Agency, Vienna, 1968.

32. J. J. Hauth, Vibrationally Compacted Ceramic Fuels, HW-6777 (January 1961).

33. J. J. Hauth, "Vibrational Compaction of Nuclear Fuels," pp. 253-76 in Perspectives in Powder Metallurgy; Volume 2, Vibratory Compacting, Ed. by H. H. Hausner, Plenum Press, New York,

34. P. E. Evans and R. S. Millman, "The Vibratory Packing of Powders," pp. 237-51 in Perspectives in Powder Metallurgy; Vol. 2, Vibratory Compacting, Ed. by H. H. Hausner, Plenum Press, New York, 1967.

35. R. R. Suchomel, A. J. Caputo, and W. J. Lackey, "Sphere-Pac - A Practical Remote Fuel Fabrication Concept," (Summary) Trans. Am. Nucl. Soc. 32 (TANSAO 32): 276 (June 1979).

36. J. E. Mack and D. R. Johnson, Development of a Pneumatic Transfer System for HTGR Recycle Fuel Particles, ORNL/TM-6169 (February 1978).

37. R. R. Suchomel and W. J. Lackey, Device for Sampling HTGR Recycle Fuel Particles, ORNL/TM-5739 (March 1977).

38. A. R. 01sen, S. A. Rabin, J. W. Snider, W. S. Ernst, and J. W. Tackett, Fabrication and Preirradiation Information on Vibratorily Compacted $\mathrm{ThO}_{2}-\mathrm{UO}_{2}$ Fuel Rods for Experiments ETR-I and MTR-III, ORNL/TM-1322 (January 1966). 
39. W. H. Pechin, R. A. Bradley, W. J. Lackey, and J. D. Sease, "Analysis of $(\mathrm{U}, \mathrm{Pu})_{2}$ Fuels at Oak Ridge National Laboratory," pp. 279-94 in Analytical Methods in the Nuclear Fuel Cycle, International Atomic Energy Agency, Vienna, 1972.

40. F. G. Kitts, R. B. Fitts, and A. R. Olsen, "Sol-Gel Urania-Plutonia Microsphere Preparation and Fabrication Into Fuel Rods," pp. 195-210 in. Int. Symp. Plutonium Fuels Technol., Scottsdale, Ariz., 1967, Nucl. Met. 13, Ed. by K. E. Horton, R. E. Macherey, and R. J. Allio, American Institute of Mining, Metallurgical, and Petroleum Engineers, New York, 1968.

41. A. R. 01sen, "ETR Tests - Noninstrumented Series," Fast Breeder Reactor Oxide Fuels Development - Final Report, ORNL-4901 (November 1973), pp. 58-72.

42. B. E. Foster and S. D. Snyder, "Evaluation of Variables in the Measurement of Fuel Concentration Variations in Nuclear Fuel Rods," Mater. Eval. 26(2): 27-32 (1968).

43. J. D. Sease, A. L. Lotts, and F. C. Davis, Thorium-Uranium-233 Oxide (Kilorod) Facility - Rod Fabrication Process and Equipment, oRNL-3539 (1964).

44. R. N. Kubik and W. G. Pettus, "Experience with a Fuel Rod Enrichment Scanner," Nucl. Mater. Manage. 4(3): 194-201 (Fa11 1975).

45. C. P. Ruiz, A. C. Duckart, and J. E. Menick, "Nuclear Fuel Rod Active Gamma Scan System, Trans. Am. Nucl. Soc. 16: 89-90 (June 1973).

46. P. Goris and A. W. DeMerschman, FFTF Fuel Pin Nondestmuctive Assay Measurements, HEDL-SA-950 (October 1975).

47. J. D. Jenkins, S. R. McNeany, and J. E. Rushton, ConceptuaZ Design of the Special Nuclear Material Nondestructive Assay and Accountability System for the HTGR Fuel Refabrication Pilot Plant, ORNL/TM-4917 (July 1975).

48. M. J. Swanson et al., "Preliminary Design of the Hot Fuel Examination Facility (HFEF)," p. 131 in Proc. 17th Conf. Remote Systems Technology, American Nuclear Society, Hinsdale, Illinois (1969).

49. T. W. Eckels and D. Mingesz, "Gastight Shielding Window Design for the Hot Fuel Examination Facility," p. 192 in Proc. 17th Conf. Remote Systems Technology, American Nuclear Society, Hinsdale, Illinois (1969). 
50. E. W. Landow and P. R. Hirsch, "Design of the Hot Fuel Examination System Argon System," p. 196 in Proc. 17th Conf. Remote Systems Technology, American Nuclear Society, Hinsdale, Illinois (1969).

51. N. J. Swanson et a1., "Startup Configuration of the Hot Fuel Examination Facility," p. 109 in Proc. 23rd Conf. Remote Systems Technology, American Nuclear Society, Hinsdale, Illinois (1975).

52. D. A. Tobias and C. A. Frickey, "Techniques for Remote Maintenance of In-Ce11 Material Handling System in the HFEF/N Main Al1," p. 127 in Proc. 23rd Conf. Remote Systems Technology, American Nuclear Society, Hinsdale, Illinois (1975).

53. D. S. Taylor et a1., "Unique Method of Transferring Highly Irradiated Components from an Alpha-Gamma Facility," p. 138 in Proc. 23 rd Conf. Remote Systems Technology, American Nuclear Society, Hinsdale, Illinois (1975).

54. D. B. Hagmann, "Handling System for Large Sodium Loops at Hot Fuel Examination Facility," p. 144 in Proc. 23rd Conf. Remote Systems Technology, American Nuclear Society, Hinsdale, Illinois (1975).

55. J. McClurkin and D. Tobias, "A Pneumatic Transfer System for Inert Atmosphere Hot Cells," p. 161 in Proc. 23rd Conf. Remote Systems Technology, American Nuclear Society, Hinsdale, Illinois (1975).

56. N. J. Swanson and P. R. Hirsch, "Storage of Irradiated EBR-II Subassemblies in an Inert Atmosphere," p. 166 in Proc. 23rd Conf. Remote Systems Technology, American Nuclear Society, Hinsdale, Illinois (1975).

57. N. J. Swanson and R. Kifer, "HFEF/N In-All Motorized Transfer Cart," Proc. 23rd Conf. Remote Systems Technology, American Nuclear Society, Hinsdale, Illinois (1975).

58. D. A. McKenzie and D. Taylor, "Remote Examination, Disassembly, and Reassembly of Grid-Type Reactor Subassemblies at HFEF," p. 181 in Proc. 23rd Conf. Remote Systems Technology, American Nuclear Society, Hinsdale, Illinois (1975).

59. J. R. White et a1., "Handling of Irradiated Elements and Capsules in HFEF/N," p. 201 in Proc. 23rd Conf. Remote Systems Technology, American Nuclear Society, Hinsdale, Illinois (1975). 
60. G. C. McClellan and G. Iverson, "Visual Examination Machine for HFEF/N," p. 211 in Proc. 23rd Conf. Remote Systems Technology, American Nuclear Society, Hinsdale, Illinois (1975).

61. F. J. Just et a1., "Data Acquisition and Process Control System for HFEF," p. 219 in Proc. 23rd Conf. Remote Systems Technology, American Nuclear Society, Hinsdale, Illinois (1975).

62. P. Monnet and J. Robert, "Miniature Radiation Resistant Television Camera," p. 445 in Proc. 23rd Conf. Remote Systems Technology, American Nuclear Society, Hinsdale, Illinois (1975).

63. L. G. Faust and L. W. Brackenbush, "High Exposure P1utonium Fuels from Light-Water Reactors," p. 59 in. Proc. 22nd Conf. Remote Systems Technology, American Nuclear Society, Hinsdale, Illinois (1974).

64. R. A. Williams and E. Crosby, "External Radiation Exposure and Radiotoxicity Considerations in Plutonium/Uranium Mixed Oxide Fuel Fabrication," p. 66 in Proc. 22nd Conf. Remote Systems Technology, American Nuclear Society, Hinsdale, Illinois (1974).

65. R. E. Mullen et al., "Fast Flux Test Facility Core Component Measuring System," p. 67 in Proc. 25th Conf. Remote Systems Technology, American Nuclear Society, Hinsdale, Illinois (1977).

66. R. E. Mullen et al., "Fast Flux Test Facility Element Measuring System," p. 78 in Proc. 25th Conf. Remote Systems Technology, American Nuclear Society, Hinsdale, Illinois (1977).

67. D. R. Doman et al., "Design Features and Objectives of the Fuels and Materials Examination Facility," p. 90 in Proc. 25th Conf. Remote Systems Technology, American Nuclear Society, Hinsdale, Illinois (1977).

68. A. L. Trego et al., "Design and Development of the Examination Equipment for the Fuels and Materials Examination Facility," p. 103 in Proc. 25th Conf. Remote Systems Technology, American Nuclear Society, Hinsdale, Illinois (1977).

69. M. J. Feldman, "A Perspective on the EBR-II Remote Fabrication Experience," Trans. Am. Nucl. Soc. 32 (TANSAO 32): 225-26 (June 1979). 
. .

• 


\section{COMMERCIAL AND TECHNICAL FEASIBILITY \\ OF VARIOUS REACTOR FUEL CYCLES}

The previous sections examined the generic technical feasibility of the ge1-sphere-pac process for fabricating metal-clad fuel elements and its specific application to one type of reactor fuel. During the past two years a number of reactor-fuel combinations have been evaluated in the United States. The specific reactor-fuel combinations and their associated cycles we chose to assess have been an outgrowth of the ongoing NASAP work to identify cycles with a high degree of proliferation resistance. Adequate information was available on fuel element designs and fuel cycle descriptions for five Light-Water Reactor (LWR) cases, one Heavy-Water Reactor (HWR) case, one Gas-Cooled Fast Reactor (GCFR) case and seven Liquid-Metal Fast Breeder (LMFBR) reactor cases. Although some information was available for a number of Light-Water Breeder Reactor (LWBR) cases, the fuel element design data were not adequate for an equivalent commercial fuel fabrication applications analysis but we retained them to show potential application of the gel-sphere-pac fabrication option.

In the following subsections we have assessed the potential commercial applicability of the gel-sphere-pac fabrication process to specific cases. Each case assessment contains the following:

1. description of the fuel cycle;

2. an assessment of the applicability of the gel-sphere-pac process to the fabrication of the fuel;

3. definition of commercial-scale plant production requirements and design capacity;

4. an analysis of functional technology status, research and development requirements, cost and schedule; and

5. a cost estimate for construction and operation of such a commercialscale facility. 
In providing the commercial-scale cost estimates for each case we have followed to the extent possible the estimation procedures that were developed for fabrication plants for the AFCEP and NASAP programs.1-3 These procedures and the resulting cost estimates have been subjected to peer review. The procedures provide a consistent set of estimates wherein the relative costs from cycle to cycle are probably more accurate than the absolute values of the costs for each cycle. In general the cost estimates are, however, considered to be within $\pm 25 \%$ of the actual costs for design, construction, and operation. Anticipated fabrication costs to the reactor operator are given for three different sets of economic factor assumptions.

Since the ge1-sphere-pac processing equipment is at a somewhat earlier stage of development than comparable pellet processing equipment, we have included an additional contingency in these estimates. The average contingency for the ge1-sphere-pac estimates is approximate1y $45 \%$, with a range from 40 to $60 \%$, while comparable pellet estimates have a $30 \%$ contingency.

The research and development cost breakdown has been modified in these abbreviated assessments from that presented in Sect. 8.

In the following subsections the reader will note a high degree of repetition in the narrative. This is intentional for two reasons. First, we intend to make each case assessment an independent section, which does not require constant reference to other cases in the report. Second, the repetition permits a ready comparison of cases and identification of the differences. Fuel fabrication cost estimates are of necessity specific for a particular fuel element design and cycle definition. What appear to be minor modifications in such things as fuel column length, cladding dimensions, or element assembly details can have a significant and not always obvious influence on the cost estimates. The information presented here should be extrapolated to other cases only with a detailed analysis of all features. 
In assessing the applicability of the sphere-pac process to the specific cases in the following sections, the following general considerations were used.

The sphere-pac process is generally applicable to any fuel construction for which conventional pellet forms are suitable. Requirements to be considered in the selection of spheres for a specific application include fuel smear density and cladding dimensions. Fuel smear density can be adjusted and controlled by proper selection of sphere diameters and blend composition. The diameter of the largest spheres, the coarse particles, is governed by production limitations for sphere forming and also by the inside diameter (ID) of the cladding. The ratio of cladding ID to coarse sphere diameter should be greater than 10 for higher densities but must be at least 4 for practical loading densities. As indicated previously, the current gel-sphere forming processes have a practical coarse size diameter limit of between 1200 and $1400 \mu \mathrm{m}$. In addition, the smallest particles, the fines, should be no less than $20 \mu \mathrm{m}$ for forming process practicality and to prevent agglomeration and dusting in handling and loading.

Previous experimental work ${ }^{4}$ using the bed infiltration technique showed that maximum bed packing fraction can be achieved when the ratios between cladding ID and the successive sizes are large, a factor of 20 or more. Bed packing fraction is the portion of available volume within the cladding occupied by the spheres. Theoretically, this could provide smear densities, with $100 \%$-dense particles, approaching $95 \%$ of theoretica 1 density. However, because sphere forming limits diameters to the range 20 to $1400 \mu \mathrm{m}$, the maximum particle-to-particle diameter ratios for a three-particle system is restricted to approximately 8. If the cladding ID is unrestricted, the peak bed packing fraction for a ratio of 8 would be approximately 0.91 .

Introduction of the cladding ID restriction associated with typical fuel elements places further restrictions on the bed packing fraction by further restraint of the particle-to-particle diameter ratios. Thus for 
the range of cladding inner diameters considered here, $12,270 \mu \mathrm{m}$ (HWR) to $6760 \mu \mathrm{m}$ (LMFBR), the maximum bed packing fraction is restricted to approximately 0.89 . This bed packing combined with the practical sphere densities of $99 \%$ of theoretical yields a practical smear density approximately $88 \%$ of theoretical.

The current work on simultaneous loading of all three size fractions is determining the practical limits for various sizes of cladding. To date densities of 83 to $88 \%$ have been achieved, depending on cladding ID. 
9.1 NASAP CASE $1.2-$ PWR- $\left(235_{U}, \mathrm{U}\right) \mathrm{O}_{2}$ EXTENDED BURNUP [PWR LEU(5) - MOD OT]

\subsubsection{Fuel Cycle Description}

This reactor fuel cycle combination is a PWR using 4.3\%-enriched uranium oxide pellet fuel, modified to achieve $50 \mathrm{MWd} / \mathrm{kg}$ average burnup and other means to decrease uranium requirements, operating on a oncethrough cycle. Spent fuel will be stored at the reactor site or at another storage facility. Ultimately, the spent fuel will be sent to a geologic spent fuel repository.

In this fuel cycle only fresh fuel is fabricated in a contactoperated and contact-maintained ( $\mathrm{CO} / \mathrm{CM})$ plant. Existing industrial plants could logically fabricate these fuel elements by the pelletizing process. The applicability of the gel-sphere-pac process was assessed because the fuel it produces shows a potential performance advantage in the reactor. A small body of experimental data indicates that fuel-cladding mechanical and chemical interactions are less for sphere-pac fuel than for pelletized fuel with the same smear density within the rod.4,5

\subsubsection{Applicability to Current Fuel Element Design}

There are a number of existing pressurized-water reactor fuel element designs, and all of them are similar in their requirements for fuel rod loading. For this analysis, the representative design chosen for case 1.2 is presented in Table 9.1.

The key considerations for sphere-pac applicability are the cladding inside diameter measurements and the required fuel smear density. The cladding ID of $8433 \mu \mathrm{m}$ in the reference design is suitable for the spherepac process. In addition, since the design smear density of $88 \%$ is essentially that achieved with experimental blended (three particle size) sphere-pac beds, the process is applicable. 
Table 9.1. Summary of C-E System 80 PWR $16 \times 16$ Fuel Assemb1y Parameters [NASAP Case $1.2-\mathrm{PWR}-\left({ }^{235} \mathrm{U}, \mathrm{U}\right) \mathrm{O}_{2}$ Extended Burnup]

\section{Reactor Characteristics}

$\begin{array}{ll}\text { Reactor power } & 1300 \mathrm{MWe} \text { (net) } \\ \text { Fuel assemblies/core } & 241 \\ \text { Reload cycle } & \text { Annual ( } 1 / 3 \text { per reload) }\end{array}$

\begin{tabular}{|c|c|c|c|}
\hline Component Characteristics & Materials & $\begin{array}{c}\text { Number per } \\
\text { Fuel Assembly }\end{array}$ & $\begin{array}{l}\text { Mass per Fuel } \\
\text { Assembly, kg }\end{array}$ \\
\hline Cladding & Zircaloy -4 & 236 & 113.47 \\
\hline \multicolumn{4}{|l|}{ End plugs } \\
\hline Top & Zircaloy-4 & 236 & 0.80 \\
\hline Bottom & Zircaloy-4 & 236 & 1.04 \\
\hline Plenum springs & 302 SS & 236 & 7.33 \\
\hline \multicolumn{4}{|l|}{ Guide tubes } \\
\hline Instrument & Zircaloy -4 & 1 & 2.10 \\
\hline Control element & Zircaloy -4 & 4 & 8.85 \\
\hline \multicolumn{4}{|l|}{ Spacer grids } \\
\hline Top & Zircaloy -4 & 1 & 0.82 \\
\hline Middle & Zircaloy -4 & 10 & 8.62 \\
\hline Bottom & A11oy 625 & 1 & 1.00 \\
\hline \multicolumn{4}{|l|}{ End fittings } \\
\hline Top & $\begin{array}{l}304 \text { SS with alloy } \\
\text { X-750 hold-down } \\
\text { springs }\end{array}$ & 1 & 18.60 \\
\hline Bottom & $\mathrm{CF}-8 \mathrm{SS}$ & 1 & 5.63 \\
\hline Insulator pellets & $\mathrm{Al}_{2} \mathrm{O}_{3}$ & 472 & 1.18 \\
\hline
\end{tabular}

Fuel Rod Characteristics

Cladding outside diameter $9.70 \mathrm{~mm}$ ( 0.382 in.)

Cladding inside diameter $8.43 \mathrm{~mm}$ (0.332 in.)

Fuel rod length $4.11 \mathrm{~m}$ (162 in.)

Fuel column height $\quad 3.81 \mathrm{~m}$ (150 in.)

Fuel smear density $\quad 88 \%$ T.D.

Pellet diameter $\quad 8.26 \mathrm{~mm}(0.325 \mathrm{in.})$

Pellet length $\quad 9.91 \mathrm{~mm}$ (0.390 in.)

Fuel Assembly Characteristics

$\begin{array}{ll}\text { Array } & 16 \times 16 \text { square } \\ \begin{array}{l}\text { Dimensions } \\ \quad \text { Width }\end{array} & 203 \mathrm{~mm}(7.98 \mathrm{in.}) \\ \quad \text { Length } & 4.49 \mathrm{~m}(177 \mathrm{in.}) \\ \text { Mass of structural } & 169.73 \mathrm{~kg} \\ \quad \text { components } & \\ \text { Heavy metal content } & 427 \mathrm{~kg}\end{array}$




\subsubsection{Definition of Plant Production Requirements and Design Capacity}

For the PWR $\left({ }^{\left.235_{U}, U\right) 0_{2}}\right.$ fuel cycle, the plant design assumptions are as follows.

1. The fuel design is the Combustion Engineering System $8016 \times 16$ rod array fuel assembly.

2. The plant production capacity is $520 \mathrm{t} \mathrm{HM} /$ year with the capability for simultaneous production of three enrichments.

3. The plant factor is 260 effective ful1-production days per year.

4. P1ant design capacity:

Overall

Each line of three
$730 \mathrm{t} \mathrm{HM} /$ year

about 5 fuel assemblies/d

$243 \mathrm{t} \mathrm{HM} /$ year

$0.67 \mathrm{tHM} / \mathrm{d}$

369 fuel rods/d

1.6 fuel assemblies/d

5. Process design capacities are based on the line design capacities and the scrap and sample losses defined in Sect. 9.1.4.

6. The facilities are designed to discharge no liquid waste other than treated sanitary sewage.

7. All process buildings and critical auxiliary support are designed and constructed in accordance with current United States Nuclear Regulatory Commission licensing requirements. Shielding is provided to limit dose rates to operating and maintenance personnel to $0.25 \mathrm{millirem} / \mathrm{h}$.

\subsubsection{Estimates of Surge Storage Requirements, Scrap Production Rates, and Processing Rates for Functional Steps}

Given the plant design assumptions defined in Sect.9.1.3, further commercial plant characteristics were derived.

To achieve the annual production rates, an analysis of the plant surge storage requirements and normal inventory was made, and the results of this analysis are given in Table 9.2.

Based on current technology and assuming reasonable extrapolations for commercial-scale developments, a preliminary estimate was made of the 
Table 9.2. Sphere-Pac Fabrication Plant Surge Storage Requirements and Normal Inventory [NASAP Case 1.2 PWR LEU(5) - MOD OT]

\begin{tabular}{|c|c|c|c|c|c|}
\hline \multirow{2}{*}{ Process Step } & \multirow{2}{*}{ Material } & \multicolumn{2}{|c|}{$\begin{array}{l}\text { Storage } \\
\text { Interval, } \mathrm{d}\end{array}$} & \multicolumn{2}{|c|}{ Normal Inventory, $\mathrm{kg} H M$} \\
\hline & & Norma 1 & Maximum & $(235 \mathrm{U}, \mathrm{U}) \mathrm{O}_{2} \sigma$ & $\left({ }^{235} \mathrm{U}, \mathrm{U}\right) \mathrm{O}_{2}$ Fines ${ }^{a}$ \\
\hline Feed storage & $\begin{array}{l}\text { Dried spheres } \\
\text { Sintered spheres }\end{array}$ & $\begin{array}{l}30 \\
30\end{array}$ & $\begin{array}{l}60 \\
60\end{array}$ & 50,000 & 13,000 \\
\hline Interim storage & $\begin{array}{l}\text { Dried spheres } \\
\text { Sintered spheres }\end{array}$ & $\begin{array}{l}1 \\
1\end{array}$ & $\begin{array}{l}2 \\
2\end{array}$ & 1,660 & 440 \\
\hline Furnace & $\begin{array}{l}\text { Dried to sintered } \\
\text { spheres }\end{array}$ & 1.2 & 2.4 & 2,000 & \\
\hline Post furnace & Sintered spheres & 0.5 & 1 & 830 & \\
\hline Interim storage & Sintered spheres & 0.36 & 0.72 & 600 & \\
\hline Main storage & $\begin{array}{l}\text { Sintered spheres } \\
\text { Sintered spheres }\end{array}$ & $\begin{array}{l}1.2 \\
1.5\end{array}$ & $\begin{array}{l}2.4 \\
2.9\end{array}$ & 2,100 & 660 \\
\hline $\begin{array}{l}\text { Loading, inspection } \\
\text { welding }\end{array}$ & Sintered spheres & 0.12 & 0.24 & 210 & 50 \\
\hline $\begin{array}{l}\text { Loaded, not inspected } \\
\text { rods }\end{array}$ & $\begin{array}{l}\text { Sintered spheres } \\
\text { in rods }\end{array}$ & 5 & 5 & 8,300 & 2,070 \\
\hline Rework and scrap & Sintered spheres & 2 & 5 & 410 & 75 \\
\hline Completed fuel rods & $\begin{array}{l}\text { Sintered spheres } \\
\text { in rods }\end{array}$ & 5 & 5 & 8,000 & 2,000 \\
\hline Assembly & $\begin{array}{l}\text { Rods in completed } \\
\text { assemblies }\end{array}$ & 15 & 30 & 24,000 & 6,000 \\
\hline
\end{tabular}

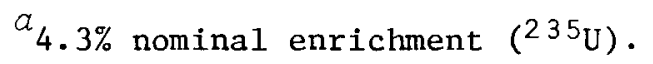


daily mass flows of heavy metal through the fabrication plant and the average production rate of heavy metal scrap materials from the various functional activities. These are presented in Table 9.3.

Given the above information, a preliminary evaluation of the processing rates for each functional step within the main fuel fabrication processes was made. The results of this analysis are summarized in Table 9.4.

9.1.5 Analysis of Functional Technology Status, Research and Development Requirements, Cost, and Schedule

The current functional technology status for this fuel system is essentially identical to the reference case discussed in Sect. 8 of this report. However, the research and development requirements for a $\mathrm{CO} / \mathrm{CM}$ plant, while similar in kind, would be considerably reduced, as shown in Table 9.5, which summarizes the technology status and the current cost estimates.

The major difference in the needed development is the fact that this fuel can be manufactured in a contact plant. Consequent1y, no hot engineering tests or demonstration plant would be needed. Automation of the process would be required for good commercial application so that the cold prototype tests would be required up through fuel rod inspection. No development is needed for fuel element assembly since current commercial practice should be applicable. It will be necessary to develop appropriate scrap recovery processes, but waste treatment would be similar to current commercial practice.

The overall schedule for this development would be controlled by two factors: first, the rate at which the processes for sphere production could be develuped, and second, the time needed to build test elements and provide the necessary qualification for licensing such fuel for commercial reactors. A preliminary estimate indicates that these features could be achieved in 8 to 12 years. 
Table 9.3. Heavy Metal Mass Flows and Average Scrap Production for a Sphere-Pac Fuel Fabrication Plant [NASAP Case 1.2 PWR LEU(5) - MOD OT]

\begin{tabular}{|c|c|c|c|c|c|c|}
\hline \multirow{3}{*}{ Processing Step } & \multicolumn{6}{|c|}{ Mass Flow, kg HM/d } \\
\hline & \multicolumn{2}{|c|}{ Daily Throughput } & \multicolumn{2}{|c|}{ Clean Scrap $b$} & \multicolumn{2}{|c|}{ Reject Scrap ${ }^{c}$} \\
\hline & $(235 \mathrm{U}, \mathrm{U}) \mathrm{O}_{2} a$ & $(235 \mathrm{U}, \mathrm{U}) \mathrm{O}_{2}$ Fines $a$ & $\left({ }^{235} \mathrm{U}, \mathrm{U}\right) \mathrm{O}_{2} a$ & $\left({ }^{235} \mathrm{U}, \mathrm{U}\right) \mathrm{O}_{2}$ Fines ${ }^{a}$ & $\left({ }^{235} \mathrm{U}, \mathrm{U}\right) \mathrm{O}_{2} a$ & $\left({ }^{235} \mathrm{U}, \mathrm{U}\right) \mathrm{O}_{2}$ Fines ${ }^{a}$ \\
\hline Receiving and storage & 1662.3 & $437.8^{d}$ & & & & \\
\hline Sampling and batch loading & 1660.6 & & & & 1.7 & \\
\hline Weighing and sampling & & 437.4 & & & & 0.4 \\
\hline Calcining and sintering & 1659.8 & & & & 0.8 & \\
\hline Sphere upgrading & $1753.1^{e}$ & & & & 49.8 & \\
\hline Sphere sampling & 1749.6 & & & & 3.5 & \\
\hline Sphere storage & 1749.6 & 437.4 & & & & \\
\hline Fuel rod loading & 1749.6 & 437.4 & & & & \\
\hline Fuel rod scanning & 1662.1 & 415.5 & 84.0 & 21.0 & 3.5 & 0.9 \\
\hline Top component insertion & 1658.4 & 414.6 & 3.3 & 0.8 & 0.3 & 0.1 \\
\hline Rod welding and $x$ ray & 1658.4 & 414.6 & $f$ & $f$ & $f$ & $f$ \\
\hline Leak detection & 1658.4 & 414.6 & $f$ & $f$ & $f$ & $f$ \\
\hline Rod assay & 1625.3 & 406.3 & 31.5 & 7.9 & 1.7 & 0.4 \\
\hline Final rod inspection & 1608.4 & 402.1 & 16.3 & 4.1 & 0.7 & 0.2 \\
\hline Assembly inspection & 1600 & 400 & 8.0 & 2.0 & 0.3 & $\underline{0.1}$ \\
\hline Total & 20 & & 143.1 & 35.8 & 62.3 & 2.1 \\
\hline
\end{tabular}

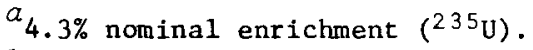

$b_{\text {Internally recycled. }}$

${ }^{c}$ Collected, assayed, and externally recycled to reprocessing plant.

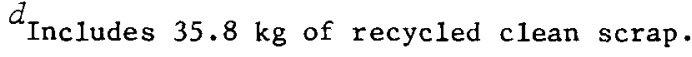

${ }^{e}$ Includes $143.1 \mathrm{~kg}$ of recycled clean scrap.

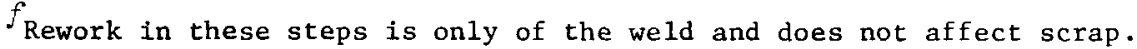


Table 9.4. Equipment Requirements for Functional Areas [NASAP Case 1.2 PWR LEU(5) - MOD OT]

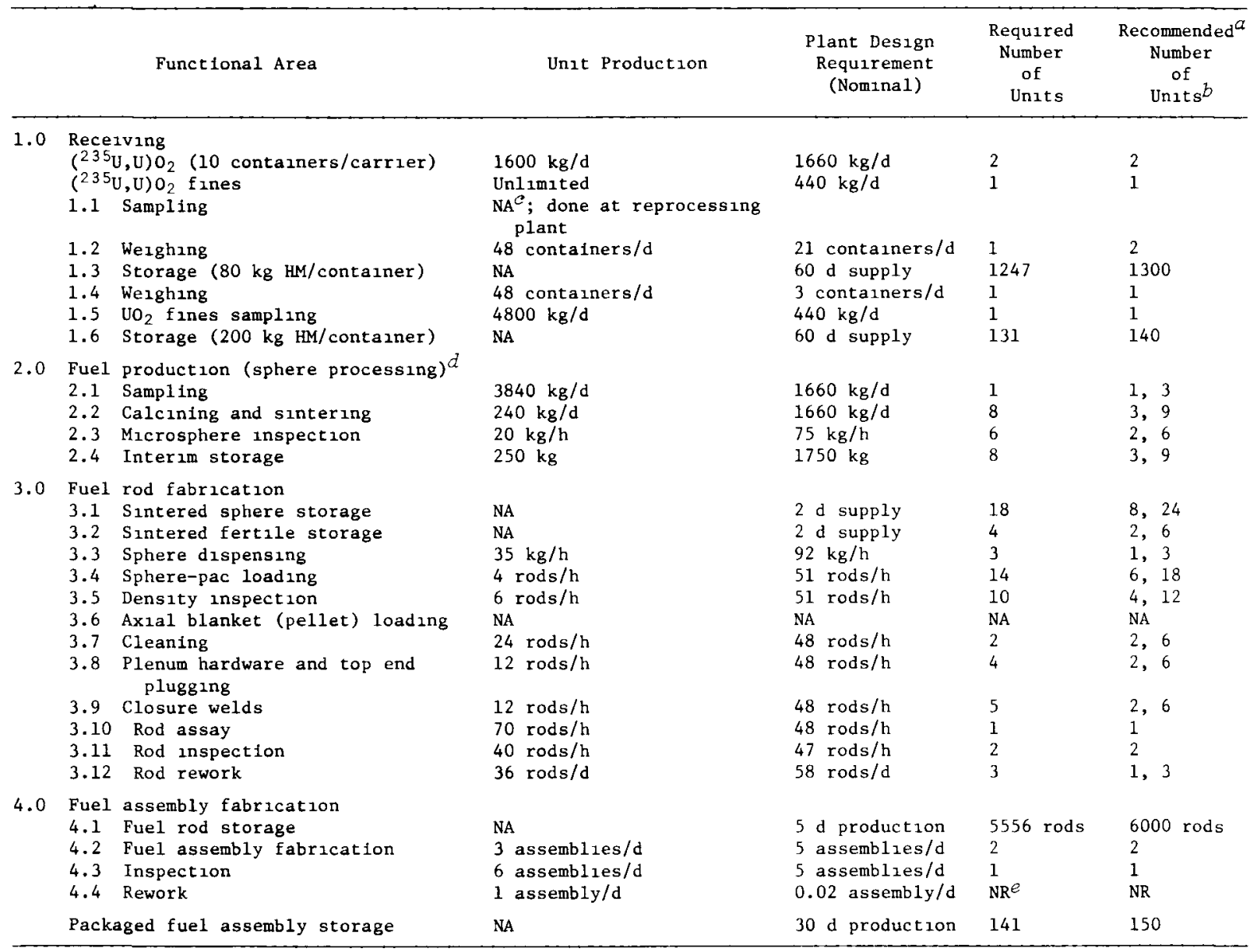

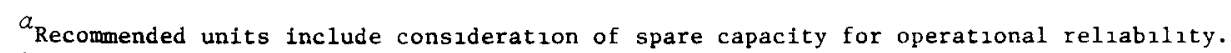

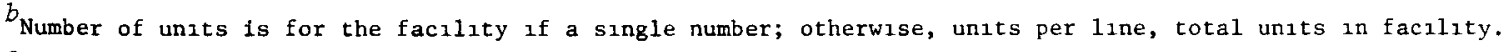
$c_{\text {NA: }}$ not applicable.

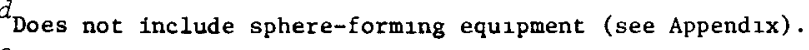

$e_{\mathrm{NR}}$ : not required. Use assembly equipment as avallable. 
Table 9.5. Research and Development Cost Estimates for Sphere-Pac Fabrication [NASAP Case 1.2 PWR LEU(5) - MOD OT]

\begin{tabular}{|c|c|c|c|c|}
\hline & R\&D Categories & Current Status ${ }^{a}$ & $\begin{array}{c}\text { R\&D Cost Estimates } \\
\text { (Millions of } \\
1978 \$ \text { ) }\end{array}$ & $\begin{array}{l}\text { Years to } \\
\text { Complete }\end{array}$ \\
\hline 1.0 & Program management & Not applicable & 5 & 5 \\
\hline 2.0 & Design studies & P - cold prototype & 5 & 5 \\
\hline 3.0 & Receiving and storage & $P-\operatorname{cold}$ engineering & 0 & \\
\hline 4.0 & Fuel production & $P-\operatorname{cold}$ engineering & 19 & 6 \\
\hline 5.0 & Fuel rod fabrication & $P-$ cold engineering & 28 & 6 \\
\hline 6.0 & Fuel element assembly & C - commercial & 0 & \\
\hline 7.0 & Scrap recovery & $C-$ commercial & 0 & \\
\hline 8.0 & Waste treatment & $b$ & $b$ & $b$ \\
\hline 9.0 & Plant control systems & $N-$ cold prototype & 5 & 5 \\
\hline 10.0 & Maintenance & $N$ - cold prototype & 1 & 2 \\
\hline 11.0 & $\begin{array}{l}\text { Safeguards and account- } \\
\text { ability adaptation }\end{array}$ & $P-\operatorname{cold}$ engineering & 4 & 2 \\
\hline & Subtota1 & & 67 & \\
\hline
\end{tabular}

\section{Special Facilities}

Hot tests

Cold prototype

Total

Range
Not required

10

$77^{d}$

70-90

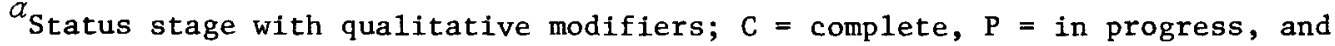
$\mathrm{N}=$ needed.

$b_{\text {To be supplied by others. }}$

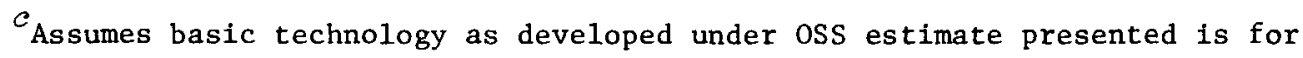
applications testing, systems integraton, and testing.

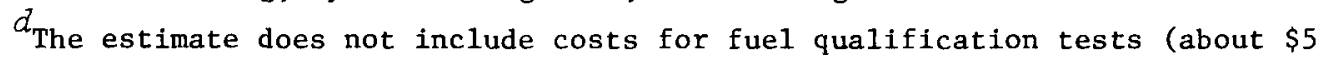
million). 


\subsubsection{Preliminary Cost Estimate for Construction and Operation of a Commercial-Scale Plant}

The cost components that were estimated include capital costs for the facility and equipment, fuel assembly hardware costs, material and supply costs, and operating costs. ${ }^{1-3}$ These cost estimates include the $\mathrm{UO}_{2}$ sphere-forming operations. These operations require an addition to the plant beyond that shown in the reference case to receive $\mathrm{UF}_{6}$ and process it to dried spheres. This has been included in the cost estimate. Facility capital cost estimates were based on an analysis of the functional flow diagram for the process to indicate space requirements for each functional area and for each support area. Equipment requirements were identified, and costs associated with the equipment were estimated. Fuel assemb1y hardware requirements were based on the reference fuel assembly design parameters identified in Table 9.1. Estimates of the costs of the hardware items were obtained. Material and supply requirements were identified from the sphere-pac process description, and estimates of the costs of materials and supplies were obtained. Operating cost estimates included consideration of personnel, overhead, general and administrative expenses, and costs of utilities.

The facility was assumed to operate as a toll processing facility. That is, the operator fabricates customer-supplied fuel feed materials into finished fuel assemblies, and thus costs of uranium were not included in the cost estimates.

Unit costs for fabrication of fue 1 assemblies are determined by an economic analysis of the basic capital, hardware and material, and operating cost estimates. Basically, the economic analysis provides for the owner of the fuel fabrication facility to recover all capital, operating, and finance charges plus a return on investment, if appropriate, over the life of the plant.

In order to provide a range of prices (i.e., costs to a customer), economic analyses were based on government financing, financing appropriate for a conventional-risk (typical) industry, and financing appropriate for a high-risk industry. 2 The estimated costs, costs derived from the economic analysis, and the unit costs based on the three 
different financing methods are summarized in Table 9.6. As may be observed from the table, the price for fabrication of $(235 \mathrm{U}, \mathrm{U}) \mathrm{O}_{2}$ fuel is expected to be in the range from $\$ 100$ to $\$ 150 / \mathrm{kg}$ depending on the financing technique that is employed. The recommended cost for comparison with other fuel cycles and methods of fabrication is the typical industry cost of $\$ 130 / \mathrm{kg}$. 
Table 9.6. Summary of Costs for Fabrication of Sphere-Pac PWR Fuel in a 2-t HM/d Facility [NASAP Case 1.2 PWR- $\left({ }^{235} \mathrm{U}, \mathrm{U}\right) \mathrm{O}_{2}$ Extended Burnup]

\begin{tabular}{|c|c|c|c|c|c|c|c|c|c|}
\hline \multirow[b]{2}{*}{$\begin{array}{c}\text { Economic } \\
\text { Set }^{a}\end{array}$} & \multicolumn{4}{|c|}{ Estimated Costs, $\$$ million } & \multicolumn{4}{|c|}{ Derived Costs, $\$$ million } & \multirow[b]{2}{*}{$\begin{array}{c}\text { Unit } \\
\text { Cost } \\
(\$ / \mathrm{kg})\end{array}$} \\
\hline & Facility & Equipment & $\begin{array}{c}\text { Annual } \\
\text { Hardware } \\
\text { Plus } \\
\text { Materials }\end{array}$ & $\begin{array}{c}\text { Annual } \\
\text { Operating }\end{array}$ & $\begin{array}{l}\text { Owner's } \\
\text { Cost } \\
\text { During } \\
\text { Construction }\end{array}$ & $\begin{array}{c}\text { Charge on } \\
\text { Direct Capital } \\
\text { During } \\
\text { Construction }\end{array}$ & $\begin{array}{c}\text { Annual } \\
\text { Equipment } \\
\text { Replacement } \\
\text { Cost }\end{array}$ & $\begin{array}{c}\text { Annual } \\
\text { Payment to } \\
\text { Decommissioning } \\
\text { Fund }\end{array}$ & \\
\hline A & 31 & 35 & 25 & 14 & 21 & 21 & 1.7 & 0.7 & 100 \\
\hline B & 31 & 35 & 25 & 15 & 21 & 30 & 1.7 & 0.7 & 130 \\
\hline $\mathrm{C}$ & 31 & 35 & 25 & 15 & 22 & 31 & 1.7 & 0.7 & 150 \\
\hline
\end{tabular}

$a_{\mathrm{A}}=$ Government financing; $\mathrm{B}=$ Typical industrial financing; $\mathrm{C}=$ High-risk industrial financing. 
9.2 NASAP CASE 1.3 - PWR SPIKED ( U, Pu) 2 REFABRICATION

[PWR LEU(5)-PU SPIKED RECYCLE]

\subsubsection{Fuel Cyc1e Description}

This reactor-fuel cycle combination is a PWR using $3 \%$-enriched uranium oxide pellet fuel and self-generated recycle fuel of partially partitioned uranium and plutonium, which is spiked with $60^{\circ} \mathrm{Co}$. Fresh makeup fuel is LEU(5). Excess uranium from reprocessing is recycled to enrichment.

In this assessment only the refabrication processes are addressed. The reprocessing plant provides the coarse and medium particles as a mixed uranium-plutonium product containing the cobalt spike. Consequently this requires the refabrication plant to be remotely operated and remotely maintained (RO/RM). This case is essentially that used in developing the generic assessment.

\subsubsection{Applicability to Current Fuel Element Design}

There are a number of existing pressurized-water reactor fuel element designs, and all of them are similar in their requirements for fuel rod loading. For this analysis, the representative design chosen for this case is presented in Table 9.7.

The key considerations for sphere-pac applicability are the cladding inside diameter measurements and the required fuel smear density. The cladding ID of $8433 \mu \mathrm{m}$ in the reference design is suitable for the spherepac process. In addition, since the design smear density of $88 \%$ is essentially that achieved with experimental blended (three particle size) sphere-pac beds, the process is applicable.

\subsubsection{Definition of Plant Production Requirements and Design Capacity}

For the PWR (U,Pu)O $)_{2}$ fuel cycle, the plant design assumptions are as follows. 
Table 9.7. Summary of C-E System 80 PWR $16 \times 16$ Fuel Assembly Parameters [NASAP Case 1.3 - PWR LEU(5)-Pu Spiked Recycle]

\begin{tabular}{|c|c|c|c|}
\hline \multirow[t]{2}{*}{$\begin{array}{l}\text { Reactor power } \\
\text { Fuel assemblies/core } \\
\text { Reload cycle }\end{array}$} & \multicolumn{3}{|c|}{$\begin{array}{l}1300 \text { MWe (net) } \\
241 \\
\text { Annual ( } 1 / 3 \text { per reload) }\end{array}$} \\
\hline & Materials & $\begin{array}{c}\text { Number per } \\
\text { Fuel Assemb1y }\end{array}$ & $\begin{array}{l}\text { Mass per Fue } 1 \\
\text { Assembly, kg }\end{array}$ \\
\hline $\begin{array}{l}\text { Cladding } \\
\text { End plugs }\end{array}$ & Zircaloy-4 & 236 & 113.47 \\
\hline Top & Zircaloy-4 & 236 & 0.80 \\
\hline Bottom & Zircaloy-4 & 236 & 1.04 \\
\hline $\begin{array}{l}\text { Plenum springs } \\
\text { Guide tubes }\end{array}$ & 302 SS & 236 & 7.33 \\
\hline Instrument & Zircaloy-4 & 1 & 2.10 \\
\hline $\begin{array}{l}\text { Control element } \\
\text { Spacer grids }\end{array}$ & Zircaloy-4 & 4 & 8.85 \\
\hline Top & Zircaloy -4 & 1 & 0.82 \\
\hline Middle & Zircaloy -4 & 10 & 8.62 \\
\hline Bottom & Alloy 625 & 1 & 1.00 \\
\hline End fittings & & & \\
\hline Top & $\begin{array}{l}304 \text { sS with alloy } \\
\text { X-750 hold-down } \\
\text { springs }\end{array}$ & 1 & 18.60 \\
\hline $\begin{array}{l}\text { Bottom } \\
\text { Insulator pellets }\end{array}$ & $\begin{array}{l}\mathrm{CF}-8 \mathrm{SS} \\
\mathrm{Al}_{2} \mathrm{O}_{3}\end{array}$ & $\begin{array}{r}1 \\
472\end{array}$ & $\begin{array}{l}5.63 \\
1.18\end{array}$ \\
\hline
\end{tabular}

Fue1 Rod Characteristics

$\begin{array}{ll}\text { Cladding outside diameter } & 9.70 \mathrm{~mm}(0.382 \mathrm{in.}) \\ \text { Cladding inside diameter } & 8.43 \mathrm{~mm}(0.332 \mathrm{in.}) \\ \text { Fuel rod length } & 4.11 \mathrm{~m}(162 \mathrm{in.}) \\ \text { Fuel column height } & 3.81 \mathrm{~m}(150 \mathrm{in.}) \\ \text { Fuel smear density } & 88 \% \mathrm{T.D} \\ \text { Pellet diameter } & 8.26 \mathrm{~mm}(0.325 \mathrm{in.}) \\ \text { Pellet length } & 9.91 \mathrm{~mm}(0.390 \mathrm{in.})\end{array}$

Fuel Assembly Characteristics

$\begin{array}{ll}\text { Array } & 16 \times 16 \text { square } \\ \text { Dimensions } & \\ \quad \text { Width } & 203 \mathrm{~mm}(7.98 \mathrm{in.}) \\ \quad \text { Length } & 4.49 \mathrm{~m}(177 \mathrm{in.}) \\ \begin{array}{l}\text { Mass of structural } \\ \quad \text { components }\end{array} & 169.73 \mathrm{~kg} \\ \text { Heavy metal content } & 427 \mathrm{~kg}\end{array}$


1. The fuel design is the Combustion Engineering System $8016 \times 16$ rod array fuel assembly.

2. The plant production capacity is $480 \mathrm{t} \mathrm{HM} /$ year with the capability for simultaneous production of three enrichments.

3. The plant factor is 240 effective ful1-production days per year.

4. Plant design capacity:

Overall

Each line of three
$730 \mathrm{t} \mathrm{HM} /$ year

about 5 fuel assemblies/d

$243 \mathrm{t} \mathrm{HM} /$ year

$0.67 \mathrm{t} \mathrm{HM} / \mathrm{d}$

369 fuel rods/d

1.6 fuel assemblies/d

5. Process design capacities are based on the line design capacities and the scrap and sample losses defined in Sect. 9.2.4.

6. The facilities are designed to discharge no liquid waste other than treated sanitary sewage.

7. All process buildings and critical auxiliary support are designed and constructed in accordance with current United States Nuclear Regulatory Commission licensing requirements. Shielding is provided to limit dose rates to operating and maintenance personnel to $0.25 \mathrm{millirem} / \mathrm{h}$.

\subsubsection{Estimates of Surge Storage Requirements, Scrap Production Rates, and Processing Rates for Functional Steps}

Given the plant design assumptions defined in Sect.9.2.3, further commercial plant characteristics were derived.

To achieve the annual production rates, an analysis of the plant surge storage requirements and normal inventory was made, and the results of this analysis are given in Table 9.8 .

Based on current technology and assuming reasonable extrapolations for commercial-scale developments, a preliminary estimate was made of the daily mass flows of heavy metal through the fabrication plant and the average production rate of heavy metal scrap materials from the various functional activities. These are presented in Table 9.9. 
Table 9.9. Heavy Metal Mass Flows and Average Scrap Production for a Sphere-Pac Fuel Fabrication Plant [NASAP Case 1.3 PWR LEU(5) - Pu Spiked Recycle]

\begin{tabular}{|c|c|c|c|c|c|c|}
\hline \multirow{3}{*}{ Processing Step } & \multicolumn{6}{|c|}{ Mass Flow, $\mathrm{kg} \mathrm{HM} / \mathrm{d}$} \\
\hline & \multicolumn{2}{|c|}{ Daily Throughput } & \multicolumn{2}{|c|}{ Clean Scrap $b$} & \multicolumn{2}{|c|}{ Reject Scrap ${ }^{C}$} \\
\hline & $(\mathrm{Pu}, \mathrm{U}) \mathrm{O}_{2}{ }^{a}$ & $\mathrm{UO}_{2}$ Fines & $(\mathrm{Pu}, \mathrm{U}) \mathrm{O}_{2}{ }^{a}$ & $\mathrm{UO}_{2}$ Fines & $(\mathrm{Pu}, \mathrm{U}) \mathrm{O}_{2}{ }^{\alpha}$ & $\mathrm{UO}_{2}$ Fines \\
\hline Receiving and storage & 1662.3 & $437.8^{d}$ & & & & \\
\hline Sampling and batch loading & 1660.6 & & & & 1.7 & \\
\hline Weighing and sampling & & 437.4 & & & & 0.4 \\
\hline Calcining and sintering & 1659.8 & & & & 0.8 & \\
\hline Sphere upgrading & $1753.1^{e}$ & & & & 49.8 & \\
\hline Sphere sampling & 1749.6 & & & & 3.5 & \\
\hline Sphere storage & 1749.6 & 437.4 & & & & \\
\hline Fuel rod loading & 1749.6 & 437.4 & & & & \\
\hline Fuel rod scanning & 1662.1 & 415.5 & 84.0 & 21.0 & 3.5 & 0.9 \\
\hline Top component insertion & 1658.4 & 414.6 & 3.3 & 0.8 & 0.3 & 0.1 \\
\hline Rod welding and $x$ ray & 1658.4 & 414.6 & f & $f$ & $f$ & $f$ \\
\hline Leak detection & 1658.4 & 414.6 & $f$ & $f$ & $f$ & $f$ \\
\hline Rod assay & 1625.3 & 406.3 & 31.5 & 7.9 & 1.7 & 0.4 \\
\hline Final rod inspection & 1608.4 & 402.1 & 16.3 & 4.1 & 0.7 & 0.2 \\
\hline Assembly inspection & 1600 & 400 & 8.0 & 2.0 & 0.3 & $\underline{0.1}$ \\
\hline Tota1 & 20 & & 143.1 & 35.8 & 62.3 & 2.1 \\
\hline
\end{tabular}

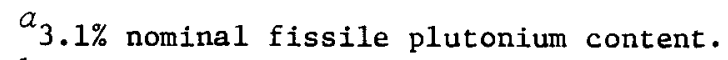

${ }^{b}$ Internally recycled.

${ }^{c}$ Collected, assayed, and externally recycled to reprocessing plant.

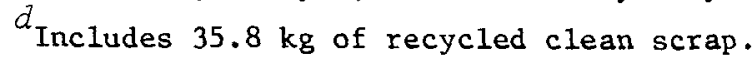

$e^{e}$ Includes $143.1 \mathrm{~kg}$ of recycled clean scrap.

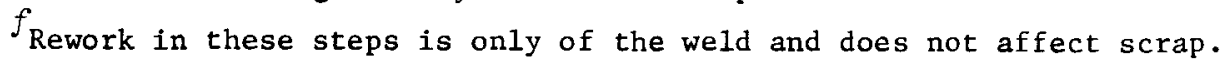


Table 9.8. Sphere-Pac Fabrication Plant Surge Storage Requirements and Normal Inventory [NASAP Case 1.3 PWR LEU(5) - Pu Spiked Recycle]

\begin{tabular}{|c|c|c|c|c|c|}
\hline \multirow{2}{*}{ Process Step } & \multirow{2}{*}{ Material } & \multicolumn{2}{|c|}{$\begin{array}{c}\text { Storage } \\
\text { Interval, } \mathrm{d}\end{array}$} & \multicolumn{2}{|c|}{ Normal Inventory, $\mathrm{kg} \mathrm{HM}$} \\
\hline & & Normal & Maximum & $(\mathrm{Pu}, \mathrm{U}) \mathrm{O}_{2}{ }^{\alpha}$ & $\mathrm{UO}_{2}$ Fines \\
\hline Feed storage & $\begin{array}{l}\text { Dried spheres } \\
\text { Sintered spheres }\end{array}$ & $\begin{array}{l}30 \\
30\end{array}$ & $\begin{array}{l}60 \\
60\end{array}$ & 50,000 & 13,000 \\
\hline Interim storage & $\begin{array}{l}\text { Dried spheres } \\
\text { Sintered spheres }\end{array}$ & $\begin{array}{l}1 \\
1\end{array}$ & $\begin{array}{l}2 \\
2\end{array}$ & 1,660 & 440 \\
\hline Furnace & $\begin{array}{l}\text { Dried to sintered } \\
\text { spheres }\end{array}$ & 1.2 & 2.4 & 2,000 & \\
\hline Post furnace & Sintered spheres & 0.5 & 1 & 830 & \\
\hline Interim storage & Sintered spheres & 0.36 & 0.72 & 600 & \\
\hline Main storage & $\begin{array}{l}\text { Sintered spheres } \\
\text { Sintered spheres }\end{array}$ & $\begin{array}{l}1.2 \\
1.5\end{array}$ & $\begin{array}{l}2.4 \\
2.9\end{array}$ & 2,100 & 660 \\
\hline $\begin{array}{l}\text { Loading, inspection } \\
\text { welding }\end{array}$ & Sintered spheres & 0.12 & 0.24 & 210 & 50 \\
\hline $\begin{array}{l}\text { Loaded, not inspected } \\
\text { rods }\end{array}$ & $\begin{array}{l}\text { Sintered spheres } \\
\text { in rods }\end{array}$ & 5 & 5 & 8,300 & 2,070 \\
\hline Rework and scrap & Sintered spheres & 2 & 5 & 410 & 75 \\
\hline Completed fuel rods & $\begin{array}{l}\text { Sintered spheres } \\
\text { in rods }\end{array}$ & 5 & 5 & 8,000 & 2,000 \\
\hline Assembly & $\begin{array}{l}\text { Rods in completed } \\
\text { assemblies }\end{array}$ & 15 & 30 & 24,000 & 6,000 \\
\hline
\end{tabular}

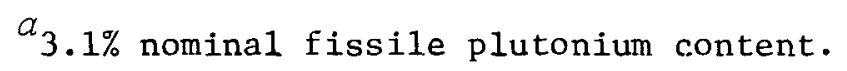


Given the above information, a preliminary evaluation of the processing rates for each functional step within the main fuel fabrication processes was made. The results of this analysis are summarized in Table 9.10.

\subsubsection{Analysis of Functiona1 Technology Status, Research and Development Requirements, Cost, and Schedule}

Reference case - see Sect. 8 of this report. The current status is summarized in Table 9.11 with the cost estimate.

\subsubsection{Preliminary Cost Estimate for Construction and Operation of a Commercial-Scale Plant}

The cost components that were estimated include capital costs for the facility and equipment, fuel assembly hardware costs, material and supply costs, and operating costs. ${ }^{1-3}$ These cost estimates include the $\mathrm{UO}_{2}$ sphere-forming operations. These operations require an addition to the plant beyond that shown in the reference case to receive $\mathrm{UF}_{6}$ and process it to dried spheres. This has been included in the cost estimate.

Facility capital cost estimates were based on an analysis of the functional flow diagram for the process to indicate space requirements for each functional area and for each support area. Equipment requirements were Identified, and costs associated with the equipment were estimated. Fuel assembly hardware requirements were based on the reference fuel assembly design parameters identified in Table 9.7. Estimates of the costs of the hardware items were obtained. Material and supply requirements were identified from the sphere-pac process description, and estimates of the costs of materials and supplies were obtained. Operating cost estimates included consideration of personnel, overhead, general and administrative expenses, and costs of utilities.

The facility was assumed to operate as a toll processing facility. That is, the operator fabricates customer-supplied fuel feed materials into finished fuel assemblies, and thus costs of plutonium and uranium 
Table 9.10. Equipment Requirements for Functional Areas [NASAP Case 1.3 PWR LEU(5) - Pu Spiked Recycle]

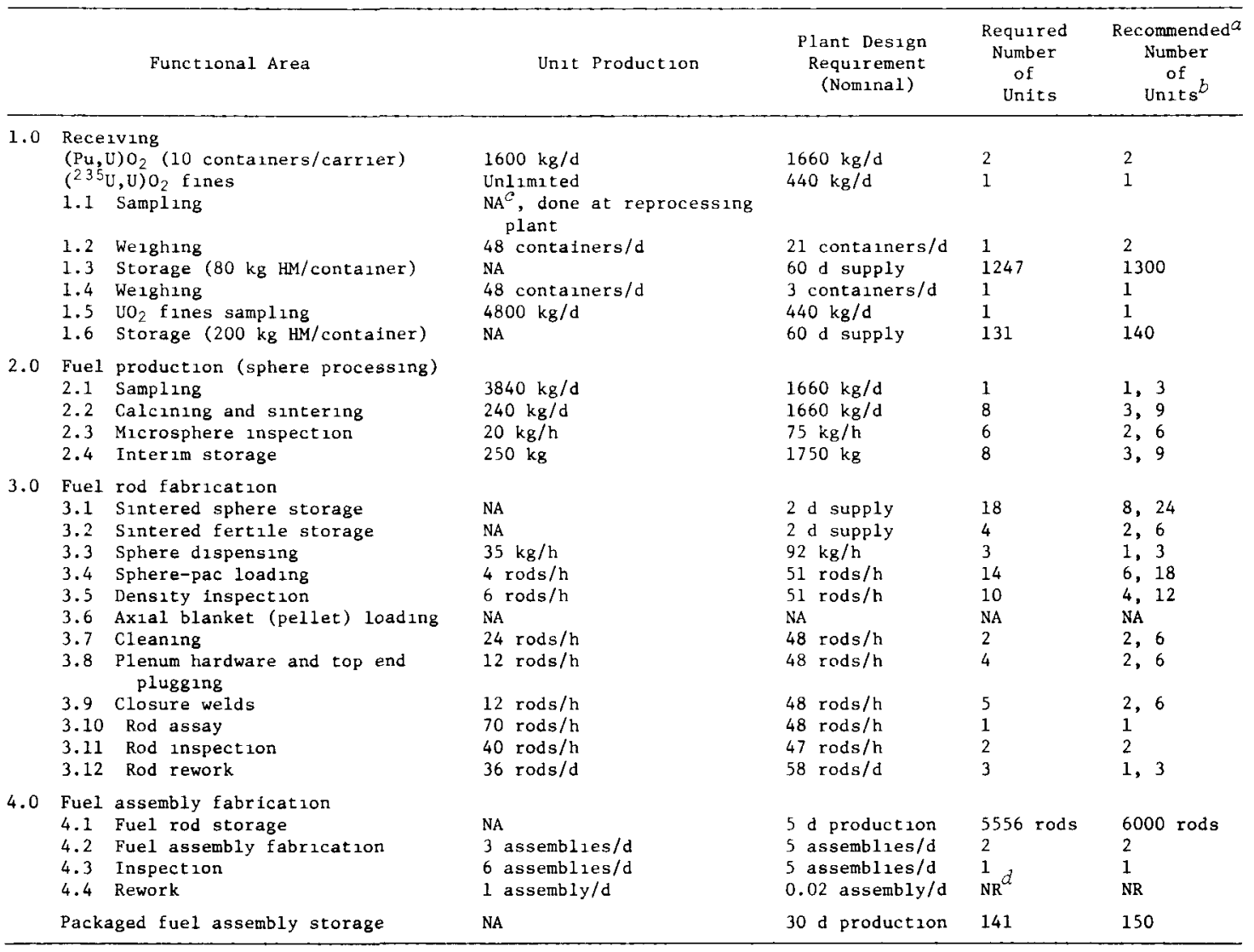

a Recommended units include consideration of spare capacity for operational reliability.

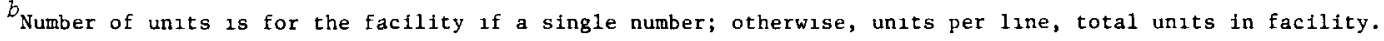
NA: not applicable.

$a_{\mathrm{NR}}$ not required. Use assembly equipment as avallable. 
Table 9.11. Research and Development Cost Estimates for Sphere-Pac Fabrication [NASAP Case 1.3 PWR LEU(5) - MOD OT]

\begin{tabular}{|c|c|c|c|c|}
\hline & $\mathrm{R} \& \mathrm{D}$ Categories & Current Status ${ }^{a}$ & $\begin{array}{c}\text { R\&D Cost Estimates } \\
\text { (Millions of } \\
1978 \$)\end{array}$ & $\begin{array}{l}\text { Years to } \\
\text { Complete }\end{array}$ \\
\hline 1.0 & Program management & Not applicable & 10 & 10 \\
\hline 2.0 & Design studies & $P-$ cold engineering & 25 & 10 \\
\hline 3.0 & Receiving and storage & $P-$ cold engineering & 3 & 5 \\
\hline 4.0 & Fuel production & $P-$ cold engineering & 30 & 8 \\
\hline 5.0 & Fuel rod fabrication & $P$ - cold engineering & 50 & 8 \\
\hline 6.0 & Fuel element assembly & $\mathrm{N}-$ cold engineering & 30 & 10 \\
\hline 7.0 & Scrap recovery & $N-$ cold engineering & 6 & 5 \\
\hline 8.0 & Waste treatment & $b$ & $b$ & $b$ \\
\hline 9.0 & Plant control systems & $N$ - cold prototype & 5 & 8 \\
\hline 10.0 & Maintenance & $\mathrm{N}-\operatorname{cold}$ engineering & 10 & 10 \\
\hline 11.0 & $\begin{array}{l}\text { Safeguards and account- } \\
\text { ability adaptation }\end{array}$ & $P-\operatorname{cold}$ engineering & 6 & 6 \\
\hline & Subtotal & & 175 & \\
\hline \multicolumn{5}{|c|}{ Special Facilities } \\
\hline \multicolumn{3}{|c|}{ Hot tests } & 10 & \\
\hline \multirow[t]{3}{*}{ Cold } & prototype & & 25 & \\
\hline & Total & & $210^{d}$ & \\
\hline & Range & & $200-250$ & \\
\hline
\end{tabular}

\footnotetext{
${ }^{a}$ Status stage with qualitative modifiers; $\mathrm{C}=$ complete, $\mathrm{P}=$ in progress, and $\mathrm{N}=$ needed.

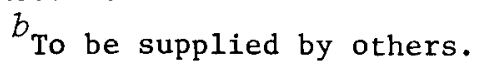

${ }^{c}$ Assumes basic technology as developed under oss estimate presented is for applications testing, systems integraton, and testing.

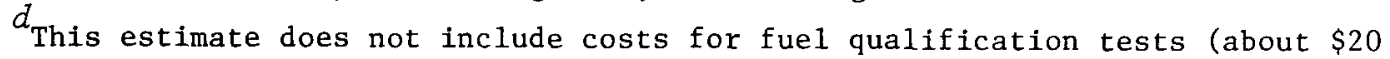
million) or the capital costs of a pilot plant estimated at $\$ 190$ million.
} 
were not included in the cost estimates. The hardware and material costs do include the costs associated wih the production of the depleted or natural $\mathrm{UO}_{2}$ spheres.

Unit costs for fabrication of fuel assemblies are determined by an economic analysis of the basic capital, hardware and material, and operating cost estimates. Basically, the economic analysis provides for the owner of the fuel fabrication facility to recover all capital, operating, and finance charges plus a return on investment, if appropriate, over the life of the plant.

In order to provide a range of prices (i.e., costs to a customer), economic analyses were based on government financing, financing appropriate for a conventional-risk (typical) industry, and financing appropriate for a high-risk industry. 2 The estimated costs, costs derived from the economic analysis, and the unit costs based on the three different financing methods are summarized in Table 9.12. As may be observed from the table, the price for fabrication of spiked $(\mathrm{Pu}, \mathrm{U}) \mathrm{O}_{2}$ fuel is expected to be in the range from $\$ 330$ to $\$ 740 / \mathrm{kg}$ depending on the financing technique that is employed. The recommended cost for comparison with other fuel cycles and methods of fabrication is the typical industry price of $\$ 570 / \mathrm{kg}$. 
Table 9.12. Summary of Costs for Fabrication of Sphere-Pac PWR Fuel in a 2-t HM/d Facility [NASAP Case 1.3 PWR Spiked (Pu,U) $\mathrm{O}_{2}$ Refabrication]

\begin{tabular}{|c|c|c|c|c|c|c|c|c|c|}
\hline \multirow[b]{2}{*}{$\begin{array}{l}\text { Economic } \\
\text { Set }{ }^{a}\end{array}$} & \multicolumn{4}{|c|}{ Estimated Costs, $\$$ million } & \multicolumn{4}{|c|}{ Derived Costs, $\$$ million } & \multirow[b]{2}{*}{$\begin{array}{c}\text { Unit } \\
\text { Cost } \\
(\$ / \mathrm{kg})\end{array}$} \\
\hline & Facility & Equipment & $\begin{array}{l}\text { Annual } \\
\text { Hardware } \\
\text { Plus } \\
\text { Materials }\end{array}$ & $\begin{array}{c}\text { Annual } \\
\text { Operating }\end{array}$ & $\begin{array}{c}\text { Owner's } \\
\text { Cost } \\
\text { During } \\
\text { Construction }\end{array}$ & $\begin{array}{c}\text { Charge on } \\
\text { Direct Capital } \\
\text { During } \\
\text { Construction }\end{array}$ & $\begin{array}{c}\text { Annual } \\
\text { Equipment } \\
\text { Replacement } \\
\text { Cost }\end{array}$ & $\begin{array}{c}\text { Annual } \\
\text { Payment to } \\
\text { Decommissioning } \\
\text { Fund }\end{array}$ & \\
\hline A & 360 & 260 & 30 & 26 & 38 & 160 & 13 & 1.2 & 330 \\
\hline B & 360 & 260 & 30 & 27 & 39 & 240 & 13 & 1.2 & 570 \\
\hline $\mathrm{C}$ & 360 & 260 & 30 & 27 & 39 & 240 & 13 & 1.2 & 740 \\
\hline
\end{tabular}

$a_{\mathrm{A}}=$ Government financing; $\mathrm{B}=$ Typical industrial financing; $\mathrm{C}=$ High-risk industrial financing. 
9.3 NASAP CASE 1.4 - PWR (233U, U, Th) $)_{2}$ FABRICATION AND REFABRICATION [PWR DU(3)-Th RECYCLE DU(3)]

\subsubsection{Fue1 Cycle Description}

This reactor-fuel cycle combination is a PWR using $233_{\mathrm{U}}$ denatured with $238_{\mathrm{U}}$ and mixed with thorium oxide to fabricate pellet recycle fuel. The spent fuel is reprocessed to recover the $233_{\mathrm{U}}-238_{\mathrm{U}}$, which is blended with additional $233_{\mathrm{U}}$ from a secure storage center. Recovered plutonium is spiked and sold to a secure storage center.

Since both initial fuel and recycle fuel contain $233 \mathrm{U}$ with some unidentified quantity of $232 \mathrm{U}$, we can assume that the fuel will be highly radioactive. Consequently the fabrication and refabrication plants are the same. Both require a remotely operated and remotely maintained (RO/RM) process.

In the cycle as defined only fresh thorium is used in the fabrication processes. This will have to be added to the denatured $233 \mathrm{U}$ solutions before the sphere-forming process to provide the appropriate uranium-tothorium ratio for the coarse and medium particles for the ge1-sphere-pac process. This will be done at the reprocessing plant during sphere forming and conversion.

\subsubsection{Applicability to Current Fuel Element Design}

There are a number of existing pressurized-water reactor fuel element designs, and all of them are similar in their requirements for fuel rod loading. For this analysis, the representative design chosen for this case is presented in Table 9.13.

The key considerations for sphere-pac applicability are the cladding inside diameter measurements and the required fuel smear density. The cladding ID of $8433 \mu \mathrm{m}$ in the reference design is suitable for the spherepac process. In addition, since the design smear density of $88 \%$ is essentially that achieved with experimental blended (three particle size) sphere-pac beds, the process is applicable. 
Table 9.13. Summary of C-E System 80 PWR $16 \times 16$ Fuel Assembly Parameters [NASAP Case 1.4 PWR DU(3)-Th Recycle DU(3)]

\begin{tabular}{|c|c|c|c|}
\hline $\begin{array}{l}\text { Reactor power } \\
\text { Fuel assemblies/core } \\
\text { Reload cycle }\end{array}$ & $\begin{array}{l}1300 \text { MWe (net) } \\
241 \\
\text { Annual ( } 1 / 3 \text { per rel }\end{array}$ & ad) & \\
\hline Component Characteristics & Materia1s & $\begin{array}{c}\text { Number per } \\
\text { Fue1 Assembly } \\
\end{array}$ & $\begin{array}{l}\text { Mass per Fue1 } \\
\text { Assembly, kg }\end{array}$ \\
\hline $\begin{array}{l}\text { Cladding } \\
\text { End plugs }\end{array}$ & Zircaloy -4 & 236 & 113.47 \\
\hline Top & Zircaloy -4 & 236 & 0.80 \\
\hline Bottom & Zircaloy -4 & 236 & 1.04 \\
\hline $\begin{array}{l}\text { Plenum springs } \\
\text { Guide tubes }\end{array}$ & 302 SS & 236 & 7.33 \\
\hline Instrument & Zircaloy -4 & 1 & 2.10 \\
\hline $\begin{array}{l}\text { Control element } \\
\text { Spacer grids }\end{array}$ & Zircaloy -4 & 4 & 8.85 \\
\hline Top & Zircaloy -4 & 1 & 0.82 \\
\hline Middle & Zircaloy -4 & 10 & 8.62 \\
\hline $\begin{array}{l}\text { Bottom } \\
\text { End fittings }\end{array}$ & Alloy 625 & 1 & 1.00 \\
\hline $\begin{array}{l}\text { End tittings } \\
\text { Top }\end{array}$ & $\begin{array}{l}304 \text { SS with alloy } \\
\mathrm{X}-750 \text { hold-down } \\
\text { springs }\end{array}$ & 1 & 18.60 \\
\hline $\begin{array}{l}\text { Bottom } \\
\text { Insulator pellets }\end{array}$ & $\begin{array}{l}\mathrm{CF}-8 \mathrm{SS} \\
\mathrm{Al}_{2} \mathrm{O}_{3}\end{array}$ & $\begin{array}{r}1 \\
472\end{array}$ & $\begin{array}{l}5.63 \\
1.18\end{array}$ \\
\hline
\end{tabular}

Fuel Rod Characteristics

Cladding outside diameter Cladding inside diameter Fuel rod length Fuel column height Fuel smear density Pellet diameter Pellet length

$$
\begin{aligned}
& 9.70 \mathrm{~mm}(0.382 \mathrm{in.}) \\
& 8.43 \mathrm{~mm}(0.332 \mathrm{in.}) \\
& 4.11 \mathrm{~m}(162 \mathrm{in.}) \\
& 3.81 \mathrm{~m}(150 \mathrm{in.}) \\
& 88 \% \mathrm{T.D} \text {. } \\
& 8.26 \mathrm{~mm}(0.325 \mathrm{in.}) \\
& 9.91 \mathrm{~mm}(0.390 \mathrm{in.})
\end{aligned}
$$

Fuel Assembly Characteristics

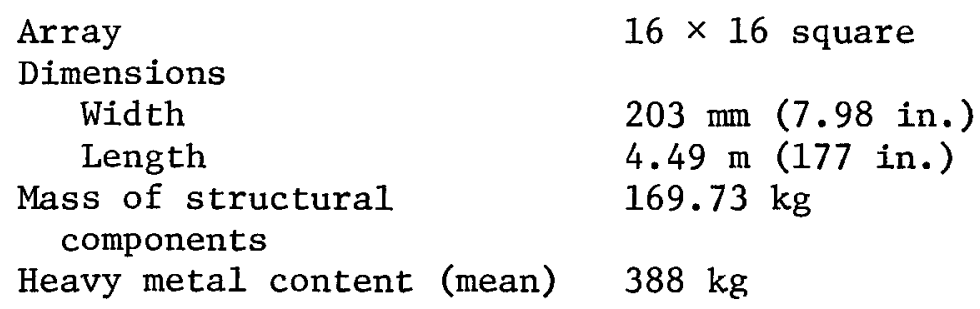

Heavy metal content (mean) $388 \mathrm{~kg}$

$16 \times 16$ square

$203 \mathrm{~mm}$ (7.98 in.) $4.49 \mathrm{~m}$ (177 in.)

$169.73 \mathrm{~kg}$ 
9.3.3 Definition of Plant Production Requirements and Design Capacity

For the PWR $\left({ }^{233} \mathrm{U}, \mathrm{Th}\right) \mathrm{O}_{2}$ fuel cycle, the plant design assumptions are as follows.

1. The fuel design is the Combustion Engineering System $8016 \times 16$ rod array fuel assembly.

2. The plant production capacity is $480 \mathrm{t}$ HM/year with the capability for simultaneous production of three enrichments.

3. The plant factor is 240 effective ful1-production days per year.

4. Plant design capacity:

Overall

Each line of three
$730 \mathrm{t} \mathrm{HM} /$ year

about 5 fue1 assemblies/d

$243 \mathrm{t} \mathrm{HM} /$ year

$0.67 \mathrm{t} \mathrm{HM} / \mathrm{d}$

406 fuel rods/d

1.7 fuel assemblies/d

5. Process design capacities are based on the line design capacities and the scrap and sample losses defined in Sect. 9.3.4.

6. The facilities are designed to discharge no liquid waste other than treated sanitary sewage.

7. A11 process buildings and critical auxiliary support are designed and constructed in accordance with current United States Nuclear Regulatory Commission licensing requirements. Shielding is provided to limit dose rates to operating and maintenance personnel to $0.25 \mathrm{millirem} / \mathrm{h}$.

\subsubsection{Estimates of Surge Storage Requirements, Scrap Production Rates, and Processing Rates for Functional Steps}

Given the plant design assumptions defined in Sect.9.3.3, further commercial plant characteristics were derived.

To achieve the annual production rates, an analysis of the plant surge storage requirements and normal inventory was made, and the results of this analysis are given in Table 9.14. 
Table 9.14. Sphere-Pac Fabrication Plant Surge Storage Requirements and Normal Inventory [NASAP Case 1.4 PWR DU(3) - Th Recycle DU(3)]

\begin{tabular}{|c|c|c|c|c|c|}
\hline \multirow{2}{*}{ Process Step } & \multirow{2}{*}{ Material } & \multicolumn{2}{|c|}{$\begin{array}{c}\text { Storage } \\
\text { Interval, } \mathrm{d}\end{array}$} & \multicolumn{2}{|c|}{ Norma1 Inventory, $\mathrm{kg} \mathrm{HM}$} \\
\hline & & Normal & Maximum & $\left({ }^{233} \mathrm{U}, \mathrm{U}\right) \mathrm{O}_{2}$ & $\mathrm{ThO}_{2}$ Fines \\
\hline Feed storage & $\begin{array}{l}\text { Dried spheres } \\
\text { Sintered spheres }\end{array}$ & $\begin{array}{l}30 \\
30\end{array}$ & $\begin{array}{l}60 \\
60\end{array}$ & 50,000 & 13,000 \\
\hline Interim storage & $\begin{array}{l}\text { Dried spheres } \\
\text { Sintered spheres }\end{array}$ & $\begin{array}{l}1 \\
1\end{array}$ & $\begin{array}{l}2 \\
2\end{array}$ & 1,660 & 440 \\
\hline Furnace & $\begin{array}{l}\text { Dried to sintered } \\
\text { spheres }\end{array}$ & 1.2 & 2.4 & 2,000 & \\
\hline Post furnace & Sintered spheres & 0.5 & 1 & 830 & \\
\hline Interim storage & Sintered spheres & 0.36 & 0.72 & 600 & \\
\hline Main storage & $\begin{array}{l}\text { Sintered spheres } \\
\text { Sintered spheres }\end{array}$ & $\begin{array}{l}1.2 \\
1.5\end{array}$ & $\begin{array}{l}2.4 \\
2.9\end{array}$ & 2,100 & 660 \\
\hline $\begin{array}{l}\text { Loading, inspection } \\
\text { welding }\end{array}$ & Sintered spheres & 0.12 & 0.24 & 210 & 50 \\
\hline $\begin{array}{l}\text { Loaded, not inspected } \\
\text { rods }\end{array}$ & $\begin{array}{l}\text { Sintered spheres } \\
\text { in rods }\end{array}$ & 5 & 5 & 8,300 & 2,070 \\
\hline Rework and scrap & Sintered spheres & 2 & 5 & 410 & 75 \\
\hline Completed fuel rods & $\begin{array}{l}\text { Sintered spheres } \\
\text { in rods }\end{array}$ & 5 & 5 & 8,000 & 2,000 \\
\hline Assembly & $\begin{array}{l}\text { Rods in completed } \\
\text { assemblies }\end{array}$ & 15 & 30 & 24,000 & 6,000 \\
\hline
\end{tabular}

$a_{12 \%}$ nominal enrichment $\left({ }^{23} \mathrm{U}\right)$ 
Based on current technology and assuming reasonable extrapolations for commercial-scale developments, a preliminary estimate was made of the daily mass flows of heavy metal through the fabrication plant and the average production rate of heavy metal scrap materials from the various functional activities. These are presented in Table 9.15.

Given the above information, a preliminary evaluation of the processing rates for each functional step within the main fuel fabrication processes was made. The results of this analysis are summarized in Table 9.16 .

\subsubsection{Analysis of Functional Technology Status, Research and Development Requirements, Cost, and Schedule}

The technology status of this system is quite similar to that of the reference case discussed in Sect. 8. The current status and research and development needs are summarized in Table 9.17. The primary difference between this denatured $233 \mathrm{U}-\mathrm{Th}$ fuel and the $\mathrm{U}-\mathrm{Pu}$ fuel is the level of current development effort on sphere forming, calcination, and sintering. Currently $(\mathrm{U}, \mathrm{Pu})_{2}$ is under investigation in the United States, and the $U-T h$ system would need to be initiated at the U/Th ratio required for this fuel. However, the process development studies could be accomplished with greater ease if natural or depleted uranium were used. Thus, the overall schedule would be essentially unchanged. Only a slight decrease in total research and development costs would be possible, in the range from 3 to $5 \%$, because the hot engineering-scale tests would still be required.

\subsubsection{Preliminary Cost Estimate for Construction and Operation of a Commercial-Scale Plant}

The cost components that were estimated include capital costs for the facility and equipment, fuel assembly hardware costs, material and supply costs, and operating costs.1-3

Facility capital cost estimates were based on an analysis of the functional flow diagram for the process to indicate space requirements for each functional area and for each support area. Equipment requirements were identified, and costs associated with the equipment were estimated. 
Table 9.15. Heavy Metal Mass Flows and Average Scrap Production for a Sphere-Pac Fuel Fabrication Plant [NASAP Case 1.4 PWR DU(3) - Th Recycle DU(3)]

\begin{tabular}{|c|c|c|c|c|c|c|}
\hline \multirow{3}{*}{ Processing Step } & \multicolumn{6}{|c|}{ Mass Flow, kg HM/d } \\
\hline & \multicolumn{2}{|c|}{ Daily Throughput } & \multicolumn{2}{|c|}{ Clean Scrap $b$} & \multicolumn{2}{|c|}{ Reject Scrap ${ }^{C}$} \\
\hline & $\left({ }^{233} \mathrm{U}, \mathrm{U}, \mathrm{Th}\right) \mathrm{O}_{2}{ }^{a}$ & $\mathrm{UO}_{2}$ Fines & $\left({ }^{23}{ }^{3} \mathrm{U}, \mathrm{U}, \mathrm{Th}\right) \mathrm{O}_{2}{ }^{a}$ & $\mathrm{UO}_{2}$ Fines & $\left({ }^{23}{ }^{3} \mathrm{U}, \mathrm{U}, \mathrm{Th}\right) \mathrm{O}_{2}{ }^{a}$ & $\mathrm{UO}_{2}$ Fines \\
\hline Receiving and storage & 1662.3 & $437.8^{d}$ & & & & \\
\hline Sampling and batch loading & 1660.6 & & & & 1.7 & \\
\hline Weighing and sampling & & 437.4 & & & & 0.4 \\
\hline Calcining and sintering & 1659.8 & & & & 0.8 & \\
\hline Sphere upgrading & $1753.1^{e}$ & & & & 49.8 & \\
\hline Sphere sampling & 1749.6 & & & & 3.5 & \\
\hline Sphere storage & 1749.6 & 437.4 & & & & \\
\hline Fuel rod loading & 1749.6 & 437.4 & & & & \\
\hline Fuel rod scanning & 1662.1 & 415.5 & 84.0 & 21.0 & 3.5 & 0.9 \\
\hline Top component insertion & 1658.4 & 414.6 & 3.3 & 0.8 & 0.3 & 0.1 \\
\hline Rod welding and $x$ ray & 1658.4 & 414.6 & $f$ & $f$ & $f$ & $f$ \\
\hline Leak detection & 1658.4 & 414.6 & $f$ & $f$ & $f$ & $f$ \\
\hline Rod assay & 1625.3 & 406.3 & 31.5 & 7.9 & 1.7 & 0.4 \\
\hline Final rod inspection & 1608.4 & 402.1 & 16.3 & 4.1 & 0.7 & 0.2 \\
\hline Assembly inspection & 1600 & 400 & 8.0 & 2.0 & 0.3 & $\underline{0.1}$ \\
\hline Tota1 & 2000 & & 143.1 & 35.8 & 62.3 & 2.1 \\
\hline
\end{tabular}

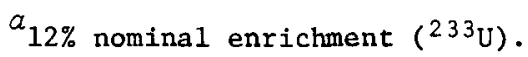

$b_{\text {Internally recycled. }}$

${ }^{c}$ Collected, assayed, and externally recycled to reprocessing plant.

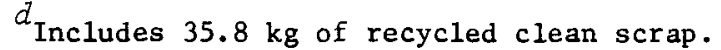

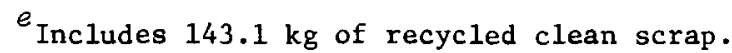

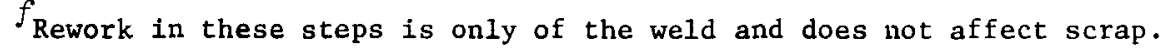


Table 9.16. Equipment Requirements for Functional Areas [NASAP Case 1.4 PWR DU(3) - Th Recycle DU(3)]

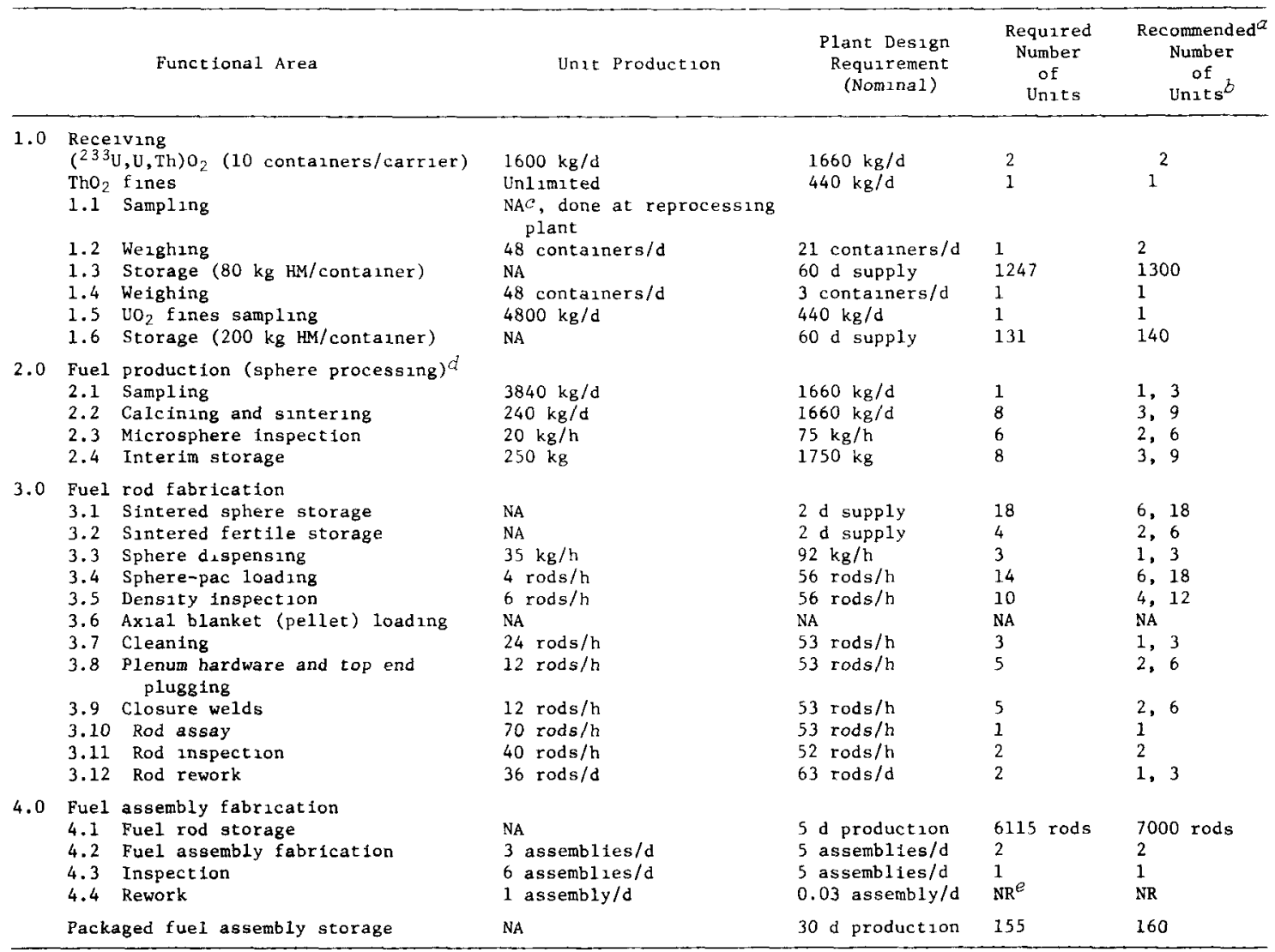

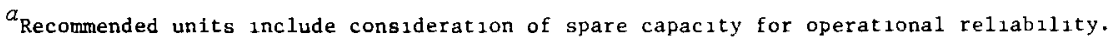

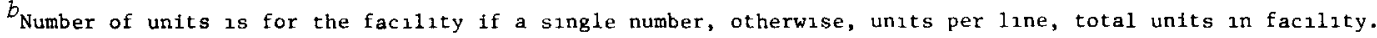
NA: not applicable.

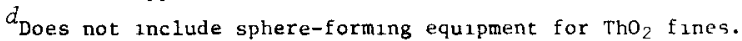

${ }^{e} \mathrm{NR}$ : not requared. Use assembly equipment as avallable. 
Table 9.17. Research and Development Cost Estimates for Sphere-Pac Fabrication [NASAP Case 1.4 PWR DU(3)-Th Recycle]

\begin{tabular}{|c|c|c|c|c|}
\hline & R\&D Categories & Current Status $^{a}$ & $\begin{array}{c}\text { R\&D Cost Estimates } \\
\text { (Mil1ions of } \\
1978 \text { \$) }\end{array}$ & $\begin{array}{l}\text { Years to } \\
\text { Complete }\end{array}$ \\
\hline 1.0 & Program management & Not applicable & 10 & 10 \\
\hline 2.0 & Design studies & $\mathrm{P}-\operatorname{cold}$ engineering & 25 & 10 \\
\hline 3.0 & Receiving and storage & $P-$ cold engineering & 3 & 5 \\
\hline 4.0 & Fuel production & P - hot laboratory & 30 & 8 \\
\hline 5.0 & Fuel rod fabrication & $P-\operatorname{cold}$ engineering & 50 & 8 \\
\hline 6.0 & Fuel element assembly & $\mathrm{N}-$ cold engineering & 30 & 10 \\
\hline 7.0 & Scrap recovery & $\mathrm{N}$ - hot 1aboratory & 7 & 5 \\
\hline 8.0 & Waste treatment & $b$ & $b$ & $b$ \\
\hline 9.0 & Plant control systems & $\mathrm{N}-$ cold prototype & 5 & 8 \\
\hline 10.0 & Maintenance & $\mathrm{N}-\operatorname{cold}$ engineering & 10 & 10 \\
\hline 11.0 & $\begin{array}{l}\text { Safeguards and account- } \\
\text { ability adaptation }\end{array}$ & $P-$ cold engineering & 6 & 6 \\
\hline & Subtota1 & & 176 & \\
\hline \multicolumn{5}{|c|}{ Special Facilities. } \\
\hline \multicolumn{3}{|c|}{ Hot tests } & 10 & \\
\hline \multicolumn{3}{|c|}{ Cold prototype } & 25 & \\
\hline & Total & & $211^{d}$ & \\
\hline & Range & & $200-250$ & \\
\hline
\end{tabular}

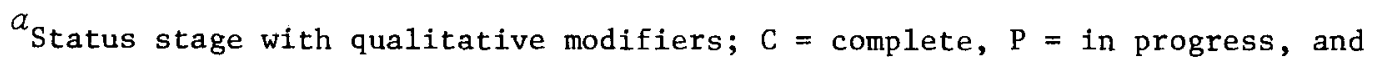
$\mathbf{N}=$ needed.

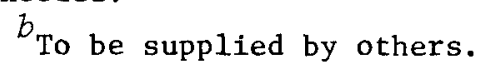

${ }^{c}$ Assumes basic technology as developed under oss estimate presented is for applications testing, systems integraton, and testing.

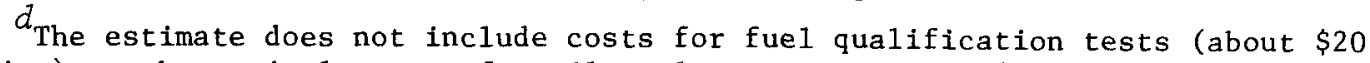
million) or the capital costs of a pilot plant estimated at $\$ 190$ million.
} 
Fuel assembly hardware requirements were based on the reference fuel assembly design parameters identified in Table 9.13. Estimates of the costs of the hardware items were obtained. Material and supply requirements were identified from the sphere-pac process description, and estimates of the costs of materials and supplies were obtained. Operating cost astimates included consideration of personnel, overhead, general and administrative expenses, and costs of utilities.

The facility was assumed to operate as a toll processing facility. That is, the operator fabricates customer-supplied fuel feed materials into finished fuel assemblies, and thus costs of uranium were not included in the cost estimates. The hardware and material costs do include the costs associated with the production of the fresh $\mathrm{ThO}_{2}$ fine size spheres.

Unit costs for fabrication of fuel assemblies are determined by an economic analysis of the basic capital, hardware and material, and operating cost estimates. Basically, the economic analysis provides for the owner of the fuel fabrication facility to recover all capital, operating, and finance charges plus a return on investment, if appropriate, over the life of the plant.

In order to provide a range of prices (i.e., costs to a customer), economic analyses were based on government financing, financing appropriate for a conventional-risk (typical) industry, and financing appropriate for a high-risk industry. ${ }^{2}$ The estimated costs, costs derived from the economic analysis, and the unit costs based on the three different financing methods are summarized in Table 9.18. As may be

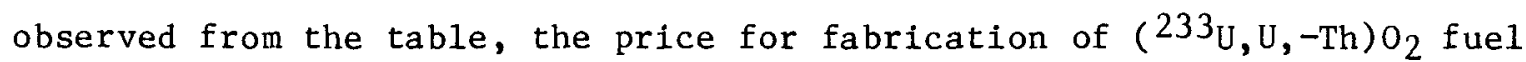
is expected to be in the range from $\$ 340$ to $\$ 750 / \mathrm{kg}$ depending on the financing technique that is employed. The recommended cost for comparison with other fuel cycles and methods of fabrication is the typical industry cost of $\$ 580 / \mathrm{kg}$. 
Table 9.18. Summary of Costs for Fabrication of Sphere-Pac PWR Fuel in a 2-t HM/d Facility [NASAP Case 1.4 PWR DU(3)-Th Recycle DU(3)]

\begin{tabular}{|c|c|c|c|c|c|c|c|c|c|}
\hline \multirow[b]{2}{*}{$\begin{array}{c}\text { Economic } \\
\text { Set } a\end{array}$} & \multicolumn{4}{|c|}{ Estimated Costs, $\$$ million } & \multicolumn{4}{|c|}{ Derived Costs, $\$$ million } & \multirow[b]{2}{*}{$\begin{array}{c}\text { Unit } \\
\text { Cost } \\
(\$ / \mathrm{kg})\end{array}$} \\
\hline & Facility & Equipment & $\begin{array}{c}\text { Annual } \\
\text { Hardware } \\
\text { Plus } \\
\text { Materials }\end{array}$ & $\begin{array}{c}\text { Annual } \\
\text { Operating }\end{array}$ & $\begin{array}{c}\text { Owner's } \\
\text { Cost } \\
\text { During } \\
\text { Construction }\end{array}$ & $\begin{array}{c}\text { Charge on } \\
\text { Direct Capital } \\
\text { During } \\
\text { Construction }\end{array}$ & $\begin{array}{c}\text { Annual } \\
\text { Equipment } \\
\text { Replacement } \\
\text { Cost }\end{array}$ & $\begin{array}{c}\text { Annual } \\
\text { Payment to } \\
\text { Decommissioning } \\
\text { Fund }\end{array}$ & \\
\hline A & 360 & 260 & 33 & 27 & 39 & 160 & 13 & 1.2 & 340 \\
\hline B & 360 & 260 & 33 & 27 & 40 & 240 & 13 & 1.3 & 580 \\
\hline $\mathrm{C}$ & 360 & 260 & 33 & 28 & 40 & 240 & 13 & 1.3 & 750 \\
\hline
\end{tabular}

$a_{\mathrm{A}}=$ Government financing; $\mathrm{B}=$ Typical industrial financing; $\mathrm{C}=$ High-risk industrial financing. 
9.4 NASAP CASE 1.5 - PWR (Pu,U)O 2 REFABRICATION [PWR-U-Pu]

\subsubsection{Fuel Cycle Description}

This example is a PWR using 3\%-enriched uranium oxide fuel and selfgenerated recycle fuel of partitioned uranium and plutonium oxide; GESMO fuel cycle.

Only the refabrication processes for $(\mathrm{Pu}, \mathrm{U}) \mathrm{O}_{2}$ fuels have been assessed for this cycle. The cycle specifies the complete separation of uranium and plutonium in the reprocessing plant. For the gel-sphere-pac option we have assumed that depleted or natural uranium solution is blended with the plutonium solution at the reprocessing plant before the conversion step. This will provide the appropriate plutonium-to-uranium ratio for the coarse and medium sphere sizes.

No spike is added to the fuel in this cycle, but the plutonium has significant radioactivity, so a remotely operated and contact-maintained (RO/CM) facility is required.

\subsubsection{Applicability to Current Fuel Element Design}

There are a number of existing pressurized-water reactor fuel element designs, and all of them are similar in their requirements for fuel rod loading. For this analysis, the representative design chosen for this case is presented in Table 9.19.

The key considerations for sphere-pac applicability are the cladding inside diameter measurements and the required fuel smear density. The cladding ID of $8433 \mu \mathrm{m}$ in the reference design is suitable for the spherepac process. In addition, since the design smear density of $88 \%$ is essentially that achieved with experimental blended (three particle size) sphere-pac beds, the process is applicable.

\subsubsection{Definition of Plant Production Requirements and Design Capacity}

For the PWR (U,Pu)O fuel cycle, the plant design assumptions are as follows. 
Table 9.19. Summary of C-E System 80 PWR $16 \times 16$ Fuel Assembly Parameters [NASAP Case $1.5-$ PWR-U-Pu]

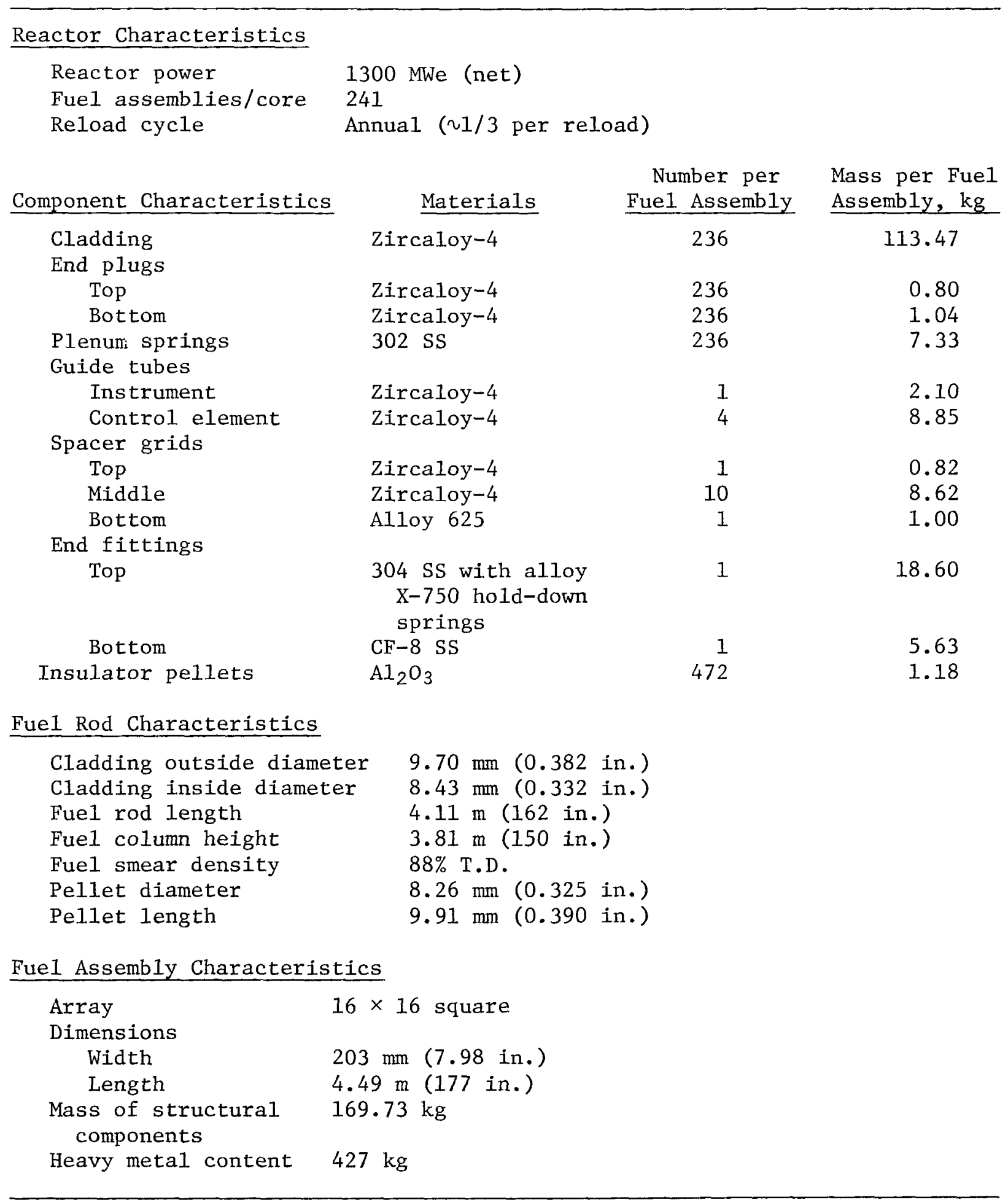


1. The fuel design is the Combustion Engineering System $8016 \times 16$ rod array fuel assembly.

2. The plant production capacity is $480 \mathrm{t} \mathrm{HM} /$ year with the capability for simultaneous production of three enrichments.

3. The plant factor is 240 effective full-production days per year.

4. Plant design capacity:

Overal1

$730 \mathrm{t} \mathrm{HM} /$ year

about 5 fuel assemblies/d

Each line of three

$243 \mathrm{t} \mathrm{HM} /$ year

$0.67 \mathrm{t} \mathrm{HM} / \mathrm{d}$

369 fuel rods/d

1.6 fuel assemblies/d

5. Process design capacities are based on the line design capacities and the scrap and sample losses defined in Sect. 9.4.4.

6. The facilities are designed to discharge no liquid waste other than treated sanitary sewage.

7. All process buildings and critical auxiliary support are designed and constructed in accordance with current United States Nuclear Regulatory Commission licensing requirements. Shielding is provided to limit dose rates to operating and maintenance personnel to 0.25 millirem/h.

\subsubsection{Estimates of Surge Storage Requirements, Scrap Production Rates, and Processing Rates for Functional Steps}

Given the plant design assumptions defined in Sect.9.4.3, further commercial plant characteristics were derived.

To achieve the annual production rates, an analysis of the plant surge storage requirements and normal inventory was made, and the results of this analysis are given in Table 9.20.

Based on current technology and assuming reasonable extrapolations for commercial-scale developments, a preliminary estimate was made of the daily mass flows of heavy metal through the fabrication plant and the average production rate of heavy metal scrap materials from the various functional activities. These are presented in Table 9.21. 
Table 9.20. Sphere-Pac Fabrication Plant Surge Storage Requirements and Normal Inventory [NASAP Case 1.5, PWR-U-Pu]

\begin{tabular}{|c|c|c|c|c|c|}
\hline \multirow{2}{*}{ Process Step } & \multirow{2}{*}{ Material } & \multicolumn{2}{|c|}{$\begin{array}{l}\text { Storage } \\
\text { Interval, d }\end{array}$} & \multicolumn{2}{|c|}{ Normal Inventory, $\mathrm{kg} \mathrm{HM}$} \\
\hline & & Norma1 & Maximum & $(\mathrm{Pu}, \mathrm{U}) \mathrm{O}_{2}{ }^{a}$ & $\mathrm{UO}_{2}$ Fines \\
\hline Feed storage & $\begin{array}{l}\text { Dried spheres } \\
\text { Sintered spheres }\end{array}$ & $\begin{array}{l}30 \\
30\end{array}$ & $\begin{array}{l}60 \\
60\end{array}$ & 50,000 & 13,000 \\
\hline Interim storage & $\begin{array}{l}\text { Dried spheres } \\
\text { Sintered spheres }\end{array}$ & $\begin{array}{l}1 \\
1\end{array}$ & $\begin{array}{l}2 \\
2\end{array}$ & 1,660 & 440 \\
\hline Furnace & $\begin{array}{l}\text { Dried to sintered } \\
\text { spheres }\end{array}$ & 1.2 & 2.4 & 2,000 & \\
\hline Post furnace & Sintered spheres & 0.5 & 1 & 830 & \\
\hline Interim storage & Sintered spheres & 0.36 & 0.72 & 600 & \\
\hline Main storage & $\begin{array}{l}\text { Sintered spheres } \\
\text { Sintered spheres }\end{array}$ & $\begin{array}{l}1.2 \\
1.5\end{array}$ & $\begin{array}{l}2.4 \\
2.9\end{array}$ & 2,100 & 660 \\
\hline $\begin{array}{l}\text { Loading, inspection } \\
\text { welding }\end{array}$ & Sintered spheres & 0.12 & 0.24 & 210 & 50 \\
\hline $\begin{array}{l}\text { Loaded, not inspected } \\
\text { rods }\end{array}$ & $\begin{array}{l}\text { Sintered spheres } \\
\text { in rods }\end{array}$ & 5 & 5 & 8,300 & 2,070 \\
\hline Rework and scrap & Sintered spheres & 2 & 5 & 410 & 75 \\
\hline Completed fuel rods & $\begin{array}{l}\text { Sintered spheres } \\
\text { in rods }\end{array}$ & 5 & 5 & 8,000 & 2,000 \\
\hline Assembly & $\begin{array}{l}\text { Rods in completed } \\
\text { assemblies }\end{array}$ & 15 & 30 & 24,000 & 6,000 \\
\hline
\end{tabular}

\footnotetext{
$a_{3.1 \% \text { nominal fissile plutonium content. }}$
} 
Table 9.21. Heavy Metal Mass Flows and Average Scrap Production for a Sphere-Pac Fuel Fabrication Plant [NASAP Case 1.5 PWR U - Pu]

\begin{tabular}{|c|c|c|c|c|c|c|}
\hline \multirow{3}{*}{ Processing Step } & \multicolumn{6}{|c|}{ Mass Flow, $\mathrm{kg} \mathrm{HM} / \mathrm{d}$} \\
\hline & \multicolumn{2}{|c|}{ Daily Throughput } & \multicolumn{2}{|c|}{ Clean Scrap $b$} & \multicolumn{2}{|c|}{ Reject Scrap ${ }^{e}$} \\
\hline & $(\mathrm{Pu}, \mathrm{U}) \mathrm{O}_{2}{ }^{\alpha}$ & $\mathrm{UO}_{2}$ Fines & $(\mathrm{Pu}, \mathrm{U}) \mathrm{O}_{2} a$ & $\mathrm{UO}_{2}$ Fines & $(\mathrm{Pu}, \mathrm{U}) \mathrm{O}_{2}{ }^{\alpha}$ & $\mathrm{UO}_{2}$ Fines \\
\hline Receiving and storage & $1662 \cdot 3$ & $437.8^{d}$ & & & & \\
\hline Sampling and batch loading & 1660.6 & & & & 1.7 & \\
\hline Weighing and sampling & & 437.4 & & & & 0.4 \\
\hline Calcining and sintering & 1659.8 & & & & 0.8 & \\
\hline Sphere upgrading & $1753.1^{e}$ & & & & 49.8 & \\
\hline Sphere sampling & 1749.6 & & & & 3.5 & \\
\hline Sphere storage & 1749.6 & 437.4 & & & & \\
\hline Fuel rod loading & 1749.6 & 437.4 & & & & \\
\hline Fuel rod scanning & 1662.1 & 415.5 & 84.0 & 21.0 & 3.5 & 0.9 \\
\hline Top component insertion & 1658.4 & 414.6 & 3.3 & 0.8 & 0.3 & 0.1 \\
\hline Rod welding and $x$ ray & 1658.4 & 414.6 & $f$ & $f$ & $f$ & $f$ \\
\hline Leak detection & 1658.4 & 414.6 & $f$ & $f$ & $f$ & $f$ \\
\hline Rod assay & 1625.3 & 406.3 & 31.5 & 7.9 & 1.7 & 0.4 \\
\hline Final rod inspection & 1608.4 & 402.1 & 16.3 & 4.1 & 0.7 & 0.2 \\
\hline Assembly inspection & 1600 & 400 & 8.0 & 2.0 & 0.3 & $\underline{0.1}$ \\
\hline Total & & & 143.1 & 35.8 & 62.3 & 2.1 \\
\hline
\end{tabular}

$a_{3.1 \%}$ nominal fissile plutonium content.

b Internally recycled.

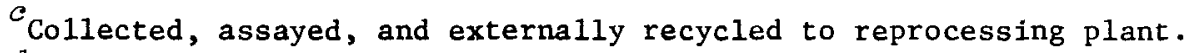

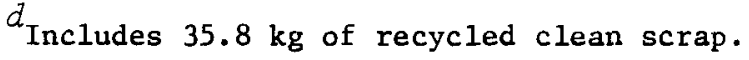

$e^{e}$ Includes $143.1 \mathrm{~kg}$ of recycled clean scrap.

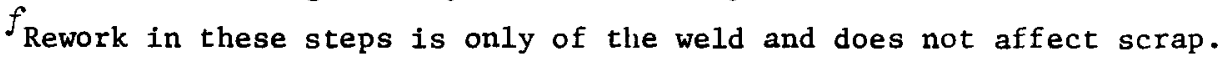


Given the above information, a preliminary evaluation of the processing rates for each functional step within the main fuel fabrication processes was made. The results of this analysis are summarized in Table 9.22.

\subsubsection{Analysis of Functional Technology Status, Research and Development Requirements, Cost, and Schedule}

The status and requirements are the same as those for the reference case given in Sect. 8 of this report and summarized in Table 9.23. A cost savings of approximately $5 \%$ may be possible because of the lack of spike radioactivity and its effects on maintenance details for the equipment, but no reduction in schedule is anticipated.

\subsubsection{Preliminary Cost Estimate for Construction and Operation of a Commercial-Scale Plant}

The cost components that were estimated include capital costs for the facility and equipment, fuel assembly hardware costs, material and supply costs, and operating costs.1-3

Facility capital cost estimates were based on an analysis of the functional flow diagram for the process to indicate space requirements for each functional area and for each support area. Equipment requirements were identified, and costs associated with the equipment were estimated. Fuel assembly hardware requirements were based on the reference fuel assembly design parameters identified in Table 9.1. Estimates of the costs of the hardware items were obtained. Material and supply requirements were identified from the sphere-pac process description, and estimates of the costs of materials and supplies were obtained. Operating cost estimates included consideration of personne1, overhead, genera1 and administrative expenses, and costs of utilities.

The facility was assumed to operate as a toll processing facility. That is, the operator fabricates customer-supplied fuel feed materials into finished fuel assemblies, and thus costs of plutonium and uranium 
Table 9.22. Equipment Requirements for Functional Areas [NASAP Case 1.5 PWR U-Pu]

\begin{tabular}{|c|c|c|c|c|c|}
\hline & Functional Area & Unit Production & $\begin{array}{l}\text { Plant Design } \\
\text { Requirement } \\
\text { (Nominal) }\end{array}$ & $\begin{array}{l}\text { Required } \\
\text { Number } \\
\text { of } \\
\text { Units }\end{array}$ & $\begin{array}{l}\text { Recommended } \\
\text { Number } \\
\text { of } \\
\text { Units }\end{array}$ \\
\hline 1.0 & $\begin{array}{l}\text { Recelving } \\
(\mathrm{Pu}, \mathrm{U}) \mathrm{O}_{2} \text { (10 containers/carrier) } \\
\mathrm{UO}_{2} \text { fines } \\
1.1 \text { Sampling }\end{array}$ & $\begin{array}{l}1600 \mathrm{~kg} / \mathrm{d} \\
\text { Unl } 1 \mathrm{~m} 1 \mathrm{ted} \\
\mathrm{NA}^{C} \text {; done at reprocessing } \\
\text { plant }\end{array}$ & $\begin{array}{l}1660 \mathrm{~kg} / \mathrm{d} \\
440 \mathrm{~kg} / \mathrm{d}\end{array}$ & $\begin{array}{l}2 \\
1\end{array}$ & $\begin{array}{l}2 \\
1\end{array}$ \\
\hline & $\begin{array}{l}1.2 \text { Weighing } \\
1.3 \text { Storage (80 kg HM/container) } \\
1.4 \text { We1ghing } \\
1.5 \text { VO } 2 \text { fines sampling } \\
1.6 \text { Storage }(200 \mathrm{~kg} \mathrm{HM} / \text { container })\end{array}$ & $\begin{array}{l}48 \text { contalners } / \mathrm{d} \\
\text { NA } \\
48 \text { containers } / \mathrm{d} \\
4800 \mathrm{~kg} / \mathrm{d} \\
\text { NA }\end{array}$ & $\begin{array}{l}21 \text { containers/d } \\
60 \mathrm{~d} \text { supply } \\
3 \text { containers/d } \\
440 \mathrm{~kg} / \mathrm{d} \\
60 \mathrm{~d} \text { supply }\end{array}$ & $\begin{array}{l}1 \\
1247 \\
1 \\
1 \\
131\end{array}$ & $\begin{array}{l}2 \\
1300 \\
1 \\
1 \\
140\end{array}$ \\
\hline 2.0 & $\begin{array}{l}\text { Fuel production (sphere processing) } \\
2.1 \text { Sampling } \\
2.2 \text { Calcining and sintering } \\
2.3 \text { Microsphere inspection } \\
2.4 \text { Interim storage }\end{array}$ & $\begin{array}{l}3840 \mathrm{~kg} / \mathrm{d} \\
240 \mathrm{~kg} / \mathrm{d} \\
20 \mathrm{~kg} / \mathrm{h} \\
250 \mathrm{~kg}\end{array}$ & $\begin{array}{l}1660 \mathrm{~kg} / \mathrm{d} \\
1660 \mathrm{~kg} / \mathrm{d} \\
75 \mathrm{~kg} / \mathrm{h} \\
1750 \mathrm{~kg}\end{array}$ & $\begin{array}{l}1 \\
8 \\
6 \\
8\end{array}$ & $\begin{array}{ll}1, & 3 \\
3, & 9 \\
2, & 6 \\
3, & 9\end{array}$ \\
\hline 3.0 & $\begin{array}{l}\text { Fuel rod fabrication } \\
3.1 \text { Sintered sphere storage } \\
3.2 \text { Sintered fertile storage } \\
3.3 \text { Sphere dispensing } \\
3.4 \text { Sphere-pac loading } \\
3.5 \text { Density inspection } \\
3.6 \text { Axial blanket (pellet) loading } \\
3.7 \text { Cleaning } \\
3.8 \text { Plenum hardware and top end } \\
3.9 \text { plugging } \\
3.10 \text { Rod assay } \\
3.11 \text { Rod inspection } \\
3.12 \text { Rod rework }\end{array}$ & $\begin{array}{l}\text { NA } \\
\text { NA } \\
35 \mathrm{~kg} / \mathrm{h} \\
4 \mathrm{rods} / \mathrm{h} \\
6 \mathrm{rods} / \mathrm{h} \\
\mathrm{NA} \\
24 \mathrm{rods} / \mathrm{h} \\
12 \mathrm{rods} / \mathrm{h} \\
12 \mathrm{rods} / \mathrm{h} \\
70 \mathrm{rods} / \mathrm{h} \\
40 \mathrm{rods} / \mathrm{h} \\
36 \mathrm{rods} / \mathrm{d}\end{array}$ & $\begin{array}{l}2 \mathrm{~d} \text { supply } \\
2 \mathrm{~d} \text { supply } \\
92 \mathrm{~kg} / \mathrm{h} \\
51 \mathrm{rods} / \mathrm{h} \\
51 \mathrm{rods} / \mathrm{h} \\
\mathrm{NAE} \\
48 \mathrm{rods} / \mathrm{h} \\
48 \mathrm{rods} / \mathrm{h} \\
48 \mathrm{rods} / \mathrm{h} \\
48 \mathrm{rods} / \mathrm{h} \\
47 \mathrm{rods} / \mathrm{h} \\
58 \mathrm{rads} / \mathrm{d}\end{array}$ & $\begin{array}{l}18 \\
4 \\
3 \\
14 \\
10 \\
\text { NA } \\
2 \\
4\end{array}$ & $\begin{array}{ll}8, & 24 \\
2, & 6 \\
1, & 3 \\
6, & 18 \\
4, & 12 \\
\text { NA } & \\
2, & 6 \\
2, & 6 \\
2, & 6 \\
1 & \\
2 & \\
1, & 3\end{array}$ \\
\hline 4.0 & $\begin{array}{l}\text { Fue1 assembly fabrication } \\
4.1 \text { Fuel rod storage } \\
4.2 \text { Fue1 assembly fabrication } \\
4.3 \text { Inspection } \\
4.4 \text { Rework }\end{array}$ & $\begin{array}{l}\text { NA } \\
3 \text { assemblies/d } \\
6 \text { assemb } 1 \text { es } / d \\
1 \text { assembly/d }\end{array}$ & $\begin{array}{l}5 \text { d production } \\
5 \text { assemblies/d } \\
5 \text { assemblyea/d } \\
0.02 \text { assembly/d }\end{array}$ & $\begin{array}{l}5556 \text { rods } \\
2 \\
1 \\
\mathrm{NR}^{d}\end{array}$ & $\begin{array}{l}6000 \text { rods } \\
2 \\
1 \\
\text { NR }\end{array}$ \\
\hline & Packaged fuel assembly storage & NA & 30 d production & 141 & 150 \\
\hline
\end{tabular}

a Recommended units include consideration of spare capacity for operational reliability.

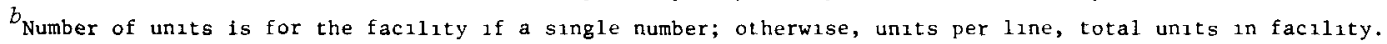

$c_{\mathrm{NA}}$ : not applicable.

$d_{\mathrm{NR}}$ : not required. Use assembly equipment as avallable. 
Table 9.23. Research and Development Cost Estimates for Sphere-Pac Fabrication (NASAP Case PWR U-Pu)

\begin{tabular}{|c|c|c|c|c|}
\hline & R\&D Categories & Current Status ${ }^{a}$ & $\begin{array}{c}\text { R\&D Cost Estimates } \\
\text { (Mil1ions of } \\
1978 \text { \$) }\end{array}$ & $\begin{array}{l}\text { Years to } \\
\text { Complete }\end{array}$ \\
\hline 1.0 & Program management & Not applicable & 8 & 8 \\
\hline 2.0 & Design studies & $P-$ cold engineering & 25 & 8 \\
\hline 3.0 & Receiving and storage & $P$ - cold engineering & 3 & 5 \\
\hline 4.0 & Fuel production & $P-\operatorname{cold}$ engineering & 25 & 8 \\
\hline 5.0 & Fuel rod fabrication & $\mathrm{N}-$ cold engineering & 46 & 7 \\
\hline 6.0 & Fuel element assembly & $\mathrm{N}-$ cold engineering & 15 & 7 \\
\hline 7.0 & Scrap recovery & $\mathrm{N}-$ cold engineering & 2 & 5 \\
\hline 8.0 & Waste treatment & $b$ & $b$ & $b$ \\
\hline 9.0 & Plant control systems & $\mathrm{N}-$ cold prototype & 5 & 8 \\
\hline 10.0 & Maintenance & $\mathrm{N}-$ cold engineering & 5 & 8 \\
\hline 11.0 & $\begin{array}{l}\text { Safeguards and account- } \\
\text { ability adaptation }\end{array}$ & $P-\operatorname{cold}$ engineering & 6 & 6 \\
\hline & Subtotal & & 140 & \\
\hline \multicolumn{5}{|c|}{ Special Facilities } \\
\hline \multicolumn{2}{|c|}{ Hot tests } & & 10 & \\
\hline \multicolumn{2}{|c|}{ Cold prototype } & & 25 & \\
\hline \multicolumn{2}{|r|}{ Total } & & $175^{d}$ & \\
\hline \multicolumn{2}{|r|}{ Range } & & $165-210$ & \\
\hline $\begin{array}{l}\mathrm{N}= \\
\text { app1 }\end{array}$ & $\begin{array}{l}{ }^{a} \text { Status stage with qualit } \\
\text { leeded. } \\
b_{\text {To be supplied by others }} \\
c_{\text {Assumes basic technology }} \\
\text { cations testing, systems } \\
d_{\text {The estimate does not in }} \\
\text { on) or the capital costs }\end{array}$ & $\begin{array}{l}\text { ive modifiers; } \mathrm{C}=\mathrm{co} \\
\text { s developed under oss } \\
\text { tegraton, and testing } \\
\text { ude costs for fuel qu } \\
\text { a pilot plant estima }\end{array}$ & $\begin{array}{l}\text { lete, } P=\text { in progr } \\
\text { estimate presented } \\
\text { ification tests }(a \\
\text { d at } \$ 140 \text { million. }\end{array}$ & $\begin{array}{l}s \text {, and } \\
\text { for } \\
\text { ut } \$ 20\end{array}$ \\
\hline
\end{tabular}


were not included in the cost estimates. The hardware and material costs do include the costs associated with the production of the depleted or natural $\mathrm{UO}_{2}$ spheres.

Unit costs for fabrication of fuel assemblies are determined by an economic analysis of the basic capital, hardware and material, and operating cost estimates. Basically, the economic analysis provides for the owner of the fuel fabrication facility to recover all capital, operating, and finance charges plus a return on investment, if appropriate, over the life of the plant.

In order to provide a range of prices (i.e., costs to a customer), economic analyses were based on government financing, financing appropriate for a conventional-risk (typical) industry, and financing appropriate for a high-risk industry. 2 The estimated costs, costs derived from the economic analysis, and the unit costs based on the three different financing methods are summarized in Table 9.24. As may be observed from the table, the price for fabrication of unspiked $(\mathrm{Pu}, \mathrm{U}) \mathrm{O}_{2}$ fuel is expected to be in the range from $\$ 280$ to $\$ 680 / \mathrm{kg}$ depending on the financing technique that is employed. The recommended cost for comparison with other fuel cycles and methods of fabrication is the typical industry cost of $\$ 460 / \mathrm{kg}$. 
Table 9.24. Summary of Costs for Fabrication of Sphere-Pac PWR Fuel in a 2-t HM/d Facility (NASAP Case 1.5 PWR U-Pu)

\begin{tabular}{|c|c|c|c|c|c|c|c|c|c|}
\hline \multirow[b]{2}{*}{$\begin{array}{c}\text { Economic } \\
\text { Set }^{a}\end{array}$} & \multicolumn{4}{|c|}{ Estimated Costs, $\$$ million } & \multicolumn{4}{|c|}{ Derived Costs, $\$$ million } & \multirow[b]{2}{*}{$\begin{array}{c}\text { Unit } \\
\text { Cost } \\
(\$ / \mathrm{kg})\end{array}$} \\
\hline & Facility & Equipment & $\begin{array}{c}\text { Annual } \\
\text { Hardware } \\
\text { Plus } \\
\text { Materials }\end{array}$ & $\begin{array}{c}\text { Annual } \\
\text { Operating }\end{array}$ & $\begin{array}{c}\text { Owner's } \\
\text { Cost } \\
\text { During } \\
\text { Construction }\end{array}$ & $\begin{array}{c}\text { Charge on } \\
\text { Direct Capital } \\
\text { During } \\
\text { Construction }\end{array}$ & $\begin{array}{c}\text { Annual } \\
\text { Equipment } \\
\text { Replacement } \\
\text { Cost }\end{array}$ & $\begin{array}{c}\text { Annual } \\
\text { Payment to } \\
\text { Decommissioning } \\
\text { Fund }\end{array}$ & \\
\hline A & 250 & 200 & 30 & 25 & 36 & 120 & 10 & 1.2 & 280 \\
\hline B & 250 & 200 & 30 & 26 & 37 & 180 & 10 & 1.2 & 460 \\
\hline C & 250 & 200 & 30 & 26 & 38 & 180 & 10 & 1.2 & 680 \\
\hline
\end{tabular}

$a_{\mathrm{A}}=$ Government financing; $\mathrm{B}=$ Typical industrial financing; $\mathrm{C}=$ High-risk industrial financing. 
9.5 NASAP CASE 2.1 - HWR $\left({ }^{235} \mathrm{U}, \mathrm{U}\right) \mathrm{O}_{2}$ FABRICATION [HWR LEU(5)-OT]

\subsubsection{Fue1 Cyc1e Description}

This reactor-fuel cycle combination is a CANDU-type HWR using 1. $2 \%$-enriched uranium oxide pellet fuel optimized for a once-through cycle. Spent fuel will be stored at the reactor site or elsewhere. Ultimately, the spent fuel will be sent to a geologic spent fuel repository.

Since this cycle is defined as a once-through cycle, only fuel fabrication processes were assessed. It is apparent that current pellet processing could be adapted to this cycle with plant and fuel pellet design modifications. The process requires a contact-operated and contactmaintained ( $\mathrm{CO} / \mathrm{CM})$ plant.

The sphere-pac process was assessed for this case for two reasons. First, it addresses the applicability of the process to heavy water reactor fuel element types. Second, the cycle requires much higher burnup than that experienced in current CANDU reactors that use natural uranium as fuel. As indicated for the extended-burnup fuels in a light-water reactor (Case 1.2, Sect. 9.1) the sphere-pac process may be preferred to reduce fuel-cladding mechanical interaction.

\subsubsection{Applicability to Current Fuel Element Design}

There are a number of existing heavy water reactor fuel element designs. For this analysis, the representative design chosen for this case is presented in Table 9.25.

The key considerations for sphere-pac applicability are the cladding inside diameter measurements and the required fuel smear density. The cladding ID of $12,270 \mu \mathrm{m}$ in the reference design is suitable for the sphere-pac process. Since the design smear density of $91 \%$ exceeds that achieved with experimental blended (three particle size) sphere-pac beds, the process is marginally applicable. However a lower smear density may be required to achieve the higher burnup specified for this case. 
Table 9.25. Summary of CANDU 37-Pin Fuel Bundle Parameters [NASAP Case 2.1 - HWR LEU(5)-OT]

\section{Reactor Characteristics}

Reactor power Fuel assemblies/core Reload cycle

Component Characteristics

Fue1 cladding

End plugs

Top

Bottom

Bearing pads

Interelement spacers

End support plates
1000 MWe (net)

7204

Continuous on-power refueling (about 40\%/year)

Number per Mass $(\mathrm{kg})$ per

Material Fuel Assembly Fuel Assemb1y

Zircaloy -4

37

1.954

Zircaloy -4

Zircaloy -4

Zircaloy -4

Zircaloy -4

Zircaloy -4
0.104

0.104

37

$54)$

$156\}$

0.108

Fuel Rod Characteristics

Fuel cladding outside diameter

Fuel cladding inside diameter

Fuel rod length

Fuel column height

Fuel smear density

Pellet diameter

Pellet length

Fuel Assembly Characteristics

Dimensions

Length

Diameter

Mass of structural components

Heavy metal content (mean) -
$13.1 \mathrm{~mm}$ (0.515 in.)

$12.3 \mathrm{~mm}$ (0.483 in.)

$483 \mathrm{~mm}$ (19.0 in.)

$480 \mathrm{~mm}$ (18.9 in.)

ง91\% T.D.

$12.1 \mathrm{~mm}$ (0.478 in.)

$16.0 \mathrm{~mm}$ (0.630 in.)
$495 \mathrm{~mm}(1.62 \mathrm{ft})$

$100 \mathrm{~mm}$ (3.94 in.)

$2.27 \mathrm{~kg}$

$18.7 \mathrm{~kg}$ 
9.5.3 Definition of Plant Production Requirements and Design Capacity

For this fuel cycle, the plant assumptions are as follows.

1. The fuel design is the current heavy water reactor bundle (37 pin) of the CANDU design.

2. The plant production capacity is $520 \mathrm{t} \mathrm{HM} /$ year with the capability for simultaneous production of three enrichments.

3. The plant factor is 260 effective full-production days per year.

4. Plant design capacity:

Overall

$730 \mathrm{t} \mathrm{HM} /$ year

about 107 fuel assemblies/d

Each line of three

$243 \mathrm{t} \mathrm{HM} /$ year

$0.67 \mathrm{t} \mathrm{HM} / \mathrm{d}$

1319 fuel rods/d

35.7 fuel assemblies/d

5. Process design capacities are based on the line design capacities and the scrap and sample losses defined in Sect. 9.5.4.

6. The facilities are designed to discharge no liquid waste other than treated sanitary sewage.

7. All process buildings and critical auxiliary support are designed and constructed in accordance with current United States Nuclear Regulatory Commission licensing requirements. Shielding is provided to limit dose rates to operating and maintenance personnel to $0.25 \mathrm{millirem} / \mathrm{h}$.

\subsubsection{Estimates of Surge Storage Requirements, Scrap Production Rates, and Processing Rates for Functiona1 Steps}

Given the plant design assumptions defined in Sect.9.5.2, further commercial plant characteristics were derived.

To achieve the annual production rates, an analysis of the plant surge storage requirements and normal inventory was made, and the results of this analysis are given in Table 9.26.

Based on current technology and assuming reasonable extrapolations for commercial-scale developments, a preliminary estimate was made of the 
Table 9.26. Sphere-Pac Fabrication Plant Surge Storage Requirements and Normal Inventory [NASAP Case 2.1 HWR LEU(5) - OT]

\begin{tabular}{|c|c|c|c|c|c|}
\hline \multirow{2}{*}{ Process Step } & \multirow{2}{*}{ Material } & \multicolumn{2}{|c|}{$\begin{array}{l}\text { Storage } \\
\text { Interval, d }\end{array}$} & \multicolumn{2}{|c|}{ Normal Inventory, $\mathrm{kg} \mathrm{HM}$} \\
\hline & & Norma1 & Maximum & $\left({ }^{3}{ }^{5} \mathrm{U}, \mathrm{U}\right) \mathrm{O}_{2} a$ & $\left({ }^{235} \mathrm{U}, \mathrm{U}\right) \mathrm{O}_{2}$ Fines \\
\hline Feed storage & $\begin{array}{l}\text { Dried spheres } \\
\text { Sintered spheres }\end{array}$ & $\begin{array}{l}30 \\
30\end{array}$ & $\begin{array}{l}60 \\
60\end{array}$ & 50,000 & 13,000 \\
\hline Interim storage & $\begin{array}{l}\text { Dried spheres } \\
\text { Sintered spheres }\end{array}$ & $\begin{array}{l}1 \\
1\end{array}$ & $\begin{array}{l}2 \\
2\end{array}$ & 1,660 & 440 \\
\hline Furnace & $\begin{array}{l}\text { Dried to sintered } \\
\text { spheres }\end{array}$ & 1.2 & 2.4 & 2,000 & \\
\hline Post furnace & Sintered spheres & 0.5 & 1 & 830 & \\
\hline Interim storage & Sintered spheres & 0.36 & 0.72 & 600 & \\
\hline Main storage & $\begin{array}{l}\text { Sintered spheres } \\
\text { Sintered spheres }\end{array}$ & $\begin{array}{l}1.2 \\
1.5\end{array}$ & $\begin{array}{l}2.4 \\
2.9\end{array}$ & 2,100 & 660 \\
\hline $\begin{array}{l}\text { Loading, inspection } \\
\text { welding }\end{array}$ & Sintered spheres & 0.12 & 0.24 & 210 & 50 \\
\hline $\begin{array}{l}\text { Loaded, not inspected } \\
\text { rods }\end{array}$ & $\begin{array}{l}\text { Sintered spheres } \\
\text { in rods }\end{array}$ & 5 & 5 & 8,300 & 2,070 \\
\hline Rework and scrap & Sintered spheres & 2 & 5 & 410 & 75 \\
\hline Completed fuel rods & $\begin{array}{l}\text { Sintered spheres } \\
\text { in rods }\end{array}$ & 5 & 5 & 8,000 & 2,000 \\
\hline As sembly & $\begin{array}{l}\text { Rods in completed } \\
\text { assemblies }\end{array}$ & 15 & 30 & 24,000 & 6,000 \\
\hline
\end{tabular}

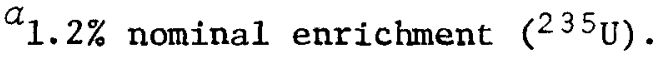


daily mass flows of heavy metal through the fabrication plant and the average production rate of heavy metal scrap materials from the various functional activities. These are presented in Table 9.27.

Given the above information, a preliminary evaluation of the processing rates for each functional step within the main fuel fabrication processes was made. The results of this analysis are summarized in

Table 9.28.

\subsubsection{Analysis of Functional Technology Status, Research and Development Requirements, Cost, and Schedule}

The technology status of this system is quite similar to that of the reference case discussed in Sect. 8. The current status and research and development needs are summarized in Table 9.29. Some significant differences in the process are worthy of note. Fuel rod fabrication is quite similar except for the relatively short length and therefore the significant increase in the number of rods that must be made to achieve an annual throughput of $520 \mathrm{t} \mathrm{HM}$.

Fuel element assembly is significantly different. The fuel rod spacing is defined by spacers placed on the outside of the cladding. The two end plates need to be welded to each fuel rod in an assembly. We have assumed an exchange of information with current Canadian manufacturers to reduce the development needs and costs in this area.

The CO/CM type plant will minimize the research and development requirements for special features associated with maintenance. However the value of the enriched uranium and United States licensing requirements will probably require modifications to current commercial practice, and an allowance has been made for this in the cost estimate.

\subsubsection{Preliminary Cost Estimate for Construction and Operation of a Commercia1-Scale Plant}

The cost components that were estimated include capital costs for the facility and equipment, fuel assembly hardware costs, material and supply 
Table 9.27. Heavy Metal Mass Flows and Average Scrap Production for a Sphere-Pac Fuel Fabrication Plant [NASAP Case 2.1 HWR LEU(5) - OT]

\begin{tabular}{|c|c|c|c|c|c|c|}
\hline \multirow{3}{*}{ Processing Step } & \multicolumn{6}{|c|}{ Mass Flow, $\mathrm{kg} \mathrm{HM} / \mathrm{d}$} \\
\hline & \multicolumn{2}{|c|}{ Daily Throughput } & \multicolumn{2}{|c|}{ Clean Scrap ${ }^{b}$} & \multicolumn{2}{|c|}{ Reject Scrap ${ }^{c}$} \\
\hline & $\left({ }^{235} \mathrm{U}, \mathrm{U}\right) \mathrm{O}_{2} a$ & $\left({ }^{3}{ }^{3} \mathrm{U}, \mathrm{U}\right) \mathrm{O}_{2}$ Fines $^{\alpha}$ & $\left({ }^{2}{ }^{5} \mathrm{U}, \mathrm{U}\right) \mathrm{O}_{2}{ }^{a}$ & $\left({ }^{35}{ }^{U}, U\right) O_{2}$ Fines $^{a}$ & $\left({ }^{235} \mathrm{U}, \mathrm{U}\right) \mathrm{O}_{2} a$ & $\left({ }^{235} \mathrm{U}, \mathrm{U}\right) \mathrm{O}_{2}$ Fines $^{a}$ \\
\hline Receiving and storage. & $1662 \cdot 3$ & $437.8^{d}$ & & & & \\
\hline Sampling and batch loading & 1660.6 & & & & 1.7 & \\
\hline Weighing and sampling & & 437.4 & & & & 0.4 \\
\hline Calcining and sintering & 1659.8 & & & & 0.8 & \\
\hline Sphere upgrading & $1753.1^{e}$ & & & & 49.8 & \\
\hline Sphere sampling & 1749.6 & & & & 3.5 & \\
\hline Sphere storage & 1749.6 & 437.4 & & & & \\
\hline Fue1 rod loading & 1749.6 & 437.4 & & & & \\
\hline Fue1 rod scanning & 1662.1 & 415.5 & 84.0 & 21.0 & 3.5 & 0.9 \\
\hline Top component insertion & 1658.4 & 414.6 & 3.3 & 0.8 & 0.3 & 0.1 \\
\hline Rod welding and $x$ ray & 1658.4 & 414.6 & $f$ & f & $f$ & $f$ \\
\hline Leak detection & 1658.4 & 414.6 & $f$ & $f$ & $f$ & $f$ \\
\hline Rod assay & 1625.3 & 406.3 & 31.5 & 7.9 & 1.7 & 0.4 \\
\hline Final rod inspection & 1608.4 & 402.1 & 16.3 & 4.1 & 0.7 & 0.2 \\
\hline Assembly inspection & 1600 & 400 & 8.0 & 2.0 & 0.3 & 0.1 \\
\hline Total & 200 & & 143.1 & 35.8 & 62.3 & 2.1 \\
\hline
\end{tabular}

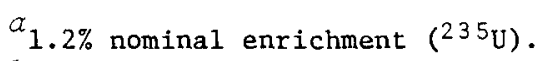

$b_{\text {Internally recycled. }}$

${ }^{c}$ Collected, assayed, and externally recycled to reprocessing plant.

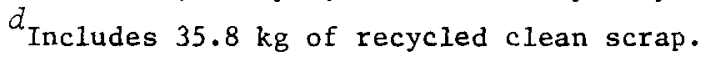

e Includes $143.1 \mathrm{~kg}$ of recycled clean scrap.

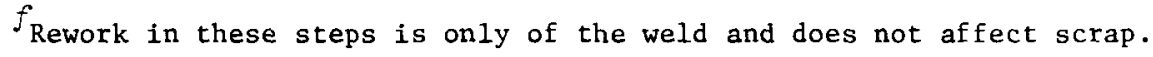


Table 9.28. Equipment Requirements for Functional Areas [NASAP Case 2.1 HWR LEU(5) - OT]

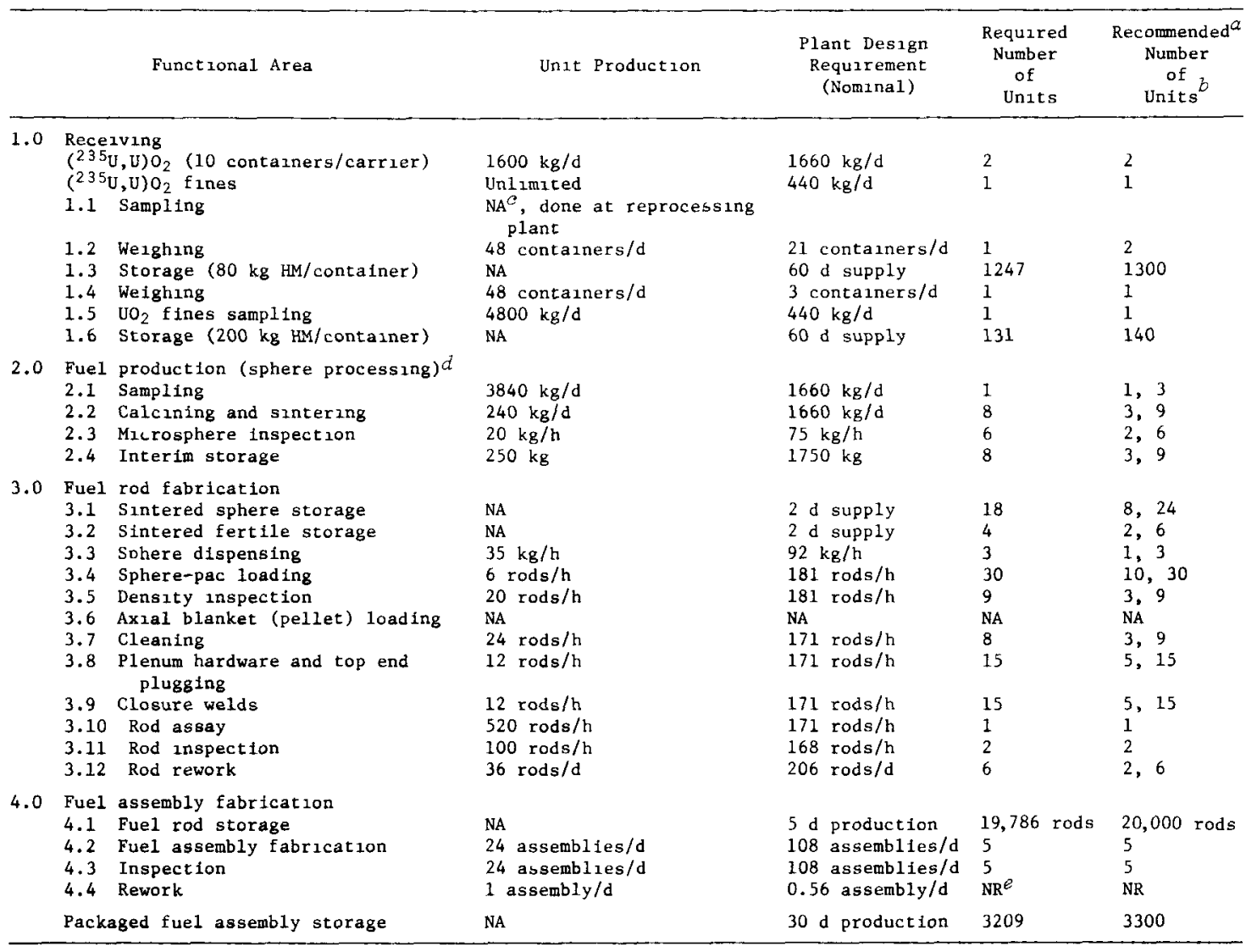

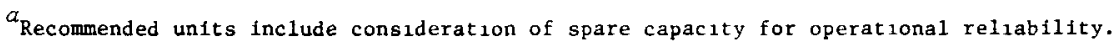

$b$ Number of units is for the facility if a single number, otherwise, units per line, total units in facility. $c_{\mathrm{NA}}$ : not applicable.

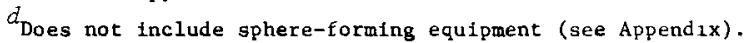

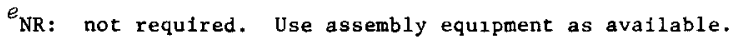


Table 9.29. Research and Development Cost Estimates for Sphere-Pac Fabrication [NASAP Case 2.1 HWR LEU(5)]

\begin{tabular}{|c|c|c|c|c|}
\hline & R\&D Categories & Current status ${ }^{a}$ & $\begin{array}{l}\text { R\&D Cost Estimates } \\
\text { (Millions of } \\
1978 \$)\end{array}$ & $\begin{array}{l}\text { Years to } \\
\text { Complete }\end{array}$ \\
\hline 1.0 & Program management & Not applicable & 5 & 5 \\
\hline 2.0 & Design studies & $\mathrm{N}-\operatorname{cold}$ prototype & 5 & 5 \\
\hline 3.0 & Receiving and storage & $P-$ cold engineering & 0 & \\
\hline 4.0 & Fuel production & $P$ - cold engineering & 19 & 5 \\
\hline 5.0 & Fuel rod fabrication & $P$ - cold engineering & 20 & 5 \\
\hline 6.0 & Fuel element assembly & C - commercial (Canada) & 0 & \\
\hline 7.0 & Scrap recovery & $\mathrm{C}-$ commercial & 0 & \\
\hline 8.0 & Waste treatment & $b$ & $b$ & $b$ \\
\hline 9.0 & Plant control systems & $N-\operatorname{cold}$ prototype & 5 & 5 \\
\hline 10.0 & Maintenance & $\mathrm{N}-$ cold prototype & 1 & 2 \\
\hline 11.0 & $\begin{array}{l}\text { Safeguards and account- } \\
\text { ability adaptation }{ }^{c}\end{array}$ & $P-\operatorname{cold}$ engineering & 4 & 2 \\
\hline & Subtota1 & & 59 & \\
\hline
\end{tabular}

Special Facilities

Hot tests

Cold prototype

Tota1

Range
Not required

10

$69^{d}$

$65-85$

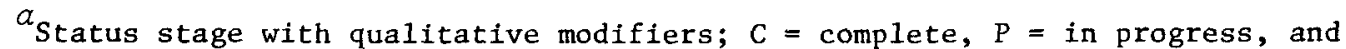
$\mathrm{N}=$ needed .

$b$ To be supplied by others.

${ }^{c}$ Assumes basic technology as developed under oss estimate presented is for applications testing, systems integraton, and testing.

$d_{\text {The estimate does not include the research and development costs for gel }}$ sphere forming (see Appendix) or fuel qualification tests (about $\$ 5$ million). 
costs, and operating costs.1-3 In making these estimates we utilized information from the generic case presented earlier for process steps through fuel rod loading and inspection. The fuel element assembly operations and balance of plant requirements were derived from a previous study based on the pellet process. ${ }^{2}$ These cost estimates include the $\mathrm{UO}_{2}$ sphere-forming operations. These operations require an addition to the plant beyond that shown in the reference case to receive $\mathrm{UF}_{6}$ and process it to dried spheres. These operations were included in the cost estinate.

Facility capital cost estimates were based on an analysis of the functional flow diagram for the process to indicate space requirements for each functional area and for each support area. Equipment requirements were identified, and costs associated with the equipment were estimated. Fuel assembly hardware requirements were based on the reference fuel assembly design parameters identified in Table 9.25. Estimates of the costs of the hardware items were obtained. Material and supply requirements were identified from the sphere-pac process description, and estimates of the costs of materials and supplies were obtained. Operating cost estimates included consideration of personnel, overhead, general and administrative expenses, and costs of utilities.

The facility was assumed to operate as a toll processing facility. That is, the operator fabricates customer-supplied fuel feed materials into finished fuel assemblies, and thus costs of uranium were not included in the cost estimates.

Unit costs for fabrication of fuel assemblies are determined by an economic analysis of the basic capital, hardware and material, and operating cost estimates. Basically, the economic analysis provides for the owner of the fuel fabrication facility to recover all capital, operating, and finance charges plus a return on investment, if appropriate, over the life of the plant.

In order to provide a range of prices (i.e., costs to a customer), economic analyses were based on government financing, financing appropriate for a conventional-risk (typica1) industry, and financing appropriate for a high-risk industry. 2 The estimated costs, costs derived from the economic analysis, and the unit costs based on the three 
different financing methods are summarized in Table 9.30. As may be observed from the table, the price for fabrication of $\left({ }^{235} \mathrm{U}, \mathrm{U}\right) \mathrm{O}_{2}$ fuel is expected to be in the range from $\$ 65$ to $\$ 110 / \mathrm{kg}$ depending on the financing technique that is employed. The recommended cost for comparison with other fuel cycles and methods of fabrication is the typical industry cost of $\$ 90 / \mathrm{kg}$. 
Table 9.30. Sumary of Costs for Fabrication of Sphere-Pac PWR Fuel in a 2-t HM/d Facility [NASAP Case 2.1 HWR $\left({ }^{235} \mathrm{U}, \mathrm{U}\right) \mathrm{O}_{2}$ Fabrication]

\begin{tabular}{|c|c|c|c|c|c|c|c|c|c|}
\hline \multirow[b]{2}{*}{$\begin{array}{c}\text { Economic } \\
\text { Set }^{a}\end{array}$} & \multicolumn{4}{|c|}{ Estimated Costs, $\$$ million } & \multicolumn{4}{|c|}{ Derived Costs, $\$$ million } & \multirow[b]{2}{*}{$\begin{array}{c}\text { Unit } \\
\text { Cost } \\
(\$ / \mathrm{kg})\end{array}$} \\
\hline & Facility & Equipment & $\begin{array}{c}\text { Annual } \\
\text { Hardware } \\
\text { Plus } \\
\text { Materials }\end{array}$ & $\begin{array}{c}\text { Annual } \\
\text { Operating }\end{array}$ & $\begin{array}{c}\text { Owner's } \\
\text { Cost } \\
\text { During } \\
\text { Construction }\end{array}$ & $\begin{array}{c}\text { Charge on } \\
\text { Direct Capital } \\
\text { During } \\
\text { Construction }\end{array}$ & $\begin{array}{c}\text { Annual } \\
\text { Equipment } \\
\text { Replacement } \\
\text { Cost }\end{array}$ & $\begin{array}{c}\text { Annual } \\
\text { Payment to } \\
\text { Decommissioning } \\
\text { Fund }\end{array}$ & \\
\hline$A$ & 20 & 34 & 12 & 11 & 16 & 17 & 1.7 & 0.5 & 65 \\
\hline B & 20 & 34 & 12 & 12 & 17 & 25 & 1.7 & 0.5 & 90 \\
\hline $\mathrm{c}$ & 20 & 34 & 12 & 12 & 17 & 25 & 1.7 & 0.5 & 110 \\
\hline
\end{tabular}

$a_{\mathrm{A}}=$ Government financing; $\mathrm{B}=$ Typical industrial financing; $\mathrm{c}=$ High-risk industrial financing. 
9.6 NASAP CASE 3.1.1 - LWBR MEU(5)-Th RECYCLE, PWR BACKFIT PREBREEDER

\subsubsection{Fuel Cycle Description}

The prebreeder would use duplex fuel of $15.6 \%$-enriched $235_{U}$ [U(5)] and thoria. The spent duplex fuel would first be reprocessed to recover the bred $233 \mathrm{U}$ from the thoria. The recovered $235_{\mathrm{U}}$ would be recycled to enrichment, the plutonium and bred $233_{\mathrm{U}}$ would be sent to a secure storage center, and the thorium would be sent to 10-year interim storage.

In this fuel cycle only fresh fuel is fabricated in a contactoperated and contact-maintained (CO/CM) facility.

\subsubsection{Applicability to Current Fuel Element Design}

Available information on the design for the fuel elements for this reactor are given in Table 9.31. The sphere-pac process is not applicable to this design because of the requirement for duplex loading of $\mathrm{ThO}_{2}$ and $\mathrm{UO}_{2}$. The annular arrangement of the two fuel components, $\mathrm{ThO}_{2}$ on the inside surrounded by $\mathrm{UO}_{2}$, would not be practical for sphere-pac loading. 
Table 9.31. Summary of DOE Division of Naval Reactors LWBR Fuel Module Parameters

[NASAP Case 3.1.1 - LWBR MEU(5)-Th, U(5) Recycle, PWR Backfit Prebreeder]

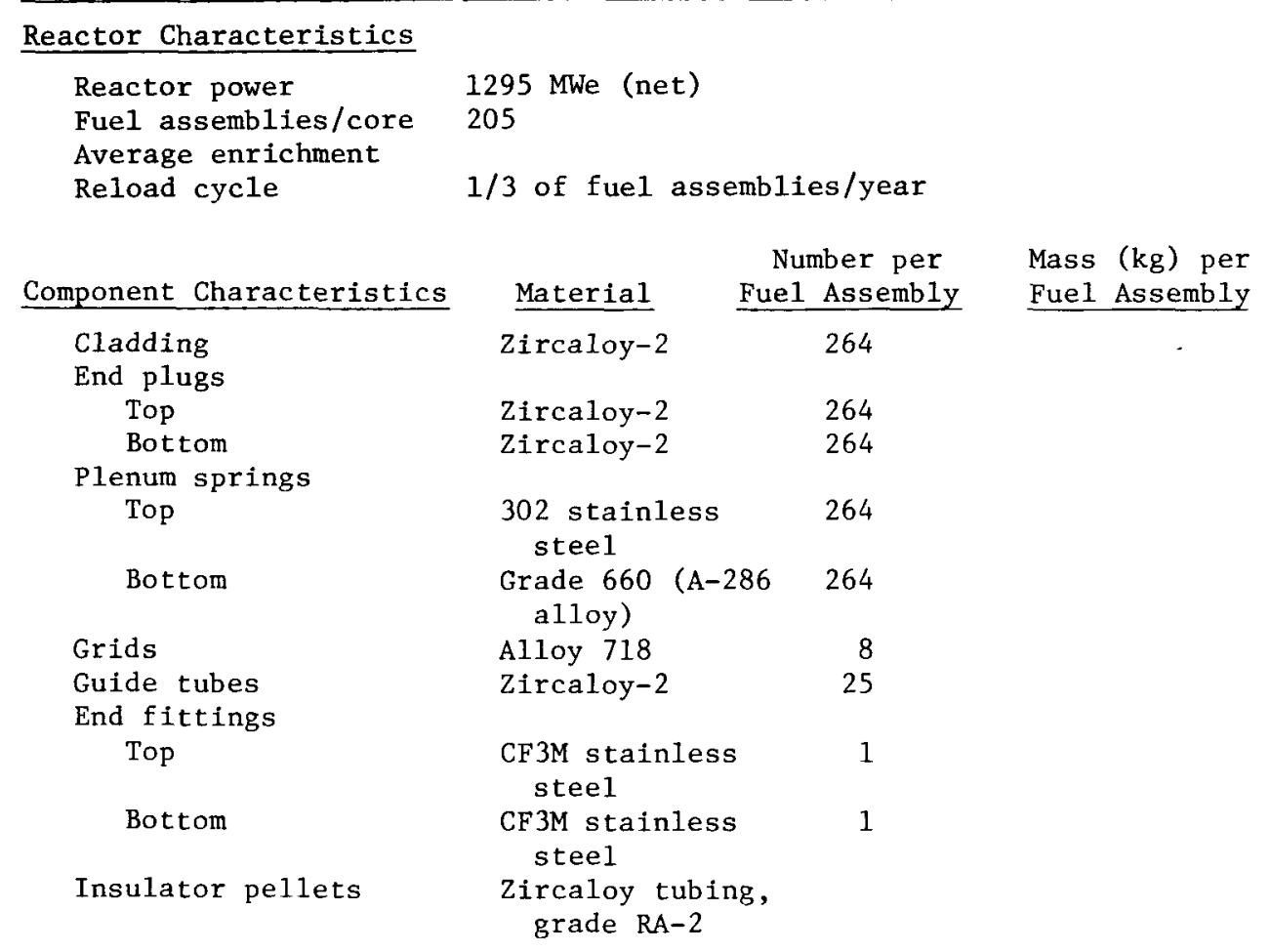

Fuel Rod Characteristics

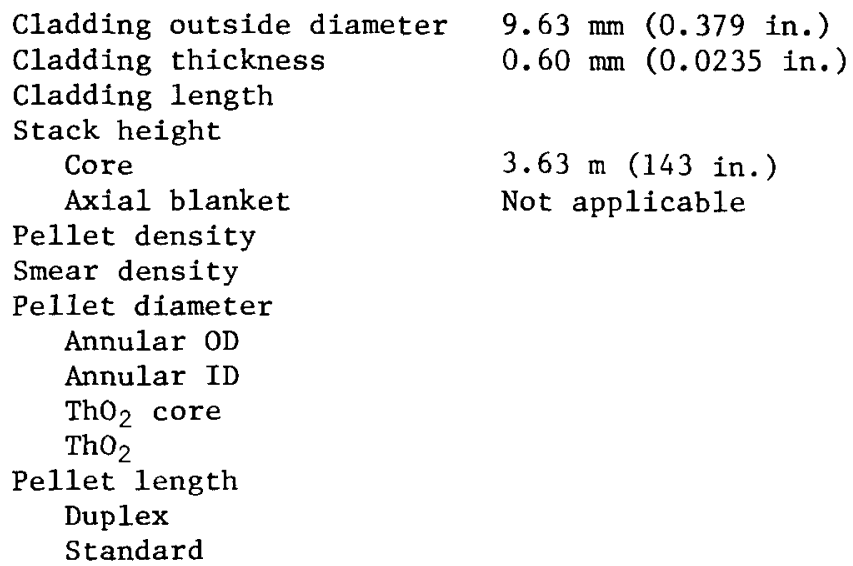

Fuel Assembly Characteristics

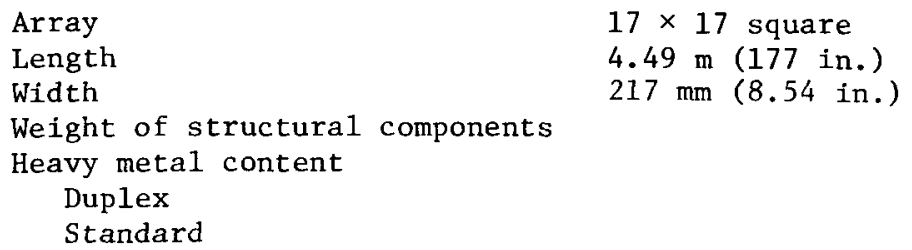


9.7 NASAP CASE 3.1.2 - LWBR HEU(3)-Th, RECYCLED U(3), ADVANCED BREEDER

\subsubsection{Fue1 Cycle Description}

The advanced breeder would use a large extrapolated PWR-type vessel modified for a tight lattice, hexagonal fuel bundle, and thoria control rods. The fuel would consist of a binary solid solution of highly enriched urania and thoria in the form of pellets. The spent fuel would be reprocessed to recover the $233 \mathrm{U}$ and thorium, which would be recycled to remote fuel fabrication.

In this fuel cycle all fuel would contain $232 \mathrm{U}$ and the high level of radioactivity associated with its decay products. Consequently a remotely operated and remotely maintained (RO/RM) facility would be required.

\subsubsection{Applicability to Current Fuel Element Design}

Available information on the proposed fuel element design for this reactor cycle is given in Table 9.32. Additional information suggests that the individual rods within the seed and blanket segments of the assembly would have varying lengths of $(\mathrm{U}, \mathrm{Th}) \mathrm{O}_{2}$ and $\mathrm{ThO}_{2}$. Although there is insufficient design detail to permit a complete applicability analysis, it appears as though the gel-sphere-pac process would be applicable. The key considerations for sphere-pac applicability are the cladding inside diameter measurements and the required fuel smear density. The cladding ID of $13,080 \mu \mathrm{m}$ in the reference design is suitable for the sphere-pac process. If the required smear density for the fuel does not exceed the $87 \%$ of theoretical density that is practical with the three-particle sphere-pac process, then the process is applicable.

\subsubsection{Definition of Plant Production Requirements and Design Capacity}

Plant production requirements cannot be defined until additional fuel element design data are avallable. 
Table 9.32. Summary of DOE Division of Naval Reactors

LWBR Fuel Module Parameters, Seed Assembly Portion

[NASAP Case 3.1.2 - LWBR HEU(3)-Th, Recycled U(3), Advanced Breeder]

Reactor Characteristics

Reactor power 1035 MWe (net)

Fuel assemblies $\quad 151$ seed/blanket modules

12 seed/blanket half modules

Average enrichment

Reload cycle

\begin{tabular}{lccc} 
Component Characteristics & Material & $\begin{array}{c}\text { Number per } \\
\text { Fuel Assembly }\end{array}$ & $\begin{array}{c}\text { Mass (kg) per } \\
\text { Fuel Assembly }\end{array}$ \\
\cline { 1 - 2 } Cladding & Zircaloy-4 & 288 & \\
End plugs & & & 288 \\
Top & Zircaloy-4 & 288 \\
$\quad$ Bottom & Zircaloy-4 & 288 \\
Plenum springs & Zircaloy-4 & \\
Grids & Zircaloy-4 & 100 \\
Guide tubes & & \\
End fittings & & 1 \\
Top & & 1
\end{tabular}

Fuel Rod Characteristics

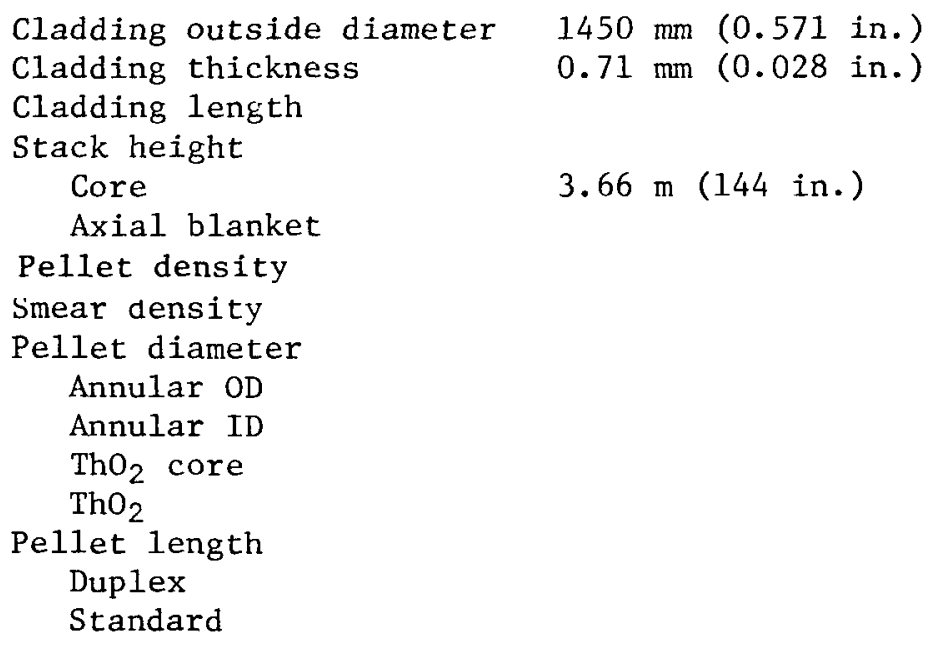

Fuel Assembly Characteristics

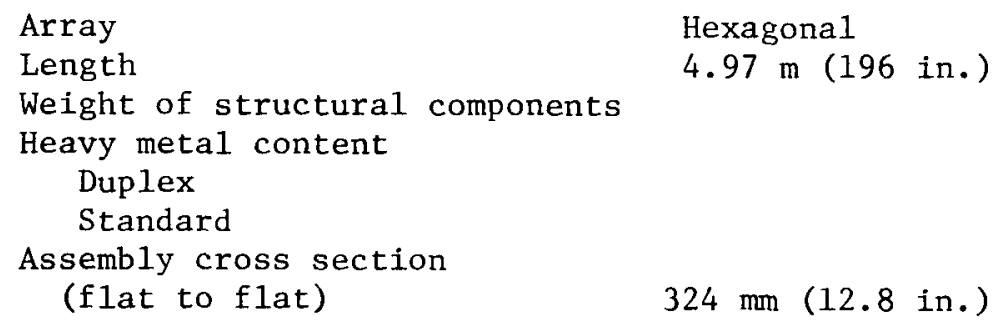

(flat to flat) $324 \mathrm{~mm}$ (12.8 in.)

Hexagonal

$4.97 \mathrm{~m}$ (196 in.) 
9.7.4 Estimates of Surge Storage Requirements, Scrap Production

Estimates cannot be determined until the plant has been defined.

9.7.5 Analysis of Functional Technology Status, Research and Development Requirements, Cost, and Schedule

The current technology status in terms of the fuel rod loading process should be essentially that for the reference case discussed in Sect. 8 of this report. Fuel element assembly processes would be similar to those for the reference case but would be complicated by the twosegment (seed and blanket) arrangement and the indicated variations in fuel rod contents with position in the assembly.

A detailed analysis of the technology status and research and deve1opment requirements cannot be made until fuel element design details are available. However, preliminary estimates of the status, research and development costs, and time requirements were made from the available information. These are given in Table 9.33.

\subsubsection{Preliminary Cost Estimate for Construction and Operation of a Commercial-Scale Plant}

Estimate cannot be made pending plant definition (Sect.9.7.3). 
Table 9.33. Research and Development Cost Estimates for Sphere-Pac Fabrication [NASAP Case 3.1.2 LWBR HEU(3)-Th, Recycled U(3), Advanced Breeder]

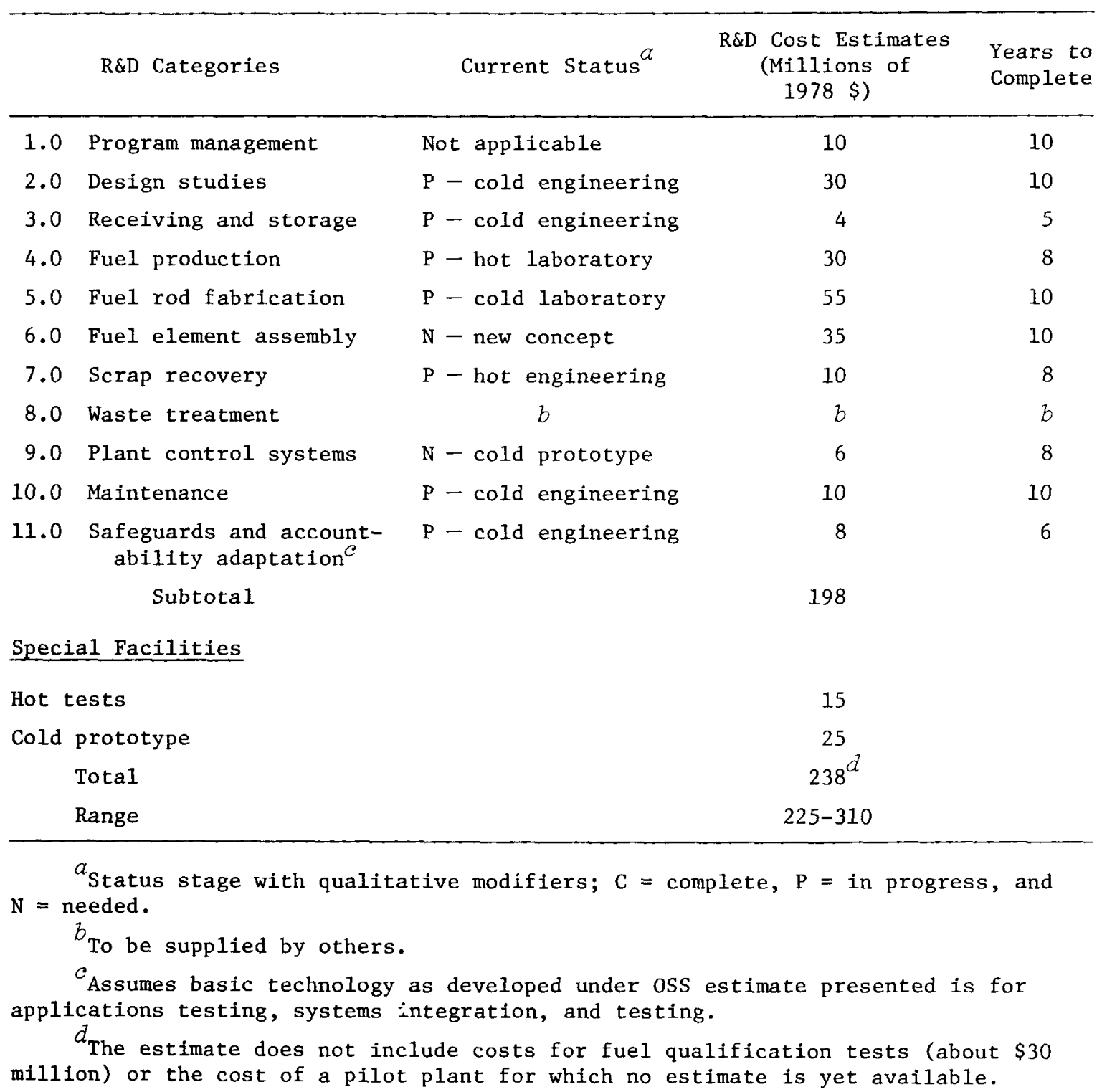




\subsection{NASAP CASE 3.2.1, LWBR MEU(5)-Th, PREBREEDER CONCEPT BASED ON TYPE I MODULES}

\subsubsection{Fuel Cycle Description}

The prebreeder would use less-than-20\%-enriched $235 \mathrm{U}$ fuel in the form of $\mathrm{UO}_{2}-\mathrm{ZrO}_{2}-\mathrm{CaO}$ (ternary) duplex pellets alternating with $\mathrm{ThO}_{2}$ pellets in the fuel rods. The duplex pellet would consist of a ternary annulus around a cylindrical thoria center. The spent fuel would be reprocessed in two stages to recover $\mathrm{U}, \mathrm{Pu}$, and $\mathrm{Th}$. The first stage would recover the $\mathrm{Pu}$ and ${ }^{235} \mathrm{U}$ remaining in the $\mathrm{UO}_{2}-\mathrm{ZrO}_{2}-\mathrm{CaO}$ annulus. The second stage would recover the bred $233 \mathrm{U}$ from the thoria. The $235 \mathrm{U}$ would be recycled to enrichment. The $\mathrm{Pu}$ and the bred $233_{\mathrm{U}}$ would be sent to secure storage and the Th would be sent to ten-year interim storage.

In this fuel cycle, only fresh fuel is fabricated in a contactoperated and contact-maintained (CO/CM) facility.

\subsubsection{Applicability to Current Fuel Element Design}

Available information on the fuel element design for this reactor cycle is given in Table 9.34. The design is similar to that for case 3.1.1 (Sect. 9.6) in that a duplex loading of $\mathrm{ThO}_{2}$ and $\mathrm{UO}_{2}-\mathrm{ZrO}_{2}-\mathrm{CaO}$ is required. The annular arrangement of the two fuel components, $\mathrm{ThO}_{2}$ on the inside and $(\mathrm{U}, \mathrm{Zr}, \mathrm{Ca})_{2}$ on the outside, would not be practical for sphere-pac loading. 
Table 9.34. Summary of DOE Division of Naval Reactors LWBR Fuel Module Parameters, Seed Assembly Portion [NASAP Case 3.2.1 - LWBR MEU(5)-Th, Prebreeder Concept Based on Type I Modules]

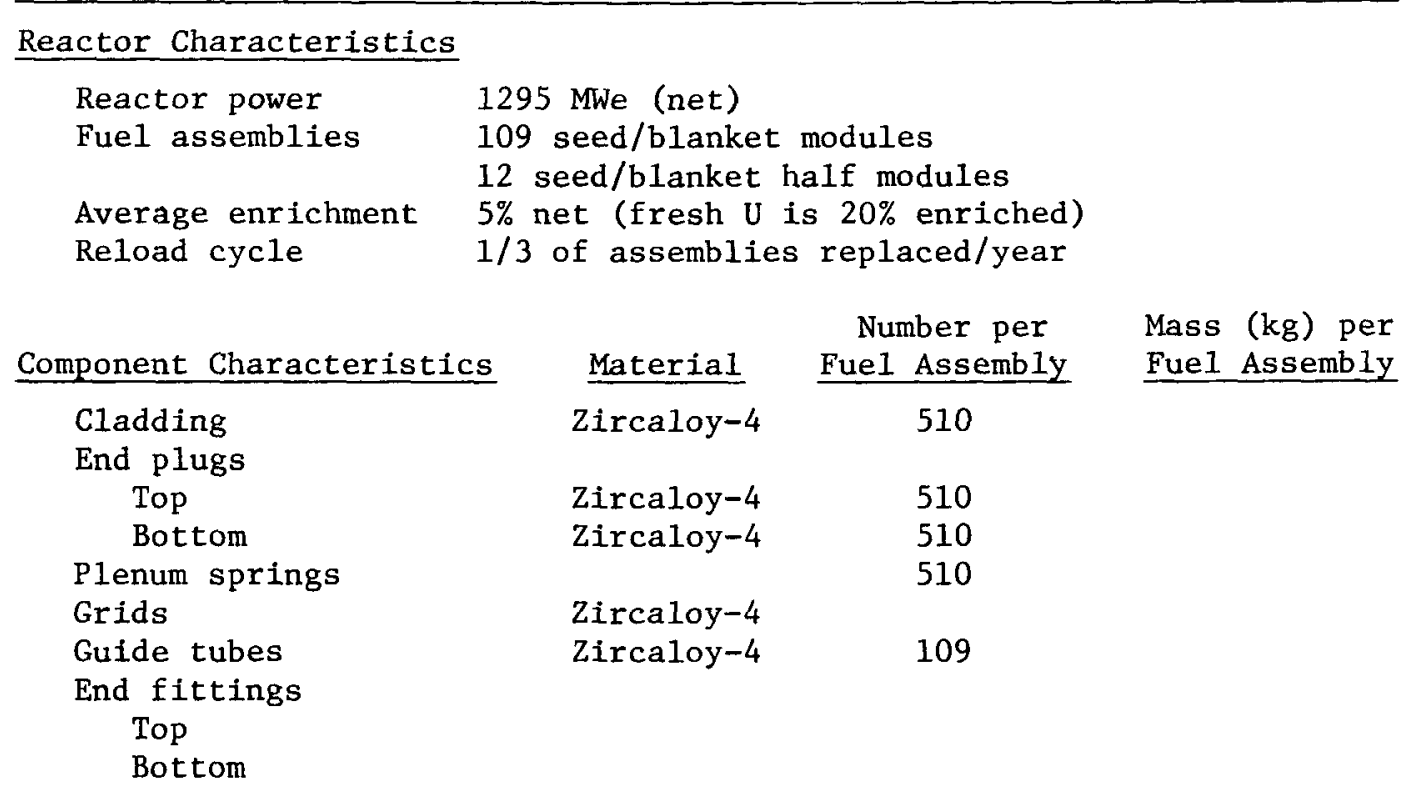

Fuel Rod Characteristics

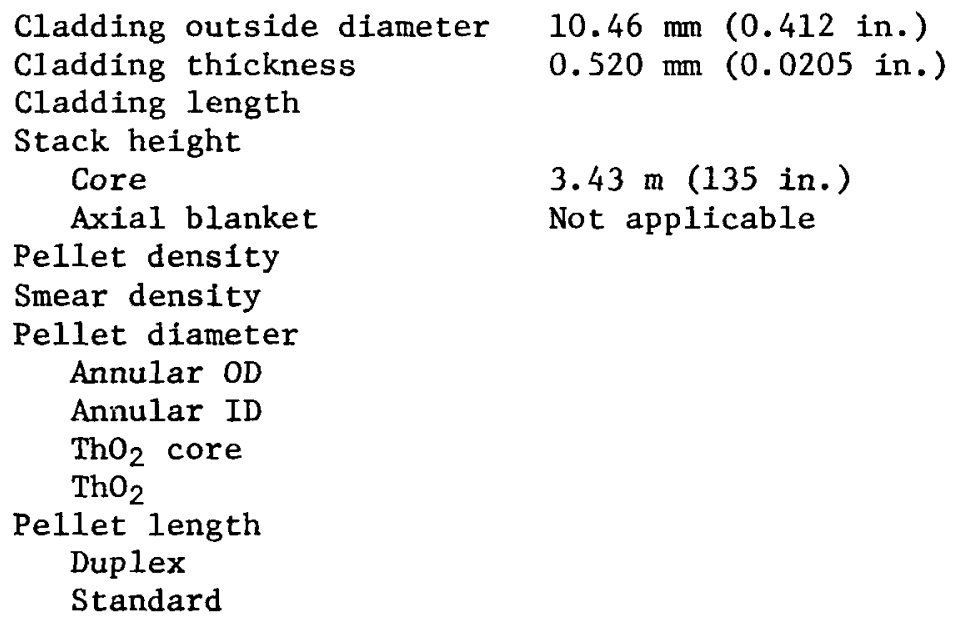

Fuel Assembly Characteristics

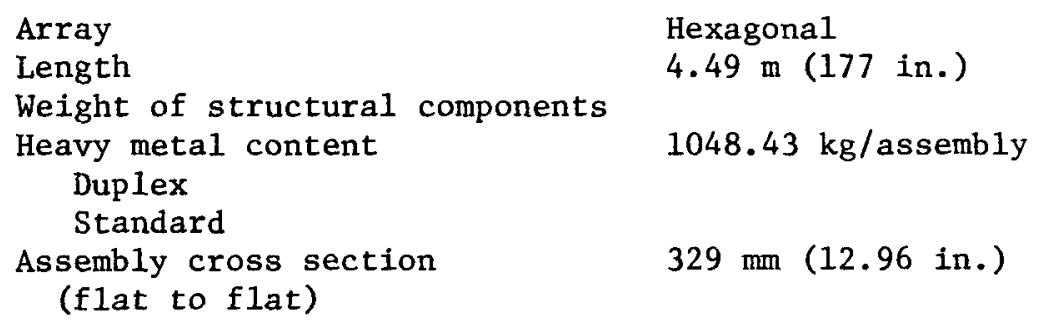

Hexagonal $4.49 \mathrm{~m}$ (177 in.)

$1048.43 \mathrm{~kg} /$ assembly

$329 \mathrm{~mm}$ (12.96 in.) 


\subsection{NASAP CASE 3.2.2, LWBR HEU(3)-Th BREEDER CONCEPT BASED \\ ON LWBR TYPE I MODULES}

\subsubsection{Fue1 Cycle Description}

The breeder would be fueled with a binary solid solution of highly enriched urania and thoria in the form of pellets. The spent fuel would be reprocessed to recover the ${ }^{233} \mathrm{U}$, which would be recycled to remote fuel fabrication. The thorium would be separated and also recycled to remote fabrication.

The prebreeder (case 3.2.1) and breeder concepts would be based on an array of hexagonal fuel modules, each of which would be geometrically identical with the Type I modules of the Shippingport LWBR core, except that the seed lattice of the breeder module would be altered to reduce the Zircaloy content. The core modules would be surrounded by reflecting blanket modules. Reactivity would be controlled by lifting or lowering movable fuel assemblies. The prebreeder and breeder phases would have the same physical arrangement except for the movable fuel assembly.

In this fuel cycle all fuel would be highly enriched $233 \mathrm{U}$ with the attendant $232 \mathrm{U}$ isotope. The high level of radioactivity associated with the $232 \mathrm{U}$ decay products would require a remotely operated and remote1y maintained (RO/RM) fabrication plant for both initial and recycle fuel.

\subsubsection{Applicability to Current Fuel Element Design}

Available information on the proposed fuel element design for this reactor cycle are given in Tables 9.35 and 9.36 for both the seed and blanket portions. Reference to the Shippingport design data ${ }^{6}$ indicates that the seed portion would have fuel rods with differing uranium and thorium contents in the fueled regions and with varying lengths of fuel and blanket material assembly locations.

Although the design detail available is insufficient to permit a complete applicability analysis, the ge1-sphere-pac process appears to be applicable. 
Table 9.35. Summary of DOE Division of Naval Reactors LWBR Fuel Module Parameters, Seed Assembly Portion [NASAP Case 3.2.2 - LWBR HEU(3)-Th, Breeder Concept Based on Type I Modules ]

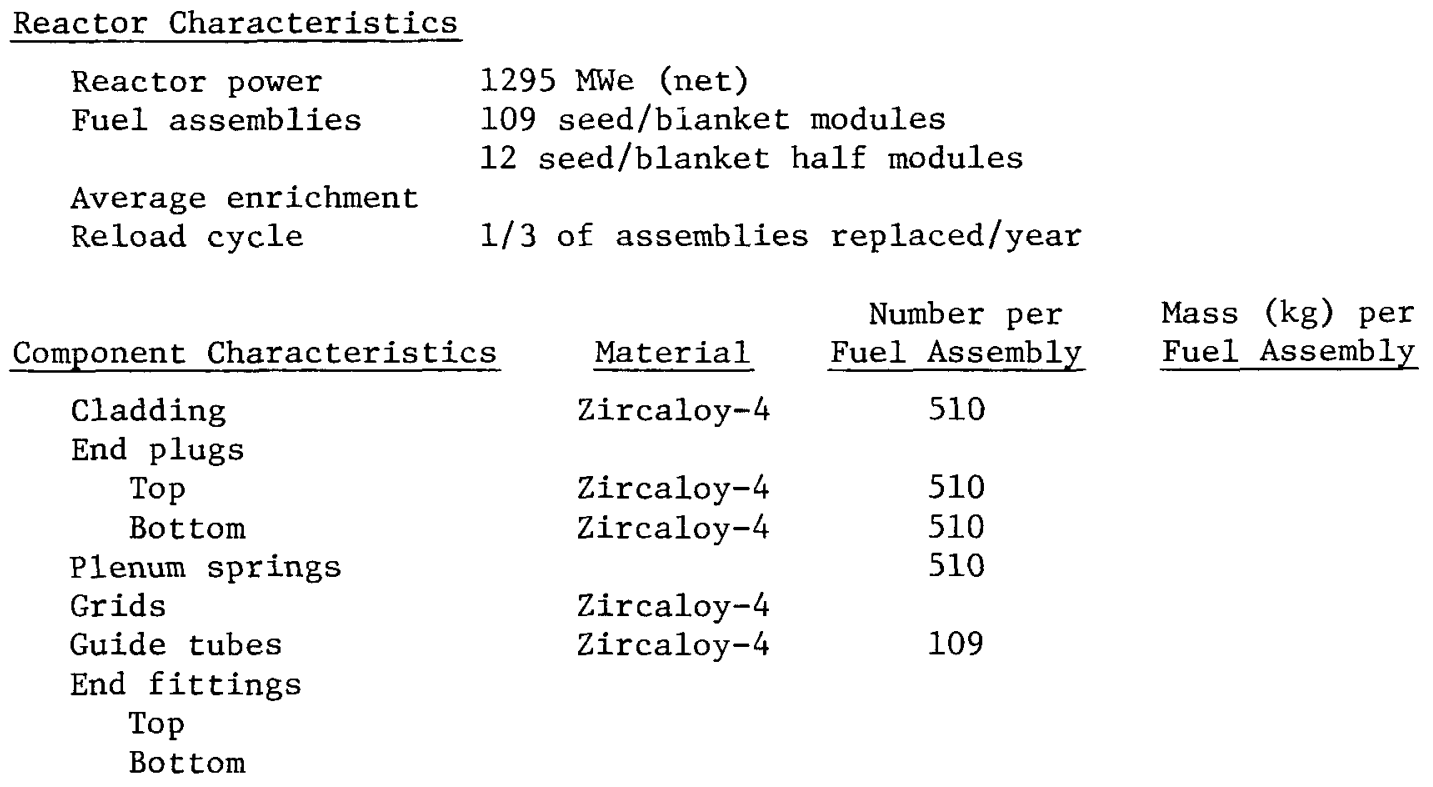

Fuel Rod Characteristics

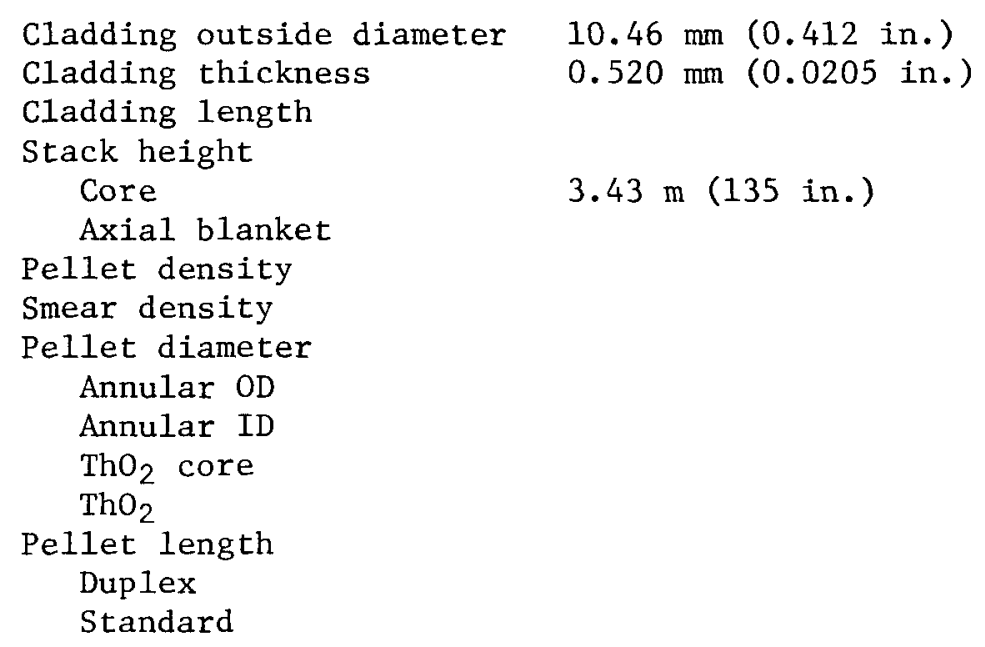

Fue1 Assemb1y Characteristics

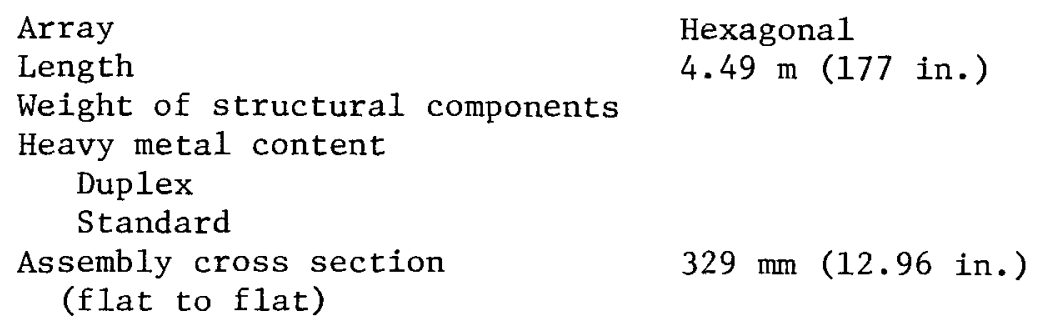


Table 9.36. Summary of DOE Division of Naval Reactors LWBR Fuel Module Parameters, Blanket Assembly Portion [NASAP Case 3.2.2 - LWBR HEU(3)-Th Breeder Concept Based on Type I Modules]

Reactor Characteristics

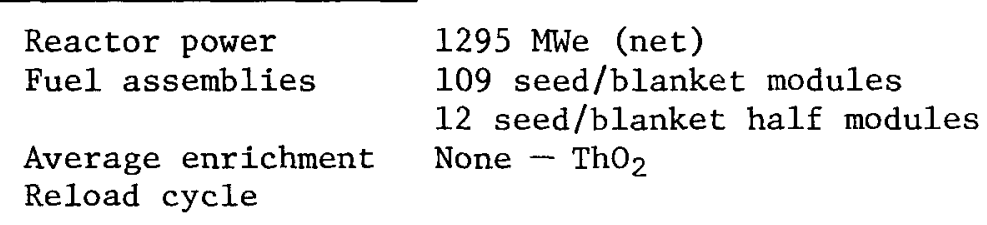

Fuel Rod Characteristics

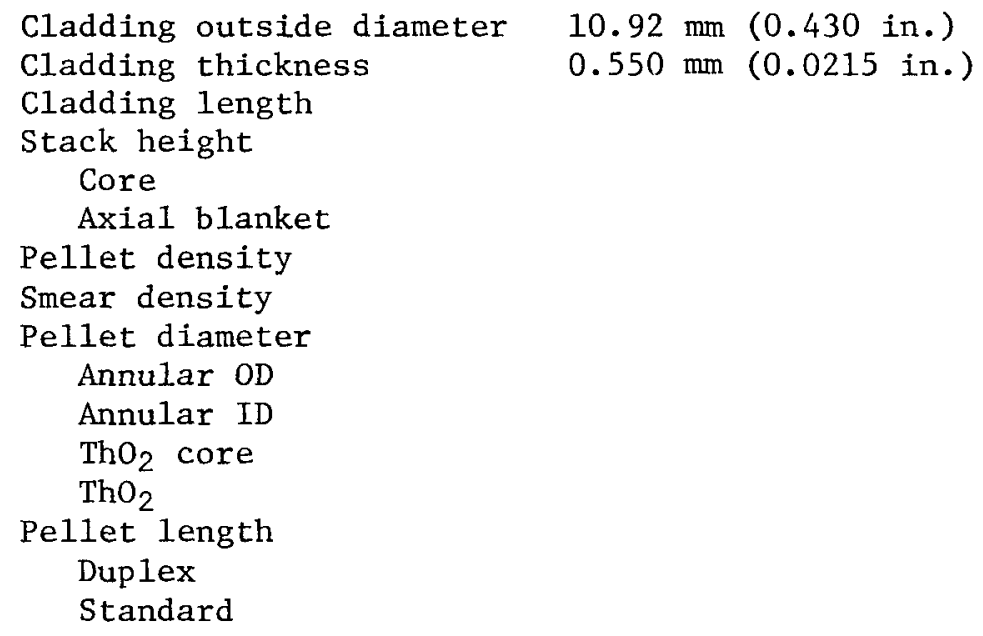

Fuel Assembly Characteristics

Array

Length

Weight of structural components

Heavy metal content

Duplex

Standard

Assembly cross section Not applicable

(flat to flat) 
The key considerations for sphere-pac applicability are the cladding inside diameter measurements and the required fuel smear density. The cladding IDs of $9420 \mu \mathrm{m}$ for the seed and $9820 \mu \mathrm{m}$ for the blanket in the reference designs are suitable for the sphere-pac process.

If required smear densities for the heavy metal in the seed and blanket portions do not exceed the $87 \%$ of theoretical density that is practical with the sphere-pac process, then the process is applicable to both portions.

\subsubsection{Definition of P1ant Production Requirements and Design Capacity}

Plant production requirements cannot be defined until additional design details are available for both the seed and blanket portions. In addition, cycle details will be needed to show the numbers of seed and blanket portions required at equilibrium for each reload.

\subsubsection{Estimates of Surge Storage Requirements, Scrap Production Rates, and Processing Rates for Functional Steps}

Estimates cannot be determined until plant has been defined.

\subsubsection{Analysis of Functional Technology Status, Research and Development Requirements, Cost, and Schedule}

The current technology status in terms of the fuel rod loading and inspection processes should be essentially that for the reference case discussed in Sect. 8 of this report as modified for case 1.4 (Sect.9.1). Fuel element assembly and inspection processes would be similar to those defined for the reference case. However, the multiple enrichments and varying rod loadings per element assembly location combined with possibly tighter assembly tolerances could significantly influence the remotely operated equipment requirements for both assembly and inspection.

A detailed analysis of the technology status and research and development requirements, costs, and schedules cannot be made without 
Table 9.37. Research and Development Cost Estimates for Sphere-Pac Fabrication [NASAP Case 3.2.2 LWBR HEU(3)-Th High Gain Converter, Spiked Recycle U(3)]

\begin{tabular}{|c|c|c|c|c|}
\hline & R\&D Categories & Current Status ${ }^{a}$ & $\begin{array}{l}\text { R\&D Cost Estimates } \\
\text { (Millions of } \\
1978 \text { \$) }\end{array}$ & $\begin{array}{l}\text { Years to } \\
\text { Complete }\end{array}$ \\
\hline 1.0 & Program management & Not applicable & 10 & 10 \\
\hline 2.0 & Design studies & $P-$ cold engineering & 30 & 10 \\
\hline 3.0 & Receiving and storage & $P$ - cold engineering & 4 & 5 \\
\hline 4.0 & Fuel production & P - hot 1aboratory & 30 & 8 \\
\hline 5.0 & Fuel rod fabrication & $P$ - cold laboratory & 55 & 10 \\
\hline 6.0 & Fuel element assembly & $N-$ new concept & 35 & 10 \\
\hline 7.0 & Scrap recovery & $\mathrm{P}-$ hot engineering & 10 & 8 \\
\hline 8.0 & Waste treatment & $b$ & $b$ & $b$ \\
\hline 9.0 & Plant control systems & $\mathrm{N}-$ cold prototype & 6 & 8 \\
\hline 10.0 & Maintenance & $P-\operatorname{cold}$ engineering & 10 & 10 \\
\hline 11.0 & $\begin{array}{l}\text { Safeguards and account- } \\
\text { ability adaptation }\end{array}$ & $\mathrm{P}-\operatorname{cold}$ engineering & 8 & 6 \\
\hline & Subtotal & & 198 & \\
\hline \multicolumn{5}{|c|}{ Special Facilities } \\
\hline \multicolumn{3}{|c|}{ Hot tests } & 15 & \\
\hline \multirow[t]{3}{*}{ Cold } & prototype & & 25 & \\
\hline & Total & & $238^{d}$ & \\
\hline & Range & & $225-310$ & \\
\hline
\end{tabular}

${ }^{a}$ Status stage with qualitative modifiers; $\mathrm{C}=$ complete, $\mathrm{P}=$ in progress, and $\mathrm{N}=$ needed.

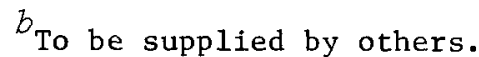

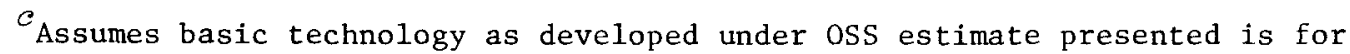
applications testing, systems integration, and testing.

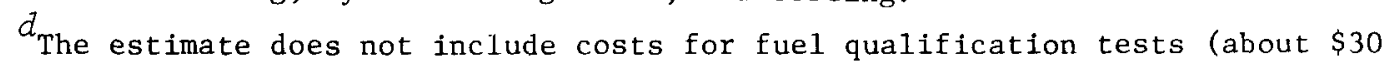
million) or the cost of a pilot plant for which no estimate is yet available. 
additional fuel element design details. However, a preliminary estimate is given in Table 9.37. This estimate should cover both the seed and blanket assembly portions.

9.9.6 Preliminary Cost Estimate for Construction and Operation of a Commercial-Scale Plant

Estimate cannot be made until plant requirements and definition are available. 
9.10 NASAP CASE 3.3.1, LWBR HEU(5), Th BACKFTT PREBREEDER

\subsubsection{Fue1 Cycle Description}

The backfit prebreeder would use $93 \%$-enriched $235_{\mathrm{U}}$ fuel in the form of binary solid solution $\mathrm{UO}_{2}-\mathrm{ThO}_{2}$ pellets. The spent fuel would be reprocessed to recover all uranium isotopes and would be stored for fabrication into fuel for the initial fuel requirements for the seed blanket breeder. The recovered thorium is sent to ten-year interim storage.

The prebreeder would consist of a PWR type core backfit into a PWR CE-80 vessel. The fuel would consist of a binary solid solution of urania and thoria. Reactivity control would be achieved by poison control rods and dissolved boric acid in the coolant. Spent fuel would be reprocessed to recover the uranium, which would be refabricated for the initial fuel loadings in the seed-blanket breeder.

In this fuel cycle, only fresh fuel is fabricated, so a contactoperated and contact-maintained ( $\mathrm{CO} / \mathrm{CM}$ ) facility is required.

\subsubsection{Applicability to Current Fuel Element Design}

Available information on the proposed fuel element design for this reactor cycle is given in Table 9.38. The element is essentially that used for the reference case and case 1.4 (Sect. 9.3). There is some uncertainty in the fuel content, which could be associated with a smear density change or other factors.

We have assumed the element loadings are the same as Case 1.4 for this applicability analysis.

The key considerations for sphere-pac applicability are the cladding inside diameter measurements and the required fuel smear density. The cladding ID of $8433 \mu \mathrm{m}$ in the reference design is suitable for the spherepac process. In addition, since the design smear density of $88 \%$ is essentially that achieved with experimental blended (three particle size) sphere-pac beds, the process is applicable. 
Table 9.38. Summary of DOE Division of Naval Reactors

LWBR Prebreeder Fuel Assembly Parameters

[NASAP Case 3.3.1 - LWBR HEU(5), Th Backfit Prebreeder]

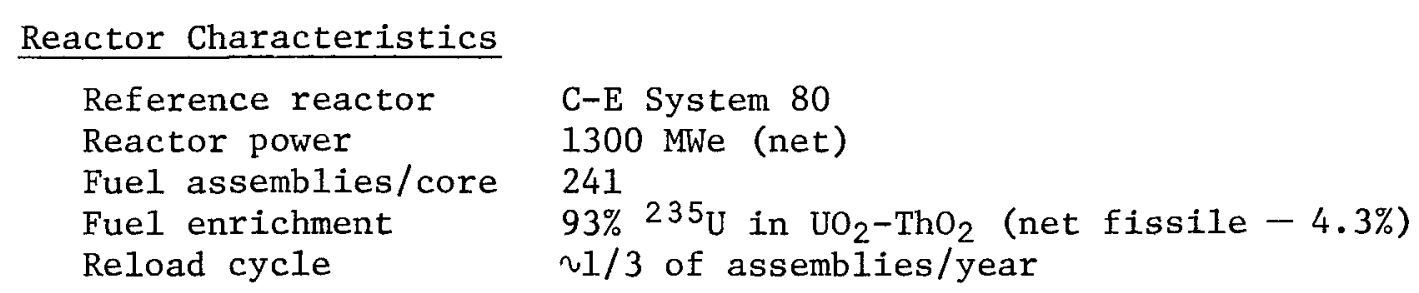

\begin{tabular}{|c|c|c|c|}
\hline Component Characteristics & Materials & $\begin{array}{c}\text { Number per } \\
\text { Fuel Assembly } \\
\end{array}$ & $\begin{array}{l}\text { Mass per Fuel } \\
\text { Assembly, kg }\end{array}$ \\
\hline Cladding & Zircaloy -4 & 236 & 113.47 \\
\hline \multicolumn{4}{|l|}{ End plugs } \\
\hline Top & Zircaloy -4 & 236 & 0.80 \\
\hline Bottom & Zircaloy-4 & 236 & 1.04 \\
\hline Plenum springs & 302 SS & 236 & 7.33 \\
\hline \multicolumn{4}{|l|}{ Guide tubes } \\
\hline Instrument & Zircaloy -4 & 1 & 2.10 \\
\hline Control element & Zircaloy -4 & 4 & 8.85 \\
\hline \multicolumn{4}{|l|}{ Spacer grids } \\
\hline Top & Zircaloy -4 & 1 & 0.82 \\
\hline Middle & Zircaloy -4 & 10 & 8.62 \\
\hline Bottom & A1loy 625 & 1 & 1.00 \\
\hline \multicolumn{4}{|l|}{ End fittings } \\
\hline Top & $\begin{array}{l}304 \text { SS with alloy } \\
\text { X-750 hold-down } \\
\text { springs }\end{array}$ & 1 & 18.60 \\
\hline Bottom & $\mathrm{CF}-8 \mathrm{SS}$ & 1 & 5.63 \\
\hline Insulator pellets & $\mathrm{Al}_{2} \mathrm{O}_{3}$ & 472 & 1.18 \\
\hline
\end{tabular}

Fue1 Rod Characteristics

cladding outside diameter

Cladding inside diameter

$9.70 \mathrm{~mm}(0.382$ in. $)$

Fue1 rod length

$8.43 \mathrm{~mm}$ (0.332 in.)

Fuel column height

$4.11 \mathrm{~m}$ (162 in.)

Fuel smear density

$3.81 \mathrm{~m}$ (150 in.)

Pellet diameter

$8.26 \mathrm{~mm}$ (0.325 in.)

Pellet length

$9.91 \mathrm{~mm}$ (0.390 in.)

Fue1 Assembly Characteristics

$\begin{array}{ll}\text { Array } & 16 \times 16 \text { square } \\ \text { Dimensions } & \\ \quad \text { Width } & 203 \mathrm{~mm} \text { (7.98 in.) } \\ \quad \text { Length } & 4.49 \mathrm{~m}(177 \mathrm{in.}) \\ \text { Mass of structural } & 169.73 \mathrm{~kg} \\ \quad \text { components } & \\ \text { Heavy metal content } & \sim 388 \mathrm{~kg}\end{array}$


9.10.3 Definition of Plant Production Requirements and Design Capacity

For the PWR $\left({ }^{235} \mathrm{U}, \mathrm{Th}\right) \mathrm{O}_{2}$ fuel cycle, the plant design assumptions are as follows.

1. The fuel design is the Combustion Engineering System $8016 \times 16$ rod array fuel assembly.

2. The plant production capacity is $520 \mathrm{t} \mathrm{HM} /$ year with the capability for simultaneous production of three enrichments.

3. The plant factor is 260 effective ful1-production days per year.

4. Plant design capacity: Overa11 $730 \mathrm{t} \mathrm{HM} /$ year about 5 fue 1 assemblies/d Each line of three $243 \mathrm{t} \mathrm{HM} /$ year $0.67 \mathrm{t} \mathrm{HM} / \mathrm{d}$ 406 fuel rods/d

1.7 fuel assemblies/d

5. Process design capacities are based on the line design capacities and the scrap and sample losses defined in Sect.9.10.4.

6. The facilities are designed to discharge no liquid waste other than treated sanitary sewage.

7. All process buildings and critical auxiliary support are designed and constructed in accordance with current United States Nuclear Regulatory Commission licensing requirements. Shielding is provided to limit dose rates to operating and maintenance personnel to $0.25 \mathrm{millirem} / \mathrm{h}$.

\subsubsection{Estimates of Surge Storage Requirements, Scrap Production Rates, and Processing Rates for Functional Steps}

Given the plant design assumptions defined in Sect.9.10.3, further commercial plant characteristics were derived.

To achieve the annual production rates, an analysis of the plant surge storage requirements and normal inventory was made, and the results of this analysis are given in Table 9.39.

Based on current technology and assuming reasonable extrapolations for commercial-scale developments, a preliminary estimate was made of the 
Table 9.39. Sphere-Pac Fabrication Plant Surge Storage Requirements and Normal Inventory [NASAP Case 3.1 LWBR HEU(5) - Th Backfit Prebreeder]

\begin{tabular}{|c|c|c|c|c|c|}
\hline \multirow{2}{*}{ Process Step } & \multirow{2}{*}{ Material } & \multicolumn{2}{|c|}{$\begin{array}{c}\text { Storage } \\
\text { Interval, d }\end{array}$} & \multicolumn{2}{|c|}{ Normal Inventory, $\mathrm{kg} \mathrm{HM}$} \\
\hline & & Norma1 & Maximum & $(\mathrm{U}, \mathrm{Th}) \mathrm{O}_{2}{ }^{a}$ & $\mathrm{ThO}_{2}$ Fines \\
\hline Feed storage & $\begin{array}{l}\text { Dried spheres } \\
\text { Sintered spheres }\end{array}$ & $\begin{array}{l}30 \\
30\end{array}$ & $\begin{array}{l}60 \\
60\end{array}$ & 50,000 & 13,000 \\
\hline Interim storage & $\begin{array}{l}\text { Dried spheres } \\
\text { Sintered spheres }\end{array}$ & $\begin{array}{l}1 \\
1\end{array}$ & $\begin{array}{l}2 \\
2\end{array}$ & 1,660 & 440 \\
\hline Furnace & $\begin{array}{l}\text { Dried to sintered } \\
\text { spheres }\end{array}$ & 1.2 & 2.4 & 2,000 & \\
\hline Post furnace & Sintered spheres & 0.5 & 1 & 830 & \\
\hline Interim storage & Sintered spheres & 0.36 & 0.72 & 600 & \\
\hline Main storage & $\begin{array}{l}\text { Sintered spheres } \\
\text { Sintered spheres }\end{array}$ & $\begin{array}{l}1.2 \\
1.5\end{array}$ & $\begin{array}{l}2.4 \\
2.9\end{array}$ & 2,100 & 660 \\
\hline $\begin{array}{l}\text { Loading, inspection } \\
\text { welding }\end{array}$ & Sintered spheres & 0.12 & 0.24 & 210 & 50 \\
\hline $\begin{array}{l}\text { Loaded, not inspected } \\
\text { rods }\end{array}$ & $\begin{array}{l}\text { Sintered spheres } \\
\text { in rods }\end{array}$ & 5 & 5 & 8,300 & 2,070 \\
\hline Rework and scrap & Sintered spheres & 2 & 5 & 410 & 75 \\
\hline Completed fuel rods & $\begin{array}{l}\text { Sintered spheres } \\
\text { in rods }\end{array}$ & 5 & 5 & 8,000 & 2,000 \\
\hline Assembly & $\begin{array}{l}\text { Rods in completed } \\
\text { assemblies }\end{array}$ & 15 & 30 & 24,000 & 6,000 \\
\hline
\end{tabular}

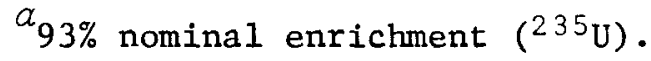


daily mass flows of heavy metal through the fabrication plant and the average production rate of heavy metal scrap materials from the various functional activities. These are presented in Table 9.40.

Given the above information, a preliminary evaluation of the processing rates for each functional step within the main fuel fabrication processes was made. The results of this analysis are summarized in Table 9.41.

9.10.5 Analysis of Functional Technology Status, Research and Development Requirements, Cost, and Schedule

The technology status of this system is quite similar to that of the reference case discussed in Sect. 8. The current status and research and development needs are summarized in Table 9.42. The primary difference between this denatured $235_{\mathrm{U}}-\mathrm{Th}$ fuel and the U-Pu fuel is the level of current development effort on sphere forming, calcination, and sintering. Currently $(\mathrm{U}, \mathrm{Pu})_{2}$ is under investigation in the United States, and the U$\mathrm{U}$-Th system would need to be initiated at the $\mathrm{U} / \mathrm{Th}$ ratio required for this fuel. However, since the $\mathrm{Th} / \mathrm{U}$ ratio is so high (19), this composition will behave essentially like thorium, which has been extensively investigated in the past.

In the fabrication process development, the fact that this fuel can be processed in a $\mathrm{CO} / \mathrm{CM}$ facility has a major impact on the research and development requirements. There would be no need for any hot engineering tests or a demonstration plant. Automation of the process would be required for good commercial application, so that cold prototype tests would be required for equipment through fuel rod inspection. No development is needed for fuel element assembly since current commercial practice should be applicable. It will be necessary to develop appropriate scrap recovery processes and to modify current commercial waste treatment practices to accommodate the increased nitrate wastes and reduced quantities of fluoride wastes in this cycle. 
Table 9.40. Heavy Metal Mass Flows and Average Scrap Production for a Sphere-Pac Fuel Fabrication Plant [NASAP Case 3.1.1 LWBR HEU(5) - Th Backfit Prebreeder]

\begin{tabular}{|c|c|c|c|c|c|c|}
\hline \multirow{3}{*}{ Processing Step } & \multicolumn{6}{|c|}{ Mass Flow, kg HM/d } \\
\hline & \multicolumn{2}{|c|}{ Daily Throughput } & \multicolumn{2}{|c|}{ Clean Scrap $b$} & \multicolumn{2}{|c|}{ Reject Scrap $^{c}$} \\
\hline & $(235 \mathrm{U}, \mathrm{Th}) \mathrm{O}_{2}{ }^{a}$ & $\mathrm{ThO}_{2}$ Fines & $\left({ }^{235} \mathrm{U}, \mathrm{Th}\right) \mathrm{O}_{2}{ }^{a}$ & $\mathrm{ThO}_{2}$ Fines & $\left({ }^{235} \mathrm{U}, \mathrm{Th}\right) \mathrm{O}_{2}{ }^{a}$ & $\mathrm{ThO}_{2}$ Fines \\
\hline Receiving and storage & 1662.3 & $437.8^{d}$ & & & & \\
\hline Sampling and batch loading & 1660.6 & & & & 1.7 & \\
\hline Weighing and sampling & & 437.4 & & & & 0.4 \\
\hline Calcining and sintering & 1659.8 & & & & 0.8 & \\
\hline Sphere upgrading & $1753.1^{e}$ & & & & 49.8 & \\
\hline Sphere sampling & 1749.6 & & & & 3.5 & \\
\hline Sphere storage & 1749.6 & 437.4 & & & & \\
\hline Fuel rod loading & 1749.6 & 437.4 & & & & \\
\hline Fuel rod scanning & 1662.1 & 415.5 & 84.0 & 21.0 & 3.5 & 0.9 \\
\hline Top component insertion & 1658.4 & 414.6 & 3.3 & 0.8 & 0.3 & 0.1 \\
\hline Rod welding and $x$ ray & 1658.4 & 414.6 & $f$ & $f$ & $f^{\circ}$ & $f$ \\
\hline Leak detection & 1658.4 & 414.6 & $f$ & $f$ & $f$ & $f$ \\
\hline Rod assay & 1625.3 & 406.3 & 31.5 & 7.9 & 1.7 & 0.4 \\
\hline Final rod inspection & 1608.4 & 402.1 & 16.3 & 4.1 & 0.7 & 0.2 \\
\hline Assembly inspection & 1600 & 400 & -8.0 & 2.0 & 0.3 & $\underline{0.1}$ \\
\hline Total & 20 & & 143.1 & 35.8 & 62.3 & 2.1 \\
\hline
\end{tabular}

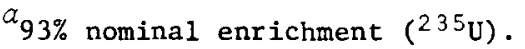

JInternally recycled.

${ }^{c}$ Collected, assayed, and externally recycled to reprocessing plant.

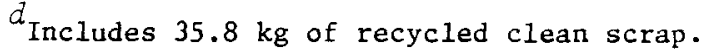

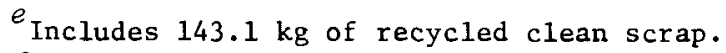

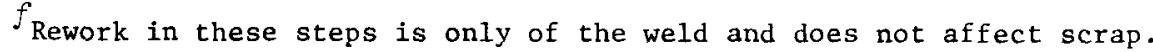




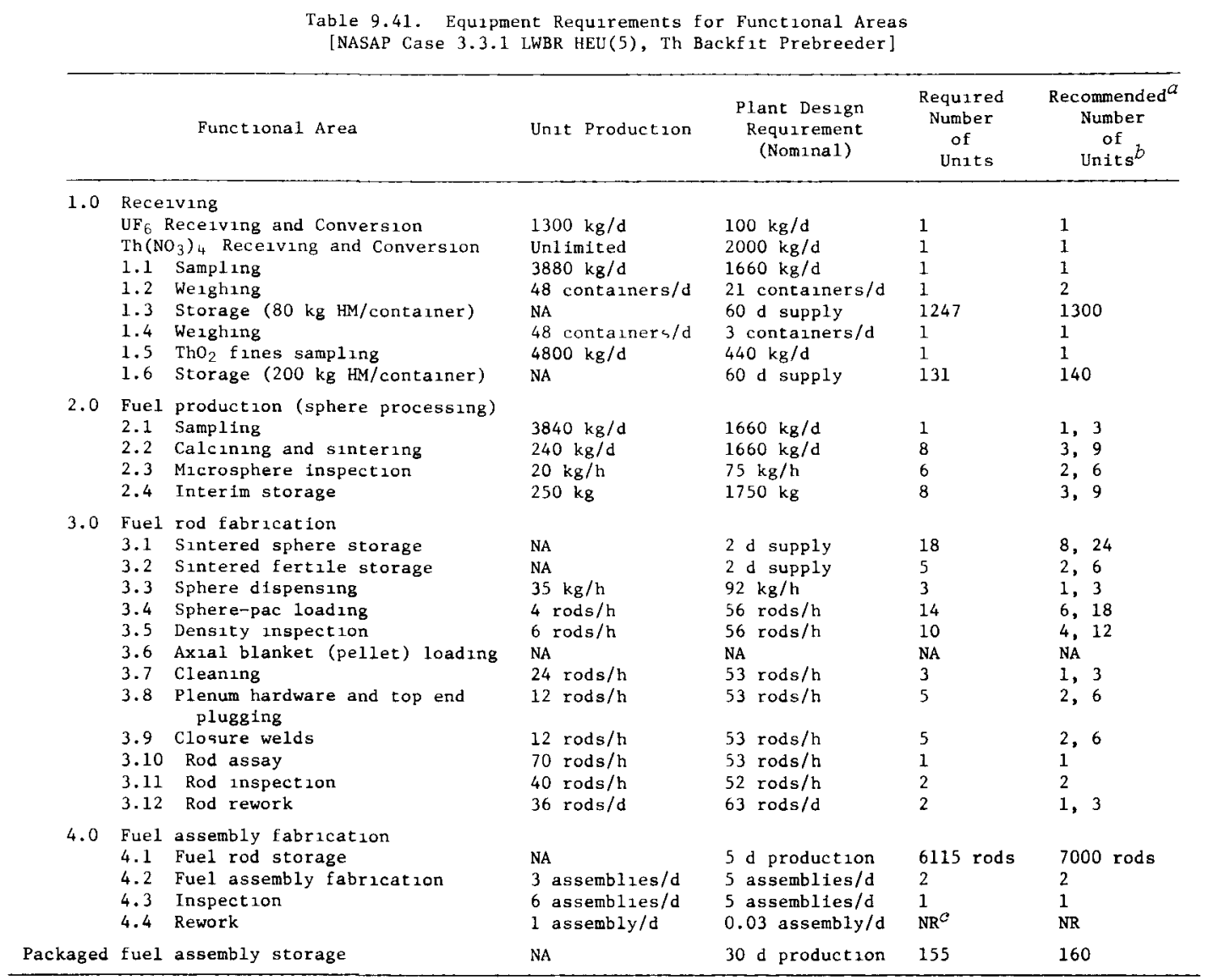

${ }^{a}$ Recommended units include consideration of spare capacity for operational reliability.

${ }^{b}$ Number of units is for the facility if a single number, otherwise, units per line, total units in facility.

${ }^{c}$ NR. not required. Use assembly equipment as available. 
Table 9.42. Research and Development Cost Estimates for Sphere-Pac Fabrication [NASAP Case 3.3.1 LWBR HEU(5), Th Backfit Prebreeder]

\begin{tabular}{|c|c|c|c|c|}
\hline & R\&D Categories & Current Status ${ }^{a}$ & $\begin{array}{c}\text { R\&D Cost Estimates } \\
\text { (Millions of } \\
1978 \$ \text { ) }\end{array}$ & $\begin{array}{l}\text { Years to } \\
\text { Complete }\end{array}$ \\
\hline 1.0 & Program management & Not applicable & 5 & 5 \\
\hline 2.0 & Design studies & N.- cold engineering & 5 & 5 \\
\hline 3.0 & Receiving and storage & $P$ - cold engineering & 0 & 0 \\
\hline 4.0 & Fuel production & $P-$ cold engineering & 19 & 5 \\
\hline 5.0 & Fuel rod fabrication & $P-$ cold engineering & 28 & 5 \\
\hline 6.0 & Fuel element assembly & $\mathrm{C}$ - commercial & 0 & 3 \\
\hline 7.0 & Scrap recovery & $\mathrm{N}-$ cold engineering & 3 & 2 \\
\hline 8.0 & Waste treatment & $b$ & $b$ & $b$ \\
\hline 9.0 & Plant control systems & $N$ - cold prototype & 5 & 5 \\
\hline 10.0 & Maintenance & $\mathrm{N}-$ cold prototype & 1 & 2 \\
\hline 11.0 & $\begin{array}{l}\text { Safeguards and account- } \\
\text { ability adaptation }{ }^{C}\end{array}$ & $P$ - cold engineering & 4 & 2 \\
\hline & Subtotal & & 70 & \\
\hline \multicolumn{5}{|c|}{ Special Facilities } \\
\hline \multicolumn{2}{|c|}{ Hot tests } & & NR & \\
\hline \multicolumn{2}{|c|}{ Cold prototype } & & 10 & \\
\hline & Tota1 & & $80^{d}$ & \\
\hline & Range & & $75-95$ & \\
\hline $\begin{array}{l}\mathrm{N}=\mathrm{n} \\
\mathrm{appli} \\
\mathrm{milli}\end{array}$ & $\begin{array}{l}a_{\text {Status stage with qualit }} \\
\text { eeded. } \\
b_{\text {To be supplied by others }} \\
c_{\text {Assumes basic technology }} \\
\text { cations testing, systems } \\
d_{\text {The estimate does not in }} \\
\text { on). }\end{array}$ & $\begin{array}{l}\text { tive modifiers; } C=\text { co } \\
\text { as developed under oss } \\
\text { ntegration, and testin } \\
\text { lude costs for fuel qu }\end{array}$ & $\begin{array}{l}\text { plete, } P=\text { in progre } \\
\text { estimate presented } \\
\text { lification tests (ab }\end{array}$ & $\begin{array}{l}\text { s, and } \\
\text { for } \\
\text { ut } \$ 5\end{array}$ \\
\hline
\end{tabular}


9.10.6 Preliminary Cost Estimate for Construction and Operation

The cost components that were estimated include capital costs for the facility and equipment, fuel assembly hardware costs, material and supply costs, and operating costs. 1-3 This estimate does include the production of (U, Th) $\mathrm{O}_{2}$ and $\mathrm{ThO}_{2}$ spheres as well as their subsequent processing.

Facility capital cost estimates were based on an analysis of the functional flow diagram for the process to indicate space requirements for each functional area and for each support area. Equipment requirements were identified, and costs associated with the equipment were estimated. Fuel assembly hardware requirements were based on the reference fuel assembly design parameters identified in Table 9.38. Estimates of the costs of the hardware items were obtained. Material and supply requirements were identified from the sphere-pac process description, and estimates of the costs of materials and supplies were obtained. Operating cost estimates included consideration of personnel, overhead, general and administrative expenses, and costs of utilities.

The facility was assumed to operate as a toll processing facility. That is, the operator fabricates customer-supplied fuel feed materials into finished fuel assemblies, and thus costs of thorium and uranium were not included in the cost estimates.

Unit costs for fabrication of fuel assemblies are determined by an economic analysis of the basic capital, hardware and material, and operating cost estimates. Basically, the economic analysis provides for the owner of the fuel fabrication facility to recover all capital, operating, and finance charges plus a return on investment, if appropriate, over the life of the plant.

In order to provide a range of prices (i.e., costs to a customer), economic analyses were based on government financing, financing appropriate for a conventional-risk (typical) industry, and financing appropriate for a high-risk industry. ${ }^{2}$ The estimated costs, costs derived from the economic analysis, and the unit costs based on the three different financing methods are summarized in Table 9.43. As may be observed from the table, the price for fabrication of $\left({ }^{235} \mathrm{U}, \mathrm{Th}\right) \mathrm{O}_{2}$ fuel is 
Table 9.43. Summary of Costs for Fabrication of Sphere-Pac PWR Fuel in a 2-t HM/d Facility [NASAP Case 3.3.1 LWBR HEU(5), Th Backfit Prebreeder]

\begin{tabular}{|c|c|c|c|c|c|c|c|c|c|}
\hline \multirow[b]{2}{*}{$\begin{array}{l}\text { Economic } \\
\text { Set }^{a}\end{array}$} & \multicolumn{4}{|c|}{ Estimated Costs, $\$$ million } & \multicolumn{4}{|c|}{ Derived Costs, $\$$ million } & \multirow[b]{2}{*}{$\begin{array}{c}\text { Unit } \\
\text { Cost } \\
(\$ / \mathrm{kg})\end{array}$} \\
\hline & Facility & Equipment & $\begin{array}{c}\text { Annual } \\
\text { Hardware } \\
\text { Plus } \\
\text { Materials }\end{array}$ & $\begin{array}{c}\text { Annual } \\
\text { Operating }\end{array}$ & $\begin{array}{c}\text { Owner's } \\
\text { Cost } \\
\text { During } \\
\text { Construction }\end{array}$ & $\begin{array}{c}\text { Charge on } \\
\text { Direct Capital } \\
\text { During } \\
\text { Construction }\end{array}$ & $\begin{array}{c}\text { Annual } \\
\text { Equipment } \\
\text { Reolacement } \\
\text { Cost }\end{array}$ & $\begin{array}{c}\text { Annual } \\
\text { Payment to } \\
\text { Decommissioning } \\
\text { Fund }\end{array}$ & \\
\hline A & 34 & 39 & 28 & 15 & 22 & 23 & 1.9 & 0.7 & 110 \\
\hline B & 34 & 39 & 28 & 15 & 22 & 33 & 1.9 & 0.7 & 140 \\
\hline C & 34 & 39 & 28 & 16 & 23 & 33 & 1.9 & 0.7 & 170 \\
\hline
\end{tabular}

$\alpha_{A}=$ Government financing; $B=$ Typical industrial financing; $c=$ High-risk industrial financing. 
expected to be in the range from $\$ 110$ to $\$ 170 / \mathrm{kg}$ depending on the financing technique that is employed. The recommended cost for comparison with other fuel cycles and methods of fabrication is the typical industry price of $\$ 140 / \mathrm{kg}$. 
9.11 NASAP CASE 3.3.2, LWBR HEU(3)-Th/Th SEED BLANKET BREEDER

\subsubsection{Fuel Cycle Description}

The seed-blanket breeder would use a PWR type vessel somewhat larger than present commercial PWRs. The fuel module would consist of seed and blanket regions. Reactivity control would be achieved by movable thoria rods in the seed region. The seed rods would consist of solid solutions of $\mathrm{UO}_{2}$ and $\mathrm{ThO}_{2}$ in pellet form. The blanket would consist of thoria pellets. The core and blanket would be reprocessed to recover the $233_{\mathrm{U}}$ and thorium, which would be recycled and mixed with makeup highly enriched $233_{\text {U from storage. }}$

Initially, the breeder would be loaded with fuel recycled from the prebreeder (mixed uranium-fissile fuel: bred $233_{\mathrm{U}}$ and nonfissioned $235_{\mathrm{U}}$ ). At equilibrium, the breeder would be fueled from recycled uranium (all isotopes) discharged from the breeder plus the mixed uranium isotope fuel discharged and stored from the prebreeder. The prebreeder fuel would be used to fuel the initial cycle of the breeder plus supply all makeup fuel needed.

For this cycle, only fuel containing $233 \mathrm{U}$ would be fabricated. The decay products of the $232 \mathrm{U}$ isotope associated with the $233 \mathrm{U}$ provide a high level of radioactivity. Consequently, a remotely operated and remotely maintained (RO/RM) facility would be required. This would be required whether or not the thorium is recycled with the uranium.

\subsubsection{Applicability to Current Fuel Element Design}

Available design information on the fuel element portions is given in Tables 9.44 and 9.45 for the seed and blanket portions, respectively.

Although there is insufficient information to permit a complete applicability analysis, the available information suggests the ge1-sphere-pac process will be applicable.

The key considerations for sphere-pac applicability are the cladding inside diameter measurements and the required fuel smear density. The cladding ID of $9780 \mu \mathrm{m}$ in the seed assembly reference design is suitable 
Table 9.44. Summary of DOE Division of Naval Reactors LWBR Seed Blanket Module Parameters, Seed Assembly Portion [NASAP Case 3.3.2 - LWBR HEU(3)-Th/Th Seed Blanket Breeder]

Reactor Characteristics

$\begin{array}{ll}\text { Reactor power } & 1000 \text { MWe (net) } \\ \text { Number of assemblies/core } & 169 \\ \text { Fuel enrichment } & \\ \text { Enrichment zones } & 1 \\ \text { Reload cycle } & \end{array}$

\begin{tabular}{|c|c|c|c|}
\hline Component Characteristics & Material & $\begin{array}{c}\text { Number per } \\
\text { Fuel Assembly }\end{array}$ & $\begin{array}{l}\text { Mass }(\mathrm{kg}) \text { per } \\
\text { Fuel Assembly }\end{array}$ \\
\hline Cladding & Zircaloy -4 & & \\
\hline \multicolumn{4}{|l|}{ End plugs } \\
\hline Top & Zircaloy -4 & & \\
\hline Bottom & Zircaloy -4 & & \\
\hline \multicolumn{4}{|l|}{ Plenum springs } \\
\hline Support shells & & 1 & \\
\hline \multicolumn{4}{|l|}{ Base plates } \\
\hline Top & & 1 & \\
\hline Bottom & & 1 & \\
\hline \multirow{2}{*}{\multicolumn{4}{|c|}{ Cover plate assemblies }} \\
\hline & & & \\
\hline \multicolumn{4}{|l|}{ Bottom } \\
\hline Support grids & Zircaloy -4 & & \\
\hline
\end{tabular}

Fue1 Rod Characteristics

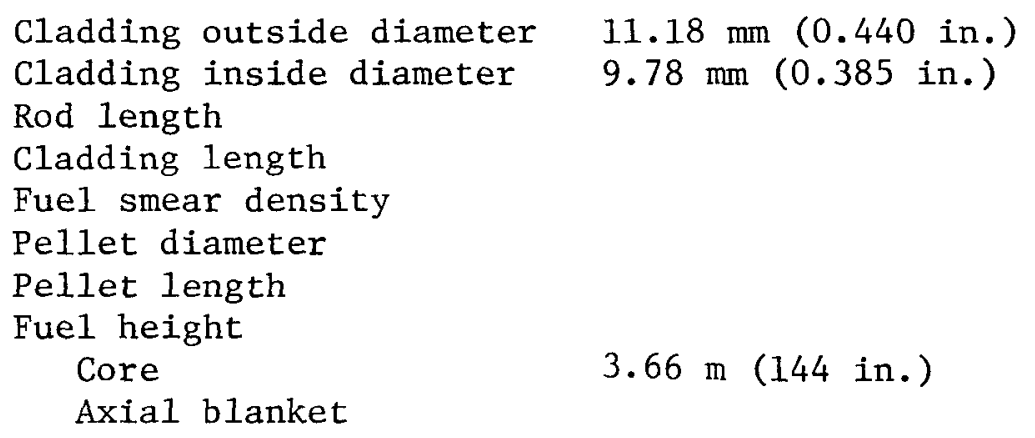

Fuel Assembly Characteristics

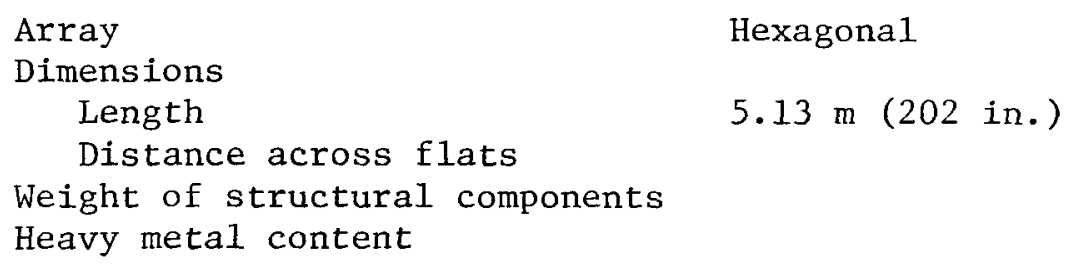


Table 9.45. Summary of DOE Division of Naval Reactors LWBR Seed Blanket Module Parameters, Blanket Assembly Portion [NASAF Case 3.3.2 - LWBR HEU(3)-Th/Th Seed Blanket Breeder]

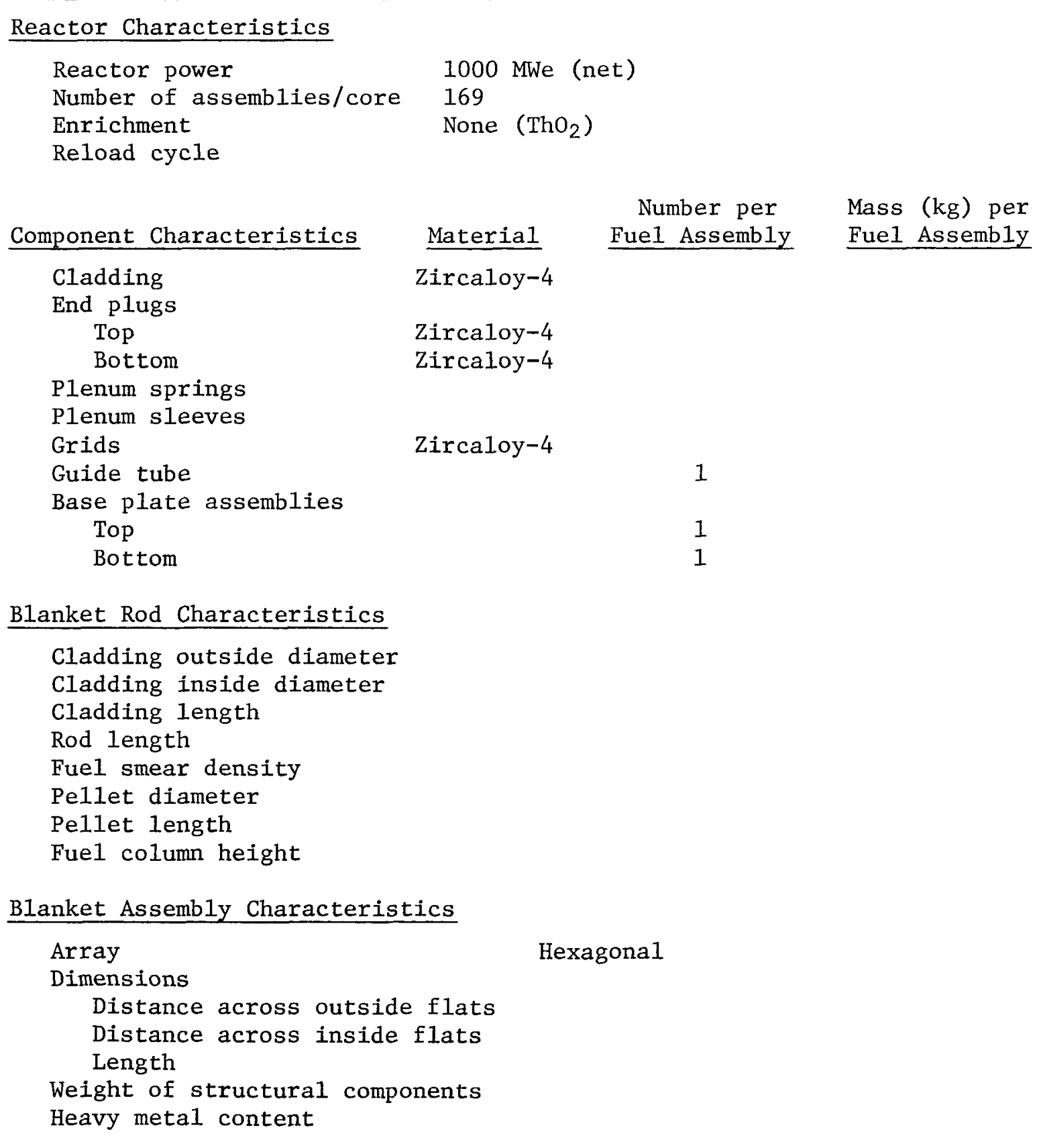


for the sphere-pac process. We have no information on the required cladding dimensions for the blanket portion of the assembly but have assumed it will be similar to the seed portion.

The other unknown is the proposed smear density for the fuel materials in either portion. However, if an acceptable smear density for both portions will not exceed $87 \%$ of theoretical density, the density achievable with the three-particle-size gel-sphere-pac process, the sphere-pac process would appear to be applicable to both portions of this assembly.

\subsubsection{Definition of Plant Production Requirements and Design Capacity}

Definition of the plant production requirements cannot be done until additional fuel element design information and the fuel cycle flows for both portions of the element are known.

\subsubsection{Estimates of Surge Storage Requirements, Scrap Production Rates, and Processing Rates for Functional Steps}

Estimates cannot be determined until the plant requirements (Sect. 9.11.3) have been defined.

\subsubsection{Analysis of Functional Technology Status, Research and} Development Requirements, Cost, and Schedule

The current technology status through the areas of fuel rod fabrication should be essentially that for the reference case discussed in Sect. 8 of this report. Fuel element assembly processes would be similar to those for the reference case but, assuming this seed blanket array is like the Shippingport design, 6 would be complicated by the two-portion (seed and blanket) requirement and indicated variations in fuel rod contents with position in the assembly.

A detailed analysis of the technology status and research and deve1opment requirements cannot be made until fuel element design details are 
available. However a preliminary estimate of the status, research and development costs, and time requirements was made on the available information. This is given in Table 9.46 .

9.11.6 Preliminary Cost Estimate for Construction and Operation of a Commercial-Scale Plant

An estimate cannot be made until the plant requirements (Sect. 9.11 .3 ) are defined. 
Table 9.46. Research and Development Cost Estimates for Sphere-Pac Fabrication [NASAP Case 3.3.2 LWBR HEU(3), Th/Th Seed Blanket Breeder]

\begin{tabular}{|c|c|c|c|c|}
\hline & R\&D Categories & Current Status ${ }^{a}$ & $\begin{array}{c}\text { R\&D Cost Estimates } \\
\text { (Mil1ions of } \\
1978 \$)\end{array}$ & $\begin{array}{l}\text { Years to } \\
\text { Complete }\end{array}$ \\
\hline 1.0 & Program management & Not applicable & 10 & 10 \\
\hline 2.0 & Design studies & $P-\operatorname{cold}$ engineering & 30 & 10 \\
\hline 3.0 & Receiving and storage & $P-$ cold engineering & 4 & 5 \\
\hline 4.0 & Fuel production & P - hot laboratory & 30 & 8 \\
\hline 5.0 & Fuel rod fabrication & $P$ - cold laboratory & 55 & 10 \\
\hline 6.0 & Fuel element assembly & $\mathrm{N}$ - new concept & 37 & 10 \\
\hline 7.0 & Scrap recovery & $\mathrm{P}-$ hot engineering & 10 & 8 \\
\hline 8.0 & Waste treatment & $b$ & $b$ & $b$ \\
\hline 9.0 & Plant control systems & $N-$ cold prototype & 6 & 8 \\
\hline 10.0 & Maintenance & $P-\operatorname{cold}$ engineering & 10 & 10 \\
\hline 11.0 & $\begin{array}{l}\text { Safeguards and account- } \\
\text { ability adaptation }\end{array}$ & $P-$ cold engineering & 8 & 6 \\
\hline & Subtotal & & 200 & \\
\hline \multicolumn{5}{|c|}{ Special Facilities } \\
\hline \multirow{4}{*}{$\begin{array}{l}\text { Hot t } \\
\text { Cold }\end{array}$} & ests & & 15 & \\
\hline & prototype & & 25 & \\
\hline & Total & & $240^{d}$ & \\
\hline & Range & & $230-310$ & \\
\hline $\begin{array}{l}\mathrm{N}= \\
\text { app1 }\end{array}$ & $\begin{array}{l}a_{\text {Status stage with qualita }} \\
\text { eeded. } \\
b_{\text {To be supplied by others. }} \\
c_{\text {Assumes basic technology }} \\
\text { cations testing, systems } \\
d_{\text {The estimatc does not ino }} \\
\text { on) or the cost of a pilot }\end{array}$ & $\begin{array}{l}\text { Live modifiers; } C=\text { con } \\
\text { as developed under oss } \\
\text { ategration, and testing } \\
\text { lude costs for fuel qua } \\
\text { plant for which no est }\end{array}$ & $\begin{array}{l}\text { plete, } P=\text { in progre } \\
\text { estimate presented } \\
\text { lification tests (ab } \\
\text { imate is yet availab }\end{array}$ & $\begin{array}{l}\text { s, and } \\
\text { for } \\
\text { ut } \$ 30 \\
\text { e. }\end{array}$ \\
\hline
\end{tabular}


9.12 NASAP CASE 5.1, GCFR U(5)-Pu/Th RECYCLE

\subsubsection{Fue1 Cycle Description}

This reactor-fuel combination is a gas-cooled fast reactor using a uranium-plutonium mixed-oxide homogeneous core and thorium oxide blankets. The core is coprocessed to recover plutonium mixed with uranium, which is blended with makeup Pu-U, 20\% fissile, from a safe secure storage facility and with depleted uranium to attain the desired $14.0 \%$ fissile assay and quantity for feed to the fuel fabrication operations. The core assemblies are preirradiated for spiking before shipment to the reactor. Depleted uranium is mixed with the recovered $233_{\mathrm{U}}$ from blanket reprocessing to produce $12 \%-f$ issile-assay denatured $233_{U}$ for storage or sale. The thorium recovered from blanket reprocessing is sent to storage for a decay period of at least ten years. New or decayed thorium is fabricated into blanket elements.

In this cycle only recycled core fuel element fabrication is considered. The reprocessing plant provides the coarse and medium sizes of spherical particles containing an appropriate amount of plutonium and uranium, as well as the $\mathrm{UO}_{2}$ fine particles. The $\mathrm{UO}_{2}$ fines are assumed to be sintered and ready for use in the fuel rod loading step. Alternatively, these $\mathrm{UO}_{2}$ fines could be produced in a process support area of this refabrication plant from depleted or natural uranium feed without significantly affecting facility and equipment requirements since they represent only about $10 \%$ of the total heavy metal in an element and could be manufactured in contact-operated and contact-maintained ( $\mathrm{CO} / \mathrm{CM})$ equipment. The $\mathrm{ThO}_{2}$ pellets in the axial blanket regions of each fuel rod are assumed to be available from an adjacent $\mathrm{CO} / \mathrm{CM}$ plant producing the radial blanket fuel assemblies for this reactor. The extended burnup on recycle of the core plutonium and the presence of the thorium will cause this material to have significant radioactivity, so a remotely operated and contactmaintained ( $R O / C M)$ facility is required.

\subsubsection{Applicability to Current Fuel Element Design}

The fuel element design chosen for this case is given in Table 9.47. 
Table 9.47. Summary of General Atomic Company GCFR Fuel Assembly Parameters [NASAP Case 5.1, GCFR U(5)-Pu/Th Recycle]

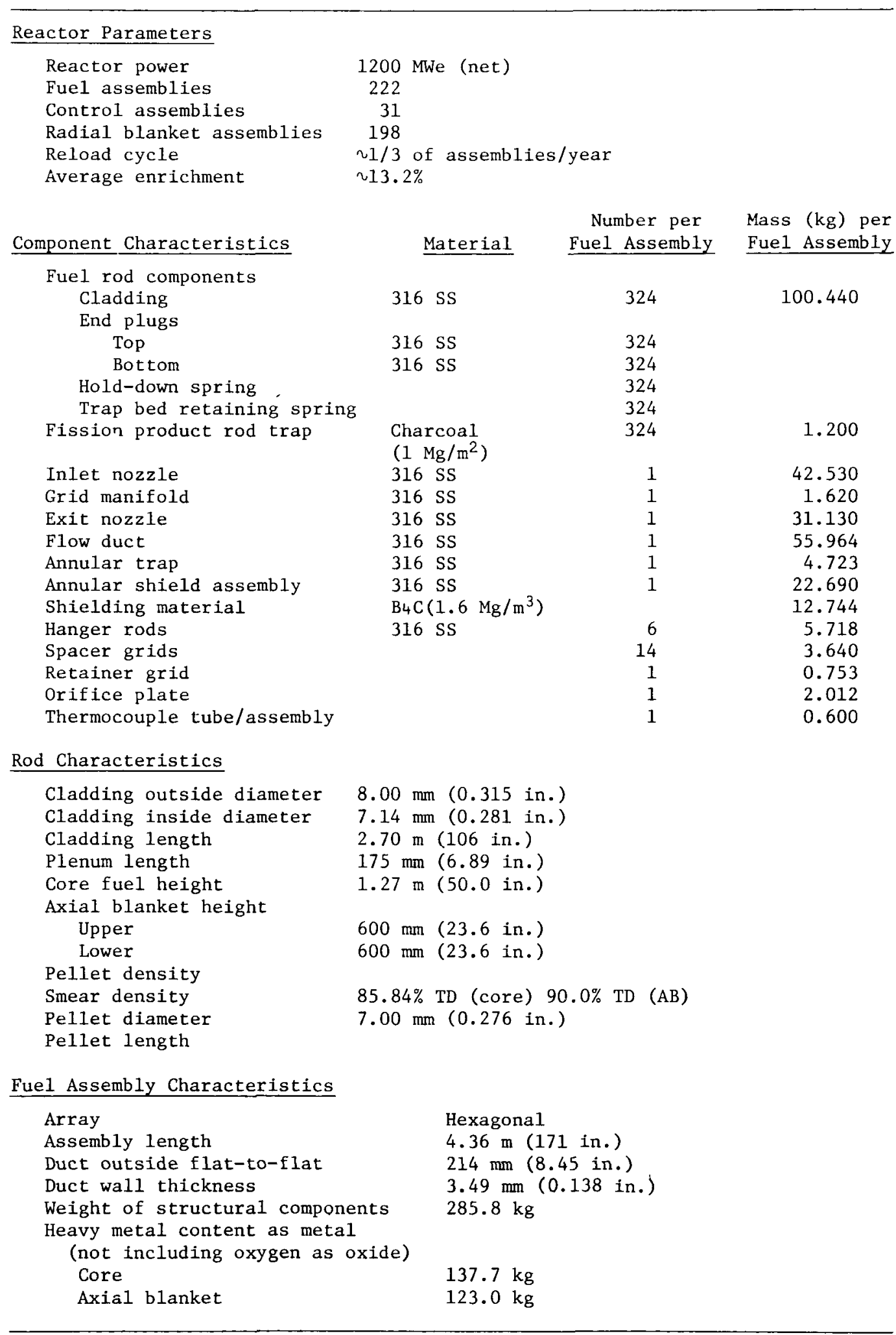


The key considerations for sphere-pac applicability are the cladding inside diameter measurements and the required fuel smear density. The cladding ID of $7140 \mu \mathrm{m}$ in the reference design is suitable for the spherepac process. The three-particle sphere-pac maximum loading density of approxinately $87 \%$ is well above the design smear density of $85.4 \%$. Thus, the ge1-sphere-pac option is judged to be applicable to this case.

\subsubsection{Definition of Plant Production Requirements and Design Capacity}

For this GCFR fuel cycle of $(\mathrm{U}, \mathrm{Pu})_{2}$ core material with $\mathrm{ThO}_{2}$ axial blankets, the plant design assumptions are as follows.

1. The fuel design is the General Atomic Company 1200-MWe GCFR design.

2. The plant production capacity is $480 \mathrm{t} \mathrm{HM} /$ year with the capability for simultaneous production of three enrichments.

3. The plant factor is 240 effective full-production days per year.

4. Plant design capacity:

Overa1l

Each line of three

\author{
$730 \mathrm{t} \mathrm{HM} /$ year \\ about 8 fuel assemblies/d \\ $243 \mathrm{t} \mathrm{HM} /$ year \\ $0.67 \mathrm{t} \mathrm{HM} / \mathrm{d}$ \\ 829 fuel rods/d \\ 2.6 fuel assemblies/d
}

5. Process design capacities are based on the line design capacities and the scrap and sample losses defined in Sect. 9.12.4.

6. The facilities are designed to discharge no liquid waste other than treated sanitary sewage.

7. All process buildings and critical auxiliary support are designed and constructed in accordance with current United States Nuclear Regulatory Commission licensing requirements. Shielding is provided to limit dose rates to operating and maintenance personnel to $0.25 \mathrm{millirem} / \mathrm{h}$.

In addition to these basic assumptions, we assumed that production from each fuel rod line is campaigned to provide a full reload segment for a single 1200-MWe (net) GCFR. Thus, the total heavy metal output for a 
given campaign is $19.3 \mathrm{t}$, and each campaign requires approximately 29 effective full-production days ( 44 calendar days). The total facility can support approximately 25 such reactors.

\subsubsection{Estimates of Surge Storage Requirements, Scrap Production Rates, and Processing Rates for Functional Steps}

Given the plant design assumptions defined in Sect. 9.12.3, further commercial plant characteristics were derived.

To achieve the annual production rates, an analysis of the plant surge storage requirements and normal inventory was made, and the results of this analysis are given in Table 9.48 .

Based on current technology and assuming reasonable extrapolations for commercial-scale developments, a preliminary estimate was made of the daily mass flows of heavy metal through the fabrication plant and the average production rate of heavy metal scrap materials from the various functional activities. These are presented in Table 9.49.

Given the above information, a preliminary evaluation of the processing rates for each functional step within the main fuel fabrication processes was made. The results of this analysis are summarized in Table 9.50.

9.12.5 Analysis of Functional Technology Status, Research and Development Requirements, Cost, and Schedule

The technology status of this system is quite similar to that of the reference case. The current status and research and development needs are summarized in Table 9.51.

While the general fabrication process descriptions are the same as those given for the reference gel-sphere-pac fuel fabrication, the design of the GCFR fuel assembly is considerably different. These differences in design result in modifications to the details for accomplishing the various functional activities and to the facility design details. These differences are discussed here as they apply specifically to case 5.1 . 
Table 9.48. Sphere-Pac Fabrication Plant Surge Storage Requirements and Normal Inventory [NASAP Case 5.1, GCFR U(5)-Pu/Th Recycle]

\begin{tabular}{|c|c|c|c|c|c|c|}
\hline \multirow{2}{*}{ Process step } & \multirow{2}{*}{ Material } & \multicolumn{2}{|c|}{$\begin{array}{c}\text { Storage } \\
\text { Interval, } \mathrm{d}\end{array}$} & \multicolumn{3}{|c|}{ Norma1 Inventory, $\mathrm{kg} \mathrm{HM}$} \\
\hline & & Norma1 & Maximum & $(\mathrm{Pu}, \mathrm{U}) \mathrm{O}_{2}$ & $\mathrm{UO}_{2}$ Fines & $\mathrm{ThO}_{2}$ Pellets \\
\hline Feed storage & $\begin{array}{l}\text { Dried spheres } \\
\text { Sintered spheres } \\
\text { Sintered pellets }\end{array}$ & $\begin{array}{l}30 \\
30 \\
30\end{array}$ & $\begin{array}{l}60 \\
60 \\
60\end{array}$ & 26,000 & 6900 & 12,900 \\
\hline Interim storage & $\begin{array}{l}\text { Dried spheres } \\
\text { Sintered spheres } \\
\text { Sintered pellets }\end{array}$ & $\begin{array}{l}1 \\
1 \\
1\end{array}$ & $\begin{array}{l}2 \\
2 \\
2\end{array}$ & 880 & 230 & 430 \\
\hline Furnace & $\begin{array}{l}\text { Dried to sintered } \\
\text { spheres }\end{array}$ & 1.2 & 2.4 & 1,050 & & \\
\hline Post furnace & Sintered spheres & 0.5 & 1 & 440 & & \\
\hline Interim storage & Sintered spheres & 0.36 & 0.72 & 320 & & \\
\hline Main storage & $\begin{array}{l}\text { Sintered spheres } \\
\text { Sintered spheres } \\
\text { Sintered pellets }\end{array}$ & $\begin{array}{l}1.2 \\
1.5 \\
1.5\end{array}$ & $\begin{array}{l}2.4 \\
2.9 \\
2.9\end{array}$ & 1,110 & 350 & 740 \\
\hline $\begin{array}{l}\text { Loading, inspection, } \\
\text { welding }\end{array}$ & $\begin{array}{l}\text { Sintered spheres } \\
\text { and pellets }\end{array}$ & 0.12 & 0.24 & 110 & 30 & 60 \\
\hline $\begin{array}{l}\text { Loaded, not inspected } \\
\text { rods }\end{array}$ & $\begin{array}{l}\text { Sintered spheres } \\
\text { in rods }\end{array}$ & 5 & 5 & 4,620 & 1160 & 2,580 \\
\hline Rework and scrap & $\begin{array}{l}\text { Sintered spheres } \\
\text { and pellets }\end{array}$ & 2 & 5 & 220 & 40 & 130 \\
\hline Completed fuel rods & $\begin{array}{l}\text { Sintered spheres } \\
\text { and pellets } \\
\text { in rods }\end{array}$ & 5 & 5 & 4,250 & 1060 & 4,740 \\
\hline Assembly & $\begin{array}{l}\text { Rods in completed } \\
\text { assemblies }\end{array}$ & 15 & 30 & 12,700 & 3170 & 14,200 \\
\hline
\end{tabular}


Table 9.49. Heavy Metal Mass Flows and Average Scrap Production for a Sphere-Pac Fuel Fabrication Plant [NASAP Case $5.1, \mathrm{U}(5)-\mathrm{Pu} / \mathrm{Th}$ Recycle]

\begin{tabular}{|c|c|c|c|c|c|c|c|c|c|}
\hline \multirow{3}{*}{ Processing Step } & \multicolumn{9}{|c|}{ Mass Flow, $\mathrm{kg} \mathrm{HM} / \mathrm{d}$} \\
\hline & \multicolumn{3}{|c|}{ Daily Throughput } & \multicolumn{3}{|c|}{ Clean Scrap $b$} & \multicolumn{3}{|c|}{ Reject $\operatorname{Scrap}^{C}$} \\
\hline & $(\mathrm{Pu}, \mathrm{U}) \mathrm{O}_{2}{ }^{\alpha}$ & $\begin{array}{l}\mathrm{UO}_{2} \\
\text { Fines }\end{array}$ & $\begin{array}{l}\text { Axial Blanket } \\
\mathrm{ThO}_{2} \text { Pellets }\end{array}$ & $(\mathrm{Pu}, \mathrm{U}) \mathrm{O}_{2}{ }^{a}$ & $\begin{array}{l}\mathrm{UO}_{2} \\
\text { Fines }\end{array}$ & $\begin{array}{l}\text { Axial Blanket } \\
\mathrm{ThO}_{2} \text { Pellets }\end{array}$ & $(\mathrm{Pu}, \mathrm{U}) \mathrm{O}_{2}$ & $\begin{array}{l}\mathrm{UO}_{2} \\
\text { Fines }\end{array}$ & $\begin{array}{l}\text { Axial Blanket } \\
\mathrm{ThO}_{2} \text { Pellets }\end{array}$ \\
\hline Receiving and storage & 877.7 & $231.2^{d}$ & 947.6 & & & & & & \\
\hline Sampling and batch loading & 876.8 & & & & & & 0.9 & & \\
\hline Weighing and sampling & & 231.0 & $946.7^{e}$ & & & & & 0.2 & 0.9 \\
\hline Calcining and sintering & 876.4 & & & & & & 0.4 & & \\
\hline Sphere upgrading & $925.7^{f}$ & & & & & & 26.3 & & \\
\hline Sphere sampling & 923.8 & & & & & & 1.9 & & \\
\hline Interim storage & 923.8 & 231.0 & 516.1 & & & & & & \\
\hline Fuel rod loading & 923.8 & 231.0 & 516.1 & & & & & & \\
\hline Fuel rod scanning & 877.7 & 219.4 & $980.5^{g}$ & 44.3 & 11.1 & 24.8 & 1.8 & 0.5 & 1.0 \\
\hline Top component insertion & 875.8 & 218.9 & 978.4 & 1.8 & 0.4 & 2.0 & 0.2 & 0.04 & 0.2 \\
\hline Rod welding and $x$ ray & 875.8 & 218.9 & 978.4 & $h$ & $h$ & $h$ & $h$ & $h$ & $h$ \\
\hline Leak detection & 875.8 & 218.9 & 978.4 & $h$ & $h$ & $h$ & $h$ & $h$ & $n$ \\
\hline Rod assay & 858.2 & 214.6 & 958.8 & 16.6 & 4.2 & 18.6 & 0.9 & 0.2 & 1.0 \\
\hline Final rod inspection & 849.3 & 212.3 & 948.0 & 8.6 & 2.1 & 9.6 & 0.3 & 0.1 & 0.4 \\
\hline Assembly inspection & 844.9 & 211.2 & 943.9 & 4.2 & 1.1 & 4.7 & 0.2 & $\underline{0.1}$ & 0.2 \\
\hline Tota1 & & 2000 & & 75.6 & 18.9 & 59.7 & 32.9 & 1.1 & 3.7 \\
\hline
\end{tabular}

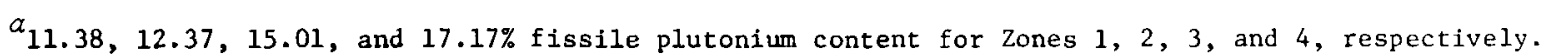

binternally recycled.

${ }^{c}$ Collected, assayed, and externally recycled to reprocessing plant.

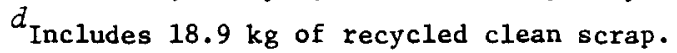

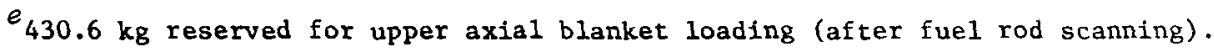

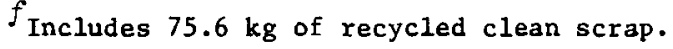

Includes $59.7 \mathrm{~kg}$ of recycled clean scrap plus $430.6 \mathrm{~kg}$ of fresh material for upper axial blanket loading.

$h_{\text {Rework }}$ in these steps is only of the weld and does not affect scrap. 
Table 9.50. Equipment Requirements for Functional Areas [NASAP Case 5.1, GCFR U(5)-Pu/Th Recycle]

\begin{tabular}{|c|c|c|c|c|c|}
\hline & Functional Area & Unit Production & $\begin{array}{c}\text { Plant Design } \\
\text { Requirement } \\
\text { (Nominal) }\end{array}$ & $\begin{array}{l}\text { Required } \\
\text { Number } \\
\text { of } \\
\text { Units }\end{array}$ & $\begin{array}{c}\text { Recommended } \\
\text { Number } \\
\text { of } \\
\text { Units }\end{array}$ \\
\hline 1.0 & 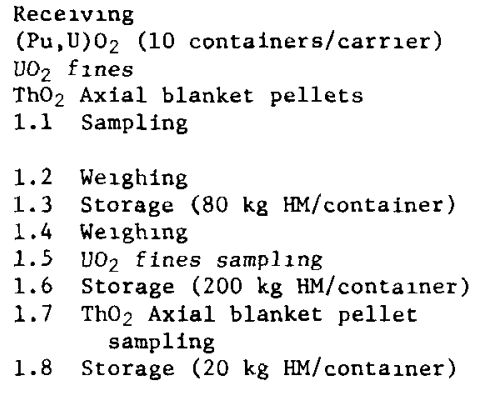 & $\begin{array}{l}1600 \mathrm{~kg} / \mathrm{d} \\
\text { Unlimited } \\
\text { Unlimited } \\
\mathrm{NA}^{C} \text {, done at reprocessing } \\
\text { plant } \\
48 \text { containers } / \mathrm{d} \\
\mathrm{NA} \\
48 \mathrm{containers} / \mathrm{d} \\
4800 \mathrm{~kg} / \mathrm{d} \\
\mathrm{NA} \\
4800 \mathrm{~kg} / \mathrm{d}\end{array}$ & $\begin{array}{l}11 \text { containers } / \mathrm{d} \\
60 \mathrm{~d} \text { supply } \\
2 \mathrm{conta} \text { ners } / \mathrm{d} \\
230 \mathrm{~kg} / \mathrm{d} \\
60 \mathrm{~d} \text { supply } \\
520 \mathrm{~kg} / \mathrm{d} \\
60 \mathrm{~d} \text { supply }\end{array}$ & $\begin{array}{l}1 \\
693 \\
1 \\
1 \\
69 \\
1\end{array}$ & $\begin{array}{l}2 \\
700 \\
1 \\
1 \\
70 \\
1\end{array}$ \\
\hline 2.0 & $\begin{array}{l}\text { Fuel production (sphere processing) } \\
2.1 \text { Sampling } \\
2.2 \text { Calcining and sintering } \\
2.3 \text { Microsphere inspection } \\
2.4 \text { Interim storage }\end{array}$ & $\begin{array}{l}3840 \mathrm{~kg} / \mathrm{d} \\
240 \mathrm{~kg} / \mathrm{d} \\
20 \mathrm{~kg} / \mathrm{h} \\
250 \mathrm{~kg}\end{array}$ & $\begin{array}{l}880 \mathrm{~kg} / \mathrm{d} \\
880 \mathrm{~kg} / \mathrm{d} \\
39 \mathrm{~kg} / \mathrm{h} \\
925 \mathrm{~kg}\end{array}$ & $\begin{array}{l}1 \\
4 \\
3 \\
4\end{array}$ & $\begin{array}{ll}1, & 3 \\
2, & 6 \\
1, & 3 \\
2, & 6\end{array}$ \\
\hline 3.0 & $\begin{array}{l}\text { Fuel rod fabrication } \\
3.1 \text { Sintered sphere storage } \\
3.2 \text { Sintered fertile storage } \\
3.3 \text { Sintered pellet storage } \\
3.4 \text { Sphere dispensing } \\
3.5 \text { Sphere-pac loading } \\
3.6 \text { Density inspection } \\
3.7 \text { Axial blanket (pellet) loading } \\
3.8 \text { Cleaning } \\
3.9 \text { plenum hardware and top end } \\
3.10 \text { plugging } \\
3.11 \text { Rod assay } \\
3.12 \text { Rod inspection } \\
3.13 \text { Rod rework }\end{array}$ & $\begin{array}{l}\text { NA } \\
\text { NA } \\
N A \\
35 \mathrm{~kg} / \mathrm{h} \\
4 \mathrm{rods} / \mathrm{h} \\
10 \mathrm{rods} / \mathrm{h} \\
12 \mathrm{rods} / \mathrm{h} \\
24 \mathrm{rods} / \mathrm{h} \\
12 \mathrm{rods} / \mathrm{h} \\
12 \mathrm{rods} / \mathrm{h} \\
100 \mathrm{rods} / \mathrm{h} \\
40 \mathrm{rods} / \mathrm{h} \\
36 \mathrm{rods} / \mathrm{d}\end{array}$ & $\begin{array}{l}2 \mathrm{~d} \text { supply } \\
2 \mathrm{~d} \text { supply } \\
2 \mathrm{~d} \text { supply } \\
48 \mathrm{~kg} / \mathrm{h} \\
113 \mathrm{rods} / \mathrm{h} \\
113 \mathrm{rods} / \mathrm{h} \\
107 \mathrm{rods} / \mathrm{h} \\
107 \mathrm{rods} / \mathrm{h} \\
107 \mathrm{rods} / \mathrm{h} \\
107 \mathrm{rods} / \mathrm{h} \\
107 \mathrm{rods} / \mathrm{h} \\
104 \mathrm{rods} / \mathrm{h} \\
130 \mathrm{rods} / \mathrm{d}\end{array}$ & $\begin{array}{l}23 \\
3 \\
39 \\
2 \\
29 \\
12 \\
9 \\
5 \\
9\end{array}$ & $\begin{array}{l}8,24 \\
1,3 \\
13,29 \\
1,3 \\
10,30 \\
4,12 \\
3,9 \\
2,6 \\
3,9 \\
3,9 \\
2 \\
3, \\
2,6\end{array}$ \\
\hline 4.0 & $\begin{array}{l}\text { Fuel assembly fabrication } \\
4.1 \text { Fuel rod storage } \\
4.2 \text { Fuel assembly fabrication } \\
4.3 \text { Inspection } \\
4.4 \text { Rework }\end{array}$ & $\begin{array}{l}\text { NA } \\
1.5 \text { assembliec/d } \\
3 \text { assemblies/d } \\
1 \text { assembly/d }\end{array}$ & $\begin{array}{l}5 \text { d production } \\
8 \text { assemblies } / d \\
8 \text { assemblies } / d \\
0.02 \text { assembly } / d\end{array}$ & $\begin{array}{l}12,490 \text { rods } \\
6 \\
3 \\
\mathrm{NR}^{d}\end{array}$ & $\begin{array}{l}13,000 \text { rods } \\
6 \\
3 \\
\text { NR }\end{array}$ \\
\hline & Packaged fuel assembly storage & NA & $30 \mathrm{~d}$ production & 230 & 230 \\
\hline
\end{tabular}

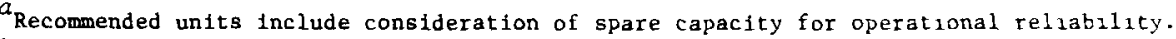

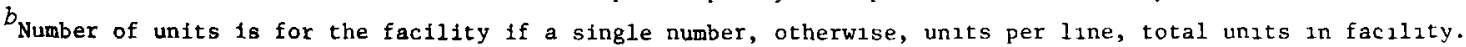

cNA: not applicable.

$d_{\mathrm{NR}}$ : not required. Use assembly equipment as avarlable. 
Table 9.51. Research and Development Cost Estimates for Sphere-Pac Fabrication [NASAP Case 5.1, GCFR U(5)-Pu/Th Recycle]

\begin{tabular}{|c|c|c|c|c|}
\hline & R\&D Categories & Current status ${ }^{a}$ & $\begin{array}{c}\text { R\&D Cost Estimates } \\
\text { (Millions of } \\
1978 \text { \$) }\end{array}$ & $\begin{array}{l}\text { Years to } \\
\text { Complete }\end{array}$ \\
\hline 1.0 & Program management & Not applicable & 10 & 10 \\
\hline 2.0 & Design studies & $\mathrm{N}-$ cold engineering & 25 & 10 \\
\hline 3.0 & Receiving and storage & $P$ - cold engineering & 4 & 5 \\
\hline 4.0 & Fuel production & $P-$ hot engineering & 30 & 8 \\
\hline 5.0 & Fue1 rod fabrication & $P$ - cold laboratory & 50 & 8 \\
\hline 6.0 & Fuel element assembly & $N-$ cold engineering & 50 & 10 \\
\hline 7.0 & Scrap recovery & $\mathrm{N}-$ hot 1aboratory & 7 & 5 \\
\hline 8.0 & Waste treatment & $b$ & $b$ & $b$ \\
\hline 9.0 & Plant control systems & $\mathrm{N}-$ cold prototype & 5 & 8 \\
\hline 10.0 & Maintenance & $P$ - cold engineering & 10 & 10 \\
\hline 11.0 & $\begin{array}{l}\text { Safeguards and account- } \\
\text { ability adaptation }\end{array}$ & $\mathrm{N}$ - hot 1aboratory & 6 & 6 \\
\hline & Subtotal & & 197 & \\
\hline \multicolumn{5}{|c|}{ Special Facilities } \\
\hline \multirow{4}{*}{$\begin{array}{l}\text { Hot } \\
\text { Cold }\end{array}$} & ests & & 10 & \\
\hline & prototype & & 25 & \\
\hline & Total & & $232^{d}$ & \\
\hline & Range & & $220-300$ & \\
\hline $\begin{array}{l}\mathrm{N}= \\
\text { app1 }\end{array}$ & $\begin{array}{l}a_{\text {Status stage with qualit }} \\
\text { leeded. } \\
b_{\text {To be supplied by others }} \\
c_{\text {Assumes basic technology }} \\
\text { cations testing, systems } \\
d_{\text {The estimate does not in }} \\
\text { (on) or the capital costs }\end{array}$ & $\begin{array}{l}\text { tive modifiers; } C=\text { cor } \\
\text { as developed under oss } \\
\text { integration, and testin } \\
\text { lude costs for fuel qua } \\
\text { a pilot plant estima }\end{array}$ & $\begin{array}{l}\text { plete, } P=\text { in progr } \\
\text { estimate presented } \\
\text { lification tests (al } \\
\text { ed at } \$ 160 \text { million. }\end{array}$ & $\begin{array}{l}s, \text { and } \\
\text { for } \\
\text { ut } \$ 20\end{array}$ \\
\hline
\end{tabular}


A gel-sphere-pac generic functional flow diagram is shown in Fig. 3.1 of Sect. 3.1.1 of this report. The main functions unique to the ge1sphere-pac process are fuel production (2.0) and fuel rod fabrication (3.0). Brief process descriptions of the various functional steps are given below.

Receiving and Storage. This functional area is similar to the reference case with the following exception. Thoria axial blanket pellets must be received from an adjacent blanket assembly fabrication facility and inspected before acceptance. The material may be handled in a contact area but must be stored in a shielded vault because of the radioactivity associated with the thorium.

Fuel Production. The fuel production processes are essentially the same as those described for the reference case including calcination, sintering, and inspection. However, since the axial blanket material $\left(\mathrm{ThO}_{2}\right.$ pellets) makes up approximately $47 \%$ of the total heavy metal content in a core fuel assembly, the quantity of material processed is significantly 1ess. The $\mathrm{ThO}_{2}$ blanket pellets are manufactured in an adjacent contactoperated and contact-maintained (CO/CM) facility.

Fuel Rod Fabrication. While most of the fuel rod fabrication processes are similar to the reference case additional steps are required to incorporate the axial blanket material and the internal gas traps. The lower axial blanket section is loaded into the fuel cladding before it is introduced into the cell. After the $(\mathrm{Pu}, \mathrm{U}) \mathrm{O}_{2}$ sphere-pac core region is loaded into each rod and inspected for density the upper axial blanket section is loaded. Although not significantly different in process functions, the need to install the internal fission product rod trap, containing charcoal, somewhat complicates the plenum component insertion step in the fuel rod loading. After the top end plug is welded in place, the inspection processes are reduced because the vented rod design precludes the need for a helium leak check of the rods. Decontamination of the external surfaces of the rods, if required, will necessitate a modified process to prevent decontaminating solutions from entering the fue 1 rods through the vent hole in the top end cap.

Fuel Assembly Operations. The fuel element assembly operations for this GCFR are unique. In many ways the assembly simulates a pressurized 
water reactor design in that the rods are supported and spaced by spacer grids. However, assembly is complicated by the increased number of these grids and the need to secure the threaded top end cap of each fuel rod into the grid manifold. After assembly and inspection of the rod-grid array, a flow duct must be installed around the package. These assembly operations will require development of special procedures and mechanical equipment to permit the remote mechanized assembly of these elements. The rod grid array inspection procedures should be similar to those required for pressurized water reactors.

Product Control Processes. These are the same as the reference case (see Sect. 4.1.2).

Scrap and Waste Processing and Disposal. The scrap handling processes are similar to the reference case (Sect. 4.1.2) with the added feature that all axial blanket pellets that are unloaded from an unsatisfactory rod are inspected, and acceptable pellets are recycled within the remotely operated facilities to form upper axial blankets.

\subsubsection{Preliminary Cost Estimate for Construction and Operation of a Commercial-Scale Plant}

The cost components that were estimated include capital costs for the facility and equipment, fuel assembly hardware costs, material and supply costs, and operating costs.

Facility capital cost estimates were based on an analysis of the functional flow diagram for the process to indicate space requirements for each functional area and for each support area. Equipment requirements were identified, and costs associated with the equipment were estimated. Fuel assembly hardware requirements were based on the reference fuel assembly design parameters identified in Table 9.47. The costs of the hardware items were estimated. Material and supply requirements were identified from the sphere-pac process description, and estimates of the costs of materials and supplies were obtained. Operating cost estimates included consideration of personnel, overhead, general and administrative expenses, and costs of utilities. 
The facility was assumed to operate as a toll processing facility. That is, the operator fabricates customer-supplied fuel feed materials into finished fuel assemblies, and thus costs of plutonium, uranium, and thorium were not included in the cost estimates. The hardware and material costs include the costs associated wih the production of the $\mathrm{ThO}_{2}$ pellets for the axial blanket.

Unit costs for fabrication of fuel assemblies are determined by an economic analysis of the basic capital, hardware and material, and operating cost estimates. Basically, the economic analysis provides for the owner of the fuel fabrication facility to recover all capital, operating, and finance charges plus a return on investment, if appropriate, over the life of the plant.

In order to provide a range of prices (i.e., costs to a customer), economic analyses were based on government financing, financing appropriate for a conventional-risk (typical) industry, and financing appropriate for a high-risk industry. 2 The estimated costs, costs derived from the economic analysis, and the unit costs based on the three different financing methods are summarized in Table 9.52. As may be observed from the table, the price for fabrication is expected to be in the range from $\$ 370$ to $\$ 720 / \mathrm{kg}$ depending on the financing technique that is employed. The recommended cost for comparison with other fuel cycles and methods of fabrication is the typical industry cost of $\$ 580 / \mathrm{kg}$ of heavy metal. As with all the cost estimates in this report, the prices are based on the mass of all heavy metal in the finished assembly. For this case, this includes the thorium in the axial blankets. 
Table 9.52. Summary of Costs for Fabrication of Sphere-Pac PWR Fuel in a 2-t HM/d Facility [NASAP Case 5.1, GCFR U(5)-Pu/Th Recycle]

\begin{tabular}{|c|c|c|c|c|c|c|c|c|c|}
\hline \multirow[b]{2}{*}{$\begin{array}{c}\text { Economic } \\
\text { Set }^{\alpha}\end{array}$} & \multicolumn{4}{|c|}{ Estimated Costs, \$ million } & \multicolumn{4}{|c|}{ Derived Costs, $\$$ million } & \multirow[b]{2}{*}{$\begin{array}{l}\text { Unit } \\
\text { Cost } \\
(\$ / \mathrm{kg})\end{array}$} \\
\hline & Facility & Equipment & $\begin{array}{c}\text { Annual } \\
\text { Hardware } \\
\text { Plus } \\
\text { Materials }\end{array}$ & $\begin{array}{c}\text { Annual } \\
\text { Operating }\end{array}$ & $\begin{array}{c}\text { Owner's } \\
\text { Cost } \\
\text { During } \\
\text { Construction }\end{array}$ & $\begin{array}{c}\text { Charge on } \\
\text { Direct Capital } \\
\text { During } \\
\text { Construction }\end{array}$ & $\begin{array}{c}\text { Annual } \\
\text { Equipment } \\
\text { Replacement } \\
\text { Cost }\end{array}$ & $\begin{array}{c}\text { Annual } \\
\text { Payment to } \\
\text { Decommissioning } \\
\text { Fund }\end{array}$ & \\
\hline A & 250 & 265 & 64 & 27 & 39 & 135 & 13 & 1.2 & 370 \\
\hline B & 250 & 265 & 64 & 28 & 40 & 200 & 13 & 1.3 & 580 \\
\hline $\mathrm{C}$ & 250 & 265 & 64 & 29 & 41 & 200 & 13 & 1.3 & 720 \\
\hline
\end{tabular}

$a_{A}=$ Government financing; $B=$ Typical industrial financing; $C=$ High-risk industrial financing.

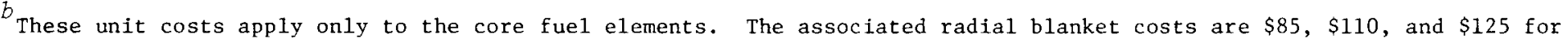
economic sets $A, B$, and $C$, respectively. 
9.13 NASAP CASE 6.1, LMFBR U-Pu/U/U RECYCLE (GENERAL ELECTRIC REFERENCE)

\subsubsection{Fuel Cycle Description}

This reactor-fuel cycle combination is an LMFBR using recycled coprocessed $\mathrm{U}-\mathrm{Pu}$ mixed oxide in a homogeneous core and recycled uranium mixed with makeup depleted uranium in the axial and radial blanket assemblies. The core fuel is reprocessed separately from the blanket assemblies. All the coprocessed, recovered $\mathrm{Pu}-\mathrm{U}$ from the core is mixed with makeup uranium and some of the U-Pu recovered from blanket reprocessing is used for feed material to core fabrication. The excess coprocessed U-Pu from blanket reprocessing is sent to secure storage for later use in LWRs or LMFBRs. All other recovered uranium from blanket reprocessing is recycled to blanket fabrication after being mixed with makeup depleted uranium. In this cycle analysis only fabrication of the core assemblies is considered. The products of the reprocessing plant are highly decontaminated and include the coarse and medium sizes of spherical particles with the appropriate uranium-to-plutonium ratio and the recycled $\mathrm{UO}_{2}$ fines. The assumption was that excess uranium from the reprocessing plant and/or makeup depleted uranium will be fabricated by the pellet process into radial blanket assemblies in an adjacent contact-operated and contactmaintained (CO/CM) facility. Urania pellets from that adjacent facility will be used in the core fabrication facility for the axial blankets in the core assemblies.

The extended burnup of the recycle plutonium will cause this material to have significant radioactivity; consequently, a remotely operated and contact-maintained ( $\mathrm{RO} / \mathrm{CM}$ ) facility is required for the core assemblies for this cycle.

\subsubsection{Applicability to Current Fuel Element Design}

The core fuel element design chosen for this cycle is given in Table 9.53.

The key considerations for sphere-pac applicability are the cladding inside diameter measurements and the required fuel smear density. The 
Table 9.53. Summary of General Electric Reference LMFBR Fuel Assembly Parameters

(NASAP Case 6.1, LMFBR U-Pu/U/U Recycle)

\section{Reactor Characteristics}

Reactor power
Fuel assemblies
Inner blanket assemblies
Radial blanket assemblies
Control assemblies
Removable shield assemblies
Fissile enrichment, \%

Component Characteristics

Fuel cladding

End plugs

Top

Bottom

Reflector rods

Plenum springs

Spacers

Wire wrap

Attachment rails

Locking pins

Shield and inlet assemblies

Duct and upper handling socket

\section{Fue1 Rod Characteristics}

Fue1 cladding outside diameter

Fuel cladding inside diameter

Fuel rod length

Plenum length

Upper

Lower

Core fuel height

Axial blanket height Upper

Lower

Pellet density

Fuel smear density

Pellet diameter

Pellet length

Wire wrap diameter

Bonding

Fuel Assembly Characteristics

Array
Fuel assembly length
Duct outside flat-to-flat
Duct wall thickness
Mass of structural components
Heavy metal content
$\quad$ Core
$\quad$ Axial blanket

1000 MWe (net)

252 (150 Zone 1; 102 Zone 2)

Not applicable

198

19

240

Zone $1-10.24$, zone $2,-14.36$

Number per Mass ( $\mathrm{kg})$ per

Material Fuel Assembly Fuel Assembly

Improved 316 SS 271

Improved 316 SS 271

Improved 316 SS 271

316 SS

271

Improved 316 SS 1

Improved 316 SS 1

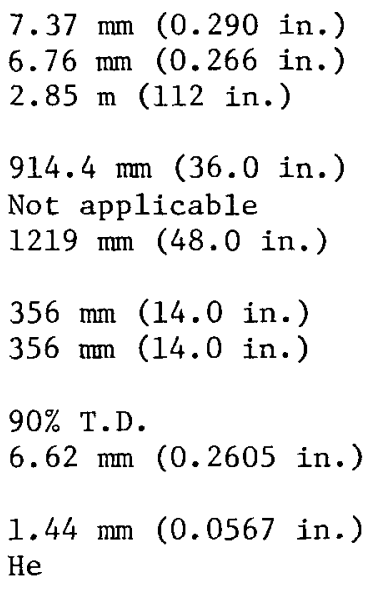

Hexagona1

$154.5 \mathrm{~mm}$ (6.083 in.)

$3.18 \mathrm{~mm}$ (0.125 in.)

$103.74 \mathrm{~kg}$

$63.48 \mathrm{~kg}$ 
cladding ID of $6760 \mu \mathrm{m}$ in the reference design is suitable for the spherepac process. Although the specified smear density of $90 \%$ of theoretical is above that currently achieved with experimental blended (three particle size) sphere-pac beds, we have assumed that the process is applicable through a slight lowering of this design requirement.

\subsubsection{Definition of Plant Production Requirements and Design Capacity}

For this LMFBR (U, Pu) $\mathrm{O}_{2}-\mathrm{UO}_{2}$ fuel cycle, the plant design assumptions are 1isted below. The heavy metal throughput for this plant and all cases involving axial blanket fuel is based on the total heavy metal in the finished fuel assembly, in both core and axial blanket heavy metal.

1. The fuel design is the General Electric Company Advanced Reactor Systems Department homogeneous reactor reference fuel design.

2. The plant production capacity is $480 \mathrm{t} H M /$ year with the capability for simultaneous production of three enrichments.

3. The plant factor is 240 effective full-production days per year.

4. Plant design capacity:

Overa11

Each line of three
$730 \mathrm{t} \mathrm{HM} /$ year

about 12 fuel assemblies/d

$243 \mathrm{t} \mathrm{HM} /$ year

$0.67 \mathrm{tHM} / \mathrm{d}$

1080 fuel rods/d

4.0 fuel assemblies/d

5. Process design capacities are based on the line design capacities and the scrap and sample losses defined in Sect. 9.13.4.

6. The facilities are designed to discharge no liquid waste other than treated sanitary sewage.

7. All process buildings and critical auxiliary support are designed and constructed in accordance with current United States Nuclear Regulatory Commission licensing requirements. Shielding is provided to limit dose rates to operating and maintenance personnel to $0.25 \mathrm{millirem} / \mathrm{h}$.

In addition, we assumed that production from each fuel rod line is campaigned to provide a full reload segment for a single 1000-MWe LMFBR. 
Thus, the total heavy metal output for a given campaign is $21.1 \mathrm{t}$, and each campaign requires 31.6 effective ful1-production days (48 calendar days). The total facility, with an adjacent radial blanket assembly plant, can support approximately 28 such reactors.

9.13.4 Estimates of Surge Storage Requirements, Scrap Production

Given the plant design assumptions defined in Sect. 9.13.3, further commercial plant characteristics were derived.

To achieve the annual production rates, an analysis of the plant surge storage requirements and normal inventory was made, and the results of this analysis are given in Table 9.54.

Based on current technology and assuming reasonable extrapolations for commercial-scale developments, a preliminary estimate was made of the daily mass flows of heavy metal through the fabrication plant and the average production rate of heavy metal scrap materials from the various functional activities. These are presented in Table 9.55.

Given the above information, a preliminary evaluation of the processing rate for each functional step within the main fuel fabrication processes was made. The results of this analysis are summarized in Table 9.56.

9.13.5 Ana1ysis of Functional Technology Status, Research and Development Requirements, Cost, and Schedule

The technology status of this system is quite similar to that of the reference case discussed in Sect. 8. The current status and research and development needs are summarized in Table 9.57. The primary difference between this $\mathrm{U}-\mathrm{Pu}$ fuel and the reference $\mathrm{U}-\mathrm{Pu}$ fuel is the much higher concentration of plutonium. Development is under way in the United States on sphere forming, calcination, and sintering of ( $\mathrm{U}, \mathrm{Pu})_{2}$ with $\mathrm{Pu} / \mathrm{U}$ ratios adequate for both the reference case and the fast reactor fuels.

While the functional fabrication processes are the same as those given for the reference gel-sphere-pac fabrication case, the design of the 
Table 9.54. Sphere-Pac Fabrication Plant Surge Storage Requirements and Normal Inventory (NASAP Case 6.1, LMFBR U-Pu/U/U Recycle)

\begin{tabular}{|c|c|c|c|c|c|c|}
\hline \multirow{2}{*}{ Process step } & \multirow{2}{*}{ Material } & \multicolumn{2}{|c|}{$\begin{array}{l}\text { Storage } \\
\text { Interva1, d }\end{array}$} & \multicolumn{3}{|c|}{ Norma1 Inventory, $\mathrm{kg} \mathrm{HM}$} \\
\hline & & Normal & Maximum & $(\mathrm{Pu}, \mathrm{U}) \mathrm{O}_{2}$ & $\mathrm{UO}_{2}$ Fines & $\mathrm{UO}_{2}$ Pellets \\
\hline Feed storage & $\begin{array}{l}\text { Dried spheres } \\
\text { Sintered spheres } \\
\text { Sintered pellets }\end{array}$ & $\begin{array}{l}30 \\
30 \\
30\end{array}$ & $\begin{array}{l}60 \\
60 \\
60\end{array}$ & 31,000 & 8,200 & 10,400 \\
\hline Interim storage & $\begin{array}{l}\text { Dried spheres } \\
\text { Sintered spheres } \\
\text { Sintered pellets }\end{array}$ & $\begin{array}{l}1 \\
1 \\
1\end{array}$ & $\begin{array}{l}2 \\
2 \\
2\end{array}$ & 1,030 & 270 & 350 \\
\hline Furnace & $\begin{array}{l}\text { Dried to sintered } \\
\text { spheres }\end{array}$ & 1.2 & 2.4 & 1,240 & & \\
\hline Post Eurnace & Sintered spheres & 0.5 & 1 & 515 & & \\
\hline Interim storage & Sintered spheres & 0.36 & 0.72 & 370 & & \\
\hline Main storage & $\begin{array}{l}\text { Sintered spheres } \\
\text { Sintered spheres } \\
\text { Sintered pellets }\end{array}$ & $\begin{array}{l}1.2 \\
1.5 \\
1.5\end{array}$ & $\begin{array}{l}2.4 \\
2.9 \\
2.9\end{array}$ & 1,300 & 410 & 590 \\
\hline $\begin{array}{l}\text { Loading, inspection, } \\
\text { welding }\end{array}$ & $\begin{array}{l}\text { Sintered spheres } \\
\text { and pellets }\end{array}$ & 0.12 & 0.24 & 130 & 35 & 50 \\
\hline $\begin{array}{l}\text { Loaded, not inspected } \\
\text { rods }\end{array}$ & $\begin{array}{l}\text { Sintered spheres } \\
\text { in rods }\end{array}$ & 5 & 5 & 5,100 & 1,290 & 3,940 \\
\hline Rework and scrap & $\begin{array}{l}\text { Sintered spheres } \\
\text { and pellets }\end{array}$ & 2 & 5 & 250 & 45 & 100 \\
\hline Completed fuel rods & $\begin{array}{l}\text { Sintered spheres } \\
\text { and pellets } \\
\text { in rods }\end{array}$ & 5 & 5 & 4,990 & 1,250 & 3,820 \\
\hline Assembly & $\begin{array}{l}\text { Rods in completed } \\
\text { assemblies }\end{array}$ & 15 & 30 & 15,000 & 3,740 & 11,400 \\
\hline
\end{tabular}


Table 9.55. Heavy Metal Mass Flows and Average Scrap Production for a Sphere-Pac Fuel Fabrication Plant (NASAP Case 6.1 , IMFBR U - Pu/U/U Recycle)

\begin{tabular}{|c|c|c|c|c|c|c|c|c|c|c|}
\hline \multirow{3}{*}{ Processing Step } & \multicolumn{10}{|c|}{ Mass Flow, $\mathrm{kg}$ tM/d } \\
\hline & \multicolumn{3}{|c|}{ Daily Throughput } & \multicolumn{3}{|c|}{ Clean Scrap ${ }^{b}$} & \multicolumn{4}{|c|}{ Reject Scrap ${ }^{c}$} \\
\hline & $(\mathrm{Pu}, \mathrm{U}) \mathrm{O}_{2}^{a}$ & $\begin{array}{l}\mathrm{UO}_{2} \\
\text { F1nes }\end{array}$ & $\begin{array}{c}\text { Axtal Blanket } \\
\mathrm{UO}_{2} \text { Pellets }\end{array}$ & $(\mathrm{Pu}, \mathrm{v}) \mathrm{O}_{2}{ }^{a}$ & $\begin{array}{l}\mathrm{UO}_{2} \\
\text { Fines }\end{array}$ & $\begin{array}{l}\text { Axial Blanket } \\
\mathrm{UO}_{2} \text { Pellets }\end{array}$ & $(\mathrm{Pu}, \mathrm{U}) \mathrm{O}_{2}$ & $\begin{array}{l}\mathrm{UO}_{2} \\
\text { Fines }\end{array}$ & $\begin{array}{c}\text { Axial } \\
\mathrm{NO}_{2}\end{array}$ & $\begin{array}{l}1 \text { Blanket } \\
\text { Pellets }\end{array}$ \\
\hline Receiving and storage & 1031.2 & $271.6^{d}$ & 762.2 & & & & & & & \\
\hline Sampling and batch loading & 1030.2 & & & & & & 1.0 & & & \\
\hline Welghing and sampling & & 271.3 & $761.5^{e}$ & & & & & 0.2 & & 0.8 \\
\hline Calcining and sintering & 1029.7 & & & & & & 0.5 & & & \\
\hline Sphere upgrading & $1087.6^{f}$ & & & & & & 30.9 & & & \\
\hline Sphere sampling & 1085.4 & & & & & & 2.2 & & & \\
\hline Interim storage & 1085.4 & 271.3 & 415.1 & & & & & & & \\
\hline Fuel rod loading & 1085.4 & 271.3 & 415.1 & & & & & & & \\
\hline Fuel rod scanning & 1031.1 & 257.8 & $788.7^{\theta}$ & 52.1 & 13.0 & 19.9 & 2.2 & 0.5 & & 0.8 \\
\hline Top component insertion & 1028.9 & 257.2 & 787.0 & 2.1 & 0.5 & 1.6 & 0.2 & 0.1 & & 0.2 \\
\hline Rod welding and $x$ ray & 1028.9 & 257.2 & 787.0 & $h$ & $h$ & n & h & $h$ & & $h$ \\
\hline Leak detection & 1028.9 & 257.2 & 787.0 & $h$ & $h$ & h & $h$ & $h$ & & $h$ \\
\hline Rod assay & 1008.3 & 252.1 & 771.2 & 19.5 & 4.9 & 15.0 & 1.0 & 0.3 & & 0.8 \\
\hline Final rod inspection & 997.8 & 249.4 & 763.2 & 10.1 & 2.5 & 7.7 & 0.4 & 0.1 & & 0.3 \\
\hline Assembly inspection & 992.6 & 248.2 & 759.2 & 5.0 & 1.2 & 3.8 & 0.2 & 0.05 & & $\underline{0.2}$ \\
\hline Total & & 2000 & & 88.8 & 22.1 & 48.0 & 38.6 & 1.3 & & 3.1 \\
\hline
\end{tabular}

$a_{10.24}$ and $14.36 \%$ average fissile plutonium content in zones 1 and 2 , respectively.

binternally recycled.

${ }^{c}$ Collected, assayed, and externally recycled to reprocessing plant.

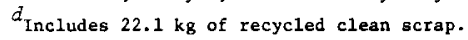

$346.4 \mathrm{~kg}$ reserved for upper axial blanket loading (after fuel rod scanning).

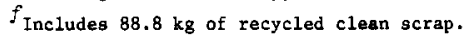

${ }^{g}$ Includes $48.0 \mathrm{~kg}$ of recycled clean scrap and $346.4 \mathrm{~kg}$ of fresh material.

$h_{\text {Rework }}$ in these steps is only of weld and does not affect scrap. 
Table 9.56. Equipment Requirements for Functional Areas (NASAP Case 6.I LMFBR U-Pu/U/U Recycle)

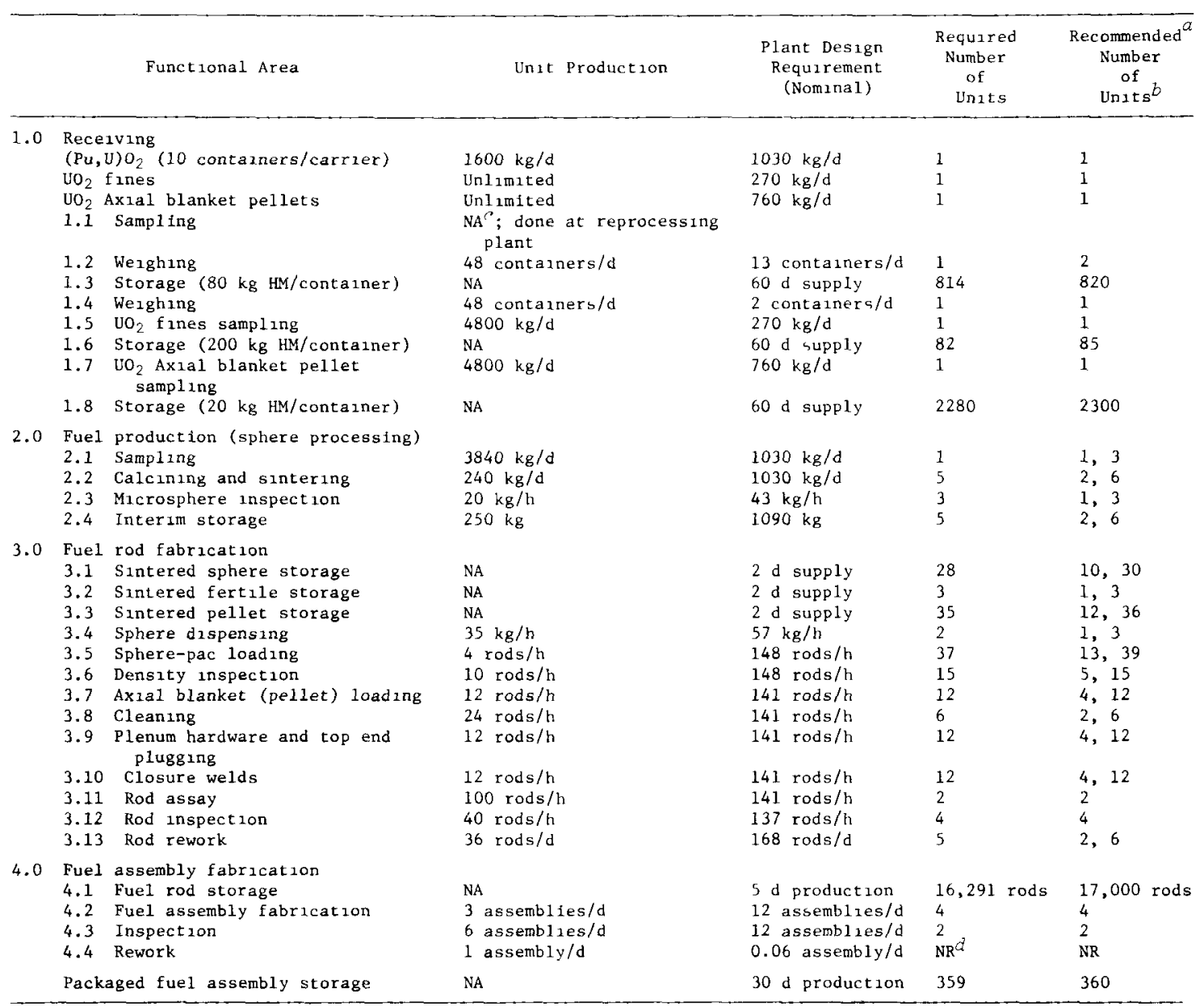

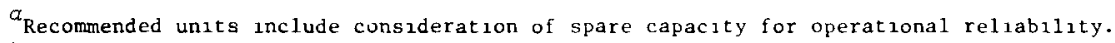

$b$ Number of units is for the facility if a single number; otherwise, units per line, total units in facility.

cNA: not applicable.

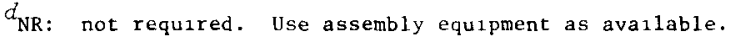


Table 9.57. Research and Development Cost Estimates for Sphere-Pac Fabrication [NASAP Case 6.1, LMFBR U-Pu/U Recycle (GE Reference)]

\begin{tabular}{|c|c|c|c|c|}
\hline & R\&D Categories & Current status ${ }^{\alpha}$ & $\begin{array}{l}\text { R\&D Cost Estimates } \\
\text { (Millions of } \\
1978 \$)\end{array}$ & $\begin{array}{l}\text { Years to } \\
\text { Complete }\end{array}$ \\
\hline 1.0 & Program management & Not applicable & 10 & 10 \\
\hline 2.0 & Design studies & $\mathrm{N}$ - cold engineering & 25 & 10 \\
\hline 3.0 & Receiving and storage & $P$ - cold engineering & 4 & 5 \\
\hline 4.0 & Fuel production & $P$ - hot engineering & 25 & 6 \\
\hline 5.0 & Fuel rod fabrication & $P$ - cold laboratory & 50 & 8 \\
\hline 6.0 & Fuel element assembly & $\mathrm{N}-$ cold engineering & 27 & 8 \\
\hline 7.0 & Scrap recovery & $\mathrm{N}-$ cold engineering & 3 & 5 \\
\hline 8.0 & Waste treatment & $b$ & $b$ & $b$ \\
\hline 9.0 & Plant control systems & $\mathrm{N}-$ cold prototype & 5 & 8 \\
\hline 10.0 & Maintenance & $\mathrm{N}-\operatorname{cold}$ prototype & 5 & 10 \\
\hline 11.0 & $\begin{array}{l}\text { Safeguards and account- } \\
\text { ability adaptation }\end{array}$ & $P$ - cold engineering & 6 & 6 \\
\hline & Subtotal & & 160 & \\
\hline \multicolumn{5}{|c|}{ Special Facilities } \\
\hline \multicolumn{2}{|c|}{ Hot tests } & & 10 & \\
\hline \multicolumn{2}{|c|}{ Cold prototype } & & 25 & \\
\hline \multicolumn{2}{|r|}{ Total } & & $195^{d}$ & \\
\hline \multicolumn{2}{|r|}{ Range } & & $185-235$ & \\
\hline $\begin{array}{l}\mathrm{N}=\mathrm{n} \\
\text { appli } \\
\mathrm{mi1} 11\end{array}$ & $\begin{array}{l}a_{\text {Status stage with qualit }} \\
\text { eeded. } \\
b_{\text {To be supplied by others }} \\
c_{\text {Assumes basic technology }} \\
\text { cations testing, systems } \\
d_{\text {The estimate does not in }} \\
\text { on) or the capital costs }\end{array}$ & $\begin{array}{l}\text { ive modifiers; } c=\text { cor } \\
\text { s developed under oss } \\
\text { tegration, and testin } \\
\text { ude costs for fuel que } \\
\text { a pilot plant estimat }\end{array}$ & $\begin{array}{l}\text { lete, } P=\text { in progre } \\
\text { stimate presented } \\
\text { ification tests }(\mathrm{ab} \\
\mathrm{d} \text { at } \$ 160 \text { million. }\end{array}$ & $\begin{array}{l}s \text {, and } \\
\text { for } \\
\text { ut } \$ 20\end{array}$ \\
\hline
\end{tabular}


LMFBR fuel elements is considerably different. These differences in design result in modifications to the details for accomplishing the various functional activities and modifications to the facility design details. In the subsequent paragraphs, each of the functional activities is discussed as it applies to this case.

A generic gel-sphere-pac functional flow diagram is given in Fig. 3.1 of Sect. 3.1.1 of this report. The major functional areas apply to this case, and the two main functions unique to the gel-sphere-pac process are fuel production (2.0) and fuel rod fabrication (3.0). All the functional steps are briefly discussed here.

Receiving and Storage. This functional area is quite similar to the reference case. However, in addition to the spheres, the $\mathrm{UO}_{2}$ pellets from the adjacent radial blanket assembly plant must be received, inspected, and stored.

Fuel Production. The fuel production processes for the spheres are essentially the same as those described for the reference case including calcination, sintering, and inspection of the coarse and medium sizes, which contain plutonium. No processing is planned for the $\mathrm{UO}_{2}$ fines because they are to be sintered at the reprocessing conversion step. However, because the $\mathrm{UO}_{2}$ axial blanket pellets make up approximately $38 \%$ of the total heavy metal content in a core fuel assembly, the quantity of coarse and medium spheres processed is significantly less than in the reference case.

Fue1 Rod Fabrication. While most of the fuel rod fabrication processes are similar to the reference case, additional steps are required to incorporate the axial blanket material. The lower axial blanket section is loaded into the fuel rod cladding before the cladding is introduced into the cell. After the $(\mathrm{U}, \mathrm{Pu}) \mathrm{O}_{2}$ core region is loaded by the sphere-pac process into each rod and inspected for density the upper axial blanket section will be loaded by equipment similar to that used for inserting plenum hardware. The actual plenum hardware insertion and end cap welding operations are essentially the same as those described for the reference case.

Fuel Assembly Operations. The fuel assembly design for this LMFBR case 6.1 is identical to that for the pellet fabrication option. 
Following fuel rod inspection each rod will be remotely wrapped with a wire. This special wire wrap will space the fuel rods in the assembly. Groups of these rods are assembled onto T-bars of varying length. The T-bar strip layers are assembled and fastened to the lower end box of the fuel assemb1y. The duct tube is installed and the finished assembly is inspected.

Product Control Processes. These are the same as the reference case (see Sect. 4.1.2).

Scrap and Waste Processing and Disposal. The scrap handling processes are similar to the reference case (see Sect.4.1.2) with the added feature that all axial blanket pellets that are unloaded from an unsatisfactory rod are inspected, and acceptable pellets are recycled within the remotely operated part of the facilities to form upper axial blankets.

\subsubsection{Preliminary Cost Estimate for Construction and Operation of a Commercia1-Scale Plant}

The cost components that were estimated include capital costs for the facility and equipment, fuel assembly hardware costs, material and supply costs, and operating costs.

Facility capital cost estimates were based on an analysis of the functional flow diagram for the process to indicate space requirements for each functional area and for each support area. Equipment requirements were identified, and costs associated with the equipment were estimated. Fuel assembly hardware requirements were based on the reference fuel assembly design parameters identified in Table 9.53. Estimates of the costs of the hardware items were obtained. Material and supply requirements were identified from the sphere-pac process description, and estimates of the costs of materials and supplies were obtained. Operating cost estimates included consideration of personnel, overhead, general and administrative expenses, and costs of utilities.

The facility was assumed to operate as a toll processing facility. That 1s, the operator fabricates customer-supplied fuel feed materials into finished fuel assemblies, and thus costs of plutonium and uranium 
were not included in the cost estimates. The hardware and material costs do include the costs associated with the production of the $\mathrm{UO}_{2}$ pellets for the axial blanket.

Unit costs for fabrication of fuel assemblies are determined by an economic analysis of the basic capital, hardware and material, and operating cost estimates. Basically, the economic analysis provides for the owner of the fuel fabrication facility to recover all capital, operating, and finance charges plus a return on investment, if appropriate, over the life of the plant.

In order to provide a range of prices (i.e., costs to a customer), economic analyses were based on government financing, financing appropriate for a conventional-risk (typical) industry, and financing appropriate for a high-risk industry. ${ }^{2}$ The estimated costs, costs derived from the economic analysis, and the unit costs based on the three different financing methods are summarized in Table 9.58. As may be observed from the table, the price for fabrication of $(\mathrm{U}, \mathrm{Pu})_{2}-\mathrm{UO}_{2}$ fuel is expected to be in the range from $\$ 380$ to $\$ 730 / \mathrm{kg}$ depending on the financing technique that is employed. The recommended cost for comparison with other fuel cycles and methods of fabrication is the typical industry cost of $\$ 580 / \mathrm{kg}$ of heavy metal. As with all the cost estimates in this report, the prices are based on the mass of all heavy metal in the finished assembly. For this case, this includes the uranium in the axial blankets. 
Table 9.58. Summary of Costs for Fabrication of Sphere-Pac PWR Fuel in a 2-t HM/d Facility (NASAP Case 6.1 LMFBR U-Pu/U/U Recycle)

\begin{tabular}{|c|c|c|c|c|c|c|c|c|c|}
\hline \multirow[b]{2}{*}{$\begin{array}{l}\text { Economic } \\
\text { Set }^{a}\end{array}$} & \multicolumn{4}{|c|}{ Estimated Costs, \$ million } & \multicolumn{4}{|c|}{ Derived Costs, \$ million } & \multirow[b]{2}{*}{$\begin{array}{l}\text { Unit } \\
\text { Cost } \\
(\$ / \mathrm{kg})\end{array}$} \\
\hline & Facility & Equipment & $\begin{array}{c}\text { Annual } \\
\text { Hardware } \\
\text { Plus } \\
\text { Materials }\end{array}$ & $\begin{array}{c}\text { Annual } \\
\text { Operating }\end{array}$ & $\begin{array}{l}\text { Owner's } \\
\text { Cost } \\
\text { During } \\
\text { Construction }\end{array}$ & $\begin{array}{c}\text { Charge on } \\
\text { Direct Capital } \\
\text { During } \\
\text { Construction }\end{array}$ & $\begin{array}{c}\text { Annual } \\
\text { Equipment } \\
\text { Replacement } \\
\text { Cost }\end{array}$ & $\begin{array}{l}\text { Annual } \\
\text { Payment to } \\
\text { Decommissioning } \\
\text { Fund }\end{array}$ & \\
\hline A & 260 & 255 & 66 & 27 & 39 & 140 & 13 & 1.2 & 380 \\
\hline B & 260 & 255 & 66 & 28 & 41 & 200 & 13 & 1.3 & 580 \\
\hline C & 260 & 255 & 66 & 29 & 42 & 200 & 13 & 1.3 & 730 \\
\hline
\end{tabular}

$a_{\mathrm{A}}=$ Government financing; $\mathrm{B}=$ Typical industrial financing; $\mathrm{c}=$ High-risk industrial financing.

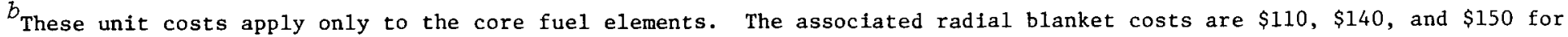
economic sets $A, B$, and $C$, respectively. 


\subsection{NASAP CASE 6.2.1, LMFBR U-Pu/U SPIKED RECYCLE (WESTINGHOUSE REFERENCE) - HETEROGENEOUS CORE DESIGN}

\subsubsection{Fuel Cycle Description}

This reactor-fuel cycle combination is an LMFBR using $14.3 \%$ fissile assay mixed $\mathrm{U}-\mathrm{Pu}$ recycle fuel in the core and depleted uranium in the blanket assemblies. The core and blanket assemblies are reprocessed separately. The core is coprocessed, and all the recovered $\mathrm{U}-\mathrm{Pu}$ is mixed with a portion of the $U-P u$ recovered during blanket reprocessing to provide feed material to core fabrication. The excess U-Pu recovered during blanket reprocessing is sent to secure storage; it will be preirradiated before shipment or sale. The balance of the uranium recovered during reprocessing is mixed with makeup uranium to provide feed material for blanket fabrication.

In this cycle analysis only fabrication of the core assemblies is considered. The products of the reprocessing plant are highly decontaminated and include the coarse and medium sizes of spherical particles with the appropriate uranium-plutonium ratio and the recycled $\mathrm{UO}_{2}$ fines. Spiking is provided after fabrication by irradiation. The assumption was that excess uranium from the reprocessing plant and/or makeup depleted uranium will be fabricated by the pellet process into radial blanket assemblies in an adjacent contact-operated and contact-maintained (CO/CM) facility. Urania pellets from that adjacent facility will be used in the core fabrication facility for the axial blankets in the core assemblies.

The extended burnup of the recycle plutonium will cause this material to have significant radioactivity; consequently, a remotely operated and contact-maintained ( $R O / C M$ ) facility is required for the core assemblies for this cycle.

\subsubsection{Applicability to Current Fuel Element Design}

The core fuel element design chosen for this cycle is given in Table 9.59.

The key considerations for sphere-pac applicability are the cladding inside diameter measurements and the required fuel smear density. The 
Table 9.59. Summary of Westinghouse Large Pin Reference LMFBR Fue1 Assemb1y Parameters

(NASAP Case 6.2.1, LMFBR U-Pu/U Spiked Recycle)

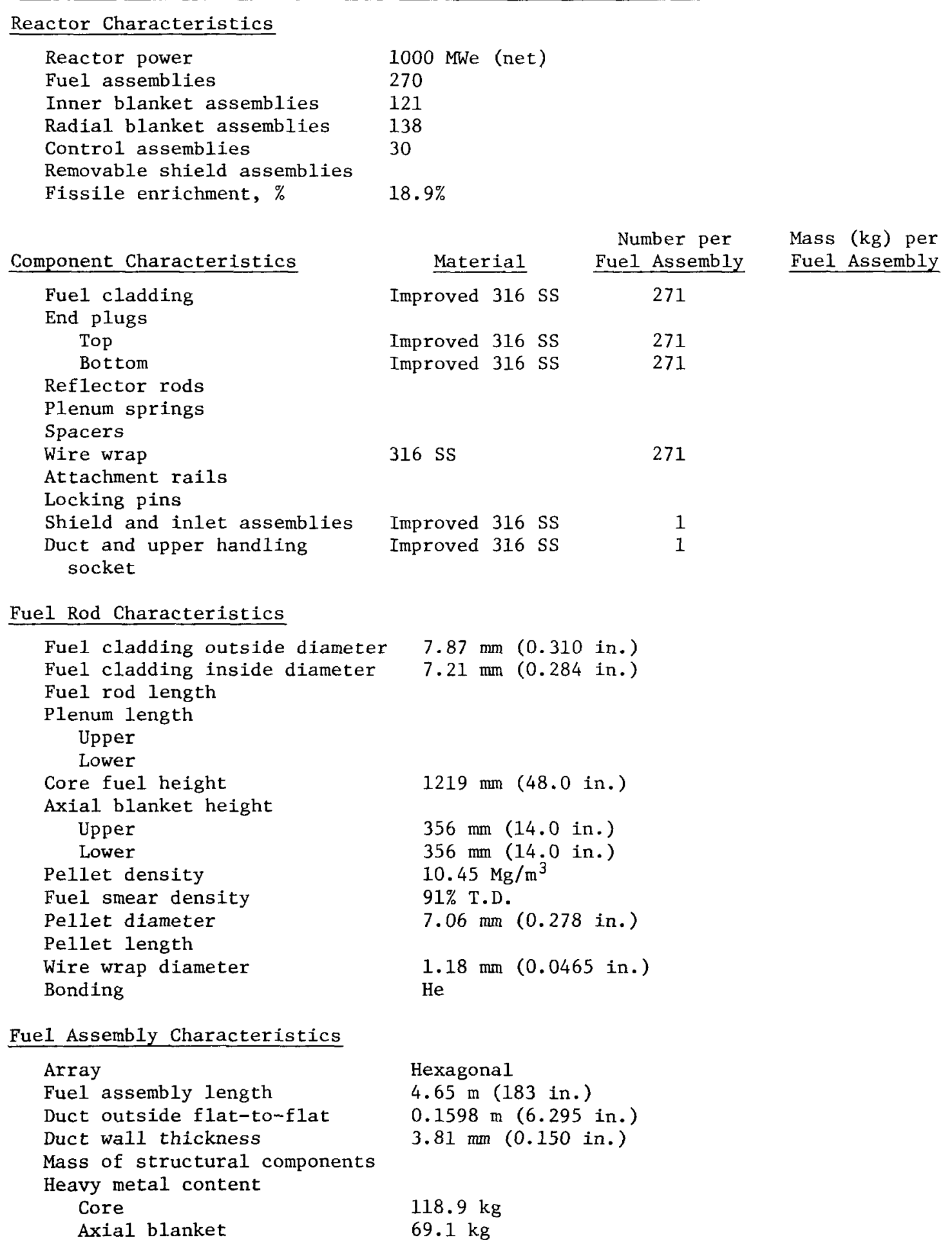


cladding ID of $7210 \mu \mathrm{m}$ in the reference design is suitable for the spherepac process. Although the specified smear density of $91 \%$ of theoretical is above that currently achieved with experimental blended (three particle size) sphere-pac beds, we have assumed that the process is applicable through a slight lowering of this design requirement.

\subsubsection{Definition of Plant Production Requirements and Design Capacity}

For this $\mathrm{LMFBR}(\mathrm{U}, \mathrm{Pu}) \mathrm{O}_{2}-\mathrm{UO}_{2}$ fuel cycle, the plant design assumptions are listed below. The heavy metal through-put for this plant and all cases involving axial blanket fuel is based on the total heavy metal in the finished fuel assembly, in both core and axial blanket heavy metal.

1. The fuel design is the Westinghouse Electric Corporation Advanced Reactors Division heterogeneous core reactor reference large rod fuel design.

2. The plant production capacity is $480 \mathrm{t} \mathrm{HM} / \mathrm{year}$ with the capability for simultaneous production of three enrichments.

3. The plant factor is 240 effective full-production days per year.

4. Plant design capacity: Overal1 $730 \mathrm{t} \mathrm{HM} /$ year about 11 fuel assemblies/d Each line of three $243 \mathrm{t} \mathrm{HM} /$ year $0.67 \mathrm{t} \mathrm{HM} / \mathrm{d}$

961 fuel rods/d

3.5 fuel assemblies/d

5. Process design capacities are based on the line design capacities and the scrap and sample losses defined in Sect. 9.14.4.

6. The facilities are designed to discharge no liquid waste other than treated sanitary sewage.

7. All process buildings and critical auxiliary support are designed and constructed in accordance with current United States Nuclear Regulatory Commission licensing requirements. Shielding is provided to limit dose rates to operating and maintenance personnel to $0.25 \mathrm{millirem} / \mathrm{h}$.

In addition, we assumed that production from each fuel rod line is campaigned to provide a full reload segment for a single 1000-MWe LMFBR. 
Thus, the total heavy metal output for a given campaign is $17 t$, and each campaign requires 25.4 effective ful1-production days ( 39 calendar days). The total facility, with an adjacent radial blanket assembly plant, can support approximately 28 such reactors.

\subsubsection{Estimates of Surge Storage Requirements, Scrap Production Rates, and Processing Rates for Functional Steps}

Given the plant design assumptions defined in Sect.9.14.3, further commercial plant characteristics were derived.

To achieve the annual production rates, an analysis of the plant surge storage requirements and normal inventory was made, and the results of this analysis are given in Table 9.60.

Based on current technology and assuming reasonable extrapolations for commercial-scale developments, preliminary estimates were made of the daily mass flows of heavy metal through the fabrication plant and the average production rate of heavy metal scrap materials from the various functional activities. These are presented in Table 9.61.

Given the above information, a preliminary evaluation of the processing rate for each functional step within the main fuel fabrication processes was made. The results of this analysis are summarized in Table 9.62.

\subsubsection{Analysis of Functional Technology Status, Research and Development Requirements, Cost, and Schedule}

The technology status of this system is quite similar to that of the reference case discussed in Sect. 8. The current status and research and development needs are summarized in Table 9.63. The primary difference between this $\mathrm{U}-\mathrm{Pu}$ fuel and the reference $\mathrm{U}-\mathrm{Pu}$ fuel is the much higher concentration of plutonium. Development is under way in the United States on sphere forming, calcination, and sintering of $(\mathrm{U}, \mathrm{Pu}) \mathrm{O}_{2}$ with $\mathrm{Pu} / \mathrm{U}$ ratios adequate for both the reference case and the fast reactor fuels.

While the functional fabrication processes are the same as those given for the reference gel-sphere-pac fabrication case, the design of the 
Table 9.60. Sphere-Pac Fabrication Plant Surge Storage Requirements and Normal Inventory (NASAP Case 6.2.1, LMFBR U-Pu/U Spiked Recycle, Westinghouse Reference)

\begin{tabular}{|c|c|c|c|c|c|c|}
\hline \multirow{2}{*}{ Process step } & \multirow{2}{*}{ Material } & \multicolumn{2}{|c|}{$\begin{array}{c}\text { Storage } \\
\text { Interval, } \mathrm{d}\end{array}$} & \multicolumn{3}{|c|}{ Normal Inventory, $\mathrm{kg} \mathrm{HM}$} \\
\hline & & Normal & Maximum & $(\mathrm{Pu}, \mathrm{U}) \mathrm{O}_{2}$ & $\mathrm{UO}_{2}$ Fines & $\mathrm{UO}_{2}$ Pellets \\
\hline Feed storage & $\begin{array}{l}\text { Dried spheres } \\
\text { Sintered spheres } \\
\text { Sintered pellets }\end{array}$ & $\begin{array}{l}30 \\
30 \\
30\end{array}$ & $\begin{array}{l}60 \\
60 \\
60\end{array}$ & 32,000 & 8,300 & 10,100 \\
\hline Interim storage & $\begin{array}{l}\text { Dried spheres } \\
\text { Sintered spheres } \\
\text { Sintered pellets }\end{array}$ & $\begin{array}{l}1 \\
1 \\
1\end{array}$ & $\begin{array}{l}2 \\
2 \\
2\end{array}$ & 1,100 & 280 & 340 \\
\hline Furnace & $\begin{array}{l}\text { Dried to sintered } \\
\text { spheres }\end{array}$ & 1.2 & 2.4 & 1,260 & & \\
\hline Post furnace & Sintered spheres & 0.5 & 1 & 1,530 & & \\
\hline Interim storage & Sintered spheres & 0.36 & 0.72 & 380 & & \\
\hline Main storage & $\begin{array}{l}\text { Sintered spheres } \\
\text { Sintered spheres } \\
\text { Sintered pellets }\end{array}$ & $\begin{array}{l}1.2 \\
1.5 \\
1.5\end{array}$ & $\begin{array}{l}2.4 \\
2.9 \\
2.9\end{array}$ & 1,300 & 410 & 570 \\
\hline $\begin{array}{l}\text { Loading, inspection, } \\
\text { welding }\end{array}$ & $\begin{array}{l}\text { Sintered spheres } \\
\text { and pellets }\end{array}$ & 0.12 & 0.24 & 130 & 35 & 45 \\
\hline $\begin{array}{l}\text { Loaded, not inspected } \\
\text { rods }\end{array}$ & $\begin{array}{l}\text { Sintered spheres } \\
\text { in rods }\end{array}$ & 5 & 5 & 5,200 & 1,310 & 3,810 \\
\hline Rework and scrap & $\begin{array}{l}\text { Sintered spheres } \\
\text { and pellets }\end{array}$ & 2 & 5 & 260 & 50 & 100 \\
\hline Completed fuel rods & $\begin{array}{l}\text { Sintered spheres } \\
\text { and pellets } \\
\text { in rods }\end{array}$ & 5 & 5 & 5,100 & 1,270 & 3,690 \\
\hline Assembly & $\begin{array}{l}\text { Rods in completed } \\
\text { assemblies }\end{array}$ & 15 & 30 & 15,000 & 3,810 & 11,100 \\
\hline
\end{tabular}




\begin{tabular}{|c|c|c|c|c|c|c|c|c|c|}
\hline \multirow{3}{*}{ Processing Step } & \multicolumn{9}{|c|}{ Mass Flow, $\mathrm{kg}$ HM $/ \mathrm{d}$} \\
\hline & \multicolumn{3}{|c|}{ Dally Throughput } & \multicolumn{3}{|c|}{ Clean Scrap $b$} & \multicolumn{3}{|c|}{ Reject Scrap ${ }^{c}$} \\
\hline & $(\mathrm{Pu}, \mathrm{U}) \mathrm{O}_{2}{ }^{\alpha}$ & $\begin{array}{c}\mathrm{UO}_{2} \\
\text { Fines }\end{array}$ & $\begin{array}{l}\mathrm{Ax} 1 \mathrm{al} \text { Blanket } \\
\mathrm{UO}_{2} \text { Pellets }\end{array}$ & $(\mathrm{Pu}, \mathrm{U}) \mathrm{O}_{2} \mathrm{a}$ & $\begin{array}{c}\mathrm{uO}_{2} \\
\text { Fines }\end{array}$ & $\begin{array}{l}\text { Axial Blanket } \\
\text { UO, Pellets }\end{array}$ & $(\mathrm{Pu}, \mathrm{U}) \mathrm{O}_{2}$ & $\begin{array}{c}\mathrm{UO}_{2} \\
\text { Fines }\end{array}$ & $\begin{array}{l}\text { Axial Blanket } \\
\text { U0 }{ }_{<} \text {Pellets }\end{array}$ \\
\hline Receiving and storage & 1051.3 & $276.9^{d}$ & 737.9 & & & & & & \\
\hline Sampling and batch loading & 1050.2 & & & & & & 1.1 & & \\
\hline Weighing and sampling & & 276.6 & $737.2^{e}$ & & & & & 03 & 07 \\
\hline Calcining and sintering & 1049.7 & & & & & & 0.5 & & \\
\hline Sphere upgrading & $1108.7^{f}$ & & & & & & 31.5 & & \\
\hline Sphere sampling & 1106.5 & & & & & & 2.2 & & \\
\hline Interim storage & 1106.5 & 276.6 & 4019 & & & & & & \\
\hline Fuel rod loading & 1106.5 & 276.6 & 401.9 & & & & & & \\
\hline Fuel rod scannzng & 1051.2 & 262.8 & $763.6^{9}$ & 53.1 & 133 & 19.3 & 22 & 0.6 & 08 \\
\hline Top component insertion & 1048.9 & 262.2 & 762.0 & 2.1 & 0.5 & 15 & 0.2 & 0.1 & 0.2 \\
\hline Rod welding and $x$ ray & 1048.9 & 262.2 & 762.0 & $n$ & $n$ & n & h & $h$ & $h$ \\
\hline Leak detection & 1048.9 & 262.2 & 762.0 & i & $h$ & $n$ & h & $h$ & h \\
\hline Rod assay & 1027.9 & 257.0 & 746.7 & 19.9 & 5.0 & 14.5 & 10 & 0.3 & 08 \\
\hline Final rod inspection & 1017.2 & 254.3 & 738.9 & 10.3 & 2.6 & 7.5 & 0.4 & 0.1 & 0.3 \\
\hline Assembly inspection & 1011.9 & 253.0 & 735.1 & 51 & 1.3 & 3.7 & 0.2 & 0.1 & 0.1 \\
\hline Tota1 & & 2000 & & 90.5 & 22.7 & 46.5 & 39.3 & 1.3 & 2.9 \\
\hline
\end{tabular}

$a_{18.9 \%}$ average fissile plutonium content.

$b_{\text {Interna11y recycled. }}$

${ }^{c}$ Collected, assayed, and externally recycled to reprocessing plant.

$d_{\text {Includes } 22.7 \mathrm{~kg} \text { of recycled clean scrap. }}$.

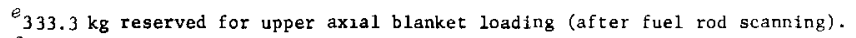

$f_{\text {Includes } 22.7 \mathrm{~kg} \text { of recycled clean scrap. }}$.

$g^{g}$ Includes $48.0 \mathrm{~kg}$ of recycled clean scrap and $346.4 \mathrm{~kg}$ of fresh mater1al for upper axial blanket loading.

$h_{\text {Rework }}$ in these steps 1 only of weld and does not af fect scrap. 
Table 9.62. Equipment Requirements for Functional Areas

[NASAP Case 6.2.1, LMFBR U-Pu/U Spiked Recycle

(Westinghouse Reference) - Heterogeneous Core Design]

\begin{tabular}{|c|c|c|c|c|c|}
\hline & Functional Area & Unit Production & $\begin{array}{l}\text { Plant Design } \\
\text { Requirement } \\
\text { (Nomina1) }\end{array}$ & $\begin{array}{l}\text { Required } \\
\text { Number } \\
\text { of } \\
\text { Units }\end{array}$ & $\begin{array}{c}\text { Recommended } \\
\text { Number } \\
\text { of } \\
\text { Units }\end{array}$ \\
\hline 1.0 & $\begin{array}{l}\text { Recelving } \\
\text { (Pu,U) } \mathrm{O}_{2} \text { ( } 10 \text { containers/carrier) } \\
\mathrm{UO}_{2} \text { flnes } \\
\mathrm{UO}_{2} \text { Axial blanket pellets } \\
1.1 \text { Sampling }\end{array}$ & $\begin{array}{l}1600 \mathrm{~kg} / \mathrm{d} \\
\text { Unl imited } \\
\text { Unlimited } \\
\mathrm{NA}^{\mathrm{C}} \text {, done at reprocessing } \\
\text { plant }\end{array}$ & $\begin{array}{l}1050 \mathrm{~kg} / \mathrm{d} \\
280 \mathrm{~kg} / \mathrm{d} \\
740 \mathrm{~kg} / \mathrm{d}\end{array}$ & $\begin{array}{l}1 \\
1 \\
1\end{array}$ & $\begin{array}{l}1 \\
1 \\
1\end{array}$ \\
\hline & $\begin{array}{l}1.2 \text { Welghing } \\
1.3 \text { Storage ( } 80 \mathrm{~kg} \mathrm{HM} / \text { contalner) } \\
1.4 \text { Welghing } \\
1.5 \text { UO }{ }_{2} \text { fines sampling } \\
1.6 \text { Storage ( } 200 \mathrm{~kg} \mathrm{HM} / \text { container) } \\
1.7 \text { UO } \mathrm{U}_{2} \text { Axial blanket pellet } \\
\text { sampling }\end{array}$ & $\begin{array}{l}48 \text { containers/d } \\
\mathrm{NA} \\
48 \text { contanners } / \mathrm{d} \\
4800 \mathrm{~kg} / \mathrm{d} \\
\mathrm{NA} \\
4800 \mathrm{~kg} / \mathrm{d}\end{array}$ & $\begin{array}{l}14 \text { containers } / \mathrm{d} \\
60 \mathrm{~d} \text { supply } \\
2 \mathrm{contalners} / \mathrm{d} \\
280 \mathrm{~kg} / \mathrm{d} \\
60 \mathrm{~d} \text { supply }\end{array}$ & $\begin{array}{l}1 \\
789 \\
1 \\
1 \\
84\end{array}$ & $\begin{array}{l}2 \\
800 \\
1 \\
1 \\
85\end{array}$ \\
\hline 2.0 & $\begin{array}{l}\text { Fuel production (sphere processing) } \\
2.1 \text { Sampling } \\
2.2 \text { Calcining and sintering } \\
2.3 \text { Microsphere inspection } \\
2.4 \text { Interim storage }\end{array}$ & $\begin{array}{l}3840 \mathrm{~kg} / \mathrm{d} \\
240 \mathrm{~kg} / \mathrm{d} \\
20 \mathrm{~kg} / \mathrm{h} \\
250 \mathrm{~kg}\end{array}$ & $\begin{array}{l}1050 \mathrm{~kg} / \mathrm{d} \\
1050 \mathrm{~kg} / \mathrm{d} \\
46 \mathrm{~kg} / \mathrm{h} \\
1110 \mathrm{~kg}\end{array}$ & $\begin{array}{l}1 \\
5 \\
3 \\
5\end{array}$ & $\begin{array}{ll}1, & 3 \\
2, & 6 \\
1, & 3 \\
2, & 6\end{array}$ \\
\hline 3.0 & $\begin{array}{l}\text { Fuel rod fabrication } \\
3.1 \text { Sintered sphere storage } \\
3.2 \text { Sintered fertile storage } \\
3.3 \text { Sintered pellet storage } \\
3.4 \text { Sphere dispensing } \\
3.5 \text { Sphere-pac loading } \\
3.6 \text { Density inspection } \\
3.7 \text { Axial blanket (pellet) loading } \\
3.8 \text { Cleaning } \\
3.9 \text { Plenum hardware and top end } \\
3.10 \text { Plogging } \\
3.11 \text { Rod assay } \\
3.12 \text { Rod inspection } \\
3.13 \text { Rod rework }\end{array}$ & $\begin{array}{l}\mathrm{NA} \\
\mathrm{NA} \\
\mathrm{NA} \\
35 \mathrm{~kg} / \mathrm{h} \\
4 \mathrm{rods} / \mathrm{h} \\
10 \mathrm{rods} / \mathrm{h} \\
12 \mathrm{rods} / \mathrm{h} \\
24 \mathrm{rods} / \mathrm{h} \\
12 \mathrm{rods} / \mathrm{h} \\
12 \mathrm{rods} / \mathrm{h} \\
100 \mathrm{rods} / \mathrm{h} \\
40 \mathrm{rods} / \mathrm{h} \\
36 \mathrm{rods} / \mathrm{d}\end{array}$ & $\begin{array}{l}2 \mathrm{~d} \text { supply } \\
2 \mathrm{~d} \text { supply } \\
2 \mathrm{~d} \text { supply } \\
58 \mathrm{~kg} / \mathrm{h} \\
132 \mathrm{rods} / \mathrm{h} \\
132 \mathrm{rods} / \mathrm{h} \\
125 \mathrm{rods} / \mathrm{h} \\
125 \mathrm{rods} / \mathrm{h} \\
125 \mathrm{rods} / \mathrm{h}\end{array}$ & $\begin{array}{l}28 \\
3 \\
39 \\
2 \\
33 \\
14 \\
11 \\
6 \\
11 \\
11 \\
2 \\
4 \\
5\end{array}$ & $\begin{array}{l}10,30 \\
1,3 \\
13,39 \\
1,3 \\
11,33 \\
5,15 \\
4,12 \\
2,6 \\
4,12 \\
4,12 \\
2 \\
4 \\
2,6\end{array}$ \\
\hline 4.0 & $\begin{array}{l}\text { Fuel assembly fabrication } \\
4.1 \text { Fuel rod storage } \\
4.2 \text { Fuel assembly fabrication } \\
4.3 \text { Inspection } \\
4.4 \text { Rework }\end{array}$ & $\begin{array}{l}\text { NA } \\
3 \text { assemblies/d } \\
6 \text { assemblies } / d \\
1 \text { assembly/d }\end{array}$ & $\begin{array}{l}5 \mathrm{~d} \text { production } \\
11 \mathrm{assemb} l i e s / \mathrm{d} \\
11 \mathrm{assemblies} / \mathrm{d} \\
0.05 \mathrm{assembly} / \mathrm{d}\end{array}$ & $\begin{array}{l}14,490 \mathrm{rods} \\
4 \\
2 \\
\mathrm{NR}^{d}\end{array}$ & $\begin{array}{l}15,000 \text { rods } \\
4 \\
2 \\
\text { NR }\end{array}$ \\
\hline & Packaged fuel assembly storage & NA & $30 \mathrm{~d}$ production & 320 & 320 \\
\hline
\end{tabular}

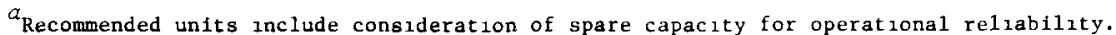

$b$ Number of units is for the facility if a single number, otherwise, units per line, total units in facility.

cNA: not applicable.

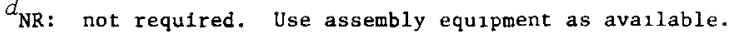


Table 9.63. Research and Development Cost Estimates for Sphere-Pac Fabrication

[NASAP Case 6.2.1, LMFBR U-Pu/U Spiked Recycle (Westinghouse Reference) Heterogeneous Core Design]

\begin{tabular}{|c|c|c|c|c|}
\hline & R\&D Categories & Current Status ${ }^{a}$ & $\begin{array}{l}\text { R\&D Cost Estimates } \\
\text { (Millions of } \\
1978 \$ \text { ) }\end{array}$ & $\begin{array}{l}\text { Years to } \\
\text { Complete }\end{array}$ \\
\hline 1.0 & Program management & Not applicable & 10 & 10 \\
\hline 2.0 & Design studies & $\mathrm{N}-$ cold engineering & 25 & 10 \\
\hline 3.0 & Receiving and storage & P - cold engineering & 4 & 5 \\
\hline 4.0 & Fuel production & $P$ - hot engineering & 25 & 6 \\
\hline 5.0 & Fuel rod fabrication & P - cold 1aboratory & 50 & 8 \\
\hline 6.0 & Fuel element assembly & $\mathrm{N}-$ cold engineering & 27 & 8 \\
\hline 7.0 & Scrap recovery & $\mathrm{N}$ - cold engineering & 3 & 5 \\
\hline 8.0 & Waste treatment & $b$ & $b$ & $b$ \\
\hline 9.0 & Plant control systems & $\mathrm{N}-\operatorname{cold}$ prototype & 5 & 8 \\
\hline 10.0 & Maintenance & N - cold prototype & 5 & 10 \\
\hline 11.0 & $\begin{array}{l}\text { Safeguards and account- } \\
\text { ability adaptation }{ }^{c}\end{array}$ & $\mathrm{P}-$ cold engineering & 6 & 6 \\
\hline & Subtotal & & 160 & \\
\hline \multicolumn{5}{|c|}{ Special Facilities } \\
\hline \multicolumn{2}{|c|}{ Hot tests } & & 10 & \\
\hline \multicolumn{2}{|c|}{ Cold prototype } & & 25 & \\
\hline & Total & & $195^{d}$ & \\
\hline & Range & & $185-235$ & \\
\hline $\begin{array}{l}\mathrm{N}= \\
\text { app1 } \\
\operatorname{mil1}\end{array}$ & $\begin{array}{l}a_{\text {Status stage with qualit }} \\
\text { eeded. } \\
b_{\text {To be supplied by others }} \\
c_{\text {Assumes basic technology }} \\
\text { cations testing, systems } \\
d_{\text {The estimate does not in }} \\
\text { on) or the capital costs }\end{array}$ & $\begin{array}{l}\text { tive modifiers; } \mathrm{C}=\mathrm{cor} \\
\text { as developed under oss } \\
\text { ntegration, and testing } \\
\text { lude costs for fuel qu } \\
\text { f a pilot plant estima }\end{array}$ & $\begin{array}{l}\text { Lete, } P=\text { in progre } \\
\text { stimate presented } \\
\text { ification tests }(a t \\
\text { d at } \$ 160 \text { million. }\end{array}$ & $\begin{array}{l}s, \text { and } \\
\text { for } \\
\text { ut } \$ 20\end{array}$ \\
\hline
\end{tabular}


LMFBR fuel elements is considerably different. These differences in design result in modifications to the details for accomplishing the various functional activities and modifications to the facility design details. In the subsequent paragraphs, each of the functional activities is discussed as it applies to this case.

A generic ge1-sphere-pac functional flow diagram is given in Fig. 3.1 of Sect. 3.1.1 of this report. The major functional areas apply to this case, and the two main functions unique to the gel-sphere-pac process are fuel production (2.0) and fuel rod fabrication (3.0). All the functional steps are briefly discussed here.

Receiving and Storage. This functional area is quite similar to the reference case. However, in addition to the spheres, the $\mathrm{UO}_{2}$ pellets from the adjacent radial blanket assembly plant must be received, inspected, and stored.

Fuel Production. The fuel production processes for the spheres are essentially the same as those described for the reference case including calcination, sintering, and inspection of the coarse and medium sizes, which contain plutonium. No processing is planned for the $\mathrm{UO}_{2}$ fines because they are to be sintered at the reprocessing conversion step. However, because the $\mathrm{UO}_{2}$ axial blanket pellets make up approximately $37 \%$ of the total heavy metal content in a core fuel assembly, the quantity of coarse and medium spheres processed is significantly less than in the reference case.

Fuel Rod Fabrication. While most of the fuel rod fabrication processes are similar to the reference case, additional steps are required to incorporate the axial blanket material. The lower axial blanket section is loaded into the fuel rod cladding before the cladding is introduced into the cell. After the $(\mathrm{U}, \mathrm{Pu})_{2}$ core region is loaded by the sphere-pac process into each rod and inspected for density the upper axial blanket section will be loaded by equipment similar to that used for inserting plenum hardware. The actual plenum hardware insertion and end cap welding operations are essentially the same as those described for the reference case.

Fuel Assembly Operations. The fuel assembly design for this LMFBR case 6.2.1 is identical to that for the pellet fabrication option. 
Following fuel rod inspection each rod will be remotely wrapped with a wire. This special wire wrap will space the fuel rods in the assembly. Groups of these rods are assembled onto $T$-bars of varying length. The T-bar strip layers are assembled and fastened to the lower end box of the fuel assembly. The duct tube is installed and the finished assembly is inspected.

Product Control Processes. These are the same as the reference case (see Sect. 4.1.2).

Scrap and Waste Processing and Disposal. The scrap handling processes are similar to the reference case (see Sect.4.1.2) with the added feature that all axial blanket pellets that are unloaded from an unsatisfactory rod are inspected, and acceptable pellets are recycled within the remotely operated part of the facilities to form upper axial blankets.

\subsubsection{Preliminary Cost Estimate for Construction and Operation of a Commercial-Scale Plant}

The cost components that were estimated include capital costs for the facility and equipment, fuel assembly hardware costs, material and supply costs, and operating costs.

Facility capital cost estimates were based on an analysis of the functional flow diagram for the process to indicate space requirements for each functional area and for each support area. Equipment requirements were identified, and costs associated with the equipment were estimated. Fuel assembly hardware requirements were based on the reference fuel assembly design parameters identified in Table 9.59. Estimates of the costs of the hardware items were obtained. Material and supply requirements were identified from the sphere-pac process description, and estimates of the costs of materials and supplies were obtained. Operating cost estimates included consideration of personnel, overhead, general and administrative expenses, and costs of utilities.

The facility was assumed to operate as a toll processing facility. That is, the operator fabricates customer-supplied fuel feed materials into finished fuel assemblies, and thus costs of plutonium and uranium 
were not included in the cost estimates. The hardware and material costs do include the costs associated with the production of the $\mathrm{UO}_{2}$ pellets for the axial blanket.

Unit costs for fabrication of fuel assemblies are determined by an economic analysis of the basic capital, hardware and material, and operating cost estimates. Basically, the economic analysis provides for the owner of the fuel fabrication facility to recover all capital, operating, and finance charges plus a return on investment, if appropriate, over the life of the plant.

In order to provide a range of prices (i.e., costs to a customer), economic analyses were based on government financing, financing appropriate for a conventional-risk (typical) industry, and financing appropriate for a high-risk industry. ${ }^{2}$ The estimated costs, costs derived from the economic analysis, and the unit costs based on the three different financing methods are summarized in Table 9.64. As may be observed from the table, the price for fabrication of ( $\mathrm{U}, \mathrm{Pu}) \mathrm{O}_{2}-\mathrm{UO}_{2}$ fuel is expected to be in the range from $\$ 370$ to $\$ 710 / \mathrm{kg}$ depending on the financing technique that is employed. The recommended cost for comparison with other fuel cycles and methods of fabrication is the typical industry cost of $\$ 570 / \mathrm{kg}$ of heavy metal. As with all the cost estimates in this report, the prices are based on the mass of all heavy metal in the finished assembly. For this case, this includes the uranium in the axial blankets. 
Table 9.64. Summary of Costs for Fabrication of Sphere-Pac PWR Fuel in a 2-t HM/d Facility [NASAP Case 6.2.1 LMFBR U-Pu/U Spiked Recycle (Westinghouse Reference) -

Heterogeneous Core Design]

\begin{tabular}{|c|c|c|c|c|c|c|c|c|c|}
\hline \multirow[b]{2}{*}{$\begin{array}{c}\text { Economic } \\
\text { Set } a\end{array}$} & \multicolumn{4}{|c|}{ Estimated Costs, $\$$ million } & \multicolumn{4}{|c|}{ Derived Costs, $\$$ million } & \multirow[b]{2}{*}{$\begin{array}{l}\text { Unit } \\
\text { Costb } \\
(\$ / \mathrm{kg})\end{array}$} \\
\hline & Facility & Equipment & $\begin{array}{l}\text { Annual } \\
\text { Hardware } \\
\text { P1us } \\
\text { Materials }\end{array}$ & $\begin{array}{c}\text { Annual } \\
\text { Operating }\end{array}$ & $\begin{array}{c}\text { Owner's } \\
\text { Cost } \\
\text { During } \\
\text { Construction }\end{array}$ & $\begin{array}{c}\text { Charge on } \\
\text { Direct Capital } \\
\text { During } \\
\text { Construction }\end{array}$ & $\begin{array}{c}\text { Annual } \\
\text { Equipment } \\
\text { Replacement } \\
\text { Cost }\end{array}$ & $\begin{array}{l}\text { Annual } \\
\text { Payment to } \\
\text { Decommissioning } \\
\text { Fund }\end{array}$ & \\
\hline A & 260 & 255 & 60 & 27 & 39 & 140 & 13 & 1.2 & 370 \\
\hline B & 260 & 255 & 60 & 28 & 41 & 200 & 13 & 1.3 & 570 \\
\hline c & 260 & 255 & 60 & 29 & 42 & 200 & 13 & 1.3 & 710 \\
\hline
\end{tabular}

$a_{\mathrm{A}}=$ Government financing; $\mathrm{B}=$ Typical industrial financing; $\mathrm{C}=$ High-risk industrial financing.

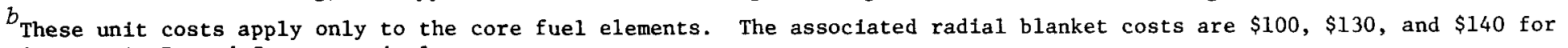
economic sets $A, B$, and $C$, respectively. 


\subsection{NASAP CASE 6.2.2, LMFBR U-Pu/U SPIKED RECYCLE (GENERAL ELECTRIC REFERENCE) HOMOGENEOUS CORE DESIGN}

\subsubsection{Fue1 Cycle Description}

This reactor-fuel cycle combination and mass flows are identical to that discussed in case 6.1 (Sect. 9.13) except that the core fuel assemblies are preirradiated before shipment. This reactor-fuel cycle combination is an LMFBR using recycled coprocessed $\mathrm{U}-\mathrm{Pu}$ mixed oxide in a homogeneous core and recycled uranium mixed with makeup depleted uranium in the axial and radial blanket assemblies. The core fuel is reprocessed separately from the blanket assemblies. All the coprocessed, recovered $\mathrm{U}-\mathrm{Pu}$ from the core is mixed with makeup uranium and some of the U-Pu recovered from blanket reprocessing is used for feed material to core fabrication. The excess coprocessed U-Pu from blanket reprocessing is sent to secure storage for later use in LWRs or LMFBRs. All other recovered uranium from blanket reprocessing is recycled to blanket fabrication after being mixed with makeup depleted uranium.

In this cycle analysis only fabrication of the core assemblies is considered. The products of the reprocessing plant are highly decontaminated and include the coarse and medium sizes of spherical particles with the appropriate uranium-to-plutonium ratio and the recycled $\mathrm{UO}_{2}$ fines. The assumption was that excess uranium from the reprocessing plant and/or makeup depleted uranium will be fabricated by the pellet process into radial blanket assemblies in an adjacent contact-operated and contactmaintained ( $\mathrm{CO} / \mathrm{CM}$ ) facility. Urania pellets from that adjacent facility will be used in the core fabrication facility for the axial blankets in the core assemblies.

The extended burnup of the recycle plutonium will cause this material to have significant radioactivity; consequently, a remotely operated and contact-maintained $(\mathrm{RO} / \mathrm{CM})$ facility is required for the core assemblies for this cycle. 


\subsubsection{Applicability to Current Fuel Element Design}

The core fuel element design chosen for this cycle is given in Table 9.65.

The key considerations for sphere-pac applicability are the cladding inside diameter measurements and the required fuel smear density. The cladding ID of $6760 \mu \mathrm{m}$ in the reference design is suitable for the spherepac process. Although the specified smear density of $90 \%$ of theoretical is above that currently achieved with experimental blended (three particle size) sphere-pac beds, we have assumed that the process is applicable through a slight lowering of this design requirement.

\subsubsection{Definition of Plant Production Requirements and Design Capacity}

For this LMFBR (U, Pu)O $\mathrm{O}_{2}-\mathrm{UO}_{2}$ fuel cycle, the plant design assumptions are listed below. The heavy metal through-put for this plant and all cases involving axial blanket fuel is based on the total heavy metal in the finished fuel assembly, in both core and axial blanket heavy metal.

1. The fuel design is the General Electric Company Advanced Reactor Systems Department homogeneous reactor reference fuel design.

2. The plant production capacity is $480 \mathrm{t} \mathrm{HM} /$ year with the capability for simultaneous production of three enrichments.

3. The plant factor is 240 effective full-production days per year.

4. Plant design capacity:

Overa11

Each line of three
$730 \mathrm{t} \mathrm{HM} /$ year

about 5 fuel assemblies/d

$243 \mathrm{t} \mathrm{HM} /$ year

$0.67 \mathrm{t} \mathrm{HM} / \mathrm{d}$

1080 fuel rods/d

4. 0 fuel assemblies/d

5. Process design capacities are based on the line design capacities and the scrap and sample losses defined in Sect. 9.15.4.

6. The facilities are designed to discharge no 1iquid waste other than treated sanitary sewage. 
Table 9.65. Summary of General Electric Reference LMFBR Fuel Assembly Parameters

(NASAP Case 6.2.2, LMFBR U-Pu/U Spiked Recycle)

\section{Reactor Characteristics}

Reactor power

Fuel assemblies

Inner blanket assemblies

Radial blanket assemblies

Control assemblies

Removable shield assemblies

Fissile enrichment, \%

\section{Component Characteristics}

Fuel cladding

End plugs

Top

Bottom

Reflector rods

Plenum springs

Spacers

Wire wrap

Attachment rails

Locking pins

Shield and inlet assemblies

Duct and upper handling socket

Fuel Rod Characteristics

Fuel cladding outside diameter Fuel cladding inside diameter

Fuel rod length

Plenum length

Upper

Lower

Core fuel height

Axial blanket height

Upper

Lower

Pellet density

Fuel smear density

Pellet diameter

Pellet length

Wire wrap diameter

Bonding

\section{Fue1 Assemb1y Characteristics}

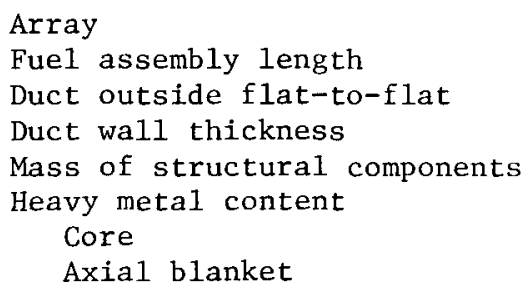

1000 MWe (net)

252 (150 zone 1; 102 zone 2)

Not applicable

198

19

240

Zone $1-10.24$, zone $2,-14.36$

\begin{tabular}{|c|c|c|c|}
\hline Material & & $\begin{array}{c}\text { Number per } \\
\text { Fuel Assemb1y }\end{array}$ & $\begin{array}{l}\text { Mass (kg) per } \\
\text { Fuel Assembly }\end{array}$ \\
\hline Improved 316 & SS & 271 & \\
\hline Improved 316 & SS & 271 & \\
\hline Improved 316 & SS & 271 & \\
\hline $316 \mathrm{SS}$ & & 271 & \\
\hline Improved 316 & SS & 1 & \\
\hline Improved 316 & SS & 1 & \\
\hline
\end{tabular}

Number per Mass ( $\mathrm{kg}$ ) per

271

271

$$
\begin{aligned}
& 7.37 \mathrm{~mm}(0.290 \mathrm{in.}) \\
& 6.76 \mathrm{~mm}(0.266 \mathrm{in.}) \\
& 2.85 \mathrm{~m}(112 \mathrm{in.}) \\
& 914.4 \mathrm{~mm}(36.0 \mathrm{in.}) \\
& \text { Not applicable } \\
& 1219 \mathrm{~mm}(48.0 \mathrm{in.}) \\
& 356 \mathrm{~mm}(14.0 \mathrm{in.}) \\
& 356 \mathrm{~mm}(14.0 \mathrm{in.}) \\
& 90 \% \mathrm{T.D} . \\
& 6.62 \mathrm{~mm}(0.2605 \mathrm{in.}) \\
& 1.44 \mathrm{~mm}(0.0567 \mathrm{in.}) \\
& \mathrm{He}
\end{aligned}
$$

\section{Hexagona1}

$154.5 \mathrm{~mm}$ (6.083 in.)

$3.18 \mathrm{~mm}$ (0.125 in.)

$103.74 \mathrm{~kg}$

$63.48 \mathrm{~kg}$ 
7. All process buildings and critical auxiliary support are designed and constructed in accordance with current United States Nuclear Regulatory Commission licensing requirements. Shielding is provided to limit dose rates to operating and maintenance personnel to $0.25 \mathrm{millirem} / \mathrm{h}$.

In addition, we assumed that production from each fuel rod line is campaigned to provide a full reload segment for a single 1000-MWe LMFBR. Thus, the total heavy metal output for a given campaign is $21.1 \mathrm{t}$, and each campaign requires 31.6 effective ful1-production days ( 48 calendar days). The total facility, with an adjacent radial blanket assembly plant, can support approximately 28 such reactors.

9.15.4 Estimates of Surge Storage Requirements, Scrap Production Rates, and Processing Rates for Functional Steps

Given the plant design assumptions defined in Sect.9.15.3, further commercial plant characteristics were derived.

To achieve the annual production rates, an analysis of the plant surge storage requirements and normal inventory was made, and the results of this analysis are given in Table 9.66.

Based on current technology and assuming reasonable extrapolations for commercial-scale developments, a preliminary estimate was made of the daily mass flows of heavy metal through the fabrication plant and the average production rate of heavy metal scrap materials from the various functional activities. These are presented in Table 9.67.

Given the above information, a preliminary evaluation of the processing rate for each functional step within the main fuel fabrication processes was made. The results of this analysis are summarized in Table 9.68.

\subsubsection{Analysis of Functional Technology Status, Research and Development Requirements, Cost, and Schedule}

The technology status of this system is quite similar to that of the reference case discussed in Sect. 8. The current status and research and development needs are summarized in Table 9.69. The primary difference 
Table 9.66. Sphere-Pac Fabrication Plant Surge Storage Requirements and Normal Inventory [NASAP Case 6.2.2, LMFBR U-Pu/U Spiked Recycle (GE Reference) Homogeneous Core Design]

\begin{tabular}{|c|c|c|c|c|c|c|}
\hline \multirow{2}{*}{ Process step } & \multirow{2}{*}{ Material } & \multicolumn{2}{|c|}{$\begin{array}{c}\text { Storage } \\
\text { Interval, } \mathrm{d}\end{array}$} & \multicolumn{3}{|c|}{ Norma1 Inventory, $\mathrm{kg} \mathrm{HM}$} \\
\hline & & Norma 1 & Maximum & $(\mathrm{Pu}, \mathrm{U}) \mathrm{O}_{2}$ & $\mathrm{UO}_{2}$ Fines & $\mathrm{UO}_{2}$ Pellets \\
\hline Feed storage & $\begin{array}{l}\text { Dried spheres } \\
\text { Sintered spheres } \\
\text { Sintered pellets }\end{array}$ & $\begin{array}{l}30 \\
30 \\
30\end{array}$ & $\begin{array}{l}60 \\
60 \\
60\end{array}$ & 31,000 & 8,200 & 10,400 \\
\hline Interim storage & $\begin{array}{l}\text { Dried spheres } \\
\text { Sintered spheres } \\
\text { Sintered pellets }\end{array}$ & $\begin{array}{l}1 \\
1 \\
1\end{array}$ & $\begin{array}{l}2 \\
2 \\
2\end{array}$ & 1,030 & 270 & 350 \\
\hline Furnace & $\begin{array}{l}\text { Dried to sintered } \\
\text { spheres }\end{array}$ & 1.2 & 2.4 & 1,240 & & \\
\hline Post furnace & Sintered spheres & 0.5 & 1 & 515 & & \\
\hline Interim storage & Sintered spheres & 0.36 & 0.72 & 370 & & \\
\hline Main storage & $\begin{array}{l}\text { Sintered spheres } \\
\text { Sintered spheres } \\
\text { Sintered pellets }\end{array}$ & $\begin{array}{l}1.2 \\
1.5 \\
1.5\end{array}$ & $\begin{array}{l}2.4 \\
2.9 \\
2.9\end{array}$ & 1,300 & 410 & 590 \\
\hline $\begin{array}{l}\text { Loading, inspection, } \\
\text { welding }\end{array}$ & $\begin{array}{l}\text { Sintered spheres } \\
\text { and pellets }\end{array}$ & 0.12 & 0.24 & 130 & 35 & 50 \\
\hline $\begin{array}{l}\text { Loaded, not inspected } \\
\text { rods }\end{array}$ & $\begin{array}{l}\text { Sintered spheres } \\
\text { in rods }\end{array}$ & 5 & 5 & 5,100 & 1,290 & 3,940 \\
\hline Rework and scrap & $\begin{array}{l}\text { Sintered spheres } \\
\text { and pellets }\end{array}$ & 2 & 5 & 250 & 45 & 100 \\
\hline Completed fuel rods & $\begin{array}{l}\text { Sintered spheres } \\
\text { and pellets } \\
\text { in rods }\end{array}$ & 5 & 5 & 4,990 & 1,250 & 3,820 \\
\hline Assemb1y & $\begin{array}{l}\text { Rods in completed } \\
\text { assemblies }\end{array}$ & 15 & 30 & 15,000 & 3,740 & 11,400 \\
\hline
\end{tabular}


Table 9.67. Heavy Metal Mass Flows and Average Scrap Production for a Sphere-Pac Fuel Fabrication P1ant [NASAP Case 6.2 .2 , LMFBR U - Pu/U Spiked Recycle (GE Reference) Homogeneous Core Design]

\begin{tabular}{|c|c|c|c|c|c|c|c|c|c|}
\hline \multirow{3}{*}{ Processing step } & \multicolumn{9}{|c|}{ Mass Flow, $\mathrm{kg} \mathrm{HM} / \mathrm{d}$} \\
\hline & \multicolumn{3}{|c|}{ Daily Throughput } & \multicolumn{3}{|c|}{ Clean $\operatorname{scrap}^{b}$} & \multicolumn{3}{|c|}{ Reject Scrap ${ }^{\circ}$} \\
\hline & $(\mathrm{Pu}, \mathrm{U}) \mathrm{O}_{2}{ }^{a}$ & $\begin{array}{l}\mathrm{UO}_{2} \\
\text { Fines }\end{array}$ & $\begin{array}{l}\text { Axial Blanket } \\
\mathrm{UO}_{2} \text { Pellets }\end{array}$ & $(\mathrm{Pu}, \mathrm{U}) \mathrm{O}_{2}{ }^{\mathrm{a}}$ & $\begin{array}{c}\mathrm{UO}_{2} \\
\mathrm{~F}_{2} \text { nes }\end{array}$ & $\begin{array}{c}\text { Axıal Blanket } \\
\mathrm{UO}_{2} \text { Pellets }\end{array}$ & $(\mathrm{Pu}, \mathrm{U}) \mathrm{O}_{2}$ & $\begin{array}{l}\mathrm{UO}_{2} \\
\text { Fines }\end{array}$ & $\begin{array}{c}\text { Axial Blanket } \\
\mathrm{UO}_{2} \text { Pellets }\end{array}$ \\
\hline Recelving and storage & 1031.2 & $271.6^{d}$ & 762.2 & & & & & & \\
\hline Sampling and batch loading & 1030.2 & & & & & & 1.0 & & \\
\hline Weighing and sampling & & 271.3 & $761.5^{e}$ & & & & & 0.2 & 0.8 \\
\hline Calcining and sintering & 1029.7 & & & & & & 0.5 & & \\
\hline Sphere upgrading & $1087.6^{f}$ & & & & & & 30.9 & & \\
\hline Sphere sampling & 1085.4 & & & & & & 2.2 & & \\
\hline Interim storage & 1085.4 & 271.3 & 415.1 & & & & & & \\
\hline Fuel rod loading & 1085.4 & 271.3 & 415.1 & & & & & & \\
\hline Fuel rod scanning & 1031.1 & 257.8 & $788.7^{9}$ & 52.1 & 13.0 & 19.9 & 2.2 & 0.5 & 0.8 \\
\hline Top component insertion & 1028.9 & 257.2 & 787.0 & 2.1 & 0.5 & 1.6 & 0.2 & 01 & 0.2 \\
\hline Rod welding and $x$ ray & 1028.9 & 257.2 & 787.0 & $h$ & $h$ & $h$ & $h$ & $h$ & $n$ \\
\hline Leak detection & 1028.9 & 257.2 & 787.0 & $h$ & $h$ & $h$ & $\hbar$ & $h$ & $n$ \\
\hline Rod assay & 1008.3 & 252.1 & 771.2 & 19.5 & 4.9 & 15.0 & 1.0 & 0.3 & 0.8 \\
\hline Final rod inspection & 997.8 & 249.4 & 763.2 & 101 & 2.5 & 7.7 & 0.4 & 0.1 & 0.3 \\
\hline Assemb1y inspection & 992.6 & 248.2 & 759.2 & 5.0 & 1.2 & 3.8 & 0.2 & $\underline{0.05}$ & $\underline{0.2}$ \\
\hline Total & & 2000 & & 88.8 & 22.1 & 48.0 & 38.6 & 1.3 & 3.1 \\
\hline
\end{tabular}

$a_{10.24}$ and $14.36 \%$ average fissile plutonium content in zones $I$ and 2 , respectively.

$b$ Internally recycled.

collected, assayed, and externally recycled to reprocessing plant.

$d_{\text {Includes } 22.1 \mathrm{~kg} \text { of recycled clean scrap. }}$

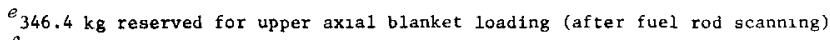

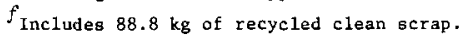

${ }^{9}$ Includes $48.0 \mathrm{~kg}$ of recycled clean scrap and $346.4 \mathrm{~kg}$ of fresh materlal.

$h_{\text {Rework }}$ in these steps is only of weld and does not affect scrap. 
Table 9.68. Equ1pment Requirements for Functional Areas [NASAP Case 6.2.2 LMFBR U-Pu/U Spiked Recycle (GE Reference) Homogeneous Core Design]

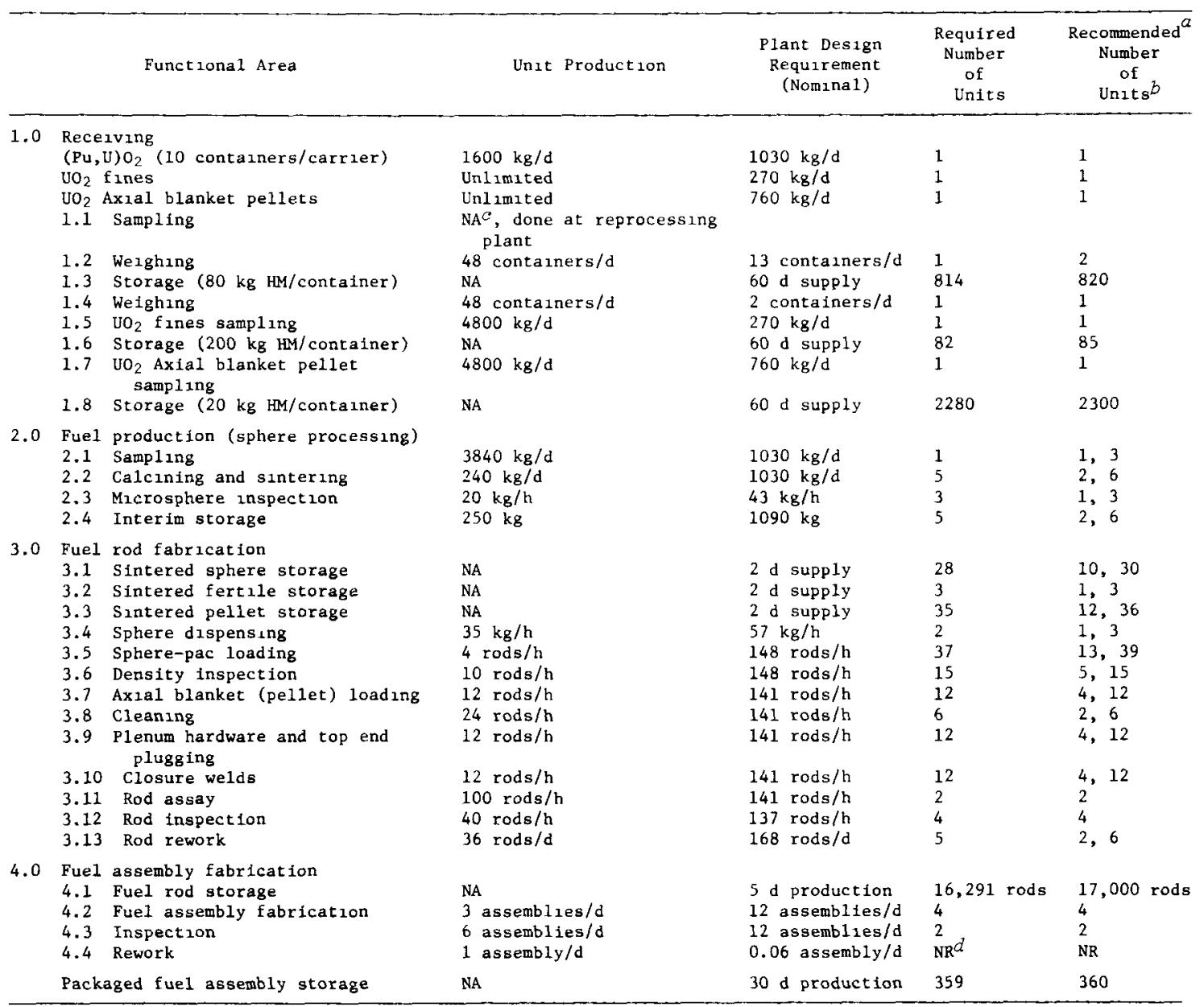

a Recommended units include consideration of spare capacity for operational reliability.

$b$ Number of units is for the facility if a single number; otherwise, units per 1ine, total units in factlity.

NA: not applicable.

$d_{\mathrm{NR}}$ : not required. Use assembly equipment as ava1lable. 
Table 9.69. Research and Development Cost Estimates for Sphere-Pac Fabrication [NASAP Case 6.2.2, LMFBR U-Pu/U Spiked Recycle (GE Reference) Homogeneous Core Design]

\begin{tabular}{|c|c|c|c|c|}
\hline & $R \& D$ Categories & Current Status ${ }^{a}$ & $\begin{array}{c}\text { R\&D Cost Estimates } \\
\text { (Millions of } \\
1978 \text { \$) }\end{array}$ & $\begin{array}{l}\text { Years to } \\
\text { Complete }\end{array}$ \\
\hline 1.0 & Program management & Not applicable & 10 & 10 \\
\hline 2.0 & Design studies & $\mathrm{N}-$ cold engineering & 25 & 10 \\
\hline 3.0 & Receiving and storage & $P-$ cold engineering & 4 & 5 \\
\hline 4.0 & Fuel production & $P$ - hot engineering & 25 & 6 \\
\hline 5.0 & Fuel rod fabrication & $P-$ cold engineering & 50 & 8 \\
\hline 6.0 & Fuel element assembly & $\mathrm{N}-$ cold engineering & 27 & 8 \\
\hline 7.0 & Scrap recovery & $\mathrm{N}$ - cold engineering & 3 & 5 \\
\hline 8.0 & Waste treatment & $b$ & $b$ & $b$ \\
\hline 9.0 & Plant control systems & $N-$ cold prototype & 5 & 8 \\
\hline 10.0 & Maintenance & $\mathrm{N}$ - cold prototype & 5 & 10 \\
\hline 11.0 & $\begin{array}{l}\text { Safeguards and account- } \\
\text { ability adaptation }{ }^{c}\end{array}$ & $P$ - cold engineering & 6 & 6 \\
\hline & Subtotal & & 160 & \\
\hline \multicolumn{5}{|c|}{ Special Facilities } \\
\hline \multicolumn{3}{|c|}{ Hot tests } & 10 & \\
\hline \multicolumn{3}{|c|}{ Cold prototype } & 25 & \\
\hline & Total & & $195^{d}$ & \\
\hline & Range & & $185-235$ & \\
\hline
\end{tabular}

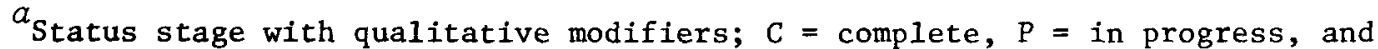
$\mathrm{N}=$ needed.

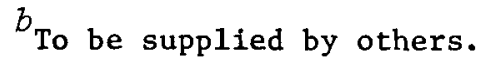

${ }^{C}$ Assumes basic technology as developed under oSS estimate presented is for applications testing, systems integration, and testing.

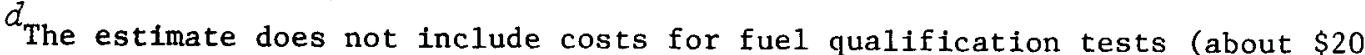
million) or the capital costs of a pilot plant estimated at $\$ 160$ million. 
between this $\mathrm{U}-\mathrm{Pu}$ fuel and the reference $\mathrm{U}-\mathrm{Pu}$ fuel is the much higher concentration of plutonium. Development is under way in the United States on sphere forming, calcination, and sintering of ( $\mathrm{U}, \mathrm{Pu})_{2}$ with $\mathrm{Pu} / \mathrm{U}$ ratios adequate for both the reference case and the fast reactor fuels.

While the functional fabrication processes are the same as those given for the reference gel-sphere-pac fabrication case, the design of the LMFBR fuel elements is considerably different. These differences in design result in modifications to the details for accomplishing the various functional activities and modifications to the facility design details. In the subsequent paragraphs, each of the functional activities is discussed as it applies to this case.

A generic gel-sphere-pac functional flow diagram is given in Fig. 3.1 of Sect. 3.1.1 of this report. The major functional areas apply to this case, and the two main functions unique to the gel-sphere-pac process are fuel production (2.0) and fuel rod fabrication (3.0). All the functional steps are briefly discussed here.

Receiving and Storage. This functional area is quite similar to the reference case. However, in addition to the spheres, the $\mathrm{UO}_{2}$ pellets from the adjacent radial blanket assembly plant must be received, inspected, and stored.

Fuel Production. The fuel production processes for the spheres are essentially the same as those described for the reference case including calcination, sintering, and inspection of the coarse and medium sizes, which contain plutonium. No processing is planned for the $\mathrm{UO}_{2}$ fines because they are to be sintered at the reprocessing conversion step. However, because the $\mathrm{UO}_{2}$ axial blanket pellets make up approximately $38 \%$ of the total heavy metal content in a core fuel assembly, the quantity of coarse and medium spheres processed is significantly less than in the reference case.

Fuel Rod Fabrication. While most of the fuel rod fabrication processes are similar to the reference case, additional steps are required to incorporate the axial blanket material. The lower axial blanket section is loaded into the fuel rod cladding before the cladding is introduced into the cell. After the $(\mathrm{U}, \mathrm{Pu})_{2}$ core region is loaded by the sphere-pac process into each rod and inspected for density the upper axial blanket 
section will be loaded by equipment similar to that used for inserting plenum hardware. The actual plenum hardware insertion and end cap welding operations are essentially the same as those described for the reference case.

Fuel Assembly Operations. The fuel assembly design for this LMFBR case 6.2.2 is identical to that for the pellet fabrication option. Following fuel rod inspection each rod will be remotely wrapped with a wire. This special wire wrap will space the fuel rods in the assembly. Groups of these rods are assembled onto T-bars of varying length. The T-bar strip layers are assembled and fastened to the lower end box of the fuel assembly. The duct tube is installed and the finished assembly is inspected.

Product Control Processes. These are the same as the reference case (see Sect. 4.1.2).

Scrap and Waste Processing and Disposal. The scrap handling processes are similar to the reference case (see Sect. 4.1.2) with the added feature that all axial blanket pellets that are unloaded from an unsatisfactory rod are inspected, and acceptable pellets are recycled within the remotely operated part of the facilities to form upper axial blankets.

\subsubsection{Preliminary Cost Estimate for Construction and Operation of a Commercia1-Scale Plant}

The cost components that were estimated include capital costs for the facility and equipment, fuel assembly hardware costs, material and supply costs, and operating costs.

Facility capital cost estimates were based on an analysis of the functional flow diagram for the process to indicate space requirements for each functional area and for each support area. Equipment requirements were identified, and costs associated with the equipment were estimated. Fuel assembly hardware requirements were based on the reference fuel assembly design parameters identified in Table 9.65. Estimates of the costs of the hardware items were obtained. Material and supply requirements were identified from the sphere-pac process description, and 
estimates of the costs of materials and supplies were obtained. Operating cost estimates included consideration of personne1, overhead, general and administrative expenses, and costs of utilities.

The facility was assumed to operate as a toll processing facility. That is, the operator fabricates customer-supplied fuel feed materials into finished fuel assemblies, and thus costs of plutonium and uranium were not included in the cost estimates. The hardware and material costs do include the costs associated with the production of the $\mathrm{UO}_{2}$ pellets for the axial blanket.

Unit costs for fabrication of fuel assemblies are determined by an economic analysis of the basic capital, hardware and material, and operating cost estimates. Basically, the economic analysis provides for the owner of the fuel fabrication facility to recover all capital, operating, and finance charges plus a return on investment, if appropriate, over the life of the plant.

In order to provide a range of prices (i.e., costs to a customer), economic analyses were based on government financing, financing appropriate for a conventional-risk (typical) industry, and financing appropriate for a high-risk industry. 2 The estimated costs, costs derived from the economic analysis, and the unit costs based on the three different financing methods are summarized in Table 9.70. As may be observed from the table, the price for fabrication of $(\mathrm{U}, \mathrm{Pu})_{2}-\mathrm{UO}_{2}$ fuel is expected to be in the range from $\$ 380$ to $\$ 730 / \mathrm{kg}$ depending on the financing technique that is employed. The recommended cost for comparison with other fuel cycles and methods of fabrication is the typical industry cost of $\$ 580 / \mathrm{kg}$ of heavy metal. As with all the cost estimates in this report, the prices are based on the mass of all heavy metal in the finished assembly. For this case, this includes the uranium in the axial blankets. 
Table 9.70. Summary of Costs for Fabrication of Sphere-Pac PWR Fuel in a 2-t HM/d Facility [NASAP Case 6.2.2, LMFBR U-Pu/U Spiked Recycle (GE Reference) Homogeneous Core Design]

\begin{tabular}{|c|c|c|c|c|c|c|c|c|c|}
\hline \multirow[b]{2}{*}{$\begin{array}{c}\text { Economic } \\
\text { Set }^{a}\end{array}$} & \multicolumn{4}{|c|}{ Estimated Costs, \$ million } & \multicolumn{4}{|c|}{ Derived Costs, $\$$ million } & \multirow[b]{2}{*}{$\begin{array}{c}\text { Unit } \\
\text { Cost } \\
(\$ / \mathrm{kg})\end{array}$} \\
\hline & Facility & Equipment & $\begin{array}{c}\text { Annual } \\
\text { Hardware } \\
\text { Plus } \\
\text { Materials }\end{array}$ & $\begin{array}{c}\text { Annual } \\
\text { Operating }\end{array}$ & $\begin{array}{l}\text { Owner's } \\
\text { Cost } \\
\text { During } \\
\text { Construction }\end{array}$ & $\begin{array}{c}\text { Charge on } \\
\text { Direct Capital } \\
\text { During } \\
\text { Construction }\end{array}$ & $\begin{array}{l}\text { Annual } \\
\text { Equipment } \\
\text { Replacement } \\
\text { Cost }\end{array}$ & $\begin{array}{c}\text { Annual } \\
\text { Payment to } \\
\text { Decommissioning } \\
\text { Fund }\end{array}$ & \\
\hline A & 260 & 255 & 66 & 27 & 39 & 140 & 13 & 1.2 & 380 \\
\hline B & 260 & 255 & 66 & 28 & 41 & 200 & 13 & 1.3 & 580 \\
\hline $\mathrm{C}$ & 260 & 255 & 66 & 29 & 42 & 200 & 13 & 1.3 & 730 \\
\hline
\end{tabular}

$a_{\mathrm{A}}=$ Government financing; $\mathrm{B}=$ Typical industrial financing; $\mathrm{C}=$ High-risk industrial financing. 
9.16 NASAP CASE 6.3.1, LMFBR U-Pu/Th SPIKED RECYCLE, WESTINGHOUSE TRANSMUTER; HETEROGENEOUS CORE DESIGN

\subsubsection{Fue1 Cycle Description}

This reactor-fuel cycle combination is an LMFBR using $16 \%$ fissile $\mathrm{U}-\mathrm{Pu}$ core and an axial blanket of depleted uranium. In addition this reactor has internal and radial blanket assemblies of thorium oxide. Core fuel assemblies are preirradiated for spiking before shipment. Core and axial blanket assemblies are coprocessed, and the recovered $\mathrm{U}-\mathrm{Pu}$ is mixed with makeup $\mathrm{U}-\mathrm{Pu}$ as feed to core fabrication. Excess depleted uranium from core reprocessing is used as diluent to the ${ }^{233_{U}} \mathrm{U}$ recovered from the internal and radial blanket reprocessing and as feed to axial blanket fabrication. Makeup depleted uranium is required to complete axial blanket feed material requirements. The denatured (in process) $233_{\mathrm{U}}$ is stored in an interim storage facility. New thorium is used for internal and radial blanket fabrication.

In this cycle analysis only fabrication of the core assemblies is considered. The products of the reprocessing plant are highly decontaminated and include the coarse and medium sizes of spherical particles with the appropriate uranium-plutonium ratio and the recycled $\mathrm{UO}_{2}$ fines. Spiking is provided after fabrication by irradiation. We have assumed that excess uranium from the reprocessing plant and/or makeup depleted uranium will be processed in an adjacent contact-operated and contactmaintained $(\mathrm{CO} / \mathrm{CM})$ facility. In the same facility the $\mathrm{ThO}_{2}$ radial blanket assemblies are fabricated by the pellet process. Urania pellets from the special pellet processing line in the adjacent facility will be used in the core fabrication facility for the axial blankets in the core assemblies.

The extended burnup of the recycle plutonium will cause this material to have significant radioactivity; consequently, a remotely operated and contact-maintained ( $\mathrm{RO} / \mathrm{CM}$ ) facility is required for the core assemblies for this cycle. 


\subsubsection{Applicability to Current Fuel Element Design}

The core fuel element design chosen for this cycle is given in Table 9.71. These core elements are identical with those defined for Case 6.2.1, Sect. 9.14.

The key considerations for sphere-pac applicability are the cladding inside diameter measurements and the required fuel smear density. The cladding ID of $7210 \mu \mathrm{m}$ in the reference design is suitable for the spherepac process. Although the specified smear density of $91 \%$ of theoretical is above that currently achieved with experimental blended (three particle size) sphere-pac beds, we have assumed that the process is applicable through a slight lowering of this design requirement.

\subsubsection{Definition of Plant Production Requirements and Design Capacity}

For this LMFBR (U, Pu) $\mathrm{O}_{2}-\mathrm{UO}_{2}$ fuel cycle, the plant design assumptions are listed below. The heavy metal through-put for this plant and all cases involving axial blanket fuel is based on the total heavy metal in the finished fuel assembly, in both core and axial blanket.

1. The fuel design is the Westinghouse Electric Corporation Advanced Reactors Division heterogeneous core reactor reference large rod fuel design.

2. The plant production capacity is $480 \mathrm{t} \mathrm{HM} /$ year with the capability for simultaneous production of three enrichments.

3. The plant factor is 240 effective full-production days per year.

4. Plant design capacity:

Overall

Each line of three
$730 \mathrm{t} \mathrm{HM} /$ year

about 11 fuel assemblies/d

$243 \mathrm{t} \mathrm{HM} /$ year

$0.67 \mathrm{t} \mathrm{HM} / \mathrm{d}$

961 fuel rods/d

3.5 fuel assemblies/d

5. Process design capacities are based on the line design capacities and the scrap and sample losses defined in Sect.9.16.4. 
Table 9.71. Summary of Westinghouse Large Pin Transmuter LMFBR Fuel Assembly Parameters

(NASAP Case 6.3.1, LMFBR U-Pu/Th Spiked Recycle, Heterogeneous Core Design)

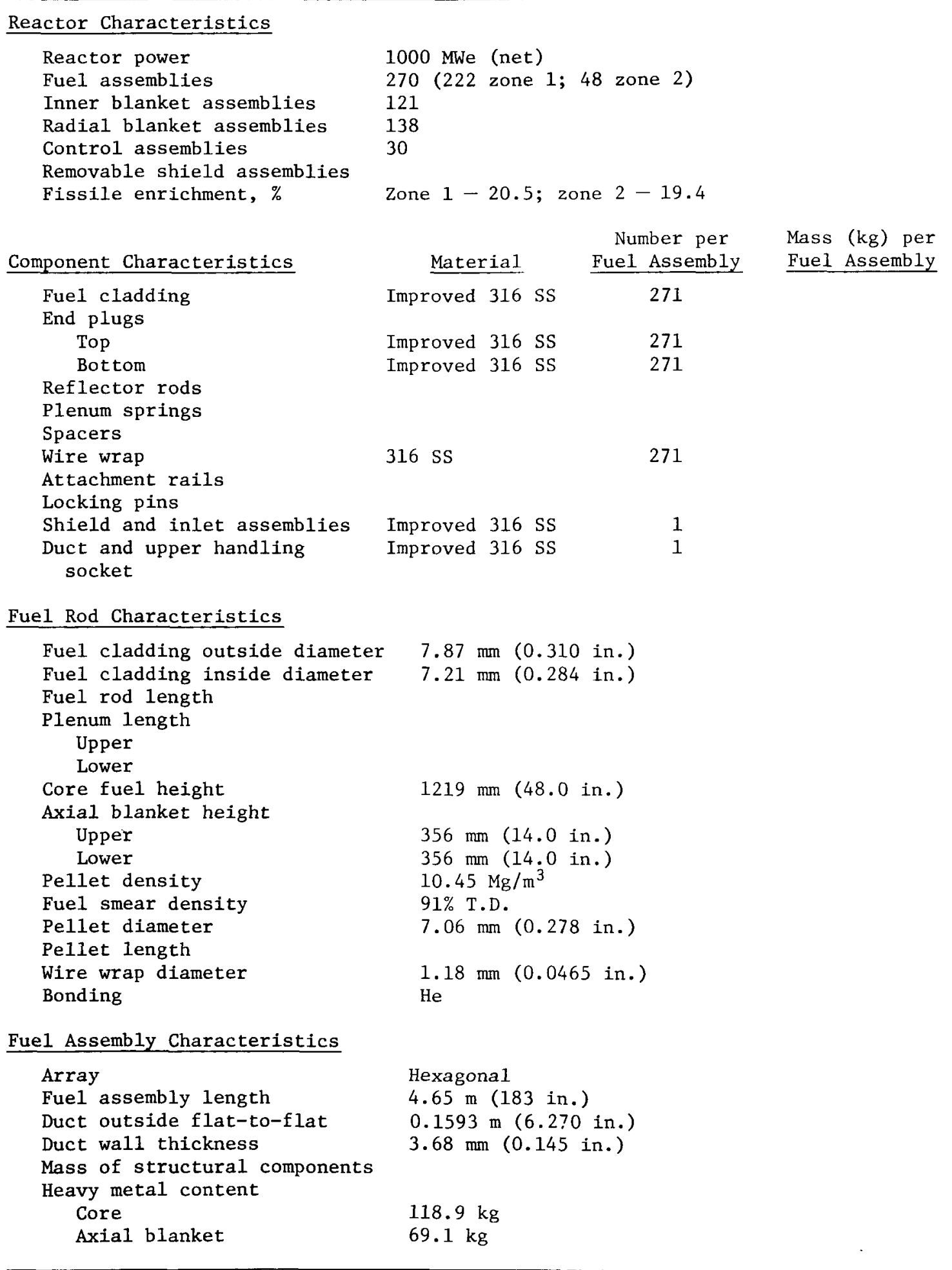


6. The facilities are designed to discharge no liquid waste other than treated sanitary sewage.

7. All process buildings and critical auxiliary support are designed and constructed in accordance with current United States Nuclear Regulatory Commission licensing requirements. Shielding is provided to limit dose rates to operating and maintenance personnel to $0.25 \mathrm{millirem} / \mathrm{h}$.

In addition, we assumed that production from each fuel rod line is campaigned to provide a full reload segment for a single 1000-MWe LMFBR. Thus, the total heavy metal output for a given campaign is $17 \mathrm{t}$, and each campaign requires 25.4 effective full-production days ( 39 calendar days). The total facility, with an adjacent radial blanket assembly plant, can support approximately 28 such reactors.

\subsubsection{Estimates of Surge Storage Requirements, Scrap Production Rates, and Processing Rates for Functional Steps}

Given the plant design assumptions defined in Sect.9.16.3, further commercial plant characteristics were derived.

To achieve the annual production rates, an analysis of the plant surge storage requirements and normal inventory was made, and the results of this analysis are given in Table 9.72.

Based on current technology and assuming reasonable extrapolations for commercial-scale developments, preliminary estimates were made of the daily mass flows of heavy metal through the fabrication plant and the average production rate of heavy metal scrap materials from the various functional activities. These are presented in Table 9.73.

Given the above information, a preliminary evaluation of the processing rate for each functional step within the main fuel fabrication processes was made. The results of this analysis are summarized in Table 9.74 .

\subsubsection{Analysis of Functional Technology Status, Research and Development Requirements, Cost, and Schedule}

The technology status of this system is quite similar to that of the reference case discussed in Sect. 8. The current status and research and 
Table 9.72. Sphere-Pac Fabrication Plant Surge Storage Requirements and Norma1 Inventory (NASAP Case 6.3.1, LMFBR U-Pu/Th Spiked Recycle, Westinghouse Transmuter Heterogeneous Core Design)

\begin{tabular}{|c|c|c|c|c|c|c|}
\hline \multirow{2}{*}{ Process step } & \multirow{2}{*}{ Material } & \multicolumn{2}{|c|}{$\begin{array}{c}\text { Storage } \\
\text { Interval, d }\end{array}$} & \multicolumn{3}{|c|}{ Normal Inventory, $\mathrm{kg} \mathrm{HM}$} \\
\hline & & Norma1 & Maximum & $(\mathrm{Pu}, \mathrm{U}) \mathrm{O}_{2}$ & $\mathrm{UO}_{2}$ Fines & $\mathrm{UO}_{2}$ Pellets \\
\hline Feed storage & $\begin{array}{l}\text { Dried spheres } \\
\text { Sintered spheres } \\
\text { Sintered pellets }\end{array}$ & $\begin{array}{l}30 \\
30 \\
30\end{array}$ & $\begin{array}{l}60 \\
60 \\
60\end{array}$ & 32,000 & 8,300 & 10,100 \\
\hline Interim storage & $\begin{array}{l}\text { Dried spheres } \\
\text { Sintered spheres } \\
\text { Sintered pellets }\end{array}$ & $\begin{array}{l}1 \\
1 \\
1\end{array}$ & $\begin{array}{l}2 \\
2 \\
2\end{array}$ & 1,100 & 280 & 340 \\
\hline Furnace & $\begin{array}{l}\text { Dried to sintered } \\
\text { spheres }\end{array}$ & 1.2 & 2.4 & 1,260 & & \\
\hline Post furnace & Sintered spheres & 0.5 & 1 & 1,530 & & \\
\hline Interim storage & Sintered spheres & 0.36 & 0.72 & 380 & & \\
\hline Main storage & $\begin{array}{l}\text { Sintered spheres } \\
\text { Sintered spheres } \\
\text { Sintered pellets }\end{array}$ & $\begin{array}{l}1.2 \\
1.5 \\
1.5\end{array}$ & $\begin{array}{l}2.4 \\
2.9 \\
2.9\end{array}$ & 1,300 & 410 & 570 \\
\hline $\begin{array}{l}\text { Loading, inspection, } \\
\text { welding }\end{array}$ & $\begin{array}{l}\text { Sintered spheres } \\
\text { and pellets }\end{array}$ & 0.12 & 0.24 & 130 & 35 & 45 \\
\hline $\begin{array}{l}\text { Loaded, not inspected } \\
\text { rods }\end{array}$ & $\begin{array}{l}\text { Sintered spheres } \\
\text { in rods }\end{array}$ & 5 & 5 & 5,200 & 1,310 & 3,810 \\
\hline Rework and scrap & $\begin{array}{l}\text { Sintered spheres } \\
\text { and pellets }\end{array}$ & 2 & 5 & 260 & 50 & 100 \\
\hline Completed fuel rods & $\begin{array}{l}\text { Sintered spheres } \\
\text { and pellets } \\
\text { in rods }\end{array}$ & 5 & 5 & 5,100 & 1,270 & 3,690 \\
\hline Assembly & $\begin{array}{l}\text { Rods in completed } \\
\text { assemblies }\end{array}$ & 15 & 30 & 15,000 & 3,810 & 11,100 \\
\hline
\end{tabular}




\begin{tabular}{|c|c|c|c|c|c|c|c|c|c|c|}
\hline \multirow{3}{*}{ Processing Step } & \multicolumn{10}{|c|}{ Mass Flow, $\mathrm{kg} \mathrm{HM} / \mathrm{d}$} \\
\hline & \multicolumn{3}{|c|}{ Da11y Throughput } & \multicolumn{3}{|c|}{ Clean Scrap $b$} & \multicolumn{4}{|c|}{ Reject Scrap ${ }^{C}$} \\
\hline & $(\mathrm{Pu}, \mathrm{U}) \mathrm{O}_{2}{ }^{a}$ & $\begin{array}{l}\mathrm{NO}_{2} \\
\text { Fines }\end{array}$ & $\begin{array}{l}\text { Axlal Blanket } \\
\mathrm{UO}_{2} \text { Pellets }\end{array}$ & $(\mathrm{Pu}, \mathrm{U}) \mathrm{O}_{2}{ }^{a}$ & $\begin{array}{l}\mathrm{UO}_{2} \\
\text { Fines }\end{array}$ & $\begin{array}{c}\text { Axlal Blanket } \\
\mathrm{UO}_{2} \text { Pellets }\end{array}$ & $(\mathrm{Pu}, \mathrm{v}) \mathrm{O}_{2}$ & $\begin{array}{l}\mathrm{UO}_{2} \\
\text { Fines }\end{array}$ & $\underset{\mathrm{VO}_{2}}{\mathrm{Ax \perp al}}$ & $\begin{array}{l}1 \text { Blanket } \\
\text { Pellets }\end{array}$ \\
\hline Receiving and storage & 1051.3 & $276.9^{d}$ & 737.9 & & & & & & & \\
\hline Sampling and batch loading & 1050.2 & & & & & & 1.1 & & & \\
\hline We1ghing and sampling & & 276.6 & $737.2^{e}$ & & & & & 0.3 & & 0.7 \\
\hline Calcining and sintering & 1049.7 & & & & & & 0.5 & & & \\
\hline Sphere upgrading & $1108.7^{f}$ & & & & & & 31.5 & & & \\
\hline Sphere sampling & 1106.5 & & & & & & 2.2 & & & \\
\hline Inter1m storage & 1106.5 & 276.6 & 401.9 & & & & & & & \\
\hline Fuel rod loading & 1106.5 & 276.6 & 401.9 & & & & & & & \\
\hline Fuel rod scanning & 1051.2 & 262.8 & $763.6^{9}$ & 53.1 & 13.3 & 19.3 & 2.2 & 0.6 & & 0.8 \\
\hline Top component insertion & 1048.9 & 262.2 & 762.0 & 2.1 & 0.5 & 1.5 & 0.2 & 0.1 & & 0.2 \\
\hline Rod welding and $x$ ray & 1048.9 & 262.2 & 762.0 & $h$ & $h$ & $h$ & $h$ & $h$ & & $h$ \\
\hline Leak detection & 1048.9 & 262.2 & 762.0 & $h$ & $h$ & $h$ & h & $h$ & & $h$ \\
\hline Rod assay & 1027.9 & 257.0 & 746.7 & 19.9 & 5.0 & 14.5 & 1.0 & 0.3 & & 0.8 \\
\hline Final rod inspection & 1017.2 & 254.3 & 738.9 & 10.3 & 2.6 & 7.5 & 0.4 & 0.1 & & 0.3 \\
\hline Assembly Inspection & 1011.9 & 253.0 & 735.1 & 5.1 & 1.3 & 3.7 & 0.2 & $\underline{0.1}$ & & $\underline{0.1}$ \\
\hline Total & & 2000 & & 90.5 & 22.7 & 46.5 & 39.3 & 1.3 & & 2.9 \\
\hline
\end{tabular}

$a_{11.82}$ and $17.67 \%$ average fissile plutontum contents in zones 1 and 2 , respectively

internally recycled.

collected, assayed, and externally recycled to reprocessing plant.

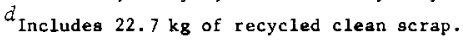

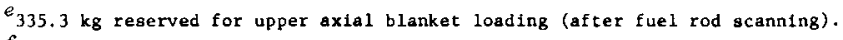

$f_{\text {Includes }} 90.5 \mathrm{~kg}$ of recycled clean scrap.

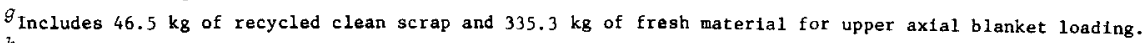

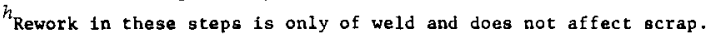


Table 9.74. Equipment Requirements for Functional Areas (NASAP Case 6.3.1 LMFBR U-Pu/Th Splked Recycle, Westınghouse Transmuter, Heterogeneous Core Design)

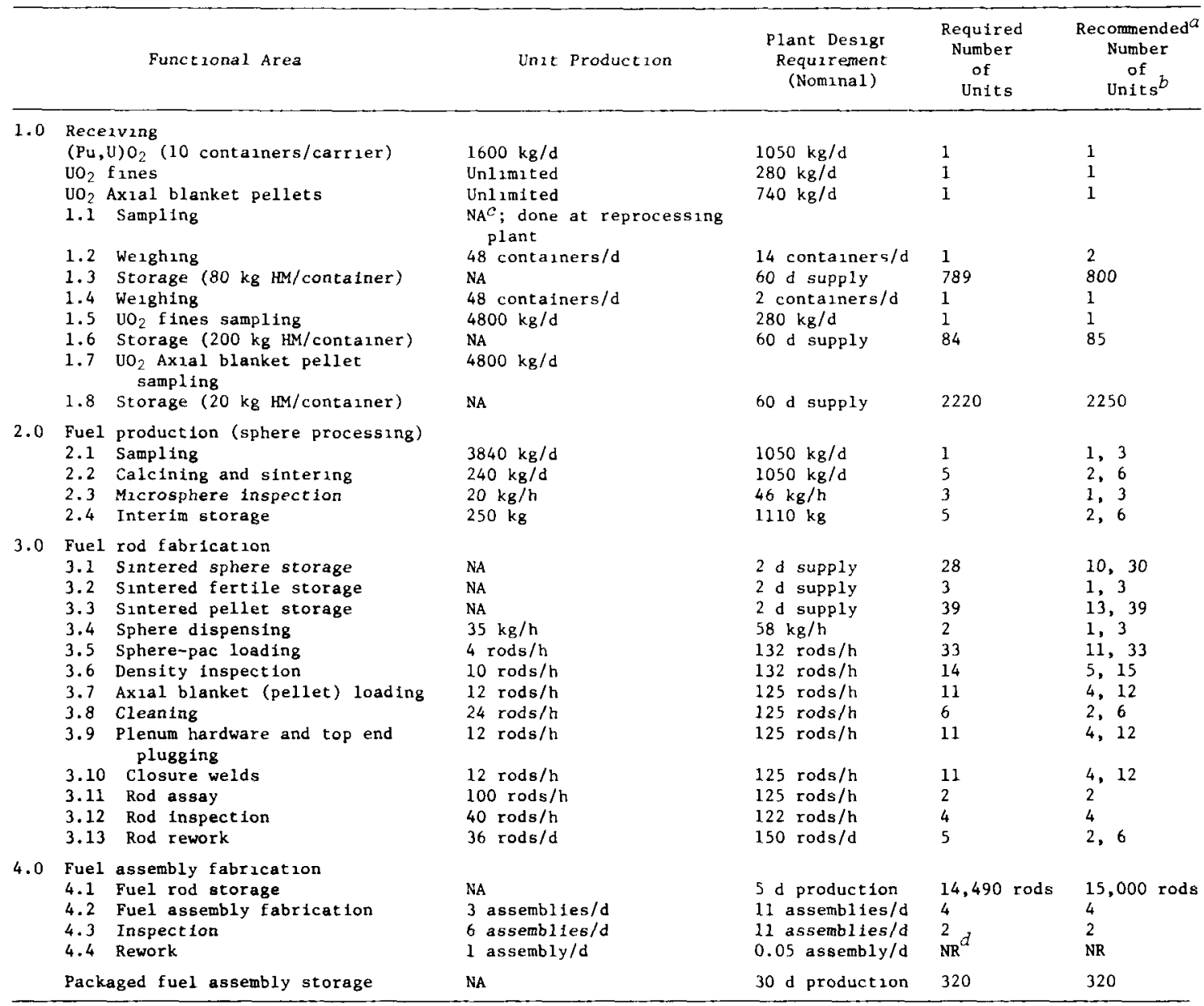

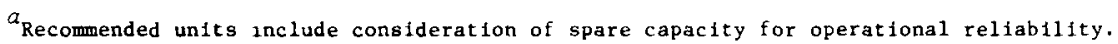

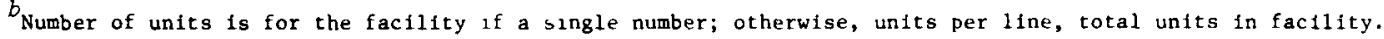
NA: not applicable.

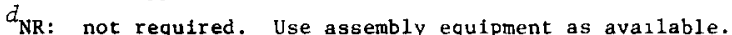


development needs are summarized in Table 9.75. The primary difference between this $\mathrm{U}-\mathrm{Pu}$ fuel and the reference $\mathrm{U}-\mathrm{Pu}$ fuel is the much higher concentration of plutonium. Development is under way in the United States on sphere forming, calcination, and sintering of $(\mathrm{U}, \mathrm{Pu}) \mathrm{O}_{2}$ with $\mathrm{Pu} / \mathrm{U}$ ratios adequate for both the reference case and the fast reactor fuels.

While the functional fabrication processes are the same as those given for the reference ge1-sphere-pac fabrication case, the design of the LMFBR fuel elements is considerably different. These differences in design result in modifications to the details for accomplishing the various functional activities and modifications to the facility design details. In the subsequent paragraphs, each of the functional activities is discussed as it applies to this case.

A ge1-sphere-pac functional flow diagram is given in Fig. 3.1 of Sect. 3.1.1 of this report. The major functional areas apply to this case, and the two main functions unique to the ge1-sphere-pac process are fuel production (2.0) and fuel rod fabrication (3.0). All the functional steps are briefly discussed here.

Receiving and Storage. This functional area is quite similar to the reference case. However, in addition to the spheres, the $\mathrm{UO}_{2}$ axial blanket pellets must be received, inspected, and stored.

Fuel Production. The fuel production processes for the spheres are essentially the same as those described for the reference case including calcination, sintering, and inspection of the coarse and medium sizes, which contain plutonium. No processing is planned for the $\mathrm{UO}_{2}$ fines because they are to be sintered at the reprocessing conversion step. However, because the $\mathrm{UO}_{2}$ axial blanket pellets make up approximately $37 \%$ of the total heavy metal content in a core fuel assembly, the quantity of coarse and medium spheres processed is significantly less than in the reference case.

Fuel Rod Fabrication. While most of the fuel rod fabrication processes are similar to the reference case, additional steps are required to incorporate the axial blanket material. The lower axial blanket section is loaded into the fuel rod cladding before the cladding is introduced into the cell. After the $(\mathrm{U}, \mathrm{Pu}) \mathrm{O}_{2}$ core region is loaded by the sphere-pac process into each rod and inspected for density the upper axial blanket section will be loaded by equipment similar to that used for inserting 
Table 9.75. Research and Development Cost Estimates for Sphere-Pac Fabrication [NASAP Case 6.3.1, LMFBR U-Pu/Th Spiked Recycle, Westinghouse Transmuter; Heterogeneous Core Design]

\begin{tabular}{|c|c|c|c|c|}
\hline & R\&D Categories & Current Status ${ }^{a}$ & $\begin{array}{c}\text { R\&D Cost Estimates } \\
\text { (Millions of } \\
1978 \$)\end{array}$ & $\begin{array}{l}\text { Years to } \\
\text { Complete }\end{array}$ \\
\hline 1.0 & Program management & Not applicable & 10 & 10 \\
\hline 2.0 & Design studies & $\mathrm{N}-$ cold engineering & 25 & 10 \\
\hline 3.0 & Receiving and storage & $P$ - cold engineering & 4 & 5 \\
\hline 4.0 & Fuel production & $P$ - hot engineering & 25 & 6 \\
\hline 5.0 & Fuel rod fabrication & $P-$ cold engineering & 50 & 8 \\
\hline 6.0 & Fuel element assembly & $\mathrm{N}-$ cold engineering & 27 & 8 \\
\hline 7.0 & Scrap recovery & $\mathrm{N}-\operatorname{cold}$ engineering & 3 & 5 \\
\hline 8.0 & Waste treatment & $b$ & $b$ & $b$ \\
\hline 9.0 & Plant control systems & $\mathrm{N}$ - cold prototype & 5 & 8 \\
\hline 10.0 & Maintenance & $\mathrm{N}-\operatorname{cold}$ prototype & 5 & 10 \\
\hline 11.0 & $\begin{array}{l}\text { Safeguards and account- } \\
\text { ability adaptation }\end{array}$ & $P-c o l d$ engineering & 6 & 6 \\
\hline & Subtotal & & 160 & \\
\hline \multicolumn{5}{|c|}{ Special Facilities } \\
\hline \multicolumn{2}{|c|}{ Hot tests } & & 10 & \\
\hline \multicolumn{2}{|c|}{ Cold prototype } & & 25 & \\
\hline & Total & & $195^{d}$ & \\
\hline & Range & & $185-235$ & \\
\hline $\begin{array}{l}\mathrm{N}=\mathrm{n} \\
\mathrm{appli} \\
\mathrm{milli}\end{array}$ & $\begin{array}{l}a_{\text {Status stage with qualit }} \\
\text { eeded. } \\
b_{\text {To be supplied by others }} \\
c_{\text {Assumes basic technology }} \\
\text { cations testing, systems } \\
d_{\text {The estimate does not in }} \\
\text { on) or the capital costs }\end{array}$ & $\begin{array}{l}\text { ive modifiers; } C=\text { cor } \\
\text { s developed under oss } \\
\text { tegraton, and testing } \\
\text { ude costs for fuel qua } \\
\text { a pilot plant estimat }\end{array}$ & $\begin{array}{l}\text { lete, } P=\text { in progre } \\
\text { stimate presented } \\
\text { ification tests } \\
\text { d at } \$ 160 \text { million. }\end{array}$ & $\begin{array}{l}\text { s, and } \\
\text { for } \\
\text { ut } \$ 20\end{array}$ \\
\hline
\end{tabular}


plenum hardware. The actual plenum hardware insertion and end cap welding operations are essentially the same as those described for the reference case.

Fuel Assembly Operations. The fuel assembly design for this LMFBR case 6.3.1 is identical to that for the pellet fabrication option. Following fuel rod inspection each rod will be remotely wrapped with a wire. This special wire wrap will space the fuel rods in the assembly. Groups of these rods are assembled onto T-bars of varying length. The $T$-bar strip layers are assembled and fastened to the lower end box of the fuel assembly. The duct tube is installed and the finished assembly is inspected.

Product Control Processes. These are the same as the reference case (see Sect. 4.1.2).

Scrap and Waste Processing and Disposal. The scrap handling processes are similar to the reference case (see Sect.4.1.2) with the added feature that all axial blanket pellets that are unloaded from an unsatisfactory rod are inspected, and acceptable pellets are recycled within the remotely operated part of the facilities to form upper axial blankets.

\subsubsection{Preliminary Cost Estimate for Construction and Operation of a Commercial-Scale Plant}

The cost components that were estimated include capital costs for the facility and equipment, fuel assembly hardware costs, material and supply costs, and operating costs.

Facility capital cost estimates were based on an analysis of the functional flow diagram for the process to indicate space requirements for each functional area and for each support area. Equipment requirements were identified, and costs associated with the equipment were estimated. Fuel assembly hardware requirements were based on the reference fuel assembly design parameters identified in Table 9.71. Estimates of the costs of the hardware items were obtained. Material and supply requirements were identified from the sphere-pac process description, and estimates of the costs of materials and supplies were obtained. Operating cost estimates included consideration of personnel, overhead, general and administrative expenses, and costs of utilities. 
The facility was assumed to operate as a toll processing facility. That is, the operator fabricates customer-supplied fuel feed materials into finished fuel assemblies, and thus costs of plutonium, uranium, and thorium were not included in the cost estimates. The hardware and material costs do include the costs associated with the production of the $\mathrm{UO}_{2}$ pellets for the axial blanket.

Unit costs for fabrication of fuel assemblies are determined by an economic analysis of the basic capital, hardware and material, and operating cost estimates. Basically, the economic analysis provides for the owner of the fuel fabrication facility to recover all capital, operating, and finance charges plus a return on investment, if appropriate, over the life of the plant.

In order to provide a range of prices (i.e., costs to a customer), economic analyses were based on government financing, financing appropriate for a conventional-risk (typical) industry, and financing appropriate for a high-risk industry. 2 The estimated costs, costs derived from the economic analysis, and the unit costs based on the three different financing methods are summarized in Table 9.76. As may be observed from the table, the price for fabrication of $(\mathrm{U}, \mathrm{Pu}) \mathrm{O}_{2}-\mathrm{UO}_{2}$ fuel is expected to be in the range from $\$ 370$ to $\$ 710 / \mathrm{kg}$ depending on the financing technique that is employed. The recommended cost for comparison with other fuel cycles and methods of fabrication is the typical industry cost of $\$ 570 / \mathrm{kg}$ of heavy metal. As with all the cost estimates in this report, the prices are based on the mass of all heavy metal in the finished assembly. For this case, this includes the uranium in the axial blankets. 
Table 9.76. Summary of Costs for Fabrication of Sphere-Pac PWR Fuel in a 2-t HM/d Facility [NASAP Case 6.3.1 LMFBR U-Pu/Th Spiked Recycle, (Westinghouse Transmuter) Heterogeneous Core Design]

\begin{tabular}{|c|c|c|c|c|c|c|c|c|c|}
\hline \multirow[b]{2}{*}{$\begin{array}{l}\text { Economic } \\
\text { Set }\end{array}$} & \multicolumn{4}{|c|}{ Estimated Costs, \$million } & \multicolumn{4}{|c|}{ Derived Costs, \$ million } & \multirow[b]{2}{*}{$\begin{array}{l}\text { Unit } \\
\text { Cost } b \\
(\$ / \mathrm{kg})\end{array}$} \\
\hline & Facility & Equipment & $\begin{array}{l}\text { Annual } \\
\text { Hardware } \\
\text { Plus } \\
\text { Materials }\end{array}$ & $\begin{array}{c}\text { Annual } \\
\text { Operating }\end{array}$ & $\begin{array}{l}\text { Owner's } \\
\text { Cost } \\
\text { During } \\
\text { Construction }\end{array}$ & $\begin{array}{c}\text { Charge on } \\
\text { Direct Capital } \\
\text { During } \\
\text { Construction }\end{array}$ & $\begin{array}{c}\text { Annual } \\
\text { Equipment } \\
\text { Replacement } \\
\text { Cost }\end{array}$ & $\begin{array}{c}\text { Annual } \\
\text { Payment to } \\
\text { Decommissioning } \\
\text { Fund }\end{array}$ & \\
\hline A & 260 & 255 & 60 & 27 & 39 & 140 & 13 & 1.2 & 370 \\
\hline B & 260 & 255 & 60 & 28 & 40 & 200 & 13 & 1.3 & 570 \\
\hline $\mathrm{c}$ & 260 & 255 & 60 & 29 & 41 & 200 & 13 & 1.3 & 710 \\
\hline
\end{tabular}

$a_{A}=$ Government financing; $B=$ Typical industrial financing; $c=$ High-risk industrial financing.

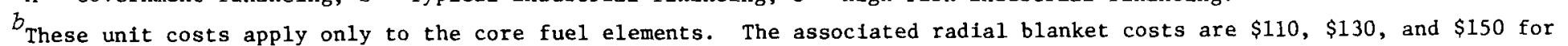
economic sets $A, B$, and $C$, respectively. 
9.17 NASAP CASE 6.3.2, LMFBR U-Pu/Th, SPIKED RECYCLE, GENERAL ELECTRIC TRANSMUTER, HOMOGENEOUS CORE DESIGN

\subsubsection{Fuel Cycle Description}

This reactor-fuel cycle combination is an LMFBR using a homogeneous core of U-Pu and axial and radial blankets of thorium oxide. Core assemblies are preirradiated for spiking before shipment. Core assemblies are coprocessed, and all the recovered uranium and plutonium are recycled to fabrication. Makeup plutonium from secure storage and depleted uranium are mixed with the recycled U-Pu as feed to core fabrication. Blanket assemblies are fabricated from new thorium. The $233_{U}$ recovered during blanket reprocessing is denatured with the addition of depleted uranium in process and sent to safe storage. The recovered thorium is stored for ten years.

In this cycle analysis only fabrication of the core assemblies is considered. The required makeup plutonium and depleted uranium are assumed to be mixed with the highly decontaminated coprocessed $(\mathrm{U}, \mathrm{Pu}) \mathrm{O}_{2}$ in the reprocessing plant before conversion. The reprocessing plant will thus supply the coarse and medium sizes of spherical particles with the appropriate $\mathrm{U} / \mathrm{Pu}$ ratio in the as-dried condition and the $\mathrm{UO}_{2}$ fine particles as fully sintered spheres. The $\mathrm{ThO}_{2}$ pellets for the axial blanket regions in these assemblies will be supplied from an adjacent contactoperated and contact-maintained ( $\mathrm{CO} / \mathrm{CM}$ ) facility where the radial blanket assemblies are fabricated.

The extended burnup of the recycle plutonium will cause significant radioactivity in the $(\mathrm{U}, \mathrm{Pu})_{2}$ core materials. Consequently, a remotely operated and contact-maintained (RO/CM) facility has been addressed in this analysis. However, it is fully recognized that any crossover of the $233 \mathrm{U}$ bred in the axial blankets into the core (U, Pu) stream would significantly increase the radioactivity of the $(\mathrm{U}, \mathrm{Pu}) \mathrm{O}_{2}$ materials. Such a situation would probably require a remotely operated and remotely maintained (RO/RM) facility. This would significantly increase the facility capital and operating costs but would not alter the basic fabrication process requirements. 


\subsubsection{Applicability to Current Fuel Element Design}

The core fuel element design chosen for this cycle is given in Table 9.77.

The key considerations for sphere-pac applicability are the cladding inside diameter measurements and the required fuel smear density. The cladding ID of $6760 \mu \mathrm{m}$ in the reference design is suitable for the spherepac process. Although the specified smear density of $90 \%$ of theoretical is above that currently achieved with experimental blended (three particle size) sphere-pac beds, we have assumed that the process is applicable through a slight lowering of this design requirement.

\subsubsection{Definition of Plant Production Requirements and Design Capacity}

For this LMFBR (U, $\mathrm{Pu})_{2}-\mathrm{ThO}_{2}$ fuel cycle, the plant design assumptions are listed below. The heavy metal through-put for this plant and all cases involving axial blanket fuel is based on the total heavy metal in the finished fuel assembly, in both core and axial blanket.

1. The fuel design is the General Electric Company Advanced Reactor Systems Department homogeneous reactor fuel design.

2. The plant production capacity is $480 \mathrm{t} H \mathrm{H} /$ year with the capability for simultaneous production of three enrichments.

3. The plant factor is 240 effective full-production days per year.

4. Plant design capacity: Overa11

$730 \mathrm{t} \mathrm{HM} /$ year about 13 fuel assemblies/d

Each line of three $243 \mathrm{t} \mathrm{HM} /$ year

$0.67 \mathrm{t} \mathrm{HM} / \mathrm{d}$

1119 fuel rods/d

4.1 fuel assemblies/d

5. Process design capacities are based on the line design capacities and the scrap and sample losses defined in Sect. 9.17.4.

6. The facilities are designed to discharge no liquid waste other than treated sanitary sewage. 
Table 9.77. Sumary of General Electric Transmuter LMFBR Fuel Assembly Parameters (NASAP Case 6.3.2, LMFBR U-Pu/Th, Spiked Recycle, Homogeneous Core Design)

\begin{tabular}{|c|c|c|}
\hline \multicolumn{3}{|c|}{ Reactor Characteristics } \\
\hline & 1000 MWe (net) & \\
\hline Fuel assemblies & 252 (150 zone $1 ; 102$ zone 2$)$ & \\
\hline Inner blanket assemblies & Not applicable & \\
\hline Radial blanket assemblies & 198 & \\
\hline Control assemblies & 19 & \\
\hline Removable shield assemblies & 240 & \\
\hline Fissile enrichment, \% & Zone $1-10.24 ;$ Zone $2,-14.36$ & \\
\hline Component Characteristics & $\begin{array}{cc} & \text { Number per } \\
\text { Material } & \text { Fuel Assembly }\end{array}$ & $\begin{array}{l}\text { Mass (kg) per } \\
\text { Fuel Assemb1y }\end{array}$ \\
\hline & End plugs & \\
\hline Top & Improved $316 \mathrm{sS}$ & \\
\hline Bottom & Improved 316 SS & \\
\hline \multicolumn{3}{|l|}{ Reflector rods } \\
\hline \multicolumn{3}{|l|}{ Plenum springs } \\
\hline \multicolumn{3}{|l|}{ Spacers } \\
\hline Wire wrap & 316 SS & \\
\hline \multicolumn{3}{|l|}{ Attachment rails } \\
\hline \multicolumn{3}{|l|}{ Locking pins } \\
\hline Shield and inlet assemblies & Improved $316 \mathrm{SS}$ & \\
\hline $\begin{array}{l}\text { Duct and upper handling } \\
\text { socket }\end{array}$ & Improved $316 \mathrm{sS}$ & \\
\hline \multicolumn{3}{|l|}{ Fuel Rod Characteristics } \\
\hline \multirow{2}{*}{\multicolumn{3}{|c|}{$\begin{array}{ll}\text { Fuel cladding outside diameter } & 7.37 \mathrm{~mm}(0.290 \text { in.) } \\
\text { Fuel cladding inside diameter } & 6.76 \mathrm{~mm}(0.266 \text { in.) }\end{array}$}} \\
\hline & $6.76 \mathrm{~mm}(0.266 \mathrm{in.})$ & \\
\hline Fue1 rod length & $2.85 \mathrm{~cm}$ (112 in.) & \\
\hline \multicolumn{3}{|c|}{ Plenum length } \\
\hline Upper & $914.4 \mathrm{~mm}$ ( $36.0 \mathrm{in.})$ & \\
\hline Lower & Not applicable & \\
\hline Core fuel height & $1219 \mathrm{~mm}(48.0 \mathrm{in.})$ & \\
\hline \multicolumn{3}{|l|}{ Axial blanket height } \\
\hline Upper & $356 \mathrm{~mm}(14.0$ in. $)$ & \\
\hline Lower & $356 \mathrm{~mm}(14.0 \mathrm{in.})$ & \\
\hline \multicolumn{3}{|l|}{ Pellet density } \\
\hline Fuel smear density & $90 \%$ T.D. & \\
\hline Pellet diameter & $6.62 \mathrm{~mm}(0.2605 \mathrm{in.})$ & \\
\hline \multicolumn{3}{|l|}{ Pellet length } \\
\hline \multirow{2}{*}{$\begin{array}{l}\text { Wire wrap diameter } \\
\text { Bonding }\end{array}$} & $1.44 \mathrm{~mm}(0.0567 \mathrm{in.})$ & \\
\hline & He & \\
\hline \multicolumn{3}{|l|}{ Fuel Assembly Characteristics } \\
\hline Array & Hexagonal & \\
\hline \multicolumn{3}{|l|}{ Fuel assembly length } \\
\hline Duct outside flat-to-flat & $154.5 \mathrm{~mm}(6.083 \mathrm{in.})$ & \\
\hline Duct wall thickness & $3.18 \mathrm{~mm}(0.125 \mathrm{in.})$ & \\
\hline \multicolumn{3}{|l|}{ Mass of structural components } \\
\hline \multicolumn{3}{|l|}{ Heavy metal content } \\
\hline Core & $103.74 \mathrm{~kg}$ & \\
\hline Axial blanket & $57.75 \mathrm{~kg}$ & \\
\hline
\end{tabular}


7. All process buildings and critical auxiliary support are designed and constructed in accordance with current United States Nuclear Regulatory Commission licensing requirements. Shielding is provided to limit dose rates to operating and maintenance personnel to $0.25 \mathrm{millirem} / \mathrm{h}$.

In addition, we assumed that production from each fuel rod line is campaigned to provide a full reload segment for a single 1000-MWe LMFBR. Thus, the total heavy metal output for a given campaign is $20.3 \mathrm{t}$, and each campaign requires 30.5 effective full-production days ( 46 calendar days). The total facility, with an adjacent radial blanket assembly plant, can support approximately 29 such reactors.

9.17.4 Estimates of Surge Storage Requirements, Scrap Production Rates, and Processing Rates for Functional Steps

Given the plant design assumptions defined in Sect.9.17.3, further commercial plant characteristics were derived.

To achieve the annual production rates, an analysis of the plant surge storage requirements and normal inventory was made, and the results of this analysis are given in Table 9.78.

Based on current technology and assuming reasonable extrapolations for commercial-scale developments, a preliminary estimate was made of the daily mass flows of heavy metal through the fabrication plant and the average production rate of heavy metal scrap materials from the various functional activities. These are presented in Table 9.79.

Given the above information, a preliminary evaluation of the processing rate for each functional step within the main fuel fabrication processes was made. The results of this analysis are summarized in Table 9.80 .

\subsubsection{Analysis of Functional Technology Status, Research and Development Requirements, Cost, and Schedule}

The technology status of this system is quite similar to that of the reference case discussed in Sect. 8. The current status and research and development needs are summarized in Table 9.81. The primary difference 
Table 9.78. Sphere-Pac Fabrication Plant Surge Storage Requirements and Normal Inventory [NASAP Case 6.3.2, LMFBR U-Pu/Th Spiked Recycle (GE Transmuter) -

Homogeneous Core Design]

\begin{tabular}{|c|c|c|c|c|c|c|}
\hline \multirow{2}{*}{ Process step } & \multirow{2}{*}{ Material } & \multicolumn{2}{|c|}{$\begin{array}{l}\text { Storage } \\
\text { Interval, } d\end{array}$} & \multicolumn{3}{|c|}{ Normal Inventory, $\mathrm{kg} \mathrm{HM}$} \\
\hline & & Normal & Maximum & $(\mathrm{Pu}, \mathrm{U}) \mathrm{O}_{2}$ & $\mathrm{UO}_{2}$ Fines & $\mathrm{ThO}_{2}$ Pellets \\
\hline Feed storage & $\begin{array}{l}\text { Dried spheres } \\
\text { Sintered spheres } \\
\text { Sintered pellets }\end{array}$ & $\begin{array}{l}30 \\
30 \\
30\end{array}$ & $\begin{array}{l}60 \\
60 \\
60\end{array}$ & 32,000 & 8,440 & 21,540 \\
\hline Interim storage & $\begin{array}{l}\text { Dried spheres } \\
\text { Sintered spheres } \\
\text { Sintered pellets }\end{array}$ & $\begin{array}{l}1 \\
1 \\
1\end{array}$ & $\begin{array}{l}2 \\
2 \\
2\end{array}$ & 1,130 & 280 & 390 \\
\hline Furnace & $\begin{array}{l}\text { Dried to sintered } \\
\text { spheres }\end{array}$ & 1.2 & 2.4 & 1,360 & & \\
\hline Post furnace & Sintered spheres & 0.5 & 1 & 570 & & \\
\hline Interim storage & Sintered spheres & 0.36 & 0.72 & 410 & & \\
\hline Main storage & $\begin{array}{l}\text { Sintered spheres } \\
\text { Sintered spheres } \\
\text { Sintered pellets }\end{array}$ & $\begin{array}{l}1.2 \\
1.5 \\
1.5\end{array}$ & $\begin{array}{l}2.4 \\
2.9 \\
2.9\end{array}$ & 1,360 & 420 & 590 \\
\hline $\begin{array}{l}\text { Loading, inspection, } \\
\text { welding }\end{array}$ & $\begin{array}{l}\text { Sintered spheres } \\
\text { and pellets }\end{array}$ & 0.12 & 0.24 & 230 & 30 & 45 \\
\hline $\begin{array}{l}\text { Loaded, not inspected } \\
\text { rods }\end{array}$ & $\begin{array}{l}\text { Sintered spheres } \\
\text { in rods }\end{array}$ & 5 & 5 & 5,330 & 1,330 & 3,710 \\
\hline Rework and scrap & $\begin{array}{l}\text { Sintered spheres } \\
\text { and pellets }\end{array}$ & 2 & 5 & 200 & 50 & 90 \\
\hline Completed fuel rods & $\begin{array}{l}\text { Sintered spheres } \\
\text { and pellets } \\
\text { in rods }\end{array}$ & 5 & 5 & 5,170 & 1,290 & 3,600 \\
\hline Assembly & $\begin{array}{l}\text { Rods in completed } \\
\text { assemblies }\end{array}$ & 15 & 30 & 15,420 & 3,860 & 10,730 \\
\hline
\end{tabular}


Table 9.79. Heavy Metal Mass Flows and Average Scrap Production for a Sphere-Pac Fuel Fabrication Plant (NASAP Case 6.3.2, LMFBR U-Pu/Th, Spiked Recycle, GE Transmuter, Homogeneous Core Design)

\begin{tabular}{|c|c|c|c|c|c|c|c|c|c|}
\hline \multirow{3}{*}{ Processing Step } & \multicolumn{9}{|c|}{ Mass Flow, $\mathrm{kg} \mathrm{HM} / \mathrm{d}$} \\
\hline & \multicolumn{3}{|c|}{ Daily Throughput } & \multicolumn{3}{|c|}{ Clean Scrap $b$} & \multicolumn{3}{|c|}{ Reject Scrape } \\
\hline & $(\mathrm{Pu}, \mathrm{U}) \mathrm{O}_{2}{ }^{\alpha}$ & $\begin{array}{l}\mathrm{UO}_{2} \\
\text { Fines }\end{array}$ & $\begin{array}{l}\text { Axial Blanket } \\
\mathrm{ThO}_{2} \text { Pellets }\end{array}$ & $(\mathrm{Pu}, \mathrm{U}) \mathrm{O}_{2}^{a}$ & $\begin{array}{l}\mathrm{UO}_{2} \\
\text { Fines }\end{array}$ & $\begin{array}{l}\text { Axial Blanket } \\
\mathrm{ThO}_{2} \text { Pellets }\end{array}$ & $(\mathrm{Pu}, \mathrm{U}) \mathrm{O}_{2}{ }^{\alpha}$ & $\begin{array}{l}\mathrm{UO}_{2} \\
\text { Fines }\end{array}$ & $\begin{array}{l}\text { Axial Blanket } \\
\mathrm{ThO}_{2} \text { Pellets }\end{array}$ \\
\hline Receiving and storage & 1068.0 & $281.3^{d}$ & 717.9 & & & & & & \\
\hline Sampling and batch loading & 1066.9 & & & & & & 1.1 & & \\
\hline Weighing and sampling & & 281.0 & $717.2^{e}$ & & & & & 0.3 & 0.7 \\
\hline Calcining and sintering & 1066.4 & & & & & & 0.5 & & \\
\hline Sphere upgrading & $1126.2^{f}$ & & & & & & 32.0 & & \\
\hline Sphere sampling & 1123.9 & & & & & & 2.3 & & \\
\hline Interim storage & 1123.9 & 281.0 & 391.0 & & & & & & \\
\hline Fuel rod loading & 1123.9 & 281.0 & 391.0 & & & & & & \\
\hline Fue1 rod scanning & 1067.7 & 266.9 & 743.09 & 53.9 & 13.5 & 18.8 & 2.2 & 0.6 & 0.8 \\
\hline Top component insertion & 1065.4 & 266.3 & 741.3 & 2.1 & 0.5 & 1.5 & 0.2 & 0.1 & 0.1 \\
\hline Leak detection & 1065.4 & 266.3 & 741.3 & $h$ & $h$ & $h$ & $h$ & $h$ & $h$ \\
\hline Rod assay & 1044.1 & 261.0 & 726.5 & 20.2 & 5.1 & 14.1 & 1.1 & 0.3 & 0.7 \\
\hline Final rod inspection & 1033.2 & 258.3 & 719.0 & 10.4 & 2.6 & 7.3 & 0.4 & 0.1 & 0.3 \\
\hline Assembly inspection & 1027.8 & 257.0 & 715.2 & 5.2 & 1.3 & 3.6 & 0.2 & $\underline{0.1}$ & $\underline{0.1}$ \\
\hline Total & & 2000 & & 91.8 & 23.0 & 45.3 & 40.0 & 1.3 & 2.7 \\
\hline
\end{tabular}

$a_{10.24}$ and $14.36 \%$ average fissile plutonium contents in Zones 1 and 2 , respectively.

$b_{\text {Internally recycled. }}$

${ }^{c}$ Collected, assayed, and externally recycled to reprocessing plant.

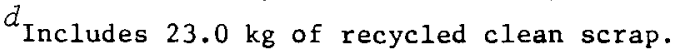

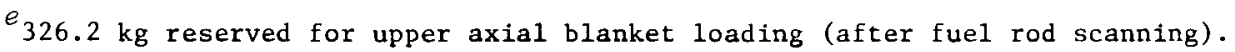

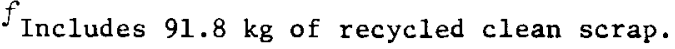

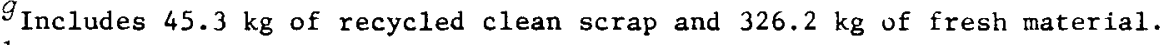

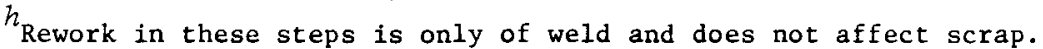


Table 9.80. Equipment Requirements for Functional Areas (NASAP Case 6.3.2 LMFBR U-Pu/Th, Spiked Recycle,

GE Transmuter, Homogeneous Core Design)

\begin{tabular}{|c|c|c|c|c|c|}
\hline & Functional Area & Unit Production & $\begin{array}{l}\text { Plant Design } \\
\text { Requirement } \\
\text { (Nomina1) }\end{array}$ & $\begin{array}{c}\text { Required } \\
\text { Number } \\
\text { of } \\
\text { Units }\end{array}$ & $\begin{array}{c}\text { Recommended } a \\
\text { Number } \\
\text { of } \\
\text { Units } b\end{array}$ \\
\hline \multirow[t]{8}{*}{1.0} & $\begin{array}{l}\text { Recelving } \\
\text { ( } \mathrm{Pu}, \mathrm{U}) \mathrm{O}_{2} \text { ( } 10 \text { containers/carrier) } \\
\mathrm{UO}_{2} \text { fines } \\
\mathrm{ThO}_{2} \text { Axial blanket pellets } \\
\mathrm{l} .1 \text { Sampling }\end{array}$ & $\begin{array}{l}1600 \mathrm{~kg} / \mathrm{d} \\
\text { Unlimited } \\
\text { Unlimited } \\
\text { NA }{ }^{c} \text {; done at reprocessing } \\
\text { plant }\end{array}$ & $\begin{array}{l}1030 \mathrm{~kg} / \mathrm{d} \\
280 \mathrm{~kg} / \mathrm{d} \\
720 \mathrm{~kg} / \mathrm{d}\end{array}$ & $\begin{array}{l}1 \\
1 \\
1\end{array}$ & $\begin{array}{l}1 \\
1 \\
1\end{array}$ \\
\hline & 1.2 Weighing & 48 containers/d & 14 containers/d & 1 & 2 \\
\hline & 1.3 Storage ( $80 \mathrm{~kg} \mathrm{HM} /$ container) & NA & $60 \mathrm{~d}$ supply & 801 & 810 \\
\hline & 1.4 Weighing & 48 containers/d & 2 containers $/ \mathrm{d}$ & 1 & 1 \\
\hline & $1.5 \mathrm{UO}_{2}$ fines sampling & $4800 \mathrm{~kg} / \mathrm{d}$ & $280 \mathrm{~kg} / \mathrm{d}$ & 1 & 1 \\
\hline & 1.6 Storage ( $200 \mathrm{~kg} \mathrm{HM} /$ contatner) & NA & 60 d supply & 85 & 85 \\
\hline & $\begin{array}{l}\text { 1.7 } \mathrm{ThO}_{2} \text { Axial blanket pellet } \\
\text { sampling }\end{array}$ & $4800 \mathrm{~kg} / \mathrm{d}$ & $720 \mathrm{~kg} / \mathrm{d}$ & 1 & 1 \\
\hline & 1.8 Storage $(20 \mathrm{~kg} \mathrm{HM} /$ container $)$ & NA & $60 \mathrm{~d}$ supply & 2160 & 2200 \\
\hline 2.0 & $\begin{array}{l}\text { Fuel production (sphere processing) } \\
2.1 \text { Sampling } \\
2.2 \text { Calcining and sintering } \\
2.3 \text { Microsphere inspection } \\
2.4 \text { Interim storage }\end{array}$ & $\begin{array}{l}3840 \mathrm{~kg} / \mathrm{d} \\
240 \mathrm{~kg} / \mathrm{d} \\
20 \mathrm{~kg} / \mathrm{h} \\
250 \mathrm{~kg}\end{array}$ & $\begin{array}{l}1070 \mathrm{~kg} / \mathrm{d} \\
1070 \mathrm{~kg} / \mathrm{d} \\
47 \mathrm{~kg} / \mathrm{h} \\
1120 \mathrm{~kg} / \mathrm{d}\end{array}$ & $\begin{array}{l}1 \\
5 \\
3 \\
5\end{array}$ & $\begin{array}{l}1,3 \\
2,6 \\
1,3 \\
2,6\end{array}$ \\
\hline 3.0 & Fuel rod fabrication & & & & \\
\hline & 3.1 Sintered sphere storage & NA & $2 \mathrm{~d}$ supply & 28 & 10,30 \\
\hline & 3.2 Sintered fertile storage & NA & 2 d supply & 3 & 1,3 \\
\hline & 3.3 Sintered pellet storage & NA & 2 d supply & 38 & 13,39 \\
\hline & 3.4 Sphere dispensing & $35 \mathrm{~kg} / \mathrm{h}$ & $59 \mathrm{~kg} / \mathrm{h}$ & 2 & 1,3 \\
\hline & 3.5 Sphere-pac loading & $4 \operatorname{rod} s / h$ & $153 \mathrm{rods} / \mathrm{h}$ & 39 & 13,39 \\
\hline & 3.6 Density inspection & $10 \mathrm{rods} / \mathrm{h}$ & $153 \mathrm{rods} / \mathrm{h}$ & 16 & 6,24 \\
\hline & 3.7 Axial blanket (pellet) loading & $12 \mathrm{rods} / \mathrm{h}$ & $146 \mathrm{rods} / \mathrm{h}$ & 13 & 5,15 \\
\hline & 3.8 Cleaning & $24 \mathrm{rods} / \mathrm{h}$ & $146 \mathrm{rods} / \mathrm{h}$ & 7 & 3,9 \\
\hline & $\begin{array}{l}\text { 3.9 Plenum hardware and top end } \\
\text { pluggtng }\end{array}$ & $12 \operatorname{rods} / \mathrm{h}$ & $146 \mathrm{rods} / \mathrm{h}$ & 13 & 5,15 \\
\hline & 3.10 closure welds & $12 \mathrm{rods} / \mathrm{h}$ & $146 \mathrm{rods} / \mathrm{h}$ & 13 & 5,15 \\
\hline & 3.11 Rod assay & $100 \mathrm{rods} / \mathrm{h}$ & $146 \mathrm{rods} / \mathrm{h}$ & 2 & 2 \\
\hline & 3.12 Rod inspection & $40 \mathrm{rods} / \mathrm{h}$ & $146 \mathrm{rods} / \mathrm{h}$ & 4 & 4 \\
\hline & 3.13 Rod rework & $36 \mathrm{rods} / \mathrm{d}$ & $174 \mathrm{rods} / \mathrm{d}$ & 5 & 2,6 \\
\hline 4.0 & Fuel assembly fabrication & & & & \\
\hline & 4.1 Fuel rod storage & NA & 5 d production & $16,870 \mathrm{rods}$ & $17,000 \mathrm{rods}$ \\
\hline & $\begin{array}{ll}4.2 & \text { Fuel assembly fabrication } \\
4.3 & \text { Inspection }\end{array}$ & $\begin{array}{l}3 \text { assemblies/d } \\
6 \text { assemblies } / d\end{array}$ & $\begin{array}{l}13 \text { assemblies } / d \\
13 \text { assemblies/d }\end{array}$ & $\begin{array}{l}5 \\
3\end{array}$ & $\begin{array}{l}5 \\
3\end{array}$ \\
\hline & 4.4 Rework & 1 assembly/d & 0.07 assembly/d & $\mathrm{NR}^{d}$ & NR \\
\hline & Packaged fuel assembly storage & NA & $30 \mathrm{~d}$ production & 372 & 380 \\
\hline
\end{tabular}

aecommended units include consideration of spare capacity for operational reliability.

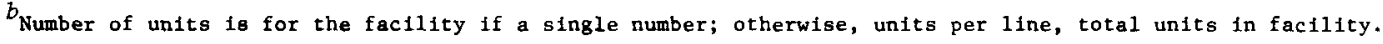
$c_{\text {NA: }}$ not applicable.

$d_{\mathrm{NR}}$ : not required. Use assembly equipment as available. 
Table 9.81. Research and Development Cost Estimates for Sphere-Pac Fabrication [NASAP Case 6.3.2, LMFBR U-Pu/Th, Spiked Recycle, GE Transmuter; Homogeneous Core Design]

\begin{tabular}{|c|c|c|c|c|}
\hline & R\&D Categories & Current Status $^{a}$ & $\begin{array}{l}\text { R\&D Cost Estimates } \\
\text { (Mil1ions of } \\
1978 \$)\end{array}$ & $\begin{array}{l}\text { Years to } \\
\text { Complete }\end{array}$ \\
\hline 1.0 & Program management & Not applicable & 10 & 10 \\
\hline 2.0 & Design studies & $N-\operatorname{cold}$ engineering & 25 & 10 \\
\hline 3.0 & Receiving and storage & $P-$ cold engineering & 4 & 5 \\
\hline 4.0 & Fuel production & $P$ - hot engineering & 25 & 6 \\
\hline 5.0 & Fuel rod fabrication & $\mathrm{P}-$ cold engineering & 50 & 8 \\
\hline 6.0 & Fuel element assembly & $\mathrm{N}-$ cold engineering & 27 & 8 \\
\hline 7.0 & Scrap recovery & $\mathrm{N}-\operatorname{cold}$ engineering & 4 & 5 \\
\hline 8.0 & Waste treatment & $b$ & $b$ & $b$ \\
\hline 9.0 & Plant control systems & $\mathrm{N}-$ cold prototype & 5 & 8 \\
\hline 10.0 & Maintenance & $N$ - cold prototype & 5 & 10 \\
\hline 11.0 & $\begin{array}{l}\text { Safeguards and account- } \\
\text { ability adaptation }\end{array}$ & $P-\operatorname{cold}$ engineering & 6 & 6 \\
\hline & Subtotal & & 161 & \\
\hline \multicolumn{5}{|c|}{ Special Facilities } \\
\hline \multicolumn{2}{|c|}{ Hot tests } & & 10 & \\
\hline \multicolumn{2}{|c|}{ Cold prototype } & & 25 & \\
\hline & Total & & $196^{d}$ & \\
\hline & Range & & $185-235$ & \\
\hline $\begin{array}{l}\mathrm{N}= \\
\operatorname{app} 1 \\
\operatorname{mi} 11\end{array}$ & $\begin{array}{l}{ }^{a} \text { Status stage with qualit } \\
\text { eeded. } \\
b_{\text {To be supplied by others }} \\
{ }^{c} \text { Assumes basic technology } \\
\text { cations testing, systems } \\
d_{\text {The estimate does not in }} \\
\text { on) or the capital costs }\end{array}$ & $\begin{array}{l}\text { ive modifiers; } C=\text { cor } \\
\text { s developed under oss } \\
\text { tegraton, and testing } \\
\text { ude costs for fuel qu } \\
\text { a pilot plant estima }\end{array}$ & $\begin{array}{l}\text { lete, } P=\text { in progre } \\
\text { stimate presented } \\
\text { ification tests } \\
\text { d at } \$ 170 \text { million. }\end{array}$ & $\begin{array}{l}s, \text { and } \\
\text { for } \\
\text { ut } \$ 20\end{array}$ \\
\hline
\end{tabular}


between this U-Pu fuel and the reference U-Pu fuel is the much higher concentration of plutonium. Development is under way in the United States on sphere forming, calcination, and sintering of ( $U, P u) O_{2}$ with $\mathrm{Pu} / \mathrm{U}$ ratios adequate for both the reference case and the fast reactor fuels.

While the functional fabrication processes are the same as those given for the reference gel-sphere-pac fabrication case, the design of the LMFBR fue1 elements is considerably different. These differences in design result in modifications to the details for accomplishing the various functional activities and modifications to the facility design details. In the subsequent paragraphs, each of the functional activities is discussed as it applies to this case.

A ge1-sphere-pac functional flow diagram is given in Fig. 3.1 of Sect. 3.1.1 of this report. The major functional areas apply to this case, and the two main functions unique to the gel-sphere-pac process are fuel production (2.0) and fuel rod fabrication (3.0). All the functional steps are briefly discussed here.

Receiving and Storage. This functional area is quite similar to the reference case. However, in addition to the spheres, the $\mathrm{ThO}_{2}$ pellets from the adjacent radial blanket assembly plant must be received, inspected, and stored.

Fuel Production. The fuel production processes for the spheres are essentially the same as those described for the reference case including calcination, sintering, and inspection of the coarse and medium sizes, which contain plutonium. No processing is planned for the $\mathrm{UO}_{2}$ fines because they are to be sintered at the reprocessing conversion step. However, because the $\mathrm{ThO}_{2}$ axial blanket pellets make up approximately $36 \%$ of the total heavy metal content in a core fuel assembly, the quantity of coarse and medium spheres processed is significantly less than in the reference case.

Fuel Rod Fabrication. While most of the fuel rod fabrication processes are similar to the reference case, additional steps are required to incorporate the axlal blanket material. The lower axial blanket section is loaded into the fuel rod cladding before the cladding is introduced into the cell. After the $(\mathrm{U}, \mathrm{Pu})_{2}$ core region is loaded by the sphere-pac process into each rod and inspected for density the upper axial blanket 
section will be loaded by equipment similar to that used for inserting plenum hardware. The actual plenum hardware insertion and end cap welding operations are essentially the same as those described for the reference case.

Fuel Assembly Operations. The fuel assembly design for this LMFBR case 6.3.2 is identical to that for the pellet fabrication option. Following fuel rod inspection each rod will be remotely wrapped with a wire. This special wire wrap will space the fuel rods in the assembly. Groups of these rods are assembled onto $\mathrm{T}$-bars of varying length. The $\mathrm{T}$-bar strip layers are assembled and fastened to the lower end box of the fuel assembly. The duct tube is installed and the finished assembly is inspected.

Product Control Processes. These are the same as the reference case (see Sect. 4.1.2).

Scrap and Waste Processing and Disposal. The scrap handling processes are similar to the reference case (see Sect.4.1.2) with the added feature that a11 axial blanket pellets that are unloaded from an unsatisfactory rod are inspected, and acceptable pellets are recycled within the remotely operated part of the facilities to form upper axial blankets.

\subsubsection{Preliminary Cost Estimate for Construction and Operation of a Commercial-Scale Plant}

The cost components that were estimated include capital costs for the facility and equipment, fuel assembly hardware costs, material and supply costs, and operating costs.

Facility capital cost estimates were based on an analysis of the functional flow diagram for the process to indicate space requirements for each functional area and for each support area. Equipment requirements were identified, and costs associated with the equipment were estimated. Fuel assembly hardware requirements were based on the reference fuel assembly design parameters identifled in Table 9.77. Estimates of the costs of the hardware items were obtained. Material and supply requirements were identified from the sphere-pac process description, and 
estimates of the costs of materials and supplies were obtained. Operating cost estimates included consideration of personnel, overhead, general and administrative expenses, and costs of utilities.

The facility was assumed to operate as a toll processing facility. That is, the operator fabricates customer-supplied fuel feed materials into finished fuel assemblies, and thus costs of plutonium and uranium were not included in the cost estimates. The hardware and material costs do include the costs associated with the production of the $\mathrm{ThO}_{2}$ pellets for the axial blanket.

Unit costs for fabrication of fuel assemblies are determined by an economic analysis of the basic capital, hardware and material, and operating cost estimates. Basically, the economic analysis provides for the owner of the fuel fabrication facility to recover all capital, operating, and finance charges plus a return on investment, if appropriate, over the life of the plant.

In order to provide a range of prices (i.e., costs to a customer), economic analyses were based on government financing, financing appropriate for a conventional-risk (typical) industry, and financing appropriate for a high-risk industry. ${ }^{2}$ The estimated costs, costs derived from the economic analysis, and the unit costs based on the three different financing methods are summarized in Tab1e 9.82. As may be observed from the table, the price for fabrication of ( $\mathrm{U}, \mathrm{Pu}) \mathrm{O}_{2}-\mathrm{ThO}_{2}$ fuel is expected to be in the range from $\$ 390$ to $\$ 760 / \mathrm{kg}$ depending on the financing technique that is employed. The recommended cost for comparison with other fuel cycles and methods of fabrication is the typical industry cost of $\$ 610 / \mathrm{kg}$ of heavy metal. As with all the cost estimates in this report, the prices are based on the mass of all heavy metal in the finished assembly. For this case, this includes the thorium in the axial blankets.

These cost estimates and prices are based on the assumed RO/CM facilities. If there is significant crossover of the bred ${ }^{233} \mathrm{U}$ to the $(\mathrm{U}, \mathrm{Pu}) \mathrm{O}_{2}$ core material during irradiation, the cost estimates and prices would increase and additional research and development would be needed to develop the remotely maintainable equipment. 
Table 9.82. Summary of Costs for Fabrication of Sphere-Pac PWR Fuel in a 2- $t \mathrm{HM} / \mathrm{d}$ Facility NASAP Case 6.3.2, LMFBR U-Pu/Th Spiked Recycle, (GE Transmuter) -

Homogeneous Core Design]

\begin{tabular}{|c|c|c|c|c|c|c|c|c|c|}
\hline \multirow[b]{2}{*}{$\begin{array}{c}\text { Economic } \\
\text { Set }^{a}\end{array}$} & \multicolumn{4}{|c|}{ Estimated Costs, \$ million } & \multicolumn{4}{|c|}{ Derived Costs, $\$$ million } & \multirow[b]{2}{*}{$\begin{array}{l}\text { Unit } \\
\text { Cost } b \\
(\$ / \mathrm{kg})\end{array}$} \\
\hline & Facility & Equipment & $\begin{array}{l}\text { Annual } \\
\text { Hardware } \\
\text { Plus } \\
\text { Materials }\end{array}$ & $\begin{array}{c}\text { Annual } \\
\text { Operating }\end{array}$ & $\begin{array}{l}\text { Owner's } \\
\text { Cost } \\
\text { During } \\
\text { Construction }\end{array}$ & $\begin{array}{c}\text { Charge on } \\
\text { Direct Capital } \\
\text { During } \\
\text { Construction }\end{array}$ & $\begin{array}{c}\text { Annual } \\
\text { Equipment } \\
\text { Replacement } \\
\text { Cost }\end{array}$ & $\begin{array}{c}\text { Annual } \\
\text { Payment to } \\
\text { Decommissioning } \\
\text { Fund }\end{array}$ & \\
\hline A & 280 & 270 & 68 & 27 & 39 & 140 & 14 & 1.3 & 390 \\
\hline B & 280 & 270 & 68 & 28 & 41 & 210 & 14 & 1.3 & 610 \\
\hline $\mathrm{c}$ & 280 & 270 & 68 & 29 & 42 & 210 & 14 & 1.3 & 760 \\
\hline
\end{tabular}

$a_{A}=$ Government financing; $B=$ Typical industrial financing; $C=$ High-risk industrial financing.

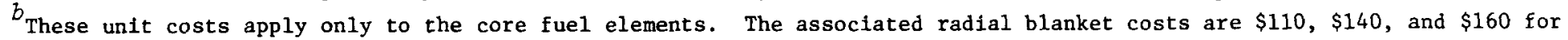
economic sets $A, B$, and $C$, respectively. 
9.18 NASAP CASE, 6.4 LMFBR Th-Pu/Th, SPIKED RECYCLE, GENERAL ELECTRIC TRANSMUTER [LMFBR ( $\mathrm{Pu}, \mathrm{Th}) \mathrm{O}_{2} \mathrm{WITH} \mathrm{ThO}_{2}$ BLANKETS]

\subsubsection{Fuel Cycle Description}

This reactor-fuel cycle combination is an LMFBR using $14.2 \%$ plutoniumthorium mixed oxide homogeneous core and thorium oxide blankets. The core and blanket are reprocessed separately. A1l the plutonium and part of the thorium recovered during reprocessing are recycled to core fabrication after being mixed with $\mathrm{Pu}-\mathrm{Th}$ makeup material from secure storage. The remaining thorium recovered during core reprocessing is combined with the thorium recovered during blanket reprocessing and sent to interim thorium storage for 10 years decay. The ${ }^{233} \mathrm{U}$ recovered during core reprocessing is mixed with depleted uranium and the $233_{\mathrm{U}}$ recovered during blanket reprocessing to produce a $12 \%$ fissile denatured product, which is sent to secure storage. Blanket assemblies are fabricated from new thorium.

In this fuel cycle analysis only the core fuel element fabrication has been assessed. The fissile components are a mixture of recycled plutonium and thorium from the reprocessing plant. This material will be very radioactive. Most of the gamma radiation will be from the $2.6-\mathrm{MeV}$ gamma emission of ${ }^{208} \mathrm{~T} 1$. The ${ }^{208} \mathrm{~T} 1$ is a daughter in the decay chain of ${ }^{232} \mathrm{U}$, which is one of the isotopes of uranium derived from thorium irradiation. Since ${ }^{229} \mathrm{Th}$ is a precursor in this decay chain it is separated with the balance of the thorium during reprocessing. During subsequent decay ${ }^{228} \mathrm{Th}$ (its half-life is 1.91 years) provides the source of the 208 1 . This high-level gamma activity alone will require that all fissile fuel processing, fuel rod fabrication, and fuel element assembly for this case be conducted in a remotely operated and remotely maintained facility. However, the extended burnup on recycle will also cause the plutonium component to be very radioactive, as isotopes other than ${ }^{239} \mathrm{Pu}$ build up in the material.

The core assemblies also include $\mathrm{ThO}_{2}$ pellets as axial blanket material above and below the fissile portion. Since the radial blanket assemblies are assumed to be fabricated in an adjacent contact-operated and contact-maintained facility and are loaded only with pelletized $\mathrm{ThO}_{2}$, we assume that axial blanket pellets will be supplied from this facility. 


\subsubsection{Applicability to Current Fuel Element Design}

The fuel element design chosen for this case is given in Table 9.83.

The key considerations for sphere-pac applicability are the cladding inside diameter measurements and the required fuel smear density. The cladding of ID of $7210 \mu \mathrm{m}$ in the reference design is suitable for the sphere-pac process. Although the specified smear density of $90 \%$ of theoretical is above that currently achieved with experimental blended (three particle size) sphere-pac beds, we have assumed that the process is applicable through a slight lowering of this design requirement.

\subsubsection{Definition of Plant Production Requirements and Design Capacity}

For the LMFBR $(\mathrm{Pu}, \mathrm{Th})_{2}$ with $\mathrm{ThO}_{2}$ axial blanket fuel cycle, the plant design assumptions are listed below.

1. The fuel design is the General Electric Company Advanced Reactor Systems Department homogeneous transmuter reactor fuel design.

2. The plant production capacity is $480 \mathrm{t} \mathrm{HM} /$ year with the capability for simultaneous production of three enrichments.

3. The plant factor is 240 effective full-production days per year.

4. Plant design capacity:

$$
\begin{array}{ll}
\text { Overall } & 730 \mathrm{t} \mathrm{HM} / \text { year } \\
& \text { about } 12 \mathrm{fuel} \text { assemblies/d } \\
\text { Each line of three } & 243 \mathrm{t} \mathrm{HM} / \text { year } \\
& 0.67 \mathrm{t} \mathrm{HM} / \mathrm{d} \\
& 1032 \mathrm{fue} 1 \mathrm{rods} / \mathrm{d} \\
& 3.8 \mathrm{fuel} \text { assemblies/d }
\end{array}
$$

5. Process design capacities are based on the line design capacities and the scrap and sample losses defined in Sect. 9.18.4.

6. The facilities are designed to discharge no liquid waste other than treated sanitary sewage.

7. All process buildings and critical auxiliary support are designed and constructed in accordance with current United States Nuclear Regulatory Commission licensing requirements. Shielding is provided to limit dose rates to operating and maintenance personnel to $0.25 \mathrm{millirem} / \mathrm{h}$. 
Table 9.83. Sumnary of General Electric Transmuter LMFBR Fuel Assembly Parameters [NASAP Case 6.4, LMFBR $(\mathrm{Pu}, \mathrm{Th}) \mathrm{O}_{2}$ with $\mathrm{ThO}_{2}$ Blankets]

\section{Reactor Characteristics}

Reactor power
Fuel assemblies
Inner blanket assemblies
Radial blanket assemblies
Control. assemblies
Removable shield assemblies
Fissile enrichment, \%

Fissile enrichment, \%

Component Characteristics

Fuel cladding

End plugs

Top

Bottom

Reflector rods

Plenum springs

Spacers

Wire wrap

Attachment rails

Locking pins

Shield and inlet assemblies

Duct and upper handling

socket

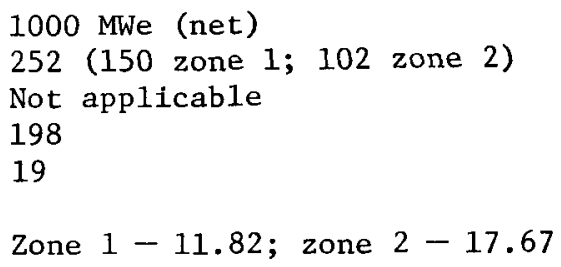

1

1

Fuel Rod Characteristics

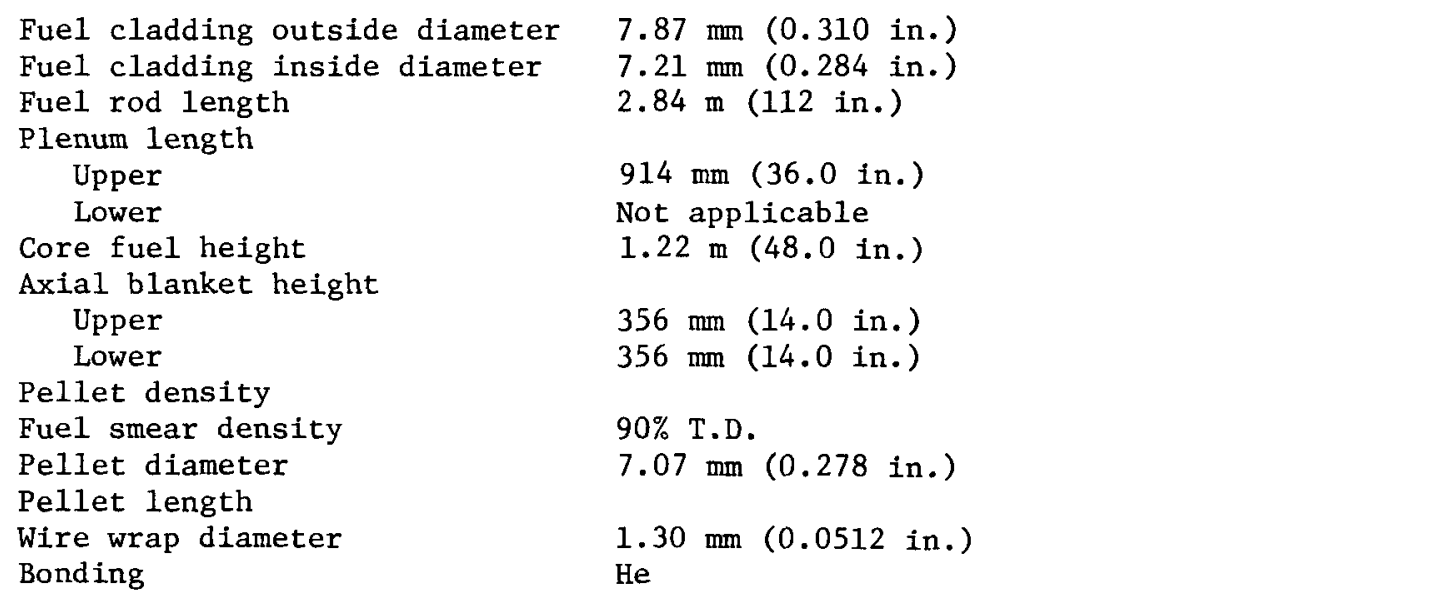

Fuel Assembly Characteristics

Array
Fuel assembly length
Duct outside flat-to-flat
Duct wall thickness
Mass of structural components
Heavy metal content
$\quad$ Core
$\quad$ Axial blanket

\section{Hexagona1}

$161.1 \mathrm{~mm}$ (6.33 in.)

$3.30 \mathrm{~mm}(0.130$ in. $)$

$109.18 \mathrm{~kg}$

$65.85 \mathrm{~kg}$ 
In addition, we assumed that production from each fuel rod line is campaigned to provide a full reload segment for a single 1000-MWe (net) LMFBR. Thus, the total heavy metal output for a given campaign is $22.1 \mathrm{t}$, and each campaign requires about 33 effective full-production days (50 calendar days). The total facility can support approximately 27 such reactors.

\subsubsection{Estimates of Surge Storage Requirements, Scrap Production Rates, and Processing Rates for Functional Steps}

Given the plant design assumptions defined in Sect.9.18.3, further commercial plant characteristics were derived.

To achieve the annual production rates, an analysis of the plant surge storage requirements and normal inventory was made, and the results of this analysis are given in Table 9.84 .

Based on current technology and assuming reasonable extrapolations for commercial-scale developments, a preliminary estimate was made of the daily mass flows of heavy metal through the fabrication plant and the average production rate of heavy metal scrap materials from the various functional activities. These are presented in Table 9.85.

Given the above information, a preliminary evaluation of the processing rate for each functional step within the main fuel fabrication processes was made. The results of this analysis are summarized in Table 9.86 .

\subsubsection{Analysis of Functional Technology Status, Research and Development Requirements, Cost, and Schedule}

The technology status of this system is quite similar to that of the reference case discussed in Sect. 8. The current status and research and development needs are summarized in Table 9.87. The primary difference between this $(\mathrm{Pu}, \mathrm{Th}) \mathrm{O}_{2}$ fuel and the $(\mathrm{U}, \mathrm{Pu}) \mathrm{O}_{2}$ fuel is the level of current development effort on sphere forming, calcination, and sintering. Currently $(\mathrm{U}, \mathrm{Pu}) \mathrm{O}_{2}$ is under investigation in the United States, and the $(\mathrm{Pu}, \mathrm{Th})_{2}$ system would need to be initiated at the $\mathrm{Pu} / \mathrm{Th}$ ratio required for this fuel. 
Table 9.84. Sphere-Pac Fabrication Plant Surge Storage Requirements and Normal Inventory (NASAP Case 6.4, LMFBR Th-Pu/Th Spiked Recycle, GE Transmuter)

\begin{tabular}{|c|c|c|c|c|c|c|}
\hline \multirow{2}{*}{ Process step } & \multirow{2}{*}{ Material } & \multicolumn{2}{|c|}{$\begin{array}{l}\text { Storage } \\
\text { Interval, } \mathrm{d}\end{array}$} & \multicolumn{3}{|c|}{ Norma1 Inventory, $\mathrm{kg} \mathrm{HM}$} \\
\hline & & Normal & Maximum & $(\mathrm{Pu}, \mathrm{Th}) \mathrm{O}_{2}$ & $\mathrm{ThO}_{2}$ Fines & $\mathrm{ThO}_{2}$ Pellets \\
\hline Feed storage & $\begin{array}{l}\text { Dried spheres } \\
\text { Sintered spheres } \\
\text { Sintered pellets }\end{array}$ & $\begin{array}{l}30 \\
30 \\
30\end{array}$ & $\begin{array}{l}60 \\
60 \\
60\end{array}$ & 31,000 & 8,200 & 10,300 \\
\hline Interim storage & $\begin{array}{l}\text { Dried spheres } \\
\text { Sintered spheres } \\
\text { Sintered pellets }\end{array}$ & $\begin{array}{l}1 \\
1 \\
1\end{array}$ & $\begin{array}{l}2 \\
2 \\
2\end{array}$ & 1,040 & 270 & 340 \\
\hline Furnace & $\begin{array}{l}\text { Dried to sintered } \\
\text { spheres }\end{array}$ & 1.2 & 2.4 & 1,240 & & \\
\hline Post furnace & Sintered spheres & 0.5 & 1 & 1,520 & & \\
\hline Interim storage & Sintered spheres & 0.36 & 0.72 & 370 & & \\
\hline Main storage & $\begin{array}{l}\text { Sintered spheres } \\
\text { Sintered spheres } \\
\text { Sintered pellets }\end{array}$ & $\begin{array}{l}1.2 \\
1.5 \\
1.5\end{array}$ & $\begin{array}{l}2.4 \\
2.9 \\
2.9\end{array}$ & 1,310 & 410 & 590 \\
\hline $\begin{array}{l}\text { Loading, inspection, } \\
\text { welding }\end{array}$ & $\begin{array}{l}\text { Sintered spheres } \\
\text { and pellets }\end{array}$ & 0.12 & 0.24 & 120 & 30 & 45 \\
\hline $\begin{array}{l}\text { Loaded, not inspected } \\
\text { rods }\end{array}$ & $\begin{array}{l}\text { Sintered spheres } \\
\text { in rods }\end{array}$ & 5 & 5 & 5,200 & 1,290 & 3,900 \\
\hline Rework and scrap & $\begin{array}{l}\text { Sintered spheres } \\
\text { and pellets }\end{array}$ & 2 & 5 & 260 & 50 & 100 \\
\hline Completed fuel rods & $\begin{array}{l}\text { Sintered spheres } \\
\text { and pellets } \\
\text { in rods }\end{array}$ & 5 & 5 & 5,000 & 1,250 & 3,780 \\
\hline Assembly & $\begin{array}{l}\text { Rods in completed } \\
\text { assemblies }\end{array}$ & 15 & 30 & 15,000 & 3,740 & 11,300 \\
\hline
\end{tabular}


Table 9.85. Heavy Metal Mass Flows and Average Scrap Production for a Sphere-Pac Fuel Fabrication Plant (NASAP Case 6.4, LMFBR Th-Pu/Th, Spiked Recycle, GE Transmuter)

\begin{tabular}{|c|c|c|c|c|c|c|c|c|c|}
\hline \multirow{3}{*}{ Processing Step } & \multicolumn{9}{|c|}{ Mass Flow, $\mathrm{kg} \mathrm{HM} / \mathrm{d}$} \\
\hline & \multicolumn{3}{|c|}{ Darly Throughput } & \multicolumn{3}{|c|}{ Clean Scrap $b$} & \multicolumn{3}{|c|}{ Reject Scrap $^{C}$} \\
\hline & $(\mathrm{Pu}, \mathrm{Th}) \mathrm{O}_{2}^{a}$ & $\begin{array}{l}\mathrm{ThO}_{2} \\
\text { Fines }\end{array}$ & $\begin{array}{l}\text { Axial Blanket } \\
\text { ThO }_{2} \text { Pellets }\end{array}$ & $(\mathrm{Pu}, \mathrm{Th}) \mathrm{O}_{2}{ }^{a}$ & $\begin{array}{l}\mathrm{ThO}_{2} \\
\text { Fines }\end{array}$ & $\begin{array}{l}\text { Axial Blanket } \\
\mathrm{ThO}_{2} \text { Pellets }\end{array}$ & $(\mathrm{Pu}, \mathrm{Th}) \mathrm{O}_{2}{ }^{a}$ & $\begin{array}{l}\mathrm{ThO}_{2} \\
\text { Fines }\end{array}$ & $\begin{array}{l}\text { Axıal Blanket } \\
\mathrm{ThO}_{2} \text { Pellets }\end{array}$ \\
\hline Recelving and storage & 1036.8 & $273.1^{d}$ & 755.5 & & & & & & \\
\hline Sampling and batch loading & 1035.8 & & & & & & 1.0 & & \\
\hline Werghing and sampling & & 272.8 & $754.7^{e}$ & & & & & 0.3 & 0.8 \\
\hline Calcining and sintering & 1035.3 & & & & & & 0.5 & & \\
\hline Sphere upgrading & $1093.5^{f}$ & & & & & & 31.1 & & \\
\hline Sphere sampling & 1091.3 & & & & & & 2.2 & & \\
\hline Interim storage & 1091.3 & 272.8 & 411.4 & & & & & & \\
\hline Fuel rod loading & 1091.3 & 272.8 & 411.4 & & & & & & \\
\hline Fuel rod scanning & 1036.8 & 259.2 & $781.6^{9}$ & 52.4 & 13.1 & 19.7 & 2.2 & 0.5 & 0.8 \\
\hline Top component insertion & 1034.5 & 258.6 & 779.9 & 2.1 & 0.5 & 1.6 & 0.2 & 0.1 & 0.2 \\
\hline Rod welding and $x$ ray & 1034.5 & 258.6 & 779.9 & $h$ & h & $h$ & $n$ & $h$ & $h$ \\
\hline Leak detection & 1034.5 & 258.6 & 779.9 & $h$ & $h$ & $h$ & $h$ & $h$ & $n$ \\
\hline Rod assay & 1013.8 & 253.5 & 764.3 & 19.7 & 4.9 & 14.8 & 1.0 & 0.3 & 0.8 \\
\hline Final rod inspection & 1003.3 & 250.8 & 756.4 & 10.1 & 2.5 & 7.6 & 0.4 & 0.1 & 0.3 \\
\hline Assembly inspection & 998.1 & 249.5 & 752.4 & 5.0 & 1.3 & 3.8 & $\underline{0.2}$ & 0.1 & $\underline{0.2}$ \\
\hline Total & & 2000 & & 89.3 & 22.3 & 47.5 & 38.8 & 1.4 & 3.1 \\
\hline
\end{tabular}

${ }^{a} 11.82$ and $17.67 \%$ average fissile plutonium contents in Zones 1 and 2 , respectively.

${ }^{b}$ Internally recycled.

${ }^{c}$ Collected, assayed, and externally recycled to reprocessing plant.

Includes $22.3 \mathrm{~kg}$ of recycled clean scrap.

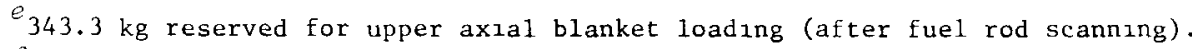

Includes $89.3 \mathrm{~kg}$ of recycled clean scrap.

$g$ Includes $47.5 \mathrm{~kg}$ of recycled clean scrap plus $343.3 \mathrm{~kg}$ of fresh material for upper axial blanket loading.

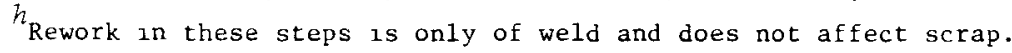


Table 9.86. Equipment Riquirements for Functional Areas (NASAP Case 6.4 LMFBR Th-Pu/Th, Splked Recycle, GE Transmuter)

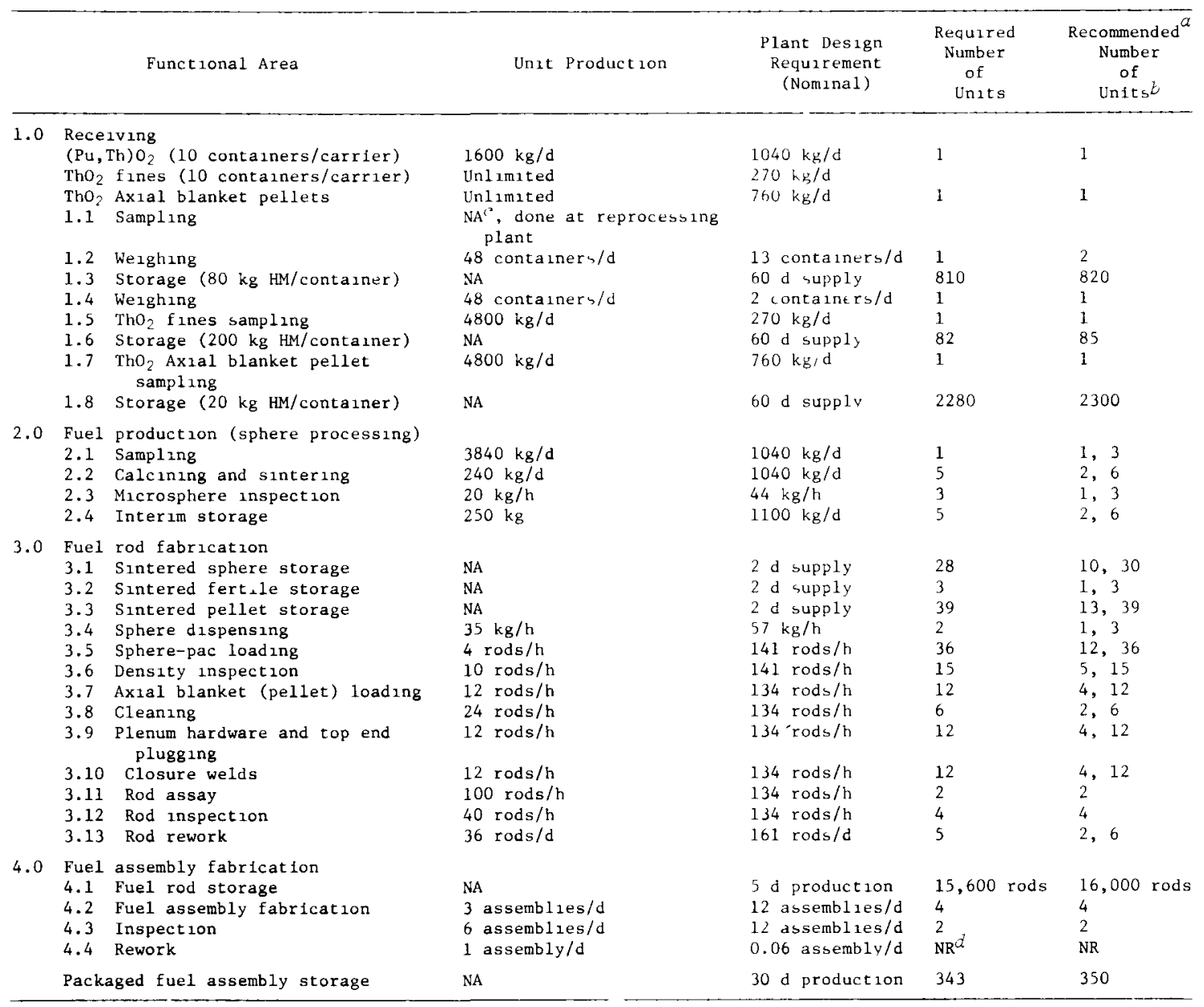

Recommended units include consideration of spare capacity for operat ional reliability.

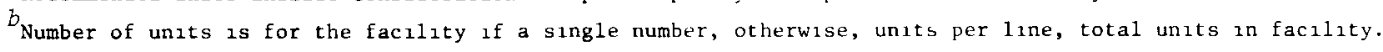

NA: not applicable.

$d_{\mathrm{NR}}$ : not required. Use assembly equipment as avaslable. 
Table 9.87. Research and Development Cost Estimates for Sphere-Pac Fabrication [NASAP Case 6.4 LMFBR Th-Pu/Th, Spiked Recycle, GE Transmuter]

\begin{tabular}{|c|c|c|c|c|}
\hline & R\&D Categories & Current Status ${ }^{a}$ & $\begin{array}{l}\text { R\&D Cost Estimates } \\
\text { (Millions of } \\
1978 \$ \text { ) }\end{array}$ & $\begin{array}{l}\text { Years to } \\
\text { Complete }\end{array}$ \\
\hline 1.0 & Program management & Not applicable & 10 & 10 \\
\hline 2.0 & Design studies & $\mathrm{N}-$ cold engineering & 25 & 10 \\
\hline 3.0 & Receiving and storage & $\mathrm{P}-$ cold engineering & 4 & 5 \\
\hline 4.0 & Fuel production & $P$ - hot laboratory & 30 & 8 \\
\hline 5.0 & Fuel rod fabrication & $P-$ cold engineering & 55 & 8 \\
\hline 6.0 & Fuel element assembly & $N-$ cold engineering & 32 & 8 \\
\hline 7.0 & Scrap recovery & $\mathrm{N}$ - hot laboratory & 7 & 6 \\
\hline 8.0 & Waste treatment & $b$ & $b$ & $b$ \\
\hline 9.0 & Plant control systems & $\mathrm{N}-\operatorname{cold}$ prototype & 5 & 8 \\
\hline 10.0 & Maintenance & $\mathrm{N}-$ cold prototype & 10 & 10 \\
\hline 11.0 & $\begin{array}{l}\text { Safeguards and account- } \\
\text { ability adaptation }\end{array}$ & $P-$ cold engineering & 6 & 6 \\
\hline & Subtotal & & 184 & \\
\hline \multicolumn{5}{|c|}{ Special Facilities } \\
\hline \multicolumn{2}{|c|}{ Hot tests } & & 10 & \\
\hline \multicolumn{2}{|c|}{ Cold prototype } & & 25 & \\
\hline & Total & & $219^{d}$ & \\
\hline & Range & & $210-265$ & \\
\hline $\begin{array}{l}\mathrm{N}=\mathrm{n} \\
\mathrm{app} 1 \mathrm{i} \\
\mathrm{mi} 11 \mathrm{i}\end{array}$ & $\begin{array}{l}{ }^{a} \text { Status stage with qualit } \\
\text { eeded. } \\
b_{\text {To be supplied by others }} \\
{ }^{c} \text { Assumes basic technology } \\
\text { cations testing, systems } \\
d_{\text {The estimate does not in }} \\
\text { on) or the capital costs }\end{array}$ & $\begin{array}{l}\text { ive modifiers; } \mathrm{C}=\mathrm{co} \\
\text { s developed under oss } \\
\text { tegraton, and testing } \\
\text { ude costs for fuel qua } \\
\text { a pilot plant estima }\end{array}$ & $\begin{array}{l}\text { lete, } P=\text { in progr } \\
\text { stimate presented } \\
\text { ification tests }(a b \\
d \text { at } \$ 240 \text { million. }\end{array}$ & $\begin{array}{l}s \text {, and } \\
\text { for } \\
\text { ut } \$ 20\end{array}$ \\
\hline
\end{tabular}


While the general fabrication process descriptions are the same as those given for the reference gel-sphere-pac fuel fabrication, the design of the LMFBR fuel assembly is considerably different. These differences in design result in modifications to the details for accomplishing the various functional activities and to the facility design details. These differences are discussed here as they apply specifically to case 6.4 .

A gel-sphere-pac generic functional flow diagram is given in Fig. 3.1 of Sect. 3.1.1. The main functions unique to the ge1-sphere-pac process are fuel production (2.0) and fuel rod fabrication (3.0). Brief process descriptions of the various functional steps are given below.

Receiving and Storage. This functional area is quite similar to the reference case with the following exception. Since the mass flow data require recycle thorium for the fissile portion of the fuel loading, the fertile fines spheres are also generated in the conversion process of the reprocessing plant and must be received and stored in the shielded storage area.

Fuel Production. The fuel production processes are essentially the same as those described for the reference case including calcination, sintering, and inspection. However, since the axial blanket material $\left(\mathrm{ThO}_{2}\right.$ pellets) makes up approximately $38 \%$ of the total heavy metal content in a core fuel assembly, the quantity of material processed is significantly less. The $\mathrm{ThO}_{2}$ blanket pellets are manufactured in an adjacent contact-operated and contact-maintained facility.

Fuel Rod Fabrication. While most of the fuel rod fabrication processes are similar, additional steps are required to incorporate the axial blanket material. The lower axial blanket section is loaded into the fuel cladding before the cladding is introduced into the cell. After the $(\mathrm{Pu}, \mathrm{Th}) \mathrm{O}_{2}$ sphere-pac core region is loaded into each rod and inspected for density the upper axial blanket section will be loaded. The remainder of the fuel rod fabrication steps are the same as for the reference case.

Fuel Assembly Operations. The fuel assembly design for this LMFBR case 6.4 is identical to that for the pellet fabrication option. Following fuel rod inspection each rod will be remotely wrapped with a wire. This special wire wrap will space the fuel rods in the assembly. Groups of these rods are assembled onto T-bars of varying length. The 
T-bar strip layers are assembled and fastened to the lower end box of the fuel assembly. The duct tube is installed and the finished assembly is inspected.

Product Control Processes. These are the same as the reference case (see Sect. 4.1.2).

Scrap and Waste Processing and Disposal. The scrap handling processes are similar to the reference case (see Sect.4.1.2) with the added feature that all axial blanket pellets that are unloaded from an unsatisfactory rod are inspected, and acceptable pellets are recycled within the remotely operated part of the facilities to form upper axial blankets.

\subsubsection{Preliminary Cost Estimate for Construction and Operation of a Commercial-Scale Plant}

The cost components that were estimated include capital costs for the facility and equipment, fuel assembly hardware costs, material and supply costs, and operating costs.

Because of the uniqueness of this cycle in which a portion of the thorium is recycled with the plutonium, additional shielded space is required for the production of thoria fine spheres. This is shown in Fig. 9.1. This same figure shows modifications in the other portions of the shielded process area required to fabricate the LMFBR fuel rods and assemblies. The components for each fuel rod fabrication line are shown in Fig. 9.2.

Facility capital cost estimates were based on an analysis of the functional flow diagram for the process to indicate space requirements for each functional area and for each support area. Equipment requirements were identified, and costs associated with the equipment were estimated. Fuel assembly hardware requirements were based on the reference fuel assembly design parameters identified in Table 9.83. Estimates of the costs of the hardware items were obtained. Material and supply requirements were identified from the sphere-pac process description, and estimates of the costs of materials and supplies were obtained. Operating cost estimates included consideration of personnel, overhead, general and administrative expenses, and costs of utilities. 


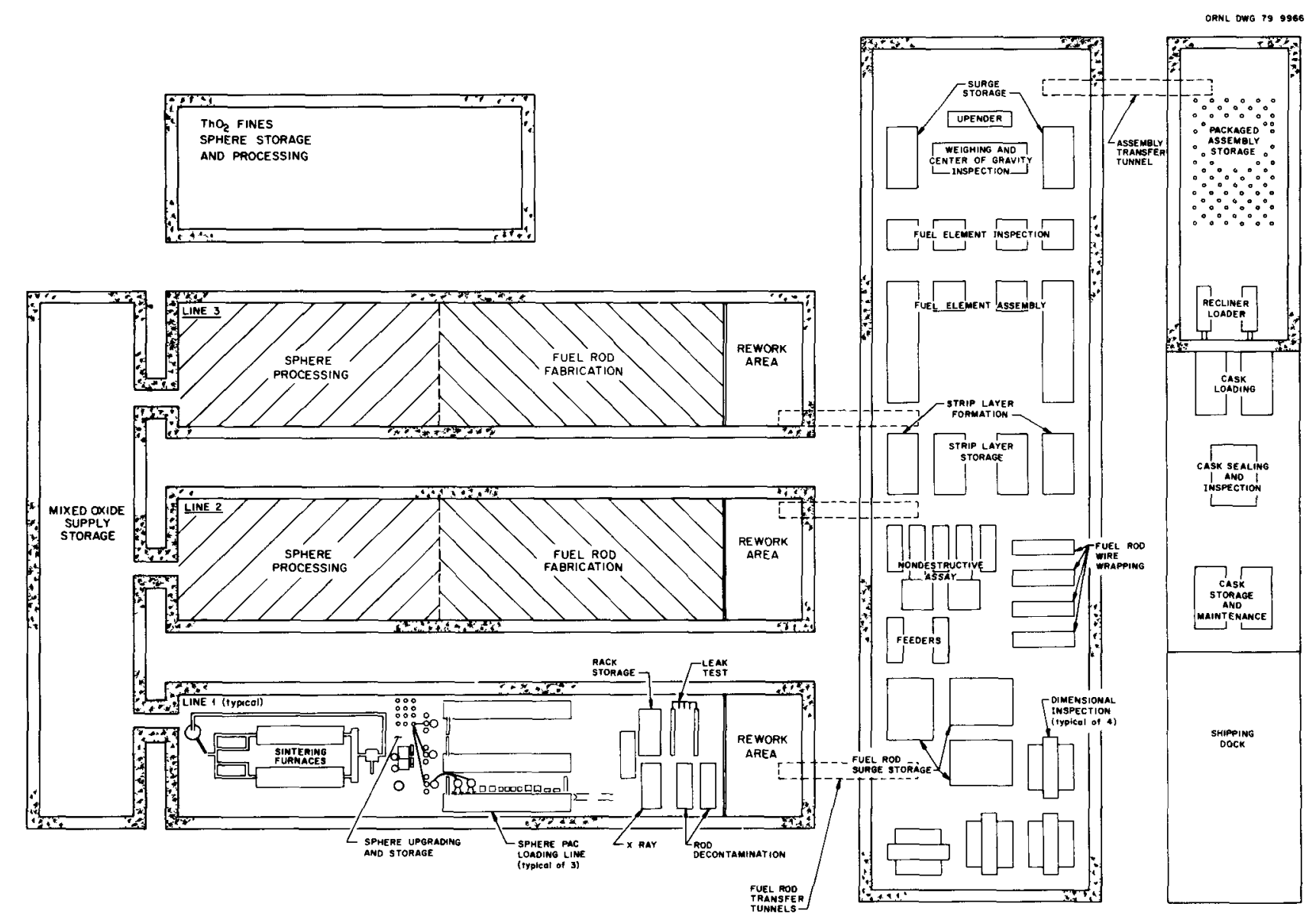

Fig. 9.1. Preconceptual Layout of Processing Areas for Sphere-Pac Fabrication of Spiked (Pu,Th) $\mathrm{O}_{2}$ LMFBR Fuel Assemblies. 
ORNL-DWG 79-9965R

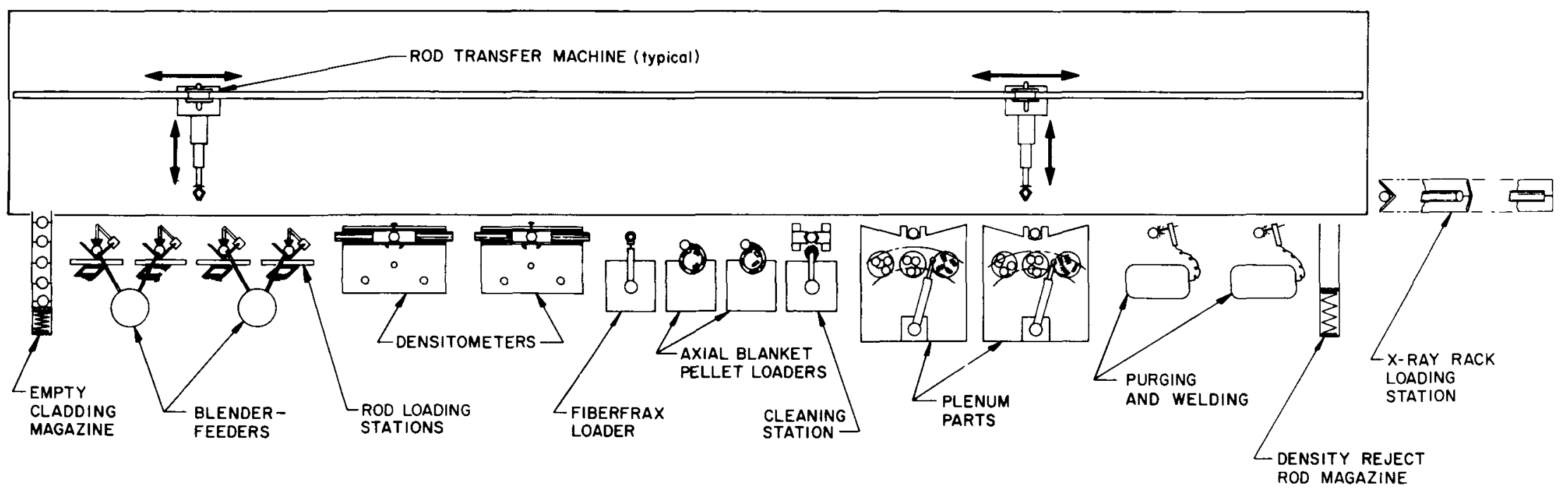

Fig. 9.2. Conceptual Sphere-Pac Rod Loading Line for LMFBR Fuels. 
The facility was assumed to operate as a toll processing facility. That is, the operator fabricates customer-supplied fuel feed materials into finished fuel assemblies, and thus costs of plutonium and thorium were not included in the cost estimates. The hardware and material costs do include the costs associated with the production of the fresh $\mathrm{ThO}_{2}$ pellets for the axial blanket.

Unit costs for fabrication of fuel assemblies are determined by an economic analysis of the basic capital, hardware and material, and operating cost estimates. Basically, the economic analysis provides for the owner of the fuel fabrication facility to recover all capital, operating, and finance charges plus a return on investment, if appropriate, over the life of the plant.

In order to provide a range of prices (i.e., costs to a customer), economic analyses were based on government financing, financing appropriate for a conventional-risk (typical) industry, and financing appropriate for a high-risk industry. 2 The estimated costs, costs derived from the economic analysis, and the unit costs based on the three different financing methods are summarized in Table 9.88. As may be observed from the table, the price for fabrication of $(\mathrm{Pu}, \mathrm{Th}) \mathrm{O}_{2}$ fuel is expected to be in the range from $\$ 470$ to $\$ 1000 / \mathrm{kg}$ depending on the financing technique that is employed. The recommended cost for comparison with other fuel cycles and methods of fabrication is the typical industry cost of $\$ 780 / \mathrm{kg}$ of heavy metal. As with all the cost estimates in this report, the prices are based on the mass of all heavy metal in the fintshed assembly. For this case, this includes the thorium in the axial blankets. 
Table 9.88. Sumary of Costs for Fabrication of Sphere-Pac PWR Fuel in a 2-t HM/d Facility (NASAP Case 6.4, LMFBR Th-Pu/Th, Spiked Recycle, GE Transmuter)

\begin{tabular}{|c|c|c|c|c|c|c|c|c|c|}
\hline \multirow[b]{2}{*}{$\begin{array}{l}\text { Economic } \\
\text { Set }\end{array}$} & \multicolumn{4}{|c|}{ Estimated Costs, $\$$ million } & \multicolumn{4}{|c|}{ Derived Costs, \$ million } & \multirow[b]{2}{*}{$\begin{array}{l}\text { Unit } \\
\text { Cost } b \\
(\$ / \mathrm{kg})\end{array}$} \\
\hline & Facility & Equipment & $\begin{array}{c}\text { Annual } \\
\text { Hardware } \\
\text { Plus } \\
\text { Materials }\end{array}$ & $\begin{array}{c}\text { Annual } \\
\text { Operating }\end{array}$ & $\begin{array}{l}\text { Owner's } \\
\text { Cost } \\
\text { During } \\
\text { Construction }\end{array}$ & $\begin{array}{c}\text { Charge on } \\
\text { Direct Capital } \\
\text { During } \\
\text { Construction }\end{array}$ & $\begin{array}{c}\text { Annual } \\
\text { Equipment } \\
\text { Replacement } \\
\text { Cost }\end{array}$ & $\begin{array}{c}\text { Annual } \\
\text { Payment to } \\
\text { Decommissioning } \\
\text { Fund }\end{array}$ & \\
\hline A & 454 & 354 & 64 & 29 & 42 & 210 & 18 & 1.3 & 470 \\
\hline B & 454 & 354 & 64 & 30 & 43 & 309 & 18 & 1.4 & 780 \\
\hline $\mathrm{C}$ & 454 & 354 & 64 & 31 & 44 & 309 & 18 & 1.4 & 1000 \\
\hline
\end{tabular}

$a_{\mathrm{A}}=$ Government financing; $\mathrm{B}=$ Typical industrial financing; $\mathrm{c}=$ High-risk industrial financing.

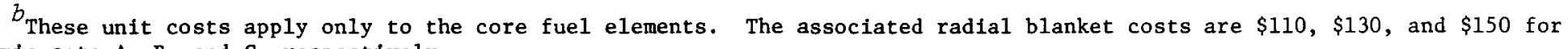
economic sets $A, B$, and $C$, respectively. 


\subsection{NASAP CASE 6.5, LMFBR DU(3)/Th RECYCLE}

\subsubsection{Fuel Cycle Description}

This reactor-fuel cycle combination is an LMFBR using a $10.1 \%$ fissile recycle $233 \mathrm{U}$ oxide homogeneous core and a thorium oxide blanket. The core and blanket are reprocessed separately. The denatured $233_{U}$ recovered during core reprocessing is mixed with the undiluted $233 \mathrm{U}$ from the blanket reprocessing and makeup denatured $233_{U}$ to provide the feed for fabrication. The plutonium recovered during core reprocessing is placed in secure storage. Thorium recovered during blanket reprocessing is placed in interim storage for ten years. Blanket assemblies are fabricated from new or decayed thorium.

In this fuel cycle analysis, only fabrication of the core assemblies is considered. The blending of highly enriched uranium from the blanket with any required makeup uranium is assumed to be done at the reprocessing plant before the conversion process. Thus, the reprocessing plant will supply the coarse and medium sizes of spheres with the appropriate quantity of fissile uranium in the as-dried condition. The $\mathrm{UO}_{2}$ fines particles are supplied in the fully sintered condition either from a contact-operated and contact-maintained ( $\mathrm{CO} / \mathrm{CM})$ line at the reprocessing plant or in an adjunct facility to this plant. Since they contain only depleted or natural uranium and represent only about $15 \%$ of the total heavy metal in the finished assemblies, the required construction and operating costs will not significantly affect either the reprocessing or refabrication cost estimates. The pellets for the axial blanket regions in these assemb1ies will be supplied from an adjacent CO/CM facility where the radial blanket assemblies are fabricated.

The high levels of radioactivity from the $232 \mathrm{U}$ decay products associated with the $233_{U}$ will require a remotely operated and remotely maintained (RO/RM) facility.

\subsubsection{Applicability to Current Fuel Element Design}

The core fuel element design chosen for this cycle is given in Table 9.89. 
Table 9.89. Summary of General Electric Denatured LMFBR Fuel Assembly Parameters

[NASAP Case 6.5 - DU(3)/Th Recycle]

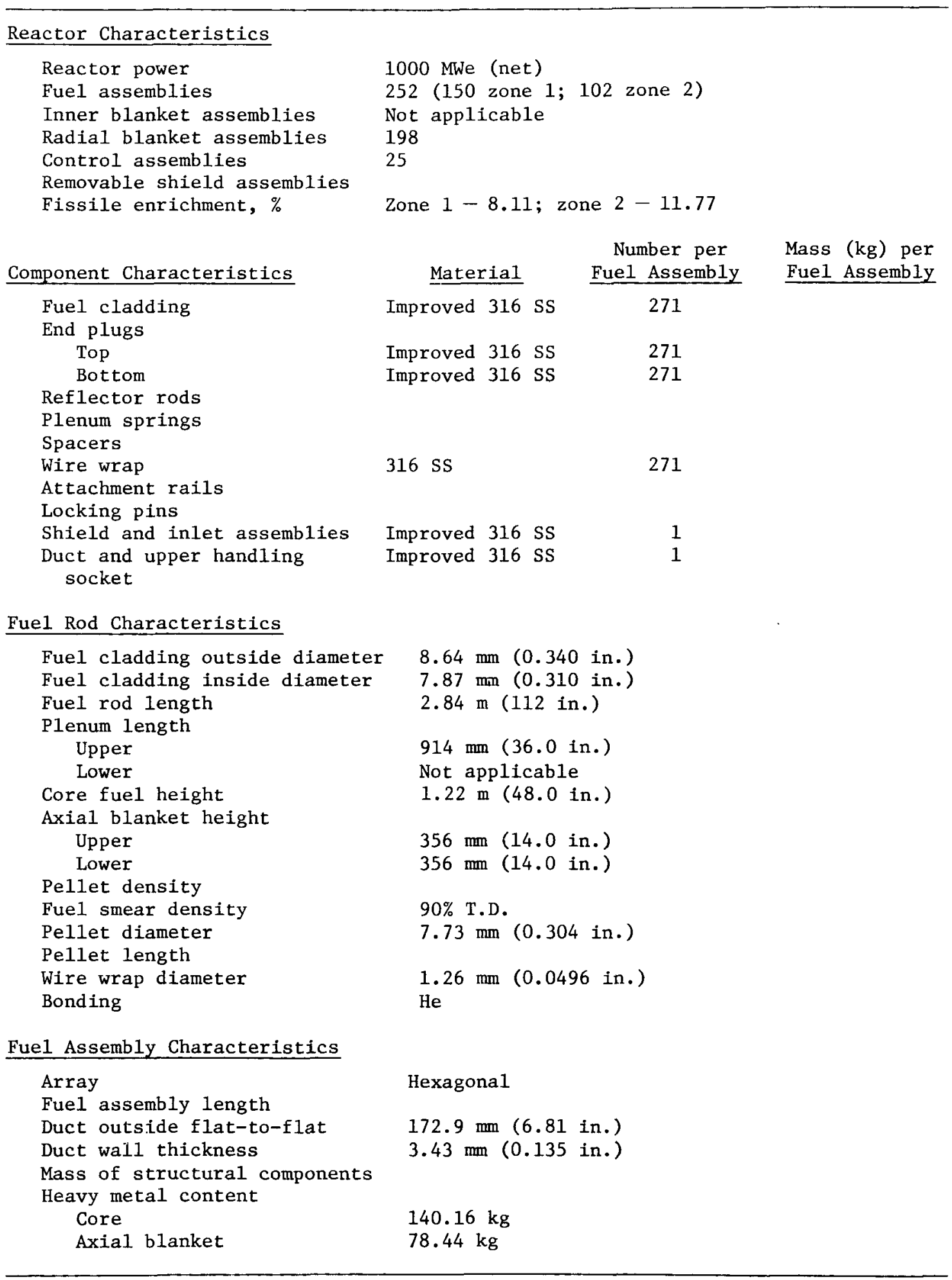


The key considerations for sphere-pac applicability are the cladding inside diameter measurements and the required fuel smear density. The cladding ID of $7870 \mu \mathrm{m}$ in the reference design is suitable for the spherepac process. Although the specified smear density of $90 \%$ of theoretical is above that currently achieved with experimental blended (three particle size) sphere-pac beds, we have assumed the process is applicable through a slight lowering of this design requirement.

\subsubsection{Definition of Plant Production Requirements and Design Capacity}

For this LMFBR $\mathrm{UO}_{2}-\mathrm{ThO}_{2}$ fuelcycle, the plant design assumptions are listed below. The heavy metal through-put for this plant and all cases involving axial blanket fuel is based on the total heavy metal in the finished fuel assembly, in both core and blanket.

1. The fuel design is the General Electric Company Advanced Reactor Systems Department homogeneous reactor denatured fue1 design.

2. The plant production capacity is $480 \mathrm{tHM} /$ year with the capability for simultaneous production of three enrichments.

3. The plant factor is 240 effective full-production days per year.

4. Plant design capacity:

Overa11

Each line of three
$730 \mathrm{t} \mathrm{HM} /$ year

about 9 fuel assemblies/d

$243 \mathrm{t} \mathrm{HM} /$ year

$0.67 \mathrm{t} \mathrm{HM} / \mathrm{d}$

826 fuel rods/d

3.0 fuel assemblies/d

5. Process design capacities are based on the line design capacities and the scrap and sample losses defined in Sect.9.19.4.

6. The facilities are designed to discharge no liquid waste other than treated sanitary sewage.

7. All process buildings and critical auxiliary support are designed and constructed in accordance with current United States Nuclear Regulatory Commission licensing requirements. Shielding is provided to limit dose rates to operating and maintenance personnel to $0.25 \mathrm{millirem} / \mathrm{h}$. 
In addition, we assumed that production from each fuel rod line is campaigned to provide a full reload segment for a single 1000-MWe LMFBR. Thus, the total heavy metal output for a given campaign is $27.5 \mathrm{t}$, and each campaign requires 41.3 effective ful1-production days ( 63 calendar days). The total facility, with an adjacent radial blanket assembly plant, can support approximately 26 such reactors.

\subsubsection{Estimates of Surge Storage Requirements, Scrap Production Rates, and Processing Rates for Functional Steps}

Given the plant design assumptions defined in Sect. 9.19.3, further commercial plant characteristics were derived.

To achieve the annual production rates, an analysis of the plant surge storage requirements and normal inventory was made, and the results of this analysis are given in Table 9.90.

Based on current technology and assuming reasonable extrapolations for commercial-scale developments, a preliminary estimate was made of the daily mass flows of heavy metal through the fabrication plant and the average production rate of heavy metal scrap materials from the various functional activities. These are presented in Table 9.91.

Given the above information, a preliminary evaluation of the processing rate for each functional step within the main fuel fabrication processes was made. The results of this analysis are summarized in Table 9.92.

\subsubsection{Analysis of Functional Technology Status, Research and Development Requirements, Cost, and Schedule}

The technology status of this system is quite similar to that of the reference case discussed in Sect. 8. The current status and research and development needs are summarized in Table 9.93. The primary difference is between this $\mathrm{UO}_{2}$ fuel and the reference $(\mathrm{U}, \mathrm{Pu})_{2}$ fuel. Development is under way in the United States on sphere forming, calcination, and sintering.

While the functional fabrication processes are the same as those given for the reference gel-sphere-pac fabrication case, the design of the 
Table 9.90. Sphere-Pac Fabrication Plant Surge Storage Requirements and Normal Inventory [NASAP Case 6.5, LMFBR DU(3)/Th Recycle]

\begin{tabular}{|c|c|c|c|c|c|c|}
\hline \multirow{2}{*}{ Process step } & \multirow{2}{*}{ Material } & \multicolumn{2}{|c|}{$\begin{array}{l}\text { Storage } \\
\text { Interval, } \mathrm{d}\end{array}$} & \multicolumn{3}{|c|}{ Normal Inventory, $\mathrm{kg} \mathrm{HM}$} \\
\hline & & Norma1 & Maximum & $\left({ }^{23}{ }^{3} \mathrm{U}, \mathrm{U}\right) \mathrm{O}_{2}$ & $\mathrm{UO}_{2}$ Fines & $\mathrm{ThO}_{2}$ Pellets \\
\hline Feed storage & $\begin{array}{l}\text { Dried spheres } \\
\text { Sintered spheres } \\
\text { Sintered pellets }\end{array}$ & $\begin{array}{l}30 \\
30 \\
30\end{array}$ & $\begin{array}{l}60 \\
60 \\
60\end{array}$ & 32,000 & 8,400 & 9,800 \\
\hline Interim storage & $\begin{array}{l}\text { Dried spheres } \\
\text { Sintered spheres } \\
\text { Sintered pellets }\end{array}$ & $\begin{array}{l}1 \\
1 \\
1\end{array}$ & $\begin{array}{l}2 \\
2 \\
2\end{array}$ & 1,070 & 280 & 330 \\
\hline Furnace & $\begin{array}{l}\text { Dried to sintered } \\
\text { spheres }\end{array}$ & 1.2 & 2.4 & 1,280 & & \\
\hline Post furnace & Sintered spheres & 0.5 & 1 & 530 & & \\
\hline Interim storage & Sintered spheres & 0.36 & 0.72 & 380 & & \\
\hline Main storage & $\begin{array}{l}\text { Sintered spheres } \\
\text { Sintered spheres } \\
\text { Sintered pellets }\end{array}$ & $\begin{array}{l}1.2 \\
1.5 \\
1.5\end{array}$ & $\begin{array}{l}2.4 \\
2.9 \\
2.9\end{array}$ & 1,350 & 420 & 560 \\
\hline $\begin{array}{l}\text { Loading, inspection, } \\
\text { welding }\end{array}$ & $\begin{array}{l}\text { Sintered spheres } \\
\text { and pellets }\end{array}$ & 0.12 & 0.24 & 130 & 35 & 45 \\
\hline $\begin{array}{l}\text { Loaded, not inspected } \\
\text { rods }\end{array}$ & $\begin{array}{l}\text { Sintered spheres } \\
\text { in rods }\end{array}$ & 5 & 5 & 5,300 & 1,330 & 3,720 \\
\hline Rework and scrap & $\begin{array}{l}\text { Sintered spheres } \\
\text { and pellets }\end{array}$ & 2 & 5 & 260 & 50 & 95 \\
\hline Completed fuel rods & $\begin{array}{l}\text { Sintered spheres } \\
\text { and pellets } \\
\text { in rods }\end{array}$ & 5 & 5 & 5,200 & 1,290 & 3,610 \\
\hline Assemb1y & $\begin{array}{l}\text { Rods in completed } \\
\text { assemblies }\end{array}$ & 15 & 30 & 15,400 & 3,850 & 10,800 \\
\hline
\end{tabular}


Table 9.91. Heavy Mctal Mass Flows and Average Scrap Production for a Sphere-Pac Fuel Fabrication Plant [NASAP Case 6.5, LMFBR DU(3)/Th Recycle]

\begin{tabular}{|c|c|c|c|c|c|c|c|c|c|}
\hline \multirow{3}{*}{ Processing step } & \multicolumn{9}{|c|}{ Mass Flow, kg HM/d } \\
\hline & \multirow[b]{2}{*}{ vo' } & \multicolumn{2}{|c|}{ Dally Throughput } & \multicolumn{3}{|c|}{ Clean serapl } & \multicolumn{3}{|c|}{ Reject Scrap } \\
\hline & & $\begin{array}{l}10 \\
\text { Fine's }\end{array}$ & $\begin{array}{l}\text { Axial Blanket } \\
\text { Tho Pellets }\end{array}$ & 10 & $\begin{array}{l}\text { Uo } \\
\text { rists }\end{array}$ & $\begin{array}{l}\text { Axial Blanket } \\
\text { Tho Pillets }\end{array}$ & Uo & $\begin{array}{l}\text { lo } \\
\text { Fines }\end{array}$ & $\begin{array}{l}\text { Axial Blanket } \\
\text { Tho Pellets }\end{array}$ \\
\hline Recexving and storage & 1065.8 & $280.7^{\circ}$ & 720.4 & & & & & & \\
\hline Sampling and batch loading & 1064.7 & & & & & & 1.1 & & \\
\hline Weighting and sampling & & 280.4 & $719.7^{\prime}$ & & & & & 0.3 & 0.7 \\
\hline Calcining and sintering & 1064.2 & & & & & & 0.5 & & \\
\hline Sphere upgrading & $1124.0^{\circ}$ & & & & & & 31.9 & & \\
\hline Sphere sampling & 1121.8 & & & & & & 2.2 & & \\
\hline Interim storage & 1121.8 & 280.4 & 392.3 & & & & & & \\
\hline Fuel rod loadnng & 1121.8 & 280.4 & 392.3 & & & & & & \\
\hline Fuel rod scanning & 1065.7 & 266.4 & 745.5 & 53.8 & 13.5 & 18.8 & 2.2 & 0.6 & 0.8 \\
\hline Top component insertion & 1063.3 & 265.8 & 743.9 & 2.1 & 0.5 & 1.5 & 0.2 & 0.1 & 0.2 \\
\hline Rod weldeng and $x$ ray & 1063.3 & 265.8 & 743.9 & ' & 1 & ' & $n$ & $\dot{r}$ & " \\
\hline Leak detection & 1063.3 & 265.8 & 743.9 & ' & r & ' & $i_{1}$ & $n$ & i. \\
\hline Rod assay & 1042.1 & 260.5 & 729.0 & 20.2 & 5.0 & 14.1 & 1.1 & 0.3 & 0.7 \\
\hline Final rod inspection & 1031.2 & 257.8 & 721.4 & 10.4 & 2.6 & 7.3 & 0.4 & 0.1 & 0.3 \\
\hline Assembly inspection & 1025.9 & 256.5 & 717.7 & 3.2 & -1.3 & 3.6 & $\underline{0.2}$ & 0.1 & $\underline{0.1}$ \\
\hline Total & & 2000 & & 91.7 & 22.9 & 45.4 & 39.9 & 1.3 & 2.7 \\
\hline
\end{tabular}

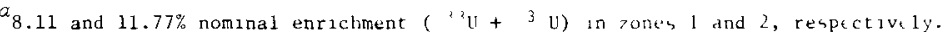

Internally recycled.

${ }^{\circ}$ Collected, assayed, and externally recycled to reprocusung plant.

Includes $22.9 \mathrm{~kg}$ of recycled clean scrap.

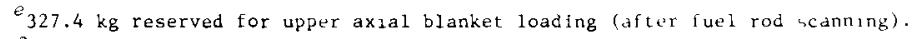

$f_{\text {Includes }} 91.7 \mathrm{~kg}$ of recycled clean scrap.

Includes $45.4 \mathrm{~kg}$ of recycled clean scrap plus $327.4 \mathrm{hg}$ ot irtsh material.

Rework in these steps is only of the weld and does not affut herap. 
Table 9.92. Equipment Requ1rements for Functional Areas [NASAP Case 6.5 LMFBR DU(3)/Th Recycle]

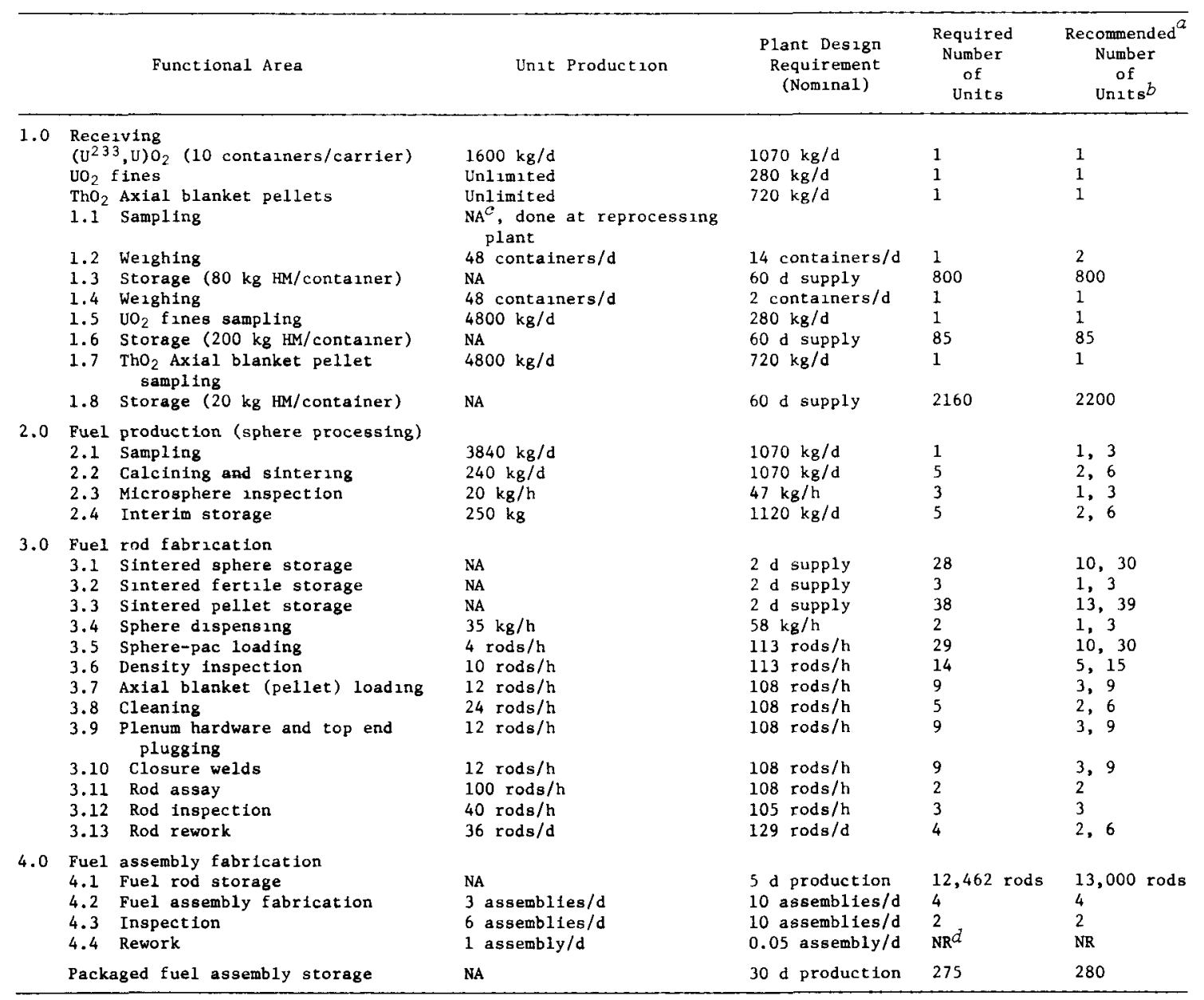

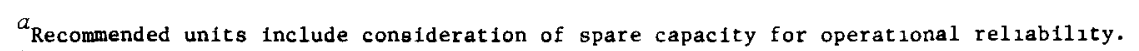

$b$ Number of units is for the facility if a single number, otherwise, units per line, total units in facility.

$c_{\text {NA: }}$ not applicable.

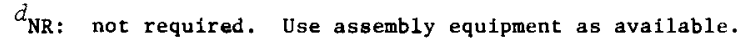


Table 9.93. Research and Development Cost Estimates for Sphere-Pac Fabrication [NASAP Case 6.5 LMFBR DU(3)/Th Recycle]

\begin{tabular}{|c|c|c|c|c|}
\hline & R\&D Categories & Current status ${ }^{\alpha}$ & $\begin{array}{c}\text { R\&D Cost Estimates } \\
\text { (Millions of } \\
1978 \$ \text { ) }\end{array}$ & $\begin{array}{l}\text { Years to } \\
\text { Complete }\end{array}$ \\
\hline 1.0 & Program management & Not applicable & 10 & 10 \\
\hline 2.0 & Design studies & $\mathrm{N}-$ cold engineering & 25 & 10 \\
\hline 3.0 & Receiving and storage & $P-\operatorname{cold}$ engineering & 4 & 5 \\
\hline 4.0 & Fuel production & $P-\operatorname{cold}$ engineering & 30 & 8 \\
\hline 5.0 & Fuel rod fabrication & $P-\operatorname{cold}$ engineering & 55 & 8 \\
\hline 6.0 & Fuel element assemb1y & $\mathrm{N}-\operatorname{cold}$ engineering & 32 & 8 \\
\hline 7.0 & Scrap recovery & $\mathrm{N}$ - hot laboratory & 7 & 6 \\
\hline 8.0 & Waste treatment & $b$ & $b$ & $b$ \\
\hline 9.0 & Plant control systems & $N-\operatorname{cold}$ prototype & 5 & 8 \\
\hline 10.0 & Maintenance & $\mathrm{N}$ - cold prototype & 10 & 10 \\
\hline 11.0 & $\begin{array}{l}\text { Safeguards and account- } \\
\text { ability adaptation }\end{array}$ & $P-$ cold engineering & 6 & 6 \\
\hline & Subtotal & & 184 & \\
\hline \multicolumn{5}{|c|}{ Special Facilities } \\
\hline \multicolumn{2}{|c|}{ Hot tests } & & 10 & \\
\hline \multicolumn{2}{|c|}{ Cold prototype } & & 25 & \\
\hline \multicolumn{2}{|r|}{ Total } & & $219^{d}$ & \\
\hline \multicolumn{2}{|r|}{ Range } & & $210-265$ & \\
\hline $\begin{array}{l}\mathrm{N}= \\
\operatorname{appl} \\
\operatorname{mill}\end{array}$ & $\begin{array}{l}a_{\text {Status stage with qualit }} \\
\text { eeded. } \\
b_{\text {To be supplied by others }} \\
c_{\text {Assumes basic technology }} \\
\text { cations testing, systems } \\
d_{\text {The estimate does not in }} \\
\text { on) or the capital costs }\end{array}$ & $\begin{array}{l}\text { tive modifiers; } \mathrm{C}=\mathrm{cor} \\
\text { as developed under oss } \\
\text { ategraton, and testing } \\
\text { lude costs for fuel qu } \\
\text { f a pilot plant estima }\end{array}$ & $\begin{array}{l}\text { plete, } P=\text { in progre } \\
\text { estimate presented } \\
\text { lification tests }(a) \\
\text { ed at } \$ 220 \text { million. }\end{array}$ & $\begin{array}{l}\text { s, and } \\
\text { for } \\
\text { ut } \$ 20\end{array}$ \\
\hline
\end{tabular}


LMFBR fuel elements is considerably different. These differences in design result in modifications to the details for accomplishing the various functional activities and modifications to the facility design details. In the subsequent paragraphs, each of the functional activities is discussed as it applies to this case.

A ge1-sphere-pac functional flow diagram is given in Fig. 3.1 of Sect. 3.1.1 of this report. The major functional areas apply to this case, and the two main functions unique to the ge1-sphere-pac process are fuel production (2.0) and fuel rod fabrication (3.0). All the functional steps are briefly discussed here.

Receiving and Storage. This functional area is quite similar to the reference case. However, in addition to the spheres, the $\mathrm{ThO}_{2}$ pellets from the adjacent radial blanket assembly plant must be received, inspected, and stored.

Fuel Production. The fuel production processes for the spheres are essentially the same as those described for the reference case including calcination, sintering, and inspection of the two coarse sizes which contain $233 \mathrm{U}$. No processing is planned for the $\mathrm{UO}_{2}$ fines because they are to be sintered at the reprocessing conversion step. However, because the $\mathrm{ThO}_{2}$ axial blanket pellets make up approximately $36 \%$ of the total heavy metal content in a core fuel assembly, the quantity of coarse and medium spheres processed is significantly less than in the reference case.

Fuel Rod Fabrication. While most of the fuel rod fabrication processes are similar to the reference case, additional steps are required to incorporate the axial blanket material. The lower axial blanket section is loaded into the fuel rod cladding before the cladding is introduced into the cell. After the $\left(23 \mathrm{U}^{\mathrm{U}}, \mathrm{U}\right) \mathrm{O}_{2}$ core region is loaded by the spherepac process into each rod and inspected for density, the upper axial blanket section will be loaded by equipment similar to that used for inserting plenum hardware. The actual plenum hardware insertion and end cap welding operations are essentially the same as those described for the reference case.

Fuel Assembly Operations. The fuel assembly design for this LMFBR case 6.5 is identical to that for the pellet fabrication option. Following fuel rod inspection each rod will be remotely wrapped with a 
wire. This special wire wrap will space the fuel rods in the assembly. Groups of these rods are assembled onto T-bars of varying length. The T-bar strip layers are assembled and fastened to the lower end box of the fuel assembly. The duct tube is installed and the finished assembly is inspected.

Product Control Processes. These are the same as the reference case (see Sect. 4.1.2).

Scrap and Waste Processing and Disposal. The scrap hand1ing processes are similar to the reference case (see Sect.4.1.2) with the added feature that all axial blanket pellets that are unloaded from an unsatisfactory rod are inspected, and acceptable pellets are recycled within the remotely operated part of the facilities to form upper axial blankets.

\subsubsection{Preliminary Cost Estimate for Construction and Operation of a Commercial-Scale Plant}

The cost components that were estimated include capital costs for the facility and equipment, fuel assembly hardware costs, material and supply costs, and operating costs.

Facility capital cost estimates were based on an analysis of the functional flow diagram for the process to indicate space requirements for each functional area and for each support area. Equipment requirements were identified, and costs associated with the equipment were estimated. Fuel assembly hardware requirements were based on the reference fuel assembly design parameters identified in Table 9.89. Estimates of the costs of the hardware items were obtained. Material and supply requirements were identified from the sphere-pac process description, and estimates of the costs of materials and supplies were obtained. Operating cost estimates included consideration of personnel, overhead, general and administrative expenses, and costs of utilities.

The facility was assumed to operate as a toll processing facility. That is, the operator fabricates customer-supplied fuel feed materials into finished fuel assemblies, and thus costs of uranium were not included in the cost estimates. The hardware and material costs do include the costs associated with the production of the $\mathrm{ThO}_{2}$ pellets for the axial blankets. 
Unit costs for fabrication of fuel assemblies are determined by an economic analysis of the basic capital, hardware and material, and operating cost estimates. Basically, the economic analysis provides for the owner of the fuel fabrication facility to recover all capital, operating, and finance charges plus a return on investment, if appropriate, over the life of the plant. In order to provide a range of prices (i.e., costs to a customer), economic analyses were based on government financing, financing appropriate for a conventional-risk (typical) industry, and financing appropriate for a high-risk industry. 2 The estimated costs, costs derived from the economic analysis, and the unit costs based on the three different financing methods are summarized in Table 9.94. As may be observed from the table, the price for fabrication of $\mathrm{UO}_{2}-\mathrm{ThO}_{2}$ fuel is expected to be in the range from $\$ 420$ to $\$ 890 / \mathrm{kg}$ depending on the financing technique that is employed. The recommended cost for comparison with other fuel cycles and methods of fabrication is the typical industry cost of $\$ 700 / \mathrm{kg}$ of heavy metal. As with all the cost estimates in this report, the prices are based on the mass of all heavy metal in the finished assembly. For this case, this includes the thorium in the axial blankets. 
Table 9.94. Summary of Costs for Fabrication of Sphere-Pac PWR Fuel in a 2-t HM/d Facility [NASAP Case 6.5, LMFBR DU(3)/Th Recycle]

\begin{tabular}{|c|c|c|c|c|c|c|c|c|c|}
\hline \multirow[b]{2}{*}{$\begin{array}{c}\text { Economic } \\
\text { Set }^{a}\end{array}$} & \multicolumn{4}{|c|}{ Estimated Costs, \$ million } & \multicolumn{4}{|c|}{ Derived Costs, $\$$ million } & \multirow[b]{2}{*}{$\begin{array}{l}\text { Unit } \\
\text { Cost } \\
(\$ / \mathrm{kg})\end{array}$} \\
\hline & Facility & Equipment & $\begin{array}{l}\text { Annual } \\
\text { Hardware } \\
\text { P1us } \\
\text { Materials }\end{array}$ & $\begin{array}{c}\text { Annual } \\
\text { Operating }\end{array}$ & $\begin{array}{c}\text { Owner's } \\
\text { Cost } \\
\text { During } \\
\text { Construction }\end{array}$ & $\begin{array}{c}\text { Charge on } \\
\text { Direct Capital } \\
\text { During } \\
\text { Construction }\end{array}$ & $\begin{array}{c}\text { Annual } \\
\text { Equipment } \\
\text { Replacement } \\
\text { Cost }\end{array}$ & $\begin{array}{c}\text { Annual } \\
\text { Payment to } \\
\text { Decommissioning } \\
\text { Fund }\end{array}$ & \\
\hline A & 395 & 325 & 54 & 28 & 41 & 190 & 16 & 1.3 & 420 \\
\hline B & 395 & 325 & 54 & 29 & 42 & 280 & 16 & 1.3 & 700 \\
\hline $\mathrm{C}$ & 395 & 325 & 54 & 30 & 43 & 280 & 16 & 1.4 & 890 \\
\hline
\end{tabular}

$a_{\mathrm{A}}=$ Government financing; $\mathrm{B}=$ Typical industrial financing; $\mathrm{C}=$ High-risk industrial financing.

$b$ These unit costs apply only to the core fuel elements. The associated radial blanket costs are $\$ 95$, $\$ 120$, and $\$ 140$ for economic sets $A, B$, and $C$, respectively. 


\subsection{REFERENCES}

1. R. R. Judkins and A. R. Olsen, Estimation of Costs for Fabrication of Pressurized Water Reactor Fuels, ORNL/TM-6501 (January 1979).

2. A. R. Olsen, R. R. Judkins, W. L. Carter, and J. G. Delene, Fuel Cycle Cost Studies - Fabrication, Reprocessing, and Refabrication of LWR, SSCR, HWR, LMFBR, and HTGR Fuels, ORNL/TM-6522 (March 1979).

3. R. R. Judkins and A. R. 01sen, Nuclear Fuel Fabrication and Refabrication Cost Estimation Methodology, ORNL/TM-6640 (in preparation).

4. A. L. Lotts et al., Fast Breeder Reactor Oxide Fuels Development Final Report, ORNL-4901 (November 1973).

5. P. F. Sens and E.B.M. Majoor, "Irradiation Behavior of Vibrasol Fuel," pp. 152-60 in Nuclear Energy Maturity, Vol. 3, Nuclear Fuel Performance and Management Part I. (Proc. European Nucl. Conf., Paris, April 21-25), 1975, Pergamon, Oxford, 1976.

6. Safety Analysis Report for the Light Water Reactor Breeder, Shippingport Atomic Power Station, Vols. 1-10. 


\section{SUMMARY AND CONCLUSIONS}

Although all current commercial metal-clad fuel fabrication in the United States is by the pellet process, various fabrication process options are under development. Gel-sphere-pac fuel is receiving extensive consideration because of possible improved in-reactor performance characteristics, particularly reduced fuel-cladding mechanical interaction, and advantages associated with fuel processing since the spheres can be transported pneumatically in enclosed equipment from one process step to the other. There is also a potential economic advantage for fabrication of fuels that contain $\mathrm{Pu}, 233 \mathrm{U}$, or spikes, which will require that the process be remotely operated and, in most instances, that the processing equipment be remotely maintained.

The gel-sphere-pac fuel fabrication option was evaluated along with its possible application to 19 fuel element designs that use oxide fuel in metal-clad rods. The primary evaluation was for a light-water-reactor fuel element containing $(\mathrm{U}, \mathrm{Pu})_{2}$ fuel. The other 18 fuel element types 3 for light-water reactors, 1 for a heavy-water reactor, 1 for a gascooled fast reactor, 7 for liquid-metal-cooled fast breeder reactors, and 3 pairs for light-water prebreeder and breeder reactors - were evaluated by comparison with the light-water reactor.

We have defined and evaluated all fuel fabrication process steps from fuel receiving to finished fuel element shipping. Our evaluation also covers the feasibility of the process, the current status of technology, estimates of the required time and cost to develop the technology to commercial status, and the safety and licensability of commercial-scale plants.

The plant design concept addresses only those processes directed toward the fabrication or refabrication of fuel assemblies. Processes are limited to the production of sintered spheres, loading of fuel rods, assembly of these rods into finished assemblies, and the supporting activities necessary to perform these steps in a safe licensable commercial facility. 
The sphere-pac process depends on the reprocessing plant conversion product for its primary fuel feed component (as does the pellet process). However, this feed material differs in form from the pellet process. The pellet process uses dry oxide powders, which are subsequently blended and conditioned for process feed within the fabrication plant. The sphere-pac process feed consists of free-flowing, spherical, homogeneous particles, which are formed in the product conversion process step of the reprocessing plant and which need only sintering to high density to be suitable for fuel rod loading. The fissile spheres are obtained in two sizes, coarse (nominally $1200 \mu \mathrm{m}$ in diameter) and medium (nominally $200 \mu \mathrm{m}$ in diameter). In addition, fertile material in the form of very small (nominally 40- $\mu \mathrm{m}$-diam) spheres is used in the process. These "fertile fines" can be produced with an auxiliary process support activity in the refabrication plant or purchased from a supplier. In the contact-operated cases, which do not involve reprocessed fuel, the gel forming and drying operations are included as part of the fabrication plants. Hardware components, such as fuel rod cladding and material for the assembly skeletons, are purchased from outside suppliers.

The ge1-sphere-pac process uses high-density spheres of the required fuel composition. In the fabrication plants described in this report these dry gel spheres are calcined, sintered, inspected, and then loaded into fuel rods and packed by low-energy vibration. The resulting fuel bed will achieve a fuel smear density of 83 to $88 \%$ of theoretical.

\subsection{PROCESS DESCRIPTION}

The dried spheres of the required fuel composition are received from the reprocessing plant or auxiliary sphere forming operation in combined shipping and storage cannisters. After appropriate sampling and analysis a11 feed material is stored in a safeguarded vault. Cannisters are withdrawn from storage as required and entered into the processing operation. 
Material from a single cannister is poured through a mechanical splitter-loader, which subdivides the contents and distributes the material into molybdenum boats for calcining and sintering. Calcining and sintering, together with the adjustment of the oxygen-to-metal ratio, are done in a continuous furnace. From the time the dried spheres enter the furnace until they are loaded into the fuel rods the fuel material is contained within the process equipment in a controlled atmosphere.

At the exit of the cooling zone following the furnace, the boats are mechanically unloaded into a hopper, which feeds a sphere upgrading system. There the spheres are screened and shape-separated to remove oversize, undersize, and broken material. The good material is passed through a splitter sampler and the batch is collected in a transfer hopper pending quality control approval. Acceptable material is pneumatically transferred to storage hoppers, which provide production surge capacity between the sphere sintering and fuel rod loading areas of the process.

The three sizes of spheres are transferred pneumatically from the appropriate storage hoppers to a volumetric dispensing station. Material suitable for a single fuel rod loading is dispensed to vibratory feeders, which control the rate of flow of each sphere size into the fuel rod. The fuel rod cladding, with a bottom end cap welded in place, is clamped to a low-energy vibrator at the loading station. The rod is vibrated during and after the loading to pack the bed to the required density. The loaded fuel rods are then scanned with a gamma densitometer before final internal component loading and welding of the top end cap.

Fuel rods are fabricated vertically but are rotated to a horizontal position at the $x$-ray rack loading station. Subsequent handling is in a horizontal orientation with support along the rod to prevent mechanical deformation. Following the closure, x-ray inspection, and helium leak testing, any rods with external surface contamination are decontaminated before they are transferred to the final inspection and element assembly area.

An isolated area for rework and internal recycle of fuel and fuel rods is provided for each fuel rod fabrication line to prevent mixing of different-assay materials. Functions include removal of end plugs from 
defective welds, total disassembly of fuel rods, recovery of fuel with subsequent screening and sorting for recycle, and accumulation of reject materials to be returned to the reprocessing plant for total recycle.

Since only a limited number of elements per day are produced at full capacity, a common manufacturing area can accommodate the output from all three fuel rod fabrication lines. This area is separated from the fuel rod fabrication areas, and this separation provides additional protection against accidental contamination of the exterior surfaces of the finished assembly. The area includes surge storage for the fuel rods as well as equipment for their final inspection and nondestructive assay. Equipment that loads the fuel rods into the assembly skeleton, inspects the finished assembly, and places it in a shipment support package completes the contents of this area.

The final area in the direct manufacturing process line is the storage vault and shipping location for completed assemblies. The vault is similar to but smaller than the fuel receiving storage vault. Space and equipment for loading the shipping containers and placing these on the appropriate off-site carrier are provided near the vault.

Al1 liquid waste from activities within the controlled plant area are collected and monitored for plutonium and uranium contents. Only the liquid from treated sewage is discharged from the plant. Other lowcontamination-level liquids are treated for recovery and recycle. Excess water is discharged as a vapor in the ventilation exhaust. Liquids with significant quantities of heavy metal are chemically processed to recover the uranium and plutonium and to concentrate other contained solids and salts. These liquids include the analytical laboratory wastes, decontamination solutions, and solutions from leaching of highly contaminated wastes such as the filters, as well as the concentrated low-level wastes. The resulting alpha-contaminated concentrates are immobilized in concrete or glass. All solid waste is placed in appropriate shipping and disposal containers, assayed, and sent to treated waste storage before of $f$-site shipment. All process equipment in the waste treatment area is contained within controlled areas to confine and test all gaseous effluents before release to the plant exhaust system and the stack. 


\subsection{TECHNOLOGY STATUS}

The sphere formation and sphere-pac concepts were originated in the United States about 20 years ago, and the technology was vigorously pursued until mid-1972. Subsequently, the concepts have been studied and refined (predominantly in Europe). The High Temperature Gas-Cooled Reactor development efforts in the U.S. have provided continuing effort on sphere forming and material handling. This development includes sphere sizing, shape separation, handling, transport, dispensing, sampling, and inspection. During the past year significant progress has been made on simultaneous loading processes, which eliminate the older, time-consuming infiltration of the fine spheres into the bed of coarse and medium spheres.

This evaluation has firmly established technical feasibility for each process step. In most instances the process steps are we11-defined, and equipment and processes are being refined. Additional development is required to establish and proof test the design of commercial-scale equipment. The costs of this development for each case if done separately are presented in Table 10.1. The estimates range from $\$ 77$ million for spherepac fabrication of light-water reactor fuel elements containing lowenriched $\mathrm{UO}_{2}$, with no fuel element assembly development required, to approximately $\$ 250$ million for light-water breeder reactor fuel elements with significant fuel element assembly development and a requirement for remotely operated and remotely maintained equipment throughout the fabrication plant. The estimated time required for development is from six to ten years.

Our preliminary assessment of the processes and the facilities indicates that no unusual environmental, safety, or materials safeguarding measures are needed. Commercial-scale plants can be designed and constructed to meet current U.S. licensing requirements. 
Table 10.1. Summary of Research and Development Cost Estimates for the Gel-Sphere-Pac Fuel Fabrication Process

\begin{tabular}{|c|c|c|c|c|}
\hline \multirow{2}{*}{$\begin{array}{l}\text { Reactor and } \\
\text { Fuel Type }\end{array}$} & \multirow{2}{*}{$\begin{array}{l}\text { NASAP } \\
\text { Case }\end{array}$} & \multicolumn{2}{|c|}{ R\&D Estimates } & \multirow{2}{*}{$\begin{array}{l}\text { Estimated } \\
\text { Pilot Plant } \\
\text { Capital Need } \\
\quad\left(\$ 10^{6}\right)\end{array}$} \\
\hline & & $\begin{array}{c}\operatorname{Cos} t \\
\left(\$ 10^{6}\right)\end{array}$ & $\begin{array}{l}\text { Years to } \\
\text { Complete }\end{array}$ & \\
\hline \multicolumn{5}{|l|}{$\underline{\mathrm{PWR}}$} \\
\hline$\left({ }^{235} \mathrm{U}, \mathrm{U}\right) \mathrm{O}_{2}$ & 1.2 & 77 & 6 & $b$ \\
\hline$(\mathrm{U}, \mathrm{Pu}) \mathrm{O}_{2}$ Spiked & 1.3 & 210 & 10 & 190 \\
\hline$(233 \mathrm{U}, \mathrm{U}) \mathrm{O}_{2}$ & 1.4 & 211 & 10 & 190 \\
\hline$(\mathrm{U}, \mathrm{Pu}) \mathrm{O}_{2}$ & 1.5 & 175 & 8 & 140 \\
\hline \multicolumn{5}{|l|}{$\underline{\mathrm{HWR}}$} \\
\hline$\left(235_{U}, U\right) O_{2}$ & 2.1 & 69 & 5 & $b$ \\
\hline \multicolumn{5}{|l|}{$\underline{\text { LWBR }}$} \\
\hline MEU(5)-Th Prebreeder & 3.1 .1 & \multicolumn{2}{|c|}{ Not applicable } & \\
\hline $\begin{array}{l}\text { HEU(3)-Th Advanced } \\
\text { Breeder }\end{array}$ & 3.1 .2 & 238 & 10 & $c$ \\
\hline MEU(5)-Th Prebreeder & 3.2 .1 & \multicolumn{2}{|c|}{ Not applicable } & \\
\hline HEU(3)-Th Breeder & 3.2 .2 & 238 & 10 & $c$ \\
\hline HEU(5)-Th Prepreeder & 3.3 .1 & 80 & 5 & $b$ \\
\hline HEU(3)-Th/Th Breeder & 3.3 .2 & 240 & 10 & c \\
\hline \multicolumn{5}{|l|}{ GCFR } \\
\hline$(\mathrm{U}, \mathrm{Pu}) \mathrm{O}_{2} / \mathrm{ThO}_{2}$ & 5.1 & 232 & 10 & 160 \\
\hline \multicolumn{5}{|l|}{$\underline{\text { LMFBR }}$} \\
\hline$(\mathrm{U}, \mathrm{Pu}) \mathrm{O}_{2} / \mathrm{UO}_{2}$ & 6.1 & 195 & 10 & 160 \\
\hline$(\mathrm{U}, \mathrm{Pu}) \mathrm{O}_{2} / \mathrm{UO}_{2}$ & 6.2 .1 & 195 & 10 & 160 \\
\hline$(\mathrm{U}, \mathrm{Pu}) \mathrm{O}_{2} / \mathrm{UO}_{2}$ & 6.2 .2 & 195 & 10 & 160 \\
\hline$(\mathrm{U}, \mathrm{Pu}) \mathrm{O}_{2} / \mathrm{UO}_{2}$ & 6.3 .1 & 195 & 10 & 160 \\
\hline$(\mathrm{U}, \mathrm{Pu}) \mathrm{O}_{2} / \mathrm{ThO}_{2}$ & 6.3 .2 & 196 & 10 & 170 \\
\hline$(\mathrm{Pu}, \mathrm{Th}) \mathrm{O}_{2} / \mathrm{ThO}_{2}$ & 6.4 & 219 & 10 & 240 \\
\hline$\left({ }^{233} \mathrm{U}, \mathrm{U}\right) \mathrm{O}_{2} / \mathrm{ThO}_{2}$ & 6.5 & 219 & 10 & 220 \\
\hline
\end{tabular}

$a_{\text {Assumed }} 1$ ffetime of 10 years, full-scale equipment test, approximately $10 \%$ of mature plant capacity. Operating costs will be compensated for with fuel value. Fuel will be used in pilot and demonstration reactors.

$b_{\text {Not }}$ required.

${ }^{c}$ Insufficient information was available to fully define the requirements for fabrication of these fuel elements. 


\subsection{COST ESTIMATES FOR COMMERCIAL FACILITIES}

In assessing the applicability of this process to the given fuel element designs for the 19 cases addressed in this analysis, the ge1sphere-pac process was suitable for all but 2 cases. The two LWBR cases for which the process was not suitable contained duplex fuel in which a $\mathrm{ThO}_{2}$ core was surrounded by a $\mathrm{UO}_{2}$ annulus. In several other cases design fuel smear densities exceeded the currently achievable gel-sphere-pac maximum density ( 83 to $88 \%$ ) by 2 to $3 \%$. However, we felt that changes in design to accomodate this limitation were possible and that the ge1sphere-pac process might still be suitable in these cases.

To quantitatively evaluate the refabrication plants described in this report, certain design characteristics were defined:

1. The plant production capacities are $480 \mathrm{t} \mathrm{HM} /$ year and $520 \mathrm{t}$ HM/year for remotely operated and contact-operated plants, respectively. Each plant has the capability of simultaneous1y producing fuels of three different assay levels.

2. The plant factors are 240 and 260 effective full-production days per year for remotely operated and contact-operated plants, respectively.

3. Plant design capacity:

$\begin{array}{ll}\text { Overall } & 730 \mathrm{t} \mathrm{HM} / \text { year } \\ & 2 \mathrm{t} \mathrm{HM} / \mathrm{d} \\ \text { Each 1ine of three } & 243 \mathrm{t} \mathrm{HM} / \text { year } \\ & 0.67 \mathrm{t} \mathrm{HM} / \mathrm{d}\end{array}$

4. Process design capacities are based on the line design capacities, equipment availability, and scrap and sample losses.

5. The facilities are designed to discharge no liquid waste other than treated sanitary sewage.

6. All process buildings and critical auxiliary support are designed and constructed in accordance with the current U.S. Nuclear Regulatory Commission requirements.

The plants are operated as commercial facilities with three shifts per day, seven days per week. Both operating and maintenance personnel are available on all four shifts, although there are some increases in the day-shift complement five days per week. 
A11 process operations in the facilities are to be mechanized. Internally recycled scrap materials are reworked within a designated process area for each fuel rod line to provide enrichment control. All fuel materials recovered in the waste treatment process are converted to solid oxides before return to the reprocessing plant for recycle.

Around, above, below, and adjacent to the direct manufacturing process areas are sites for process control. These include such off-1ine activities as process control operating areas and analytical laboratories for sample analyses for process control, product quality assurance, and confirmation of plant effluent control monitoring. Significant space is provided for process equipment maintenance, decontamination, and confinement of contamination. Space is also provided for process services, for material movements with limited local storage, and for special ventilation equipment and controls. Also located within this main process building is an area for safeguards and accountability monitoring and control. Appropriate computer and limited office space for process management personnel is provided.

Each plant estimate included the cost of land acquisition, site preparation, perimeter fencing, road and railroad access, an administration and engineering building, and the usual warehouses and maintenance facilities.

The ge1-sphere-pac option was found to be directly applicable to 17 of the 19 fuel element types. The characteristics of a commercial-scale plant were defined for each specific design. These characteristics were then used as a basis for making cost estimates for the plants. These cost estimates, which include both capital and operating costs, are summarized in Table 10.2. When these costs estimates are subjected to a financial analysis, estimated prices for the commercial fabrication of such fuel elements are obtained. These estimated prices are then suitable for comparison with similar estimates made for fabrication using the conventional pellet process. 1 
Table 10.2. Summary of Mature Industry Gel-Sphere-Pac

Fuel Fabrication Plant Cost Estimates

\begin{tabular}{|c|c|c|c|c|c|c|}
\hline \multirow{2}{*}{ Reactor Fuel } & \multirow{2}{*}{$\begin{array}{l}\text { NASAP } \\
\text { Case }\end{array}$} & \multirow{2}{*}{$\begin{array}{l}\text { Approximate } \\
\text { Reactor } \\
\text { Support }\end{array}$} & \multicolumn{4}{|c|}{ Estimated Costs, $\$$ Million } \\
\hline & & & Facility & Equipment & $\begin{array}{l}\text { Annual } \\
\text { Materials }\end{array}$ & $\begin{array}{l}\text { Annual } \\
\text { Operating }\end{array}$ \\
\hline \multicolumn{7}{|l|}{$\underline{\mathrm{PWR}}$} \\
\hline$(235 \mathrm{U}, \mathrm{U}) \mathrm{O}_{2}$ & 1.2 & 20 & 31 & 35 & 25 & 13 \\
\hline$(\mathrm{Pu}, \mathrm{U}) \mathrm{O}_{2} \quad($ Spiked $)$ & 1.3 & 18 & 360 & 260 & 30 & 25 \\
\hline$\left({ }^{233} \mathrm{U}, \mathrm{Th}\right) \mathrm{O}_{2}$ & 1.4 & 20 & 360 & 260 & 33 & 26 \\
\hline$(\mathrm{Pu}, \mathrm{U}) \mathrm{O}_{2}$ & 1.5 & 18 & 250 & 200 & 30 & 24 \\
\hline \multicolumn{7}{|l|}{$\underline{\mathrm{HWR}}$} \\
\hline$\left(235_{\mathrm{U}, \mathrm{U}}\right) 0_{2}$ & 2.1 & 10 & 20 & 34 & 12 & 11 \\
\hline \multicolumn{7}{|l|}{$\underline{\text { LWBR }}$} \\
\hline MEU(5)-Th Prebreeder & 3.1 .1 & & $b$ & $b$ & $b$ & $b$ \\
\hline $\begin{array}{l}\text { HEU(3)-Th Advanced } \\
\text { Breeder }\end{array}$ & 3.1 .2 & & $b$ & $b$ & $b$ & $b$ \\
\hline MEU(5)-Th Prebreeder & 3.2 .1 & & $b$ & $b$ & $b$ & $b$ \\
\hline HEU (3)-Th Breeder & 3.2 .2 & & $b$ & $b$ & $b$ & $b$ \\
\hline HEU(5)-Th Prebreeder & 3.3 .1 & 22 & 34 & 39 & 28 & 14 \\
\hline HEU(3)-Th/Th Breeder & 3.3 .2 & & $b$ & $b$ & $b$ & $b$ \\
\hline \multicolumn{7}{|l|}{ GCFR } \\
\hline$(\mathrm{Pu}, \mathrm{U}) \mathrm{O}_{2} / \mathrm{ThO}_{2}$ & 5.1 & 30 & 250 & 265 & 64 & 25 \\
\hline \multicolumn{7}{|l|}{ LMFBR } \\
\hline$(\mathrm{Pu}, \mathrm{U}) \mathrm{O}_{2} / \mathrm{UO}_{2}$ & 6.1 & 28 & 260 & 255 & 66 & 25 \\
\hline$(\mathrm{Pu}, \mathrm{U}) \mathrm{O}_{2} / \mathrm{UO}_{2}$ & 6.2 .1 & 28 & 260 & 255 & 60 & 25 \\
\hline$(\mathrm{Pu}, \mathrm{U}) \mathrm{O}_{2} / \mathrm{UO}_{2}$ & 6.2 .2 & 28 & 260 & 255 & 66 & 25 \\
\hline$(\mathrm{Pu}, \mathrm{U}) \mathrm{O}_{2} / \mathrm{UO}_{2}$ & 6.3 .1 & 28 & 260 & 255 & 60 & 25 \\
\hline$(\mathrm{Pu}, \mathrm{U}) \mathrm{O}_{2} / \mathrm{ThO}_{2}$ & 6.3 .2 & 29 & 280 & 270 & 68 & 25 \\
\hline$(\mathrm{Pu}, \mathrm{Th}) \mathrm{O}_{2} / \mathrm{ThO}_{2}$ & 6.4 & 27 & 454 & 354 & 64 & 27 \\
\hline$\left({ }^{233} \mathrm{U}, \mathrm{U}\right) \mathrm{O}_{2} / \mathrm{ThO}_{2}$ & 6.5 & 26 & 395 & 325 & 54 & 26 \\
\hline
\end{tabular}

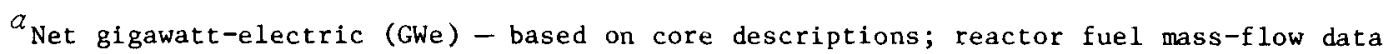
were not available.

${ }^{b}$ Insufficient information provided to fully define plants. 
10.4 CONCLUSIONS

This evaluation clearly shows the ge1-sphere-pac process to be a viable fuel fabrication option. For the contact-operated and contactmaintained facilities and the remotely operated and contact-maintained facilities, the estimates suggest only minor cost advantages for the gel-sphere-pac process (in one instance a minor cost advantage is indicated for the pellet process). Based on our confidence in the estimates, we feel that no significant differences in costs exist for these cases. However, the estimates indicate a significant fabrication cost advantage for the ge1-sphere-pac process if a remotely operated and remotely maintained fuel fabrication plant is required. For remotely operated and remotely maintained plants the estimates indicate that the gel-sphere-pac fabrication process could be 12 to $25 \%$ less expensive than the pellet process for the same design fuel elements. Although this differential is within the accuracy of the cost estimates $( \pm 25 \%)$, the consistency of the estimates is such that the relative cost (or cost differentials) are considered to be significantly more valid than the absolute values of the estimates.

\subsection{REFERENCE}

1. A. R. O1sen, R. R. Judkins, W. L. Carter, and J. G. Delene, Fuel Cycle Cost studies - Fabrication, Reprocessing, and Refabrication of LWR, SSCR, HWR, LMFBR, and HTGR Fuels, ORNL/TM-6522 (March 1979). 
APPENDIX: DESCRIPTION OF THE SPHERE-CONVERSION PROCESS

An alternative to conventional conversion processes is sphereconversion, which uses a gel-sphere process to prepare a free-flowing starting material made of gel spheres. These spheres are suitable for sintering to high density and direct loading into fuel pins and packing by using low-energy vibration. Loading spheres directly into fuel pins and packing by using low-energy vibration is called the gel-sphere-pac process.

\section{A.1. FLOWSHEET AND PROCESS DESCRIPTION}

Sphere conversion is based on three major steps: (1) preparation of a special solution ("broth"), (2) gelation of broth droplets to give semirigid spheres, and (3) washing and drying to give a dry gel-sphere product suitable for shipping to a fuel refabrication plant. Gelation is accomplished chemically by the use of ammonia, which is formed within the broth droplet by hexamethylenetetramine decomposition. This method is called internal gelation. Gelation may also be accomplished externally by using ammonia gas and ammonium hydroxide. This method is called external gelation. Internal gelation is the process that has been selected for discussion in this report and is widely known throughout Europe as the KEMA process. 1 This process is currently being developed in the U.S. under the sponsorship of the DOE Fuel Refabrication and Development program at the Oak Ridge National Laboratory. 2-4

A generic functional flow diagram for sphere conversion is shown in Fig. A.1. Note that various mixtures of uranium and plutonium can be prepared by adjusting the heavy metal feed material. Similarly, by using spiked feeds highly radioactive fuel cycle options can be accommodated. Therefore, the flowsheet in Fig. A.l represents the preparation of mixed $(\mathrm{U}, \mathrm{Pu})_{2}$ fuel for fabrication plants in this study. Although the flowsheets and discussions are intended to describe the preparation of larger gel spheres, they apply also to the preparation of fertile fines, which are made in a contact facility. 


\section{A.1.4 Forming and Washing of Spheres}

This operation requires forming spherical droplets of broth, gelation to form gel spheres, and washing to remove urea, nitrates, and amine before drying. Droplet formation is accomplished by a droplet generator. The process step must yield very high percentages of spherical product in a narrow size range; therefore, a pulsed nozzle is generally used. The wash procedure must remove a majority of the organics and nitrates and give a product that is capable of sintering to high density and provide gel spheres that can be handled during drying and pneumatic transfer.

Droplets of broth are formed in a heated organic, which causes both sphere formation and gelation. Gelation occurs as a result of the heated organic, thus causing amine decomposition to ammonia, which directly causes broth gelation. Washing of the gel spheres is accomplished by the use of dilute ammonium hydroxide.

\section{A. 1.5 Drying of Spheres}

This step requires drying wet gel spheres while maintaining them intact. The dry product must be strong enough for pneumatic transfer and must be capable of sintering to high density (while remaining intact) for sphere-pac applications.

\section{A.1.6 Sphere Inspection}

This process step is required to ensure that the required quality specifications for the dry gel-sphere product are met before shipment to the fuel fabrication plant. Reject material is recycled through the reprocessing plant scrap recovery system. Scrap recovery at this point in the system should be relatively easy since only dried (and not sintered) material is being rejected.

The spheres would be inspected for the following: impurities, sphericity, size distribution, and composition (fissile content). Development needs include faster techniques for size, size distribution, 
and sphericity determination (particularly with respect to fine fertile spheres made in contact facilities).

A. 2 STATUS OF TECHNOLOGY AND RESEARCH AND DEVELOPMENT REQUIREMENTS

\section{A. 2.1. Scope}

The uranium, thorium nitrate, and in some cases the plutonium nitrate products of the solvent extraction step are converted to oxides. The metal oxides are of reactor-grade quality; they are fabricated into fuel elements in an adjacent facility or are shipped to a fabrication plant at a remote site. The internal gelation method for making spheres has been used as the basis for this study.

\section{A. 2.2 Status}

The gelation techniques for preparing spheres for reactor fuels is based on the many man years of study of the sol-gel program, which started 20 years ago and continued to 1971. Methods for preparing stable sols and for converting them to gels and the characteristics of these systems were defined in that program. Studies in this country and in Europe have developed additional methods for preparing sols and gels and methods of preparing, stabilizing, drying, and classifying gel spheres prepared from the sols. Small-scale nonintegrated engineering equipment $(0.5$ to $1 \mathrm{~kg} / \mathrm{h})$ is being used to prepare urania spheres for evaluation and to define the effects of operational variables. This equipment has been used to demonstrate the preparation of thoria and urania-thoria spheres. Gram quantities of plutonia spheres have been made in glove-box experiments.

\section{A.2.3. Development Required}

To produce high-density sphere-pac fuel elements, spheres of three uniform sizes and of essentially theoretical density are required. 
Spheres of very high density and very good physical characteristics have been prepared from all desired combinations of thoria, urania, and plutonia in laboratory experiments (with the exception of thoriumplutonium, which has not yet been investigated). Extensive research and development is required to define process conditions and provide engineering-scale equipment. Conditions for each size fraction and for each metal composition - U, Th, Pu, U-Pu, U-Th, and Th-Pu - may be different. Each operating step will need to be developed and then the steps integrated into a system. Studies have shown that the conditions for each step influence the conditions required for each following step. Conditions also vary with the size of the sphere required. Obtaining very small spheres of uniform size is especially difficult. All processing equipment must be capable of remote operation, and much of the equipment must be remotely maintainable as well.

Only limited development has been completed in control instruments. Additional studies are also required in the washing, drying, calcining, and waste recovery operations.

To meet safeguards requirements methods must be developed so that the amount of material in all parts of the operating equipment can be accurately known.

\section{A.2.4 Research and Development Cost Estimate}

Table Al was extracted from the studies on conversion processes for the reprocessing plant. It provides a yearly cost estimation for the development of the sphere-formation process for $(\mathrm{U}, \mathrm{Pu})_{2}$ fuels. Similar research and development is required for $\mathrm{UO}_{2},(\mathrm{U}, \mathrm{Th}) \mathrm{O}_{2}$, and $(\mathrm{Pu}, \mathrm{Th}) \mathrm{O}_{2}$ fuels. The process for $\mathrm{ThO}_{2}$ sphere production in a contact plant is well developed and we anticipate no additional research and development costs.

\section{A. 3 REFERENCES}

1. J.B.W. Kanij, A. J. Noothout, and 0. Votocek, "The KEMa U(VI)Process for the Production of $\mathrm{UO}_{2}$ Microspheres," pp. 185-95 in 
Table A1. Ge1-Sphere Conversion Research and Development Estimate ${ }^{a}$ by Year

\begin{tabular}{|c|c|c|c|c|c|c|c|}
\hline \multirow{2}{*}{ Year } & \multirow{2}{*}{$\begin{array}{l}\text { Total } \\
\text { Manpower } \\
\text { Required } \\
\text { (FTE) }\end{array}$} & \multicolumn{2}{|c|}{ Operating Funds } & \multirow{2}{*}{$\begin{array}{l}\text { Operating } \\
\text { Capital } \\
\text { Equipment }\end{array}$} & \multicolumn{2}{|c|}{ Major Projects } & \multirow{2}{*}{ Totals } \\
\hline & & Normal & $\begin{array}{l}\text { Materials } \\
\text { For Others }\end{array}$ & & Equipment & Facility & \\
\hline 1 & 18.8 & 1800 & 450 & 1200 & 300 & & 3750 \\
\hline 2 & 30.2 & 3225 & 400 & 850 & 600 & & 5075 \\
\hline 3 & 27.7 & 2925 & 400 & & 1200 & & 4525 \\
\hline 4 & 25.4 & 2650 & 400 & & 1100 & 600 & 4750 \\
\hline 5 & 36.3 & 4050 & 300 & & 800 & 900 & 6150 \\
\hline 6 & 26.9 & 3025 & 200 & 100 & 1000 & 1200 & 5525 \\
\hline 7 & 25.6 & 2825 & 250 & 100 & 1200 & 1500 & 5875 \\
\hline 8 & 25.0 & 2800 & 200 & & 1000 & 700 & 4700 \\
\hline 9 & 27.1 & 3000 & 250 & & 600 & & 3850 \\
\hline 10 & 32.9 & 3500 & 450 & & & & 3950 \\
\hline 11 & 26.7 & 3000 & 200 & & & & 3200 \\
\hline 12 & 29.2 & 3000 & 500 & & & & 3500 \\
\hline 13 & 10.4 & 1000 & 250 & & & & 1250 \\
\hline 14 & 10.8 & 1000 & 300 & & & & 1200 \\
\hline 15 & 10.8 & 1000 & 300 & & & & 1300 \\
\hline 16 & 11.7 & 1000 & 400 & & & & 1400 \\
\hline
\end{tabular}

astimate in thousands of 1978 dollars.

$b_{\mathrm{FTE}}=$ full-time equivalent in person years. 
Sol-Gel Processes for Fuel Fabrication, IAEA-161, International Atomic Energy Agency, Vienna, Austria, 1974.

2. Battelle Pacific Northwest Laboratory, The Technical Program Plan for the Department fo Energy's Fuel Refabrication and Development Program (in preparation).

3. P. A. Haas et al., Chemical Flowsheet Conditions for Preparing Urania Spheres by Internal Gelation, ORNL-6850 (in press).

4. D. F. Williams et al., Design and Operating Procedures of an Interim Facility for Preparing Kilogram Quantities fo $\mathrm{UO}_{2}$ Spheres by Internal Gelation, ORNL/TM-6950 (in press). 
ORNL/TM-6924

Distribution

Categories UC-77;

$\mathrm{UC}-79 \mathrm{~b},-\mathrm{c}$; UC-83

\section{INTERNAL DISTRIBUTION}

\begin{tabular}{|c|c|}
\hline $1-2$. & Central Research Library \\
\hline 3. & Document Reference Section \\
\hline $4-5$. & Laboratory Records Department \\
\hline 6 . & Laboratory Records, ORNL RC \\
\hline 7 . & ORNL Patent Section \\
\hline 8 . & E. J. Allen \\
\hline 9. & W. J. Armento \\
\hline 10. & J. M. Babcock \\
\hline 11 . & R. L. Beatty \\
\hline 12 . & J. M. Begovich \\
\hline 13. & A. J. Caputo \\
\hline 14. & J. A. Carpenter, Jr. \\
\hline 15. & W. L. Carter \\
\hline 16. & R. G. Donne11y \\
\hline 17. & L. C. Emerson \\
\hline 18. & G. F. Flanagan \\
\hline 19. & R. W. Glass \\
\hline 20. & F. E. Harrington \\
\hline 21 . & P. A. Haas \\
\hline 22 . & M. R. Hayns \\
\hline 23. & C. C. Haws \\
\hline 24. & R. E. Helms \\
\hline $25-27$. & M. R. Hi 11 \\
\hline 28 . & F. J. Homan \\
\hline 29. & J. A. Horak \\
\hline 30 . & D. R. Johns on \\
\hline $31-35$. & R. R. Judkins \\
\hline 36. & P. R. Kasten \\
\hline 37 . & W. J. Lackey \\
\hline 38. & R. E. Leuze \\
\hline
\end{tabular}

39. K. H. Lin

40. M. H. Lloyd

41. E. L. Long, Jr.

42. J. E. Mack

43. S. R. McNeany

44. R. E. Norman

45. K. J. Notz

46-55. A. R. O1sen

56. A. E. Pasto

57. A. D. Ryon

58. T. F. Scanlan

59. J. E. Selle

60. R. D. Spence

61. I. Spiewak

62. D. P. Stinton

63 R. R. Suchome1

64. V. J. Tennery

65. S. M. Tiegs

66. J. S. Vavruska

67. S. K. What ley

68. L. C. Williams

69. B. A. Wor ley

70. R. A. Wymer

71. R. W. Balluffi (Consultant)

72. A. L. Bement, Jr. (Consultant)

73. W. R. Hibbard, Jr. (Consultant)

74. E. H. Kottcamp, Jr. (Consultant)

75. M. J. Mayfield (Consultant)

76. J. T. Stringer (Consultant)

EXTERNAL DISTRIBUTION

77. DOE CHICAGO OPERATIONS OFFICE, 9800 S. Cass Ave., Argonne, IL 60439 Manager

78-79. DOE DIVISION OF NUCLEAR POWER DEVELOPMENT, Washington, DC 20545 
80-81. DOE DIVISION OF REACTOR RESEARCH AND TECHNOLOGY, Washington, DC 20545 Director

82. DOE FAST FLUX TEST FACILITY PROJECT OFFICE, P.O. Box 550, Richland, WA 99352

Director

83. FUEL REFABRICATION AND DEVELOPMENT PROGRAM OFFICE, Battelle Pacific Northwest Laboratories, P.0. Box 999, Richland, WA 99352

84. DOE RICHLAND OPERATIONS OFFICE, P.O. BOX 550, Richland, WA 99352 Manager

85. SAN-DEVELOPMENT, SAN DIEGO AREA OFFICE, P.0. Box 81325, San Diego, CA 92138

Senior Program Coordinator

86. DOE SAN FRANCISCO OPERATIONS OFFICE, 1333 Broadway, We11s Fargo Building, Oakland CA 94612

Manager

87. DOE OAK RIDGE OPERATIONS OFFICE, P.O. Box E, Oak Ridge, TN 37830 Assistant Manager, Energy Research and Development

88-444. DOE TECHNICAL INFORMATION CENTER, P.0. Box 62, Oak Ridge, TN 347830 For distribution as shown in TID-4500 Distribution Category, UC-77 (Gas-Cooled Reactor Technology) UC-79b (LMFBR - Fuels and Materials Engineering and Development) UC-79c (LMFBR - Fuel Recycle) UC-83 (Nuclear Converter Reactor Fuel Cycle Technology) 